\title{
LOCATING OPTIMAL WATER QUALITY MONITORING LOCATIONS USING DEMAND COVERAGE INDEX METHOD
}

\author{
A Thesis \\ presented to \\ the Faculty of California Polytechnic State University, \\ San Luis Obispo \\ In Partial Fulfillment \\ of the Requirements for the Degree \\ Master of Science in Civil and Environmental Engineering \\ by \\ Jeffrey Scott Brake \\ June 2015
}


(C)2015

Jeffrey Scott Brake

ALL RIGHTS RESERVED 
TITLE:

AUTHOR:

DATE SUBMITTED:

COMMITTEE CHAIR:

COMMITTEE MEMBER:

COMMITTEE MEMBER:
Locating Optimal Water Quality Monitoring Locations Using Demand Coverage Index Method

Jeffrey Scott Brake

June 2015

Shikha Rahman, Ph.D.

Associate Professor of Civil and Environmental Engineering

Misgana Muleta, Ph.D., P.E.

Associate Professor of Civil and Environmental Engineering

Rebekah Oulton, Ph.D., P.E.

Assistant Professor of Civil and Environmental

Engineering 


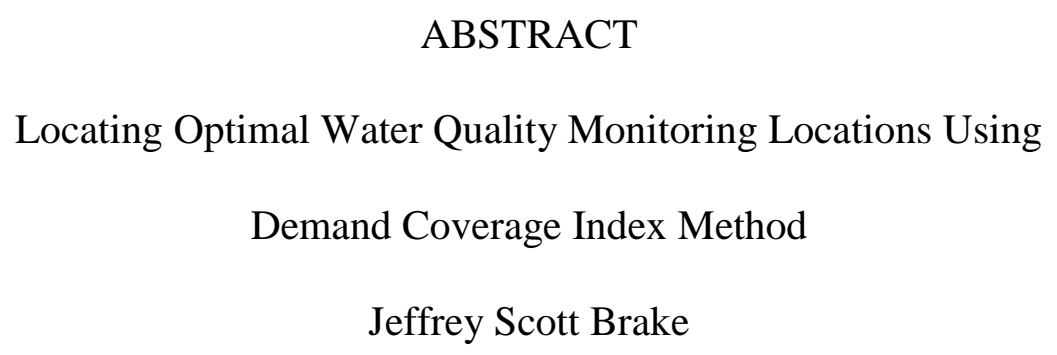

Water quality regulations are always expanding especially in the field of water quality monitoring; however, threats to our water distribution systems still remain. Components of water distribution systems are susceptible to intentional and accidental contamination; therefore, they represent highly vulnerable aspects of our infrastructure.

An analysis was performed on a city in California with a population of 30,000 to 40,000 residents. The analysis is performed to determine the optimal locations of monitoring stations throughout the water distribution system. The method presented by Liu and colleagues (Liu et al, 2012) selects the optimal monitoring locations for the virtual California city using the Demand Coverage Index (DCI) method. In order to study small scale systems which are typically more vulnerable to tampering, the method attempts to use the virtual city to show the effectiveness of the DCI method and how it can be implemented on smaller water distribution systems (WDS).

The analysis results lay out a number of monitoring stations that should be used to prevent a large scale contamination event from occurring. The number of monitoring stations will vary depending on funding for water infrastructure and coverage requirements. The results represent an outline for improving the effectiveness of the monitoring capabilities in the WDS. The monitoring stations increase the resilience of the WDS from potential terrorist sabotage and mitigate potential outbreaks due to microorganisms, pipeline leaks, or hazardous chemicals entering the WDS. 


\section{ACKNOWLEDGMENTS}

I would like to thank all the teachers and staff at Cal Poly for their dedication and willingness to help. The teachers are the heart of Cal Poly and I cannot thank them enough for their support. I'd like to thank my committee members for taking time to guide me through the thesis process and especially my thesis advisor, Shikha Rahman, for always being able to help me. Dr. Rahman has been very influential in my college life due to the many classes and projects that we have been involved with.

I also want to thank my fellow students in the civil and environmental engineering department for always being willing to stay up late to work on projects or study for finals.

Finally, I'd like to thank my family for always being supportive in my life. Your guys unrelenting encouragements have gone so far in helping me accomplish my goals. 


\section{TABLE OF CONTENTS}

Page

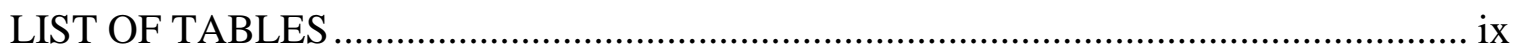

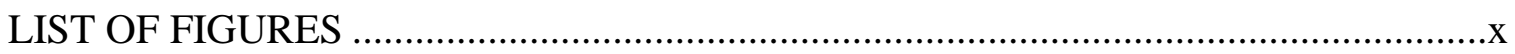

ACRONYMS AND ABBREVIATIONS ….......................................................... xiii

\section{CHAPTER}

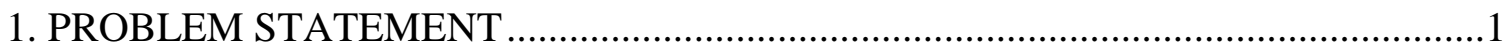

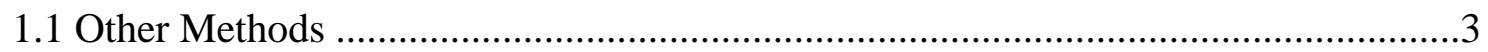

2. WATER SYSTEM EXAMINATION ….............................................................

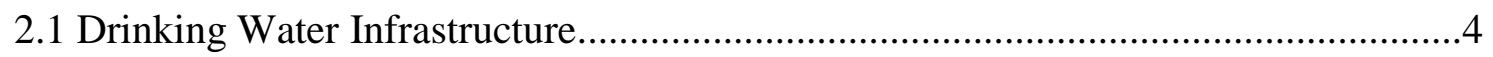

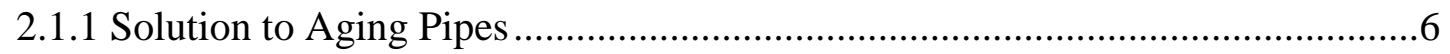

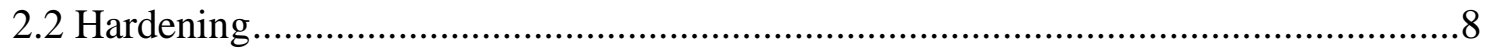

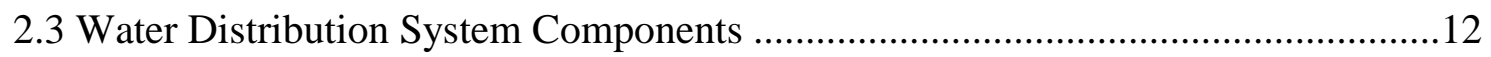

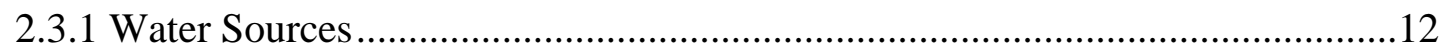

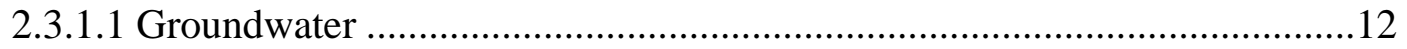

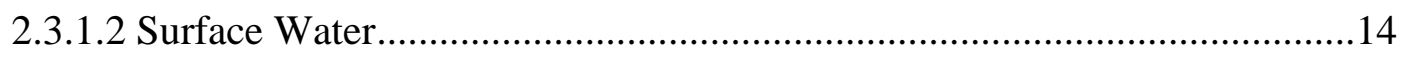

2.3.1.3 Groundwater Under the Direct Influence of Surface Water (GWUDI) ......15

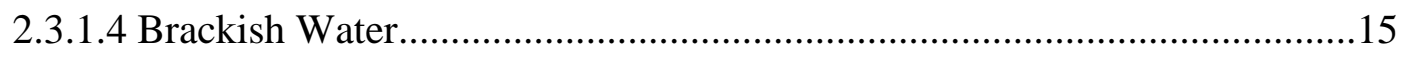

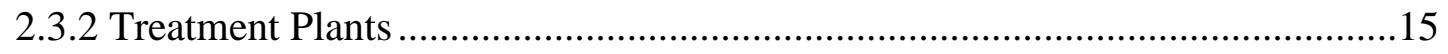

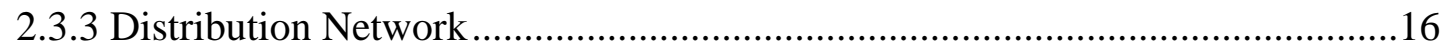

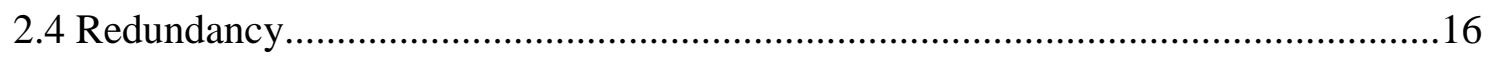

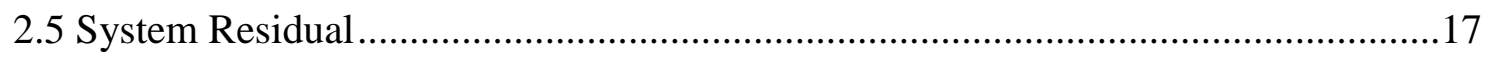

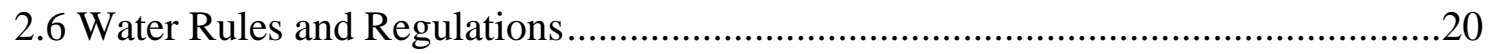

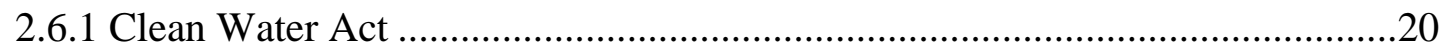

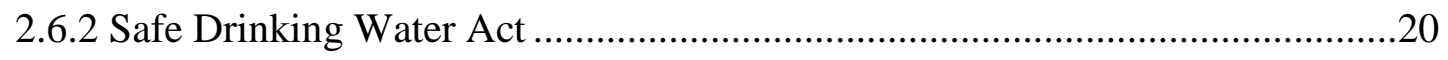

2.6.3 Surface Water Treatment Rules...............................................................21

2.6.3.1 Surface Water Treatment Rule of 1989 .................................................21

2.6.3.2 Interim Enhanced Surface Water Treatment Rule of 1998.......................22

2.6.3.3 Filter Backwash Recycling Rule of 2001 ..............................................22

2.6.3.4 Long Term 1 Enhanced Surface Water Treatment Rule of 2002 ..............23 
2.6.3.5. Long Term 2 Enhanced Surface Water Treatment Rule of 2006 .23

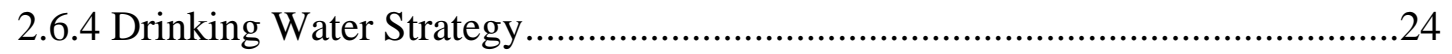

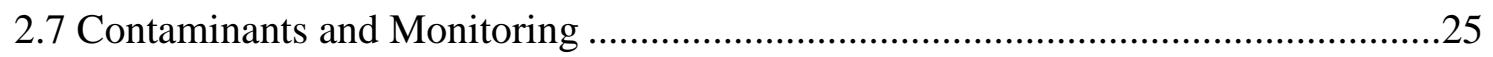

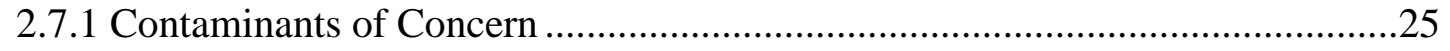

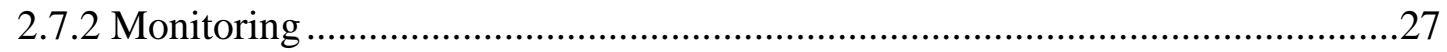

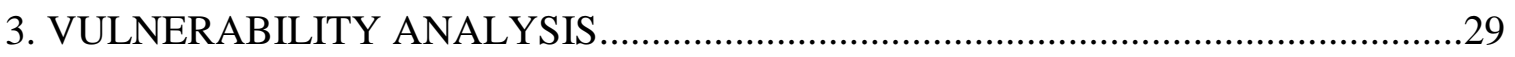

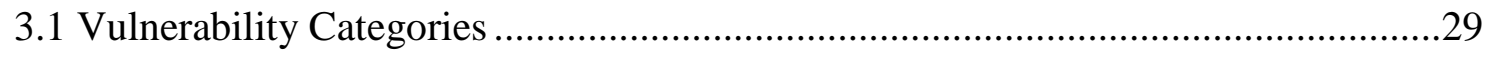

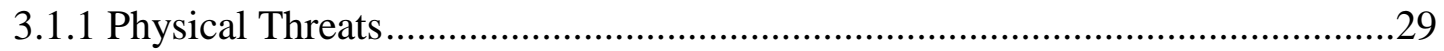

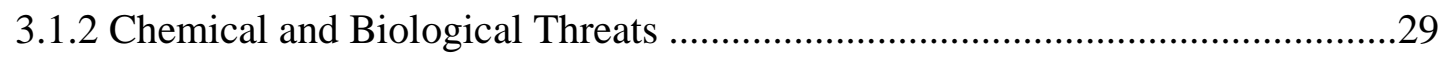

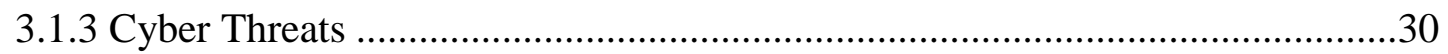

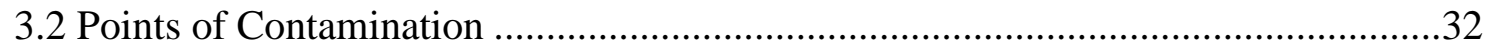

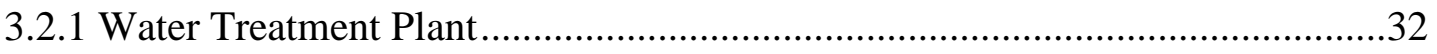

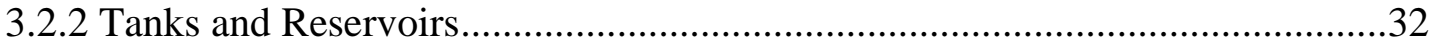

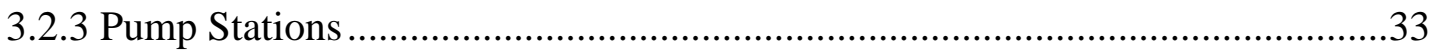

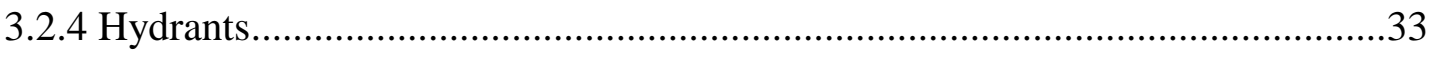

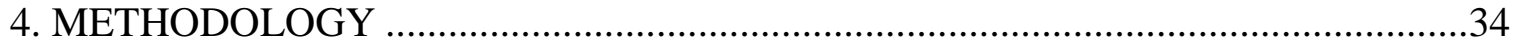

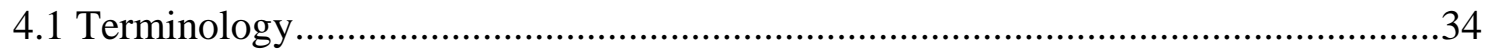

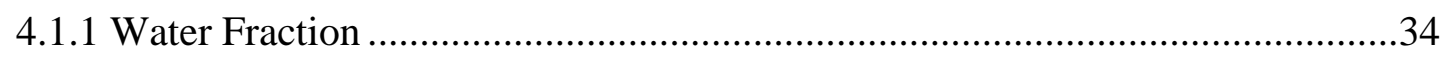

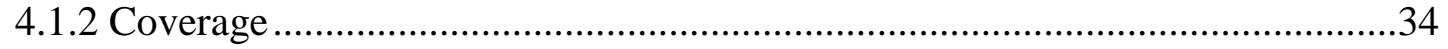

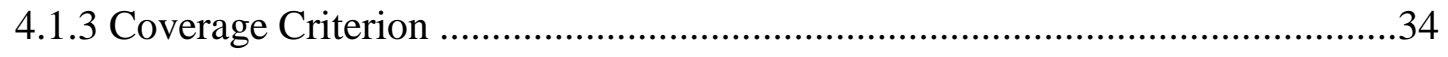

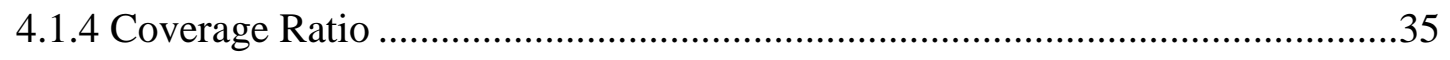

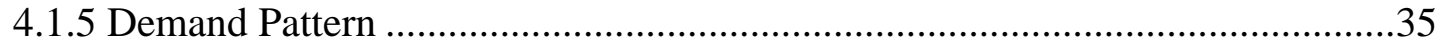

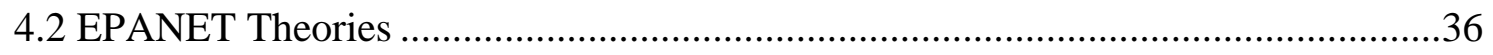

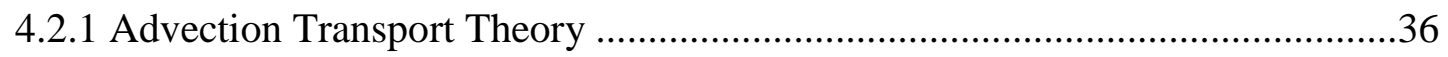

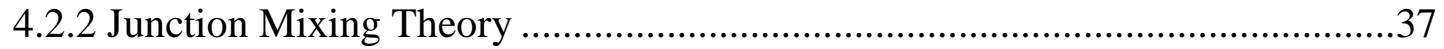

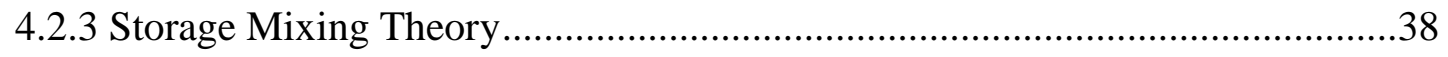

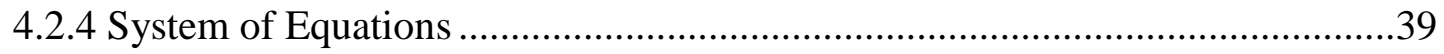

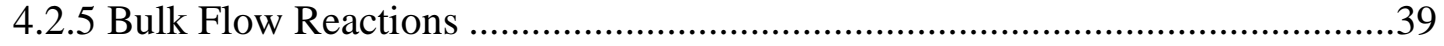

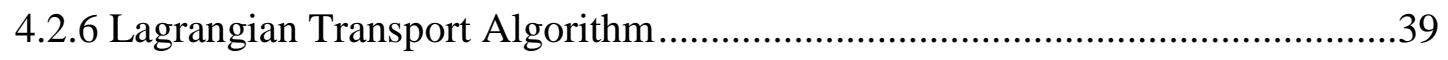

4.3 Number of Optimal Monitoring Stations .....................................................40

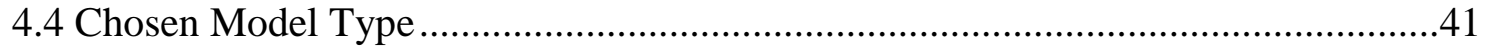




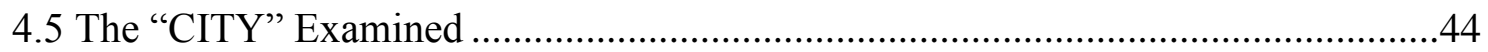

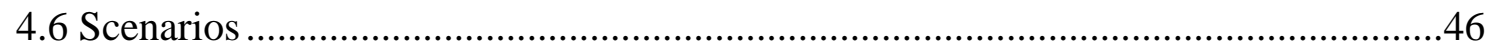

4.6.1 Scenario 1: Steady State with Max Daily Demand and $\mathrm{Cc}=50 \%$.......................46

4.6.2 Scenario 2-7: Extended Period Simulation with $\mathrm{Cc}=50 \%$ and Pattern 2.0,

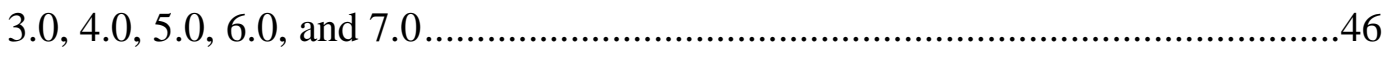

4.6.3 Scenario 8: Max Daily Demand and Pattern 2.0 with $\mathrm{Cc}=25 \%$, 50\%, and $75 \%$

4.6.4 Scenario 9: A Coverage Ratio of 95\% is Desired Using Pattern 2.0..................47

4.6.5 Scenario 10: Demand Coverage (DC) vs Demand Coverage Index (DCI)

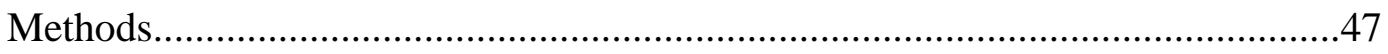

4.7 Summarization of Demand Coverage Index Methodology …...................................48

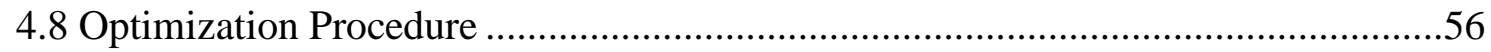

4.9 Exporting WaterCAD Results to Excel ……………............................................59

4.10 Summary and Discussion of Results..................................................................63

4.10.1 Scenario 1: Max Daily Demand .......................................................................63

4.10.2 Scenario 2-7 Demand Pattern 2.0, 3.0, 4.0, 5.0, 6.0, \& 7.0 …........................63

4.10.3 Scenario 8: Pattern 2.0 with $\mathrm{Cc}=25 \%, 50 \%$, and $75 \% \ldots \ldots \ldots \ldots \ldots \ldots \ldots \ldots \ldots \ldots \ldots \ldots . . . . . .13$

4.10.4 Scenario 9: 95\% Coverage Ratio...................................................................75

4.10.5 Scenario 10: Demand Coverage vs Demand Coverage Index ...........................79

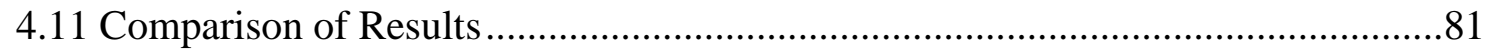

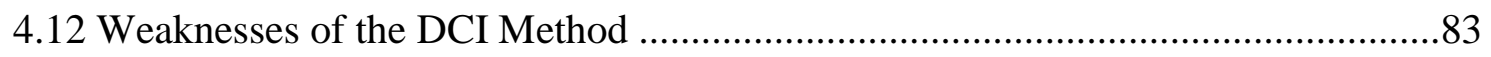

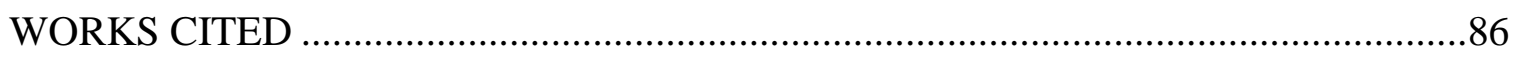

APPENDICES

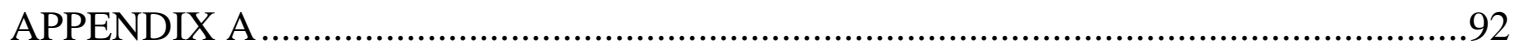

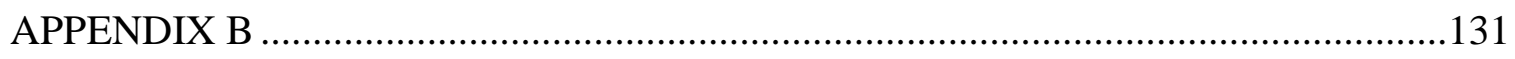




\section{LIST OF TABLES}

Table

Page

Table 1: Regulations for Secondary Disinfectant Residual (HDR) ................................19

Table 2: Abbreviated Version of Microorganisms of Concern (Drinking Water).............26

Table 3: Pollutants Associated with Certain Sources (Chapter 5) ...................................28

Table 4: Booster Schedule for Tanks.......................................................................44

Table 5: Water Fraction Matrix For Pattern 2.0 at $\mathrm{Hr} 13$.............................................52

Table 6: Coverage of Pattern 2.0 at Hr 13 ..................................................................52

Table 7: Demand Coverage Matrix for Pattern 2.0 at $\mathrm{Hr} 13$........................................53

Table 8: Demand Coverage Matrix for Pattern 2.0.........................................................53

Table 9: Results Table for Pattern 2.0 ..........................................................................54

Table 10: Example of Demand Coverage and Demand Coverage Index Methods ............55

Table 11: Comparison of Similarly Covered Source Nodes..........................................57

Table 12: Final Output for Optimization Procedure for Pattern 2.0 ...............................58

Table 13: WaterCAD Output for Trace \% and Demand at Hour 12 ...............................60

Table 14: WaterCAD Output in Excel (Pre-Macro) ......................................................61

Table 15: Water Fraction Matrix for Hr 13 (Post-Macro) ................................................62

Table 16: Summary of Results Using the DCI Method and Max Daily Demand

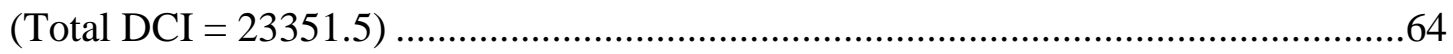

Table 17: Summary of Results Using the DCI Method and Demand Pattern 2.0

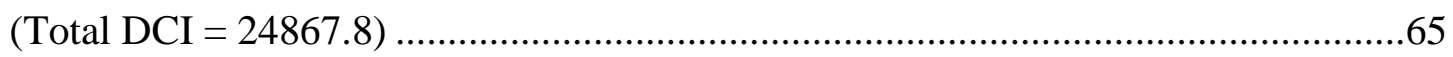

Table 18: Summary of Results Using the DCI Method and Demand Pattern 3.0

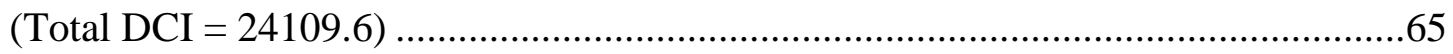

Table 19: Summary of Results Using the DCI Method and Demand Pattern 4.0 $($ Total DCI $=11582.7)$

Table 20: Summary of Results Using the DCI Method and Demand Pattern 5.0 (Total DCI $=10591.4)$

Table 21: Summary of Results Using the DCI Method and Demand Pattern 6.0 (Total DCI $=9114.5)$

Table 22: Summary of Results Using the DCI Method and Demand Pattern 7.0 (Total DCI $=9654.5)$

Table 23: Results of Changing Coverage Criterion

Table 24: Results for Additional MS's in Order to Achieve a 95\% Coverage Ratio (Total DCI $=24867.8$ )

Table 25: Results Using The Demand Coverage Method For Max Daily Demand Pattern .79

Table 26: Results Using The Demand Coverage Method For Demand Pattern 2.0 


\section{LIST OF FIGURES}

Figure

Page

Figure 1: EPA Estimate of 20-yr Water Investment to Update WDS (Drinking Water, 2013)

Figure 2: State Revolving Loan Fund for 2008-2012 (Drinking Water, 2013) ..................5

Figure 3: Cross Section of Aqua-Pipe (Home, 2015) ..................................................6

Figure 4: Impact on Residents due to Installation (Bright, 2010)...................................

Figure 5: Before and After Rehabilitation (Home, 2015) ..............................................

Figure 6: Installation Process (Bright, 2010) ............................................................

Figure 7: Sketch of Unconfined Aquifer with Perched Water Tables (Todd et al, 2005).13

Figure 8: Sketch of Confined and Unconfined Aquifers (Todd et al, 2005) .....................13

Figure 9: Sketch of Semiconfined, or Leaky Aquifer (Todd et al, 2005) .........................13

Figure 10: Schematic of Branched Network.................................................................. 17

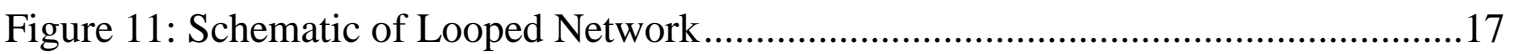

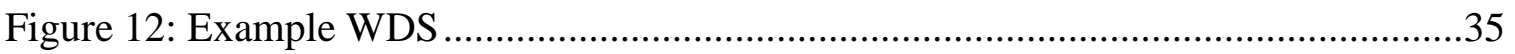

Figure 13: Max Daily Demand Pattern ...................................................................... 41

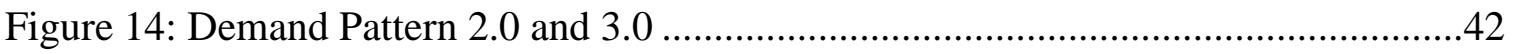

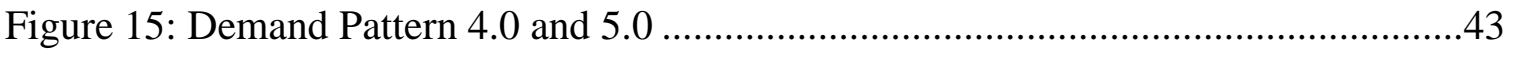

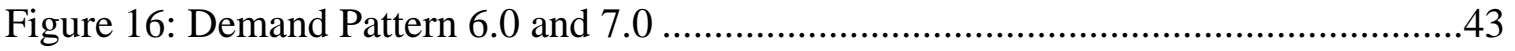

Figure 17: Water Distribution System of "the CITY" .................................................45

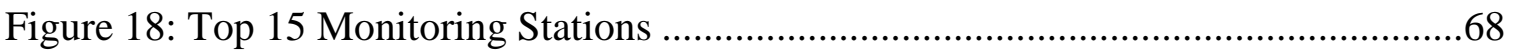

Figure 19: Monitoring Station 1-5 with Corresponding Coverages ...............................69

Figure 20: Monitoring Station 6-10 with Corresponding Coverages ...............................70

Figure 21: Monitoring Station 11-15 with Corresponding Coverages ..............................71

Figure 22: Top 15 Monitoring Stations with Corresponding Coverages..........................72

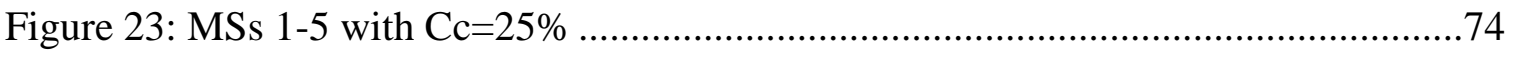

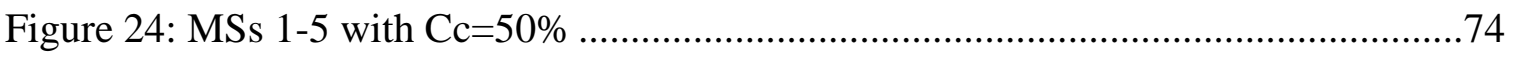

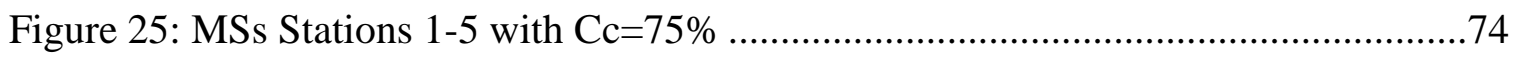

Figure 26: MS 16-20 with Corresponding Coverages .................................................. 76

Figure 27: MS 21-22 with Corresponding Coverages .................................................77

Figure 28: Top 22 Monitoring Stations with Corresponding Coverages..........................78

Figure 29: Areas of Significance Determined by Laurence (Johnson, 2012) ....................82

Figure 30: Locations of the Pressure Release Valves (PRVs) Connecting to the Main

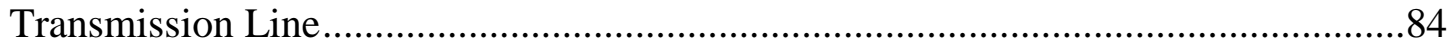

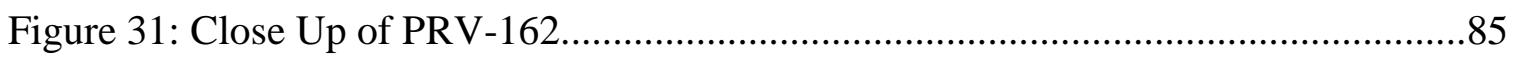

Figure 32: Monitoring Station 1-5 with Corresponding Coverages for Max Daily

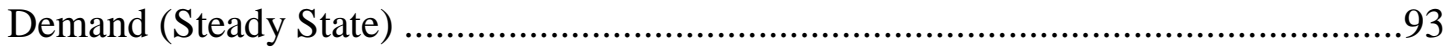

Figure 33: Monitoring Station 6-10 with Corresponding Coverages for Max Daily

Demand (Steady State) 
Figure 34: Monitoring Station 11-15 with Corresponding Coverages for Max Daily

Demand (Steady State)

Figure 35: Top 15 Monitoring Stations with Corresponding Coverages for Max Daily

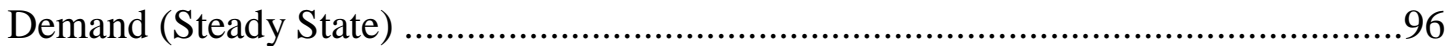

Figure 36: Top 15 Monitoring Stations for Max Daily Demand (Steady State) ...............97

Figure 37: Monitoring Station 1-5 with Corresponding Coverages for Demand

Pattern 2.0 (Unsteady State) .98

Figure 38: Monitoring Station 6-10 with Corresponding Coverages for Demand

Pattern 2.0 (Unsteady State)

Figure 39: Monitoring Station 11-15 with Corresponding Coverages for Demand

Pattern 2.0 (Unsteady State) 100

Figure 40: Top 15 Monitoring Stations with Corresponding Coverages for Demand

Pattern 2.0 (Unsteady State)

Figure 41: Top 15 Monitoring Stations for Demand Pattern 2.0 (Unsteady State) .........102

Figure 42: Monitoring Station 16-20 with Corresponding Coverages for Demand

Pattern 2.0 (Unsteady State)

Figure 43: Monitoring Station 21-22 with Corresponding Coverages for Demand

Pattern 2.0 (Unsteady State)

Figure 44: Top 22 Monitoring Stations with Corresponding Coverages for Demand

Pattern 2.0 (Unsteady State)

Figure 45: Monitoring Station 1-5 with Corresponding Coverages for Demand

Pattern 3.0 (Unsteady State)

Figure 46: Monitoring Station 6-10 with Corresponding Coverages for Demand

Pattern 3.0 (Unsteady State)

Figure 47: Monitoring Station 11-15 with Corresponding Coverages for Demand

Pattern 3.0 (Unsteady State)

Figure 48: Top 15 Monitoring Stations with Corresponding Coverages for Demand

Pattern 3.0 (Unsteady State)

Figure 49: Top 15 Monitoring Stations for Demand Pattern 3.0 (Unsteady State) .........110

Figure 50: Monitoring Station 1-5 with Corresponding Coverages for Demand

Pattern 4.0 (Unsteady State)

Figure 51: Monitoring Station 6-10 with Corresponding Coverages for Demand

Pattern 4.0 (Unsteady State)

Figure 52: Monitoring Station 11-15 with Corresponding Coverages for Demand

Pattern 4.0 (Unsteady State)

Figure 53: Top 15 Monitoring Stations with Corresponding Coverages for Demand

Pattern 4.0 (Unsteady State)

Figure 54: Top 15 Monitoring Stations for Demand Pattern 4.0 (Unsteady State) .........115 
Figure 55: Monitoring Station 1-5 with Corresponding Coverages for Demand

Pattern 5.0 (Unsteady State)

Figure 56: Monitoring Station 6-10 with Corresponding Coverages for Demand

Pattern 5.0 (Unsteady State)

Figure 57: Monitoring Station 11-15 with Corresponding Coverages for Demand

Pattern 5.0 (Unsteady State) 118

Figure 58: Top 15 Monitoring Stations with Corresponding Coverages for Demand

Pattern 5.0 (Unsteady State)

Figure 59: Top 15 Monitoring Stations for Demand Pattern 5.0 (Unsteady State) .........120

Figure 60: Monitoring Station 1-5 with Corresponding Coverages for Demand

Pattern 6.0 (Unsteady State)

Figure 61: Monitoring Station 6-10 with Corresponding Coverages for Demand

Pattern 6.0 (Unsteady State)

Figure 62: Monitoring Station 11-15 with Corresponding Coverages for Demand

Pattern 6.0 (Unsteady State)

Figure 63: Top 15 Monitoring Stations with Corresponding Coverages for Demand

Pattern 6.0 (Unsteady State)

Figure 64: Top 15 Monitoring Stations for Demand Pattern 6.0 (Unsteady State) .........125

Figure 65: Monitoring Station 1-5 with Corresponding Coverages for Demand

Pattern 7.0 (Unsteady State) 126

Figure 66: Monitoring Station 6-10 with Corresponding Coverages for Demand

Pattern 7.0 (Unsteady State)

Figure 67: Monitoring Station 11-15 with Corresponding Coverages for Demand

Pattern 7.0 (Unsteady State) 128

Figure 68: Top 15 Monitoring Stations with Corresponding Coverages for Demand

Pattern 7.0 (Unsteady State)

Figure 69: Top 15 Monitoring Stations for Demand Pattern 7.0 (Unsteady State) 130 


\section{ACRONYMS AND ABBREVIATIONS}

\begin{tabular}{|c|c|}
\hline ADCR & Accumulation of Demand Coverage Ranking \\
\hline AOP & Advanced Oxidation Process \\
\hline ASCE & American Society of Civil Engineers \\
\hline AWWA & American Water Works Association \\
\hline $\mathrm{Cc}$ & Coverage Criterion \\
\hline $\mathrm{cVOC}$ & Carcinogenic Volatile Organic Compound \\
\hline CWA & Clean Water Act \\
\hline DBP & Disinfection Byproducts \\
\hline DBPR & Disinfection Byproducts Rule \\
\hline DC & Demand Coverage \\
\hline DCI & Demand Coverage Index \\
\hline DWS & Drinking Water Strategy \\
\hline EPA & Environmental Protection Agency \\
\hline FBI & Federal Bureau of Investigations \\
\hline FBRR & Filter Backwash Recycling Rule \\
\hline GPM & Gallons per Minute \\
\hline HAA & Haloacetic Acid \\
\hline IESWTR & Interim Enhanced Surface Water Treatment Rule \\
\hline ISAC & Information Sharing and Analysis Center \\
\hline GWUDI & Groundwater Under the Direct Influence of surface water \\
\hline LT1 & Long Term 1 enhanced surface water treatment rule \\
\hline LT2 & Long Term 2 enhanced surface water treatment rule \\
\hline MCL & Maximum Contaminant Level \\
\hline MCLG & Maximum Contaminant Level Goal \\
\hline MRDL & Maximum Residual Disinfectant Level \\
\hline MS & Monitoring Station \\
\hline NCDCR & Normalized Cumulative Demand Coverage Ranking \\
\hline NPDES & National Pollutant Discharge Elimination System \\
\hline PRV & Pressure Reducing Valve \\
\hline SDWA & Safe Drinking Water Act \\
\hline SRF & State Revolving Loan Fund \\
\hline SWTR & Surface Water Treatment Rule \\
\hline TCR & Total Coliform Rule \\
\hline TDC & Total Demand Coverage \\
\hline THM & Trihalomethanes \\
\hline TOC & Total Organic Carbon \\
\hline TTHM & Total Trihalomethanes \\
\hline WDS & Water Distribution System \\
\hline WIFIA & Water Infrastructure Finance Innovations Authority \\
\hline UV & Ultraviolet \\
\hline UIC & Underground Injection Control \\
\hline
\end{tabular}




\section{PROBLEM STATEMENT}

Water quality monitoring is a constant concern in water distribution systems, especially with increasing threats of terrorism and a crumbling water infrastructure. This is made obvious with the Homeland Security Presidential Directive 7 and the Bioterrorism Preparedness Act of 2002 which heightened alertness about protecting critical water infrastructure and the need to harden the overall system. Quality of intake water and application of treatment technologies are difficult aspects of distribution systems, but when contamination and the threat of a terrorist attack are possible scenarios, water quality monitoring throughout the system is essential. Security is also vital but difficult to maintain because of the vast areas these systems cover and how vital clean drinking water is. Monitoring is not possible everywhere due to limited resources; hence optimal, or efficient, locations of sensors and monitoring stations are necessary to screen the water for contaminations and discrepancies.

Data concerning water distribution networks, including the population a system serves, physical characteristics, and security, are extremely difficult to obtain due to obvious security concerns. However, Brumbelow (Brumbelow et al, 2007) proposed using a virtual city to analyze and obtain realistic water distribution data. This virtual city is an optimal solution because realistic world data can be used for various threat or disaster scenarios to create security or relief plans.

For the current study, a water distribution system was obtained for a 30,000 to 40,000 resident community. This is a real system in California but for protection of the operators and users, the community will only be referred to as "the CITY" in this study. This system was modelled and analyzed in a previous Master of Science thesis (Johnson, 
2012), where a heuristic method was used to solve for the optimal locations for monitoring stations. The method counted the number of contamination detections a particular node obtained when the storage tanks were contaminated. The nodes with the highest number of detections are considered the optimal locations. Another, more complex, method presented by Liu (Liu et al., 2012) will be used in this study to analyze the WDS to compare results and discuss the validity and accuracy of both methods.

The method used in this study is called the Demand Coverage Index (DCI) method and it differs from the heuristic method since it takes into consideration the impact of the temporal distribution of the system as the demand is changing throughout a given day. The method begins with a steady state analysis of the WDS. A trace analysis is then then conducted to determine the fraction of water that contributes to the water distribution system and a water fraction matrix is created. Using a coverage criterion, a coverage matrix and then a demand coverage matrix are created to determine the demand coverage index at each node. Finally, maximizing the demand coverage index gives the most optimal locations for the monitoring stations. The same analysis is then performed for several extended period simulations to represent a more realistic analysis of the WDS. 


\subsection{Other Methods}

The heuristic method used in the previous study on the same WDS was introduced by Chastain (Chastain, 2004). The method counts the times a node detects a contamination event when a particular source node is injected with contaminant. The previous thesis (Johnson, 2012) used the tanks as injection sites to determine the locations of the monitoring stations.

Another method that Liu and colleagues discuss is the Demand Coverage (DC) method presented by Lee and Deininger (Lee et al., 1992). This method is based on the notion that sampling at an upstream location will give information about the water at a downstream location. Then, it maximizes the coverage of water with the minimum number of monitoring stations. Lee and Deininger (Lee et al., 1992) optimize this problem using an integer programming method but a variety of methods can be used. For example, Kumar et al (Kumar et al., 1997), used a heuristic based algorithm, Al-Zahrani and Moied (Al-Zahrani et al., 2001) used a genetic algorithm, and Tryby and Uber (Tryby et al., 2001) used a mixed integer linear programming model to use water age to determine how representative a sample may be. All these alternatives are derived from the Demand Coverage method.

The DC method differs from the DCI method because it ignores how the different time periods will affect the representativeness of a node. This could lead to problems calculating the demand coverage and therefore change the location of the monitoring stations. An example of how these two methods differ can be seen in Table 10 in the Methodology section. 


\section{WATER SYSTEM EXAMINATION}

\subsection{Drinking Water Infrastructure}

The problem of monitoring the water distribution system is compounded by the deteriorating water infrastructure. The water systems are declining at an alarming rate where frequently the pipes are over 100 years old and significantly past their design lives. According to the 2013 Report Card for Drinking Water (Drinking Water, 2013) by the American Society of Civil Engineers (ASCE), the drinking water infrastructure receives a $\mathrm{D}+$ grade. This rating is unacceptable for a first world country that relies heavily on water distribution systems to supply water to citizens. The U.S. has over 170,000 public drinking water systems and 54,000 are community water systems serving over 264 million people. Approximately 240,000 water mains break per year in the U.S. causing major damage and interruption to roadways, structures, fire control, and transportation.

The main reason for the large number of main pipe ruptures is the difficulty in examining the pipes because they are buried underground and it would be financially unrealistic to examine every pipe. Communities are using analysis tools to determine the worst-condition pipes which should be replaced or repaired first. Another reason for the poor infrastructure is the lack of funding and the additional costs due to requirements set forth by regulations such as the Safe Drinking Water Act (SDWA). These regulations force communities to improve their systems while providing insufficient funding to accomplish this. According to the Environmental Protection Agency (EPA), an investment of $\$ 335$ billion would be needed to update and repair our failing infrastructure (Figure 1). This investment is likely to be much higher taking into account population growth especially if the U.S. waits years to take action. 


\begin{tabular}{|c|c|}
\hline SYSTEM SIZE AND TYPE & NEED \\
\hline LARGE COMMUNITY WATER SYSTEMS SERVING 100,000 OR MORE PERSONS & S116.3BILION \\
\hline MEDIUM COMMUNITY WATER SYSTEMS SERVING 3,301 TO 100,000 PERSONS & S145.1BILION \\
\hline SMALL COMMUNITY WATER SYSTEMS SERVING 3,300 AND FEWER PERSONS & S59.4 BIயION \\
\hline NONPROFIT COMMUNITY WATER SYSTEMS & \$4.1B॥யON \\
\hline TOTAL STATE NEEDS & S324.9BILION \\
\hline NATIVE AMERICAN AND ALASKAN NATIVE VILLAGE WATER SYSTEMS & S2.9BILION \\
\hline COSTS ASSOCIATED WITH PROPOSED AND ADOPTED SAFE DRINKING WATER ACT RULES & S7 BILION \\
\hline TOTAL NATIONAL NEEDS & \$334.8BILION \\
\hline
\end{tabular}

Figure 1: EPA Estimate of 20-yr Water Investment to Update WDS (Drinking Water, 2013)

In order to improve the drinking water infrastructure, significant changes will

have to occur. The options presented in the report card by ASCE (Drinking Water, 2013)

are as follows:

1. Increase public knowledge of the actual cost of water. Raising knowledge of the need for water infrastructure and the associated costs will show people that the current water rates are unrealistic for providing clean, reliable water. Higher water rates are required to help improve the drinking water infrastructure.

2. Bolster the State Revolving Loan Fund (SRF) program. This can be done by reauthorizing more federal funding over the coming years. Figure 2 shows funding for 2008-2012.

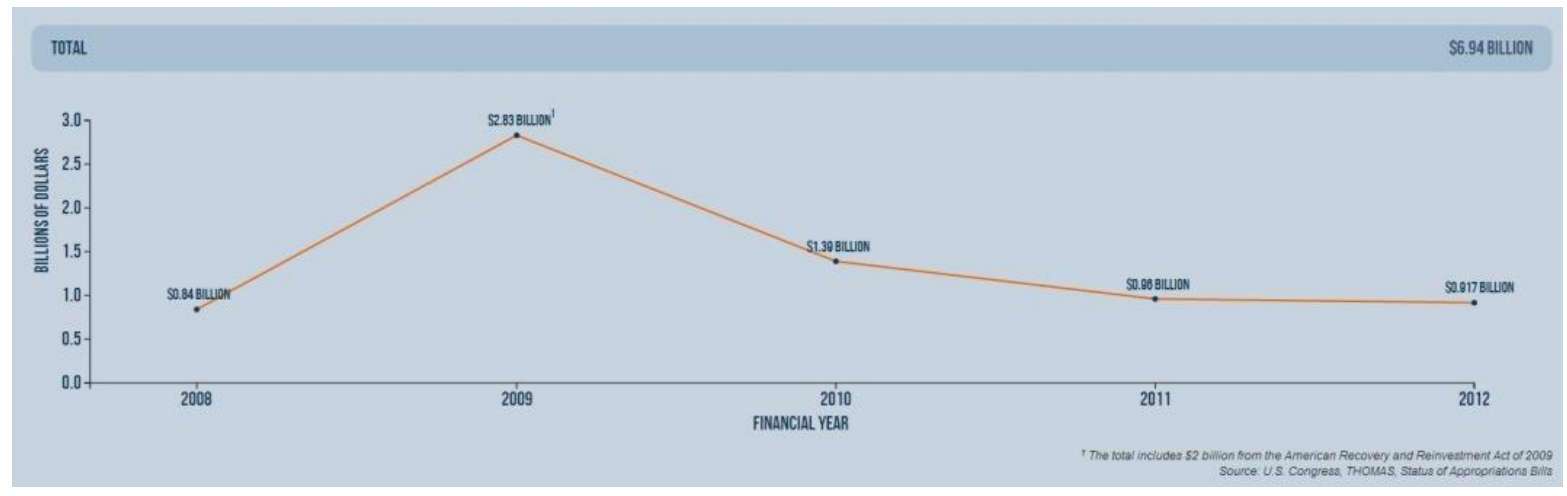

Figure 2: State Revolving Loan Fund for 2008-2012 (Drinking Water, 2013) 
3. Suspend state caps on private activity bonds for water infrastructure. This could bring an estimated \$6-7 billion annually to be used to rebuild and improve the current infrastructure.

\section{Assess the possibility of a Water Infrastructure Finance Innovations Authority} (WIFIA). The WIFIA would use funds loaned from the U.S. Treasury to support water projects. Eventually, the loans would be paid back to WIFIA and then the Treasury. 5. Create a federal Water Infrastructure Trust Fund. The Trust Fund would help finance infrastructure projects under the Clean Water Act (CWA) and SDWA.

\subsubsection{Solution to Aging Pipes}

An innovative solution to the aging pipes is the Aqua-Pipe. The Aqua-Pipe is a trenchless technology used in drinking water systems to reline water main pipes. It is 2040\% less expensive than traditional rehabilitation, causes less impacts to residents because roads do not need to be excavated and repaved (Figure 4), requires no future maintenance, and it can be used under bridges and highways without requiring large excavations. Figure 3 is a cross section of the layers of the Aqua Pipe and Figure 5 shows the final product in place. The new pipes are corrosion resistant and increase the life of the pipe without compromising flow pressure or capacity.

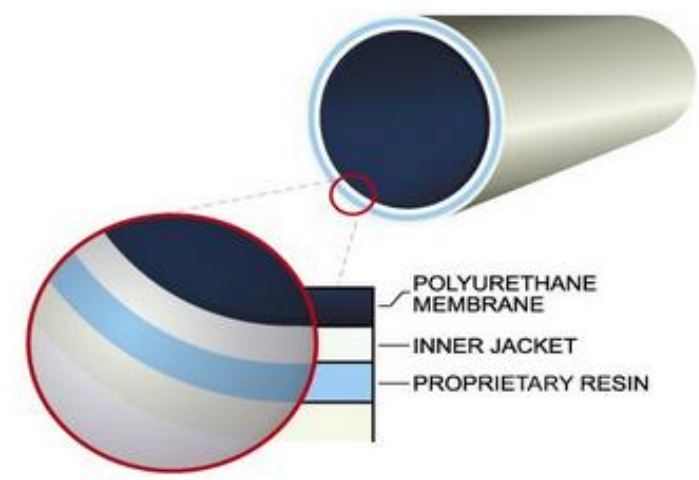

Figure 3: Cross Section of Aqua Pipe (Home, 2015) 

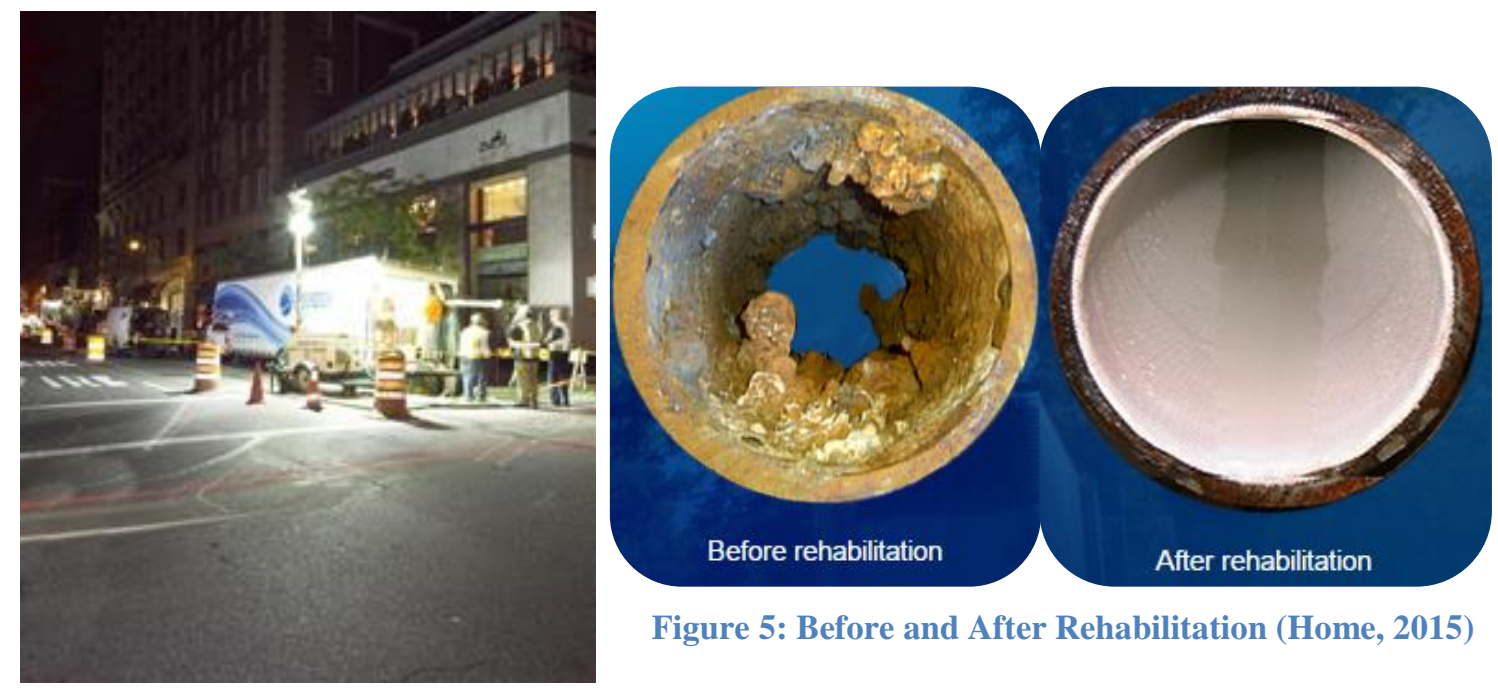

Figure 5: Before and After Rehabilitation (Home, 2015)

Figure 4: Impact on Residents due to Installation (Bright, 2010)

Installing this system is significantly easier to accomplish because access pits are only needed at the ends of the section as opposed to digging up the whole pipeline (Figure 6). The new pipe material is then pulled through the pipe and is cured in place with hot water. This process works along bends and under bridges as well. Figure 5 shows a pair of photos of the pipe before and after rehabilitation. This innovative new technology reduces costs associated with replacing water infrastructure and reduces the time required to fix urgent water mains which if ruptured, can cost huge amounts of money to repair surrounding roads and buildings. The Aqua-Pipe would be an ideal solution to the deteriorating pipe network by helping utility workers fix potential weaknesses in the system and put in place monitoring stations to ensure a steady, reliable water supply for future generations. 


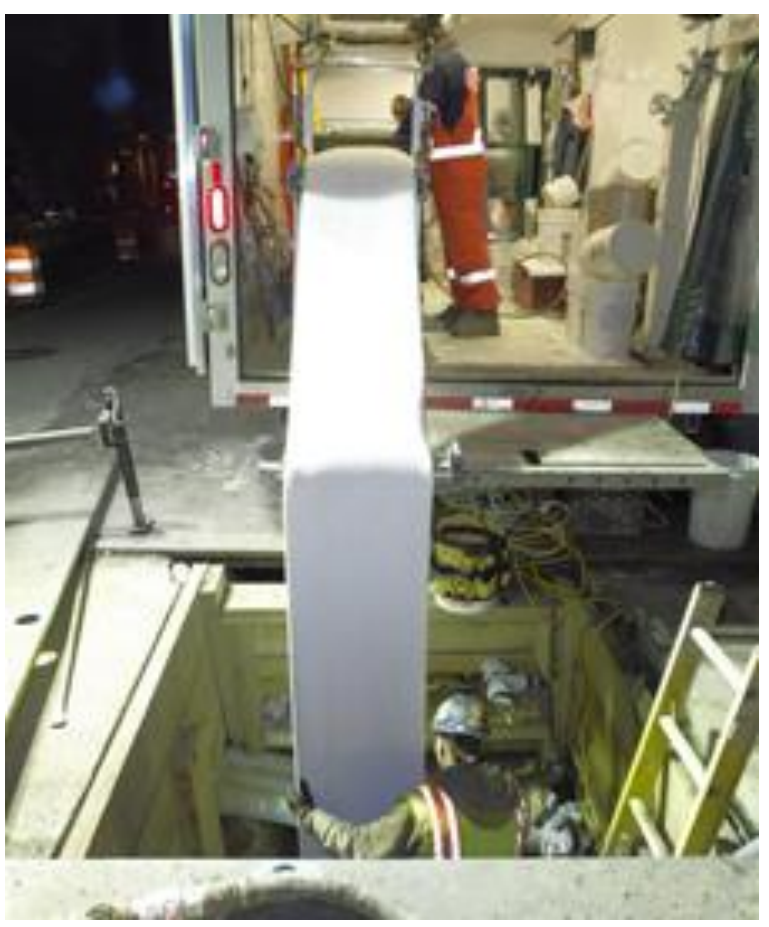

Figure 6: Installation Process (Bright, 2010)

\subsection{Hardening}

Water system hardening is the process of protecting a system by reducing possible weaknesses or vulnerabilities. It continues to be an important aspect of water resources as threats of intentional sabotage or contamination rise, regulations expand to include more contaminants and stricter guidelines, and technology advances. For water distribution systems, hardening means protecting vulnerable locations from tampering (i.e. treatment plants, storage tanks, etc.) and reducing the risk of microorganisms contaminating the water supply.

Updated in 2007, the Key Features to achieve system hardening were developed by the EPA to "enhance resiliency and promote continuity of service, regardless of the exact type of hazard or adverse effect a utility might experience (Water: Key Features, 2014)." The Key features are as follows: 


\section{Integrate protective concepts into organizational culture, leadership, and daily operations.}

Protection must be a daily routine supported by senior leadership who are receptive to employees that may observe suspicious activities or may have concerns about potential problems. Well informed leadership is a key aspect of this feature. Leaders are encouraged to stay up to date with advances in security and threat information while working collaboratively with employees to ensure a safe environment.

\section{Identify and support protective program priorities, resources, and utility-specific measures.}

Continuous focus on protective programs requires resources and investments such as time and effort from managers. Resources should be allocated to the utilities at the most risk and these resources should be used to determine specific protective program needs. Metrics should be used to evaluate performance of the protective programs so adjustments can be made. Self-assessment and progress measurements are vital metrics that should be evaluated regularly.

\section{Employ protocols for detection of contamination.}

An overall contamination warning system is made up of monitoring water quality, sampling and analysis, enhanced security, and monitoring customer complaints. These aspects help to reduce the public health risk associated with potential contamination events. 


\section{Assess risks and review vulnerability assessments.}

Due to the ever changing threats to water systems, utilities should continually update and review their vulnerability assessments in order to stay up to date on potential susceptibilities and possible consequences.

\section{Establish facility and information access controls.}

Restrictions should be made to utilities to limit access to authorized users only and controls should be established to detect unauthorized intrusions by physical and cyber threats. Examples of these controls include fences, motion detectors, security patrol, changing access codes regularly, inventorying keys, maintaining firewalls, and denying remote access to data networks.

\section{Incorporate resiliency concepts into physical infrastructure.}

Utilities should be designed with plans that contribute to overall protection of the utility while also designing for effective daily operations that ensure the safety of workers.

\section{Prepare, test and update emergency response, recovery and business continuity plans.}

The plans should constantly be updated to manage the evolving threats that utilities face. These plans should involve emergency services in the larger community and utilities should test these plans frequently to ensure preparedness of the community in the event of an emergency. 


\section{Form partnerships with peers and interdependent sectors.}

Building relationships with emergency services and managers of critical infrastructure, such as the power sector, will help people work together to manage an emergency effectively with a minimal interruption of service.

\section{Develop and implement internal and external communication strategies.}

Utilities should increase awareness of employees, customers, and the general public about response plans. This is accomplished through regular communications about developing strategies. Websites, social media, and annual reports can be great ways to keep all stakeholders informed.

\section{Monitor incidents and threat level information.}

Systems that analyze threat information should be developed by utilities so proper procedures can be followed based on the threat level. Collaboration with local law enforcement as well as the Federal Bureau of Investigations (FBI) is essential.

The vital characteristics of the Key Features are consistency and flexibility among all utilities, regardless of size, type of source water, treatment capacity, budget, etc. The Key Features will help ensure that all utilities are working toward protecting critical drinking water supplies and that those supplies are monitored to mitigate risks to public health. 


\subsection{Water Distribution System Components}

\subsubsection{Water Sources}

Drinking water sources are provided by public utilities, commercial entities, communities, or individuals and are supplied through a distribution system consisting of pumps and pipes. These water sources can be categorized into groundwater, surface water, ground water under the direct influence of surface water (GWUDI), and brackish water.

\subsubsection{Groundwater}

Groundwater is water in all the voids within a geologic layer of fractured rock or soil. The sources of this groundwater are confined aquifers, unconfined aquifers including perched water tables, and leaky, or semiconfined aquifers. A confined aquifer is where impermeable strata covers groundwater so it is under more than atmospheric pressure as demonstrated by Figure 7. An unconfined aquifer (Figure 8) is where the water table fluctuates depending on recharge, human use, and permeability. A perched water table is an unconfined aquifer where water has been trapped by impermeable strata due to the rise and fall of the water table as seen in Figure 8. Figure 9 is a sketch of a leaky aquifer, or semiconfined aquifer. This is the most common type and is where a semiconfining, or semipervious layer, has a permeable strata on top or underneath it. 


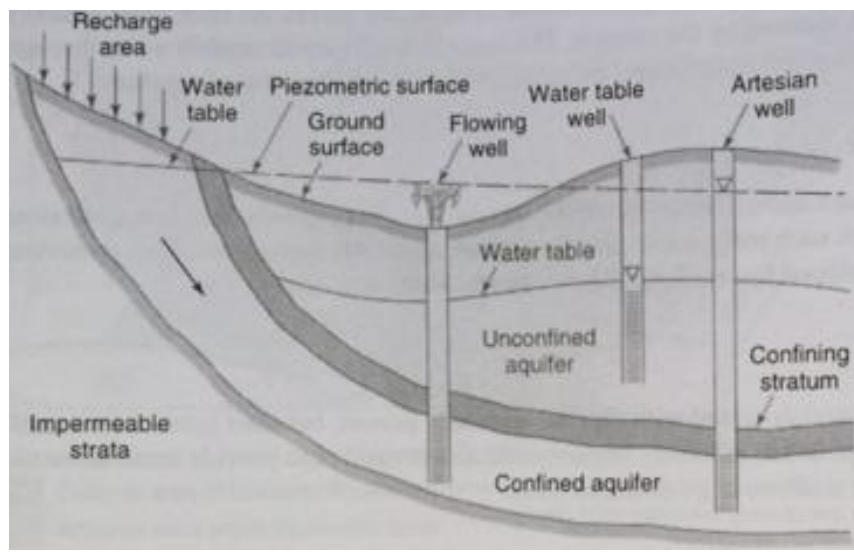

Figure 7: Sketch of Confined and Unconfined Aquifers (Todd et al., 2005)

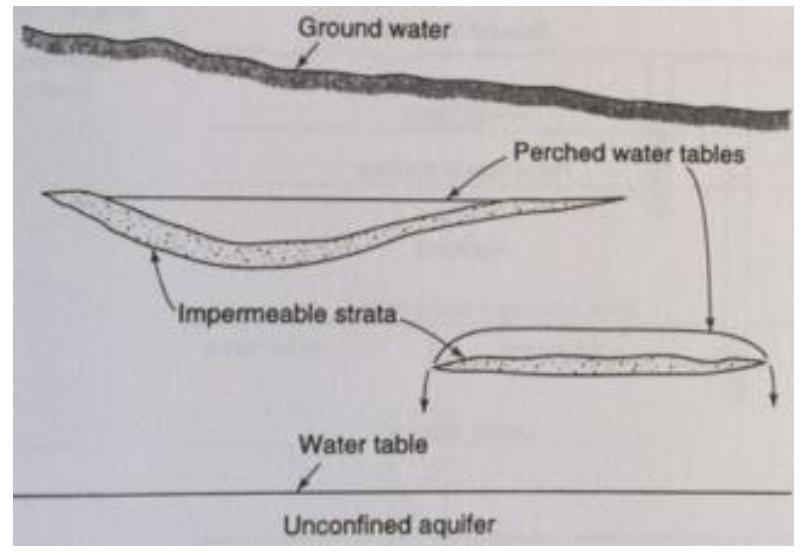

Figure 8: Sketch of Unconfined Aquifer with Perched Water Tables (Todd et al., 2005)

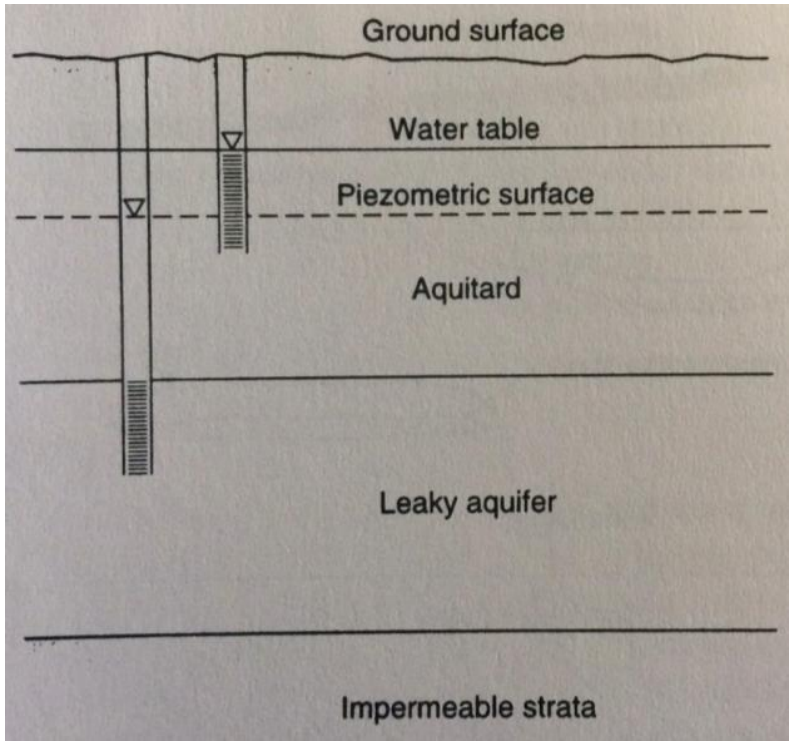

Figure 9: Sketch of Semiconfined, or Leaky Aquifer (Groundwater Hydrology, Todd et al., 2005) 
In the unconfined aquifer, natural recharge is the primary means for groundwater to be replenished because rain can percolate through the soil strata. Natural recharge can occur from precipitation, lakes, rivers, snow, and reservoirs. However, in confined aquifers, natural recharge is limited because of a confining stratum so many times artificial recharge is used by pumping water back into the confining aquifer.

The primary uses of groundwater are irrigation, industries, municipalities, and rural homes. This water is desirable because of availability, good water quality, and the low cost of extraction. The water quality is the primary reason groundwater is preferred to surface water. Infiltration and percolation through the soil strata filter the water and remove some contaminants so less, if any, filtration is required. However, groundwater can be contaminated if nearby sites spill waste or improperly dispose of chemicals. Tests are initially performed at sites to ensure good water quality and monitoring protects from future contamination.

\subsubsection{Surface Water}

Surface water consists of streams, rivers, lakes, wetlands, and the ocean which rain water tends to collect in. The water quality of this water is typically poor especially in urban environments because the runoff collects chemicals that cars or garbage leave behind. The water that is collected must be handled according to the Surface Water Treatment Rule discussed in Section VI, Water Rules and Regulations, in this chapter. This includes removing harmful contaminants through disinfection and filtration while monitoring to ensure water quality standards are met. 


\subsubsection{Groundwater Under the Direct Influence of Surface Water (GWUDI)}

GWUDI is a groundwater source that receives direct surface water recharge. Examples include some springs, shallow wells near surface water, and basins that allow water to percolate through the soil into groundwater sources. This category was created because the water is potentially contaminated with pathogens from the surface water which are not typically in true groundwater. This water must be treated according to the surface water treatment rules presented in Section VI, Water Rules and Regulations.

\subsubsection{Brackish Water}

Brackish water contains more salt than fresh water but less than sea water. Examples are estuaries, mangroves, deltas, brackish seas (i.e. Baltic Sea), and brackish lakes. This water must be desalinized before it can be used by humans which makes it a less common source of water and a significantly more expensive option. Saltwater intrusion can create brackish water in coastal communities if too much water is pumped from the aquifer. This can compromise a community's water supply so monitoring should be performed regularly to protect residents near the coast. If brackish water is detected, various treatment options or preventative measures will have to be considered to limit the saltwater intrusion.

\subsubsection{Treatment Plants}

Water and wastewater treatment plants ensure that water is treated and cleaned for use, such as drinking, recreational, and industrial needs. Water treatment plants treat source water and groundwater to ensure the safety of public drinking water and wastewater treatment plants ensure only treated water is pumped back into the 
environment. There is a wide variety of treatment options depending on the quality of water and thorough sampling is required to determine which method is most viable. Treatment options include chlorine disinfection, ozone disinfection, ultraviolet (UV) disinfection, advanced oxidation process (AOP), and many more.

\subsubsection{Distribution Network}

A water distribution network is composed of many parts that are interconnected in order to ensure the delivery of clean drinking water. Typically a water treatment plant receives water from a source such as a lake, river, reservoir, or groundwater. The water is treated and pumped through main transmission lines to large scale industrial users, storage reservoirs, or other water users. Water is conveyed from the storage reservoirs to the public through distribution mains and domestic lines. The network uses a looped system to distribute the water to ensure a certain level of redundancy in case of an event that disrupts part of the water distribution network.

\subsection{Redundancy}

Water distribution systems are built with a certain level of redundancy in order to operate normally during times of interruption. Such interruptions include maintenance, power outages, pump failures, intentional attacks, pipe failures, etc. The redundancy can be observed in a WDS with backup power generators, additional pumps, looped networks, etc.

Redundancy can be achieved through the basic design of the distribution network, branched vs looped networks. Branched networks (Figure 10) are less expensive but do not provide service to customers if a pipe failure were to occur. Looped networks (Figure 
11) are preferred because even if a pipe failure were to occur, the water can be redirected to continually provide services. Figure 10 shows a scenario where a pipe failure has occurred in a branched network and three customers are without service. In contrast, Figure 11 shows a similar looped network with a pipe failure but no customers are affected. The benefits of a looped network and the idea of redundancy are easily seen by the continued service to all customers in Figure 11. The redundancy of the WDS is very important as it ensures consumer service even if a failure were to occur somewhere in the system.

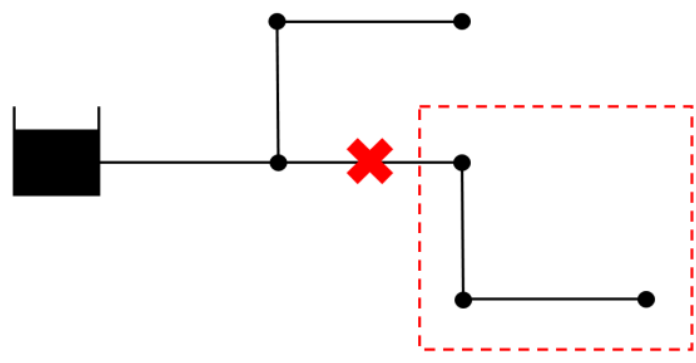

Figure 10: Schematic of Branched Network

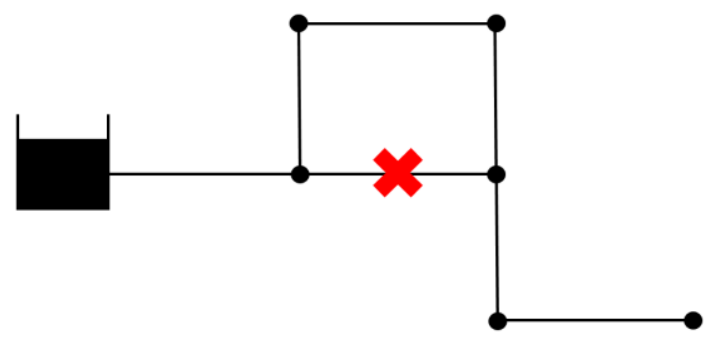

Figure 11: Schematic of Looped Network

\subsection{System Residual}

With the implementation of the Surface Water Treatment Rule of 1989, a disinfectant residual must be maintained throughout the water distribution system after primary disinfection. This residual is typically referred to as secondary disinfection. The reasons for this residual are to inactive microorganisms, indicate imbalances in the system, and control biofilm build up. Two problems with residuals are certain microbial pathogens are resilient, Cryptosporidium, and residuals can react with naturally occurring materials to form byproducts, trihalomethanes and haloacetic acids. The main secondary disinfectants are free chlorine, chloramines, and chlorine dioxide. Other secondary 
disinfectants that are being investigated include copper combined with hydrogen peroxide, silver combined with hydrogen peroxide, anodic oxidation, and potassium permanganate and ozone combined with hydrogen peroxide. Regulations regarding secondary disinfectants are presented in Table 1.

Free chlorine is the most common secondary disinfectant in the U.S. due to its effectiveness and long lasting residual. Free chlorine is used less with systems whose source waters have high concentrations of total organic carbons and bromide. Also, due to the potential for DBP formation, the distribution system residual may not exceed 4 $\mathrm{mg} / \mathrm{L}$ of $\mathrm{Cl}_{2}$ due to the disinfection byproducts (DBPs) rule. Chloramines are less common and control taste and odor. The main attractions of chloramines are that they produce lower concentrations of DBPs and they are more stable than free chlorines. The distribution system residual may also not exceed $4 \mathrm{mg} / \mathrm{L}$ of $\mathrm{Cl}_{2}$. Chlorine dioxide is even less common and used mainly in small systems. This is due to the residual not lasting as long in the system which makes their use in large systems unrealistic. A problem with chlorine dioxide is that it breaks down into chlorite which is a DBP with a maximum contaminant level (MCL) of $1 \mathrm{mg} / \mathrm{L}$. The distribution system residual may not exceed 0.8 $\mathrm{mg} / \mathrm{L}$ due to the DBPs rule. Cryptosporidium and some other viruses are resistant to these residuals so other methods of treatment are necessary especially if the source water has a high concentration. 
Table 1: Regulations for Secondary Disinfectant Residual (HDR)

\begin{tabular}{|c|c|c|}
\hline Regulation & Effective & Secondary Disinfection Elements \\
\hline $\begin{array}{l}\text { Surface Water Treatment } \\
\text { Rule (SWTR) }\end{array}$ & 1990 & $\begin{array}{l}\text { For all systems using surface water or groundwater under } \\
\text { the influence of surface water for supply, a detectable } \\
\text { disinfectant residual must be maintained within the } \\
\text { distribution system in at least } 95 \% \text { of the samples } \\
\text { collected (or heterotrophic bacteria counts must be less } \\
\text { than or equal to } 500 \mathrm{cfu} / \mathrm{ml} \text { as an equivalent) and at least } \\
0.2 \mathrm{mg} / \mathrm{L} \text { concentration of residual disinfectant (free or } \\
\text { combined) entering the distribution system must be } \\
\text { maintained. } \\
\text { Monitoring must be conducted throughout the distribution } \\
\text { system at same time and locations as those used for total } \\
\text { coliform monitoring and continuously at entry point. }\end{array}$ \\
\hline Total Coliform Rule (TCR) & 1990 & $\begin{array}{l}\text { - TCR does not require disinfectant residuals or monitoring } \\
\text { for disinfectant residuals. } \\
\text { TCR lists disinfectant residual as a Best Available } \\
\text { Technology for compliance with total coliform Maximum } \\
\text { Contaminant Level (MCL). }\end{array}$ \\
\hline $\begin{array}{l}\text { Stage 1 } \\
\text { Disinfectant/Disinfection } \\
\text { By-Products Rule (Stage 1 } \\
\text { DBPR) }\end{array}$ & 2002 & $\begin{array}{l}\text { - Establishes Maximum Disinfectant Residual Levels } \\
\text { (MRDLs) of } 4.0 \mathrm{mg} / \mathrm{L} \text { as } \mathrm{Cl}_{2} \text { for chlorine, } 4.0 \mathrm{mg} / \mathrm{L} \text { as } \mathrm{Cl}_{2} \\
\text { for chloramine, and } 0.8 \mathrm{mg} / \mathrm{L} \text { for chlorine dioxide. The } \\
\text { DBPR also lowers the MCL for total trihalomethanes } \\
\text { (TTHMS) from } 0.10 \mathrm{mg} / \mathrm{L} \text { (established in THM Rule) to } \\
0.080 \mathrm{mg} / \mathrm{L} \text {, and sets new MCLs for haloacetic acids } \\
\left(\mathrm{HAA}_{5}\right)(0.060 \mathrm{mg} / \mathrm{L} \text { ), chlorite }(1.0 \mathrm{mg} / \mathrm{L} \text { ), and bromate } \\
(0.010 \mathrm{mg} / \mathrm{L}) \text {. System may use SWTR disinfectant } \\
\text { residual monitoring results to determine MRDL } \\
\text { compliance. } \\
\text { Monitoring must be conducted throughout the distribution } \\
\text { system at same time and locations as those used for total } \\
\text { coliform monitoring and continuously at entry point }\end{array}$ \\
\hline
\end{tabular}




\subsection{Water Rules and Regulations}

This section presents rules and regulations that increase the safety of the public drinking water systems throughout the US. These rules are created and implemented by the EPA in order to provide cleaner drinking water by reducing the risk of microbial contaminants in the WDS.

\subsubsection{Clean Water Act}

The Clean Water Act (CWA) was passed through Congress in 1972. This act is a significant change of the Federal Water Pollution Control Act of 1948. The purpose was to provide a regulating structure for discharge of pollutants and for quality standards of waters in the United States. The act forbade the discharge pollutants from a point source, such as a pipe or ditch, into navigable waters without a National Pollutant Discharge Elimination System (NPDES) permit. In addition, the act helps to get funding the construction of sewage treatment plants due to new wastewater standards that the EPA implemented with the CWA.

\subsubsection{Safe Drinking Water Act}

The Safe Drinking Water Act (SDWA) of 1974 was created to protect drinking water and its sources as well as to regulate the nation's public drinking water supply. The SDWA is the main federal law that safeguards water quality. Threats to the system include animal and human waste, pesticides, improperly disposed of chemicals, and naturally occurring substances. The EPA set national health-based standards for drinking water quality that applies to all $160,000+$ public water systems in the US. These standards protect drinking water from contaminants and other threats. This does not apply to private wells that serve less than 25 people. An amendment in 1996 changed the focus 
of the SDWA from treatment of the water to increasing laws relating to funding for system improvements, source water protections, and public information. These components greatly increase the protection of drinking water by ensuring the quality from source to tap. Another important aspect of the SDWA is the underground injection control (UIC) program which regulates injection wells that put liquid into the ground for storage or disposal purposes.

\subsubsection{Surface Water Treatment Rules}

In order to further increase the safety of drinking water supplies, the EPA created the surface water treatment rules (SWTR) in conjunction with the disinfectants and disinfectants byproducts rules. All these rules were developed to decrease the presence of microbial contaminants in the water and reduce the risk posed by disinfectants and disinfectant byproducts (DBPs). Figure 11 shows the progression of rules relating to limiting DBPs. Presented below are the five SWTRs with a brief description of each.

a. Surface Water Treatment Rule of 1989

b. Interim Enhanced Surface Water Treatment Rule of 1998

c. Filter Backwash Recycling Rule of 2001

d. Long Term 1 Enhanced Surface Water Treatment Rule of 2002

e. Long Term 2 Enhanced Surface Water Treatment Rule of 2006

\subsubsection{Surface Water Treatment Rule of 1989}

The SWTR of 1989 requires microbial contaminants to be removed through filtration and disinfection in surface water and groundwater under the direct influence of surface water (GWUDI). The rule is intended to decrease public health risk to contaminants such as viruses, Giardia lamblia, and Legionella by setting maximum contaminant level goals (MCLGs) at zero $\mathrm{mg} / \mathrm{L}$. The goals are set at zero because the 
presence of the contaminants at source waters and the health risks associated with exposure. The rule specifies that treatment should be adequate to reduce source water concentration of Giardia lamblia by $99.9 \%$ (3 log removal) and viruses by $99.99 \%$ (4 log removal). The SWTR determines filtration systems performance by measuring turbidity and requiring a disinfectant residual to be maintained throughout the water system at a detectable level. The most common residual disinfectant is chlorine but chlorine may interact with some naturally-occurring materials to create byproducts which could be a hazard to the health of users. Another important part of the SWTR is the absence of any control for Cryptosporidium, which has a high resilience to chorine disinfection.

\subsubsection{Interim Enhanced Surface Water Treatment Rule of 1998}

The Interim Enhanced Surface Water Treatment Rule (IESWTR) of 1998 improves public health protection by reducing the risk of microbial contaminants, in particular, Cryptosporidium and disinfection byproducts. Cryptosporidium is an important contaminant because of its resistance to chlorine disinfection combined with its adverse health effects. The IESWTR requires a lower turbidity standard which improves filtration performance. It also only applies to systems serving greater than 10,000 people with surface water sources or groundwater under the direct influence of surface water.

\subsubsection{Filter Backwash Recycling Rule of 2001}

The Filter Backwash Recycling Rule (FBRR) requires the filter backwash water from treatment plants to be recycled. This backwash must be filtered through all processes of filtration and monitoring data must be sent to the state. The FBRR is employed to reduce the presence of microbial contaminants in public drinking water systems. 


\subsubsection{Long Term 1 Enhanced Surface Water Treatment Rule of 2002}

Long Term 1 Enhanced Surface Water Treatment Rule (LT1) expands the IESWTR to water systems serving less than 10,000 people. It increases control of microbial pathogens, such as Cryptosporidium, and addresses additional concerns with disinfection byproducts. These controls include improving filtration requirements and requiring systems to determine microbial inactivation. The latter requirement is used for microbial protection of systems that make changes to avoid disinfection byproducts.

\subsubsection{Long Term 2 Enhanced Surface Water Treatment Rule of 2006}

Long Term 2 Enhanced Surface Water Treatment Rule (LT2) specifies additional treatment for Cryptosporidium and other microbial contaminants if significant levels are found at the source waters. This applies to surface water or GWUDI systems. In addition, the LT2SWTR reduces potential risk from disinfection byproducts by implementing rules that address the cost/benefit of certain pathogens and DBPs. 


\subsubsection{Drinking Water Strategy}

The Drinking Water Strategy (DWS) was developed in 2010 by the EPA to further increase protection of drinking water from contaminants as well as to promote speedy and cost-effective new technologies. The DWS has 4 goals as described below:

The first goal is to address contaminants in groups as opposed to individually. This promotes a cost and time effective means to protect water supplies. Grouping contaminants like this allows facilities to improve treatment methods more efficiently by protecting against a greater number of contaminants more easily.

The second goal is to promote new drinking water technologies that will protect against a wider variety of contaminants. The Water Technology Innovation Cluster was created to develop, test, and market these new technologies.

The third goal is to use laws to ensure our drinking water is protected. A list of over 130 chemicals was compiled due to their potential harmful effects to the endocrine system. This list allows for screening of these chemicals to determine their concentrations in water sources and determine if additional testing is necessary.

The last goal is to allow for shared access to public water systems monitoring data between the EPA and states. This will increase the use of advanced information technologies and will allow states, industry, and consumers to obtain information about drinking water quality and performance. The sharing of data will also enhance review of drinking water health issues without further information collecting problems. 


\subsection{Contaminants and Monitoring}

\subsubsection{Contaminants of Concern}

The National Public Drinking Water Regulations have standards for limiting contaminants in drinking water. Contaminants that may endanger public safety are being continuously updated to ensure the safety of drinking water systems. There are several types of contaminants that may put public health at risk and they include microorganisms, disinfection byproducts, disinfectants, inorganic chemicals, and organic chemicals. Table 2 provides an abbreviated list of the microorganisms that are monitored and their maximum contaminant level goals (MCLG). A complete list of the contaminants of concern is located in Appendix B.

Cryptosporidium is particularly important to examine because of its resistance to chlorine disinfection and history of outbreaks. The most notable outbreak was in Milwaukee, Wisconsin in 1993 where more than 400,000 people became ill due to the contaminated drinking water. This contaminated drinking water was linked back to the city water supply system. The outbreak along with the several other incidents involving Cryptosporidium around the world has prompted new regulations and monitoring standards. For more information on the regulations, view section VI of Chapter 2, Water Rules and Regulations. 
Table 2: Abbreviated Version of Microorganisms of Concern (Drinking Water)

\begin{tabular}{|c|c|c|c|c|}
\hline \multicolumn{5}{|l|}{ Microorganisms } \\
\hline Contaminant & $\begin{array}{l}\mathrm{MCLG}_{2}^{1} \\
(\mathrm{MG} / \mathrm{L})^{2}\end{array}$ & $\begin{array}{l}\text { MCL } 1 \\
\text { or } T^{1} \\
(\mathrm{MG} / \mathrm{L})^{2}\end{array}$ & $\begin{array}{l}\text { Potential Health Effects from Long-Term Exposure Above } \\
\text { the MCL (unless specified as short-term) }\end{array}$ & $\begin{array}{l}\text { Sources of } \\
\text { Contaminant in } \\
\text { Drinking Water }\end{array}$ \\
\hline Cryptosporidium & zero & $\mathrm{TT}^{3}$ & $\begin{array}{l}\text { Gastrointestinal illness (such as diarrhea, vomiting, and } \\
\text { cramps) }\end{array}$ & $\begin{array}{l}\text { Human and animal } \\
\text { fecal waste }\end{array}$ \\
\hline Giardia lamblia & zero & $\mathrm{TT}^{3}$ & $\begin{array}{l}\text { Gastrointestinal illness (such as diarrhea, vomiting, and } \\
\text { cramps) }\end{array}$ & $\begin{array}{l}\text { Human and animal } \\
\text { fecal waste }\end{array}$ \\
\hline Viruses (enteric) & zero & $\mathrm{TT}^{3}$ & $\begin{array}{l}\text { Gastrointestinal illness (such as diarrhea, vomiting, and } \\
\text { cramps) }\end{array}$ & $\begin{array}{l}\text { Human and animal } \\
\text { fecal waste }\end{array}$ \\
\hline Legionella & zero & $\mathrm{TT}^{3}$ & Legionnaire's Disease, a type of pneumonia & $\begin{array}{l}\text { Found naturally in } \\
\text { water; multiplies in } \\
\text { heating systems }\end{array}$ \\
\hline
\end{tabular}




\subsubsection{Monitoring}

The EPA must remain vigilant against all threats to water supplies and this is accomplished through monitoring water quality. Water quality monitoring includes sampling and analysis to determine water constituents and current conditions. These constituents include pollutants that are introduced by humans (oils, pesticides, metals, microorganisms, etc) and naturally occurring constituents (dissolved oxygen, bacteria, nutrients, etc). According to the EPA, there are 4 reasons to monitor water quality. 1. Determine if the water is meeting designated usage guidelines. These uses include fishing, swimming, and drinking. Pollutants must be monitored to ensure that they do not exceed certain thresholds.

2. Identify specific pollutants and their sources. This allows the EPA to determine responsible parties if pollutants are introduced into water sources.

3. Access trends in long term monitoring. This helps determine if water sources are changing due to human involvement and aid in rehabilitating contaminated sources to natural conditions.

4. Screen for impairment. Monitoring provides an early warning system to users of the water so pollutants can be contained to mitigate risk to human health.

Due to the wide variety of contaminants, monitoring is performed by using sensors and instruments that are able to detect changes in baseline water quality. Some of the factors that the sensors measure are $\mathrm{pH}$, total chlorine, total organic carbon (TOC), temperature, and turbidity. An important contribution to water quality monitoring is the development of network based detection systems in order to create a clearer overall picture of the WDS. In addition to this system, continuous sampling is being 
implemented to replace sampling every day or every month. The cheap, commercially available sensors are typically between $\$ 5,000$ to $\$ 10,000$ (Hall, 2009), therefore it is reasonable to assume sensors that continuously monitor water quality and are networked together may be quite expensive. With new developments in technology and software, monitoring will become easier to implement and will continue to protect water supplies from a broad array of contaminants, both naturally occurring and man-made.

When designing a water quality monitoring program, an engineer must use the monitoring location to determine what pollutants will most likely be associated with that location. Table 4 shows several examples of sources along with associated pollutants. Also, volunteer water quality monitoring programs should be involved to ensure continuously uncontaminated water.

Table 3: Pollutants Associated with Certain Sources (Chapter 5)

\begin{tabular}{|c|c|}
\hline Source & Common Associated Chemical Pollutants \\
\hline Cropland & Turbidity, phosphorus, nitrates, temparature, total solids \\
\hline $\begin{array}{l}\text { Forestry } \\
\text { harvest }\end{array}$ & Turbidity, temperature, total solids \\
\hline Grazing land & Fecal bacteria, turbidity, phosphorus, nitrates, temperature \\
\hline $\begin{array}{l}\text { Industrial } \\
\text { discharge }\end{array}$ & Temperature, conductivity, total solids, toxics, $\mathrm{pH}$ \\
\hline Mining & $\mathrm{pH}$, alkalinity, total dissolved solids \\
\hline Septic systems & $\begin{array}{l}\text { Fecal bacteria (i.e., Escherichia coli, enterococcis), nitrates, phosphorus, dissolved } \\
\text { oxygen/biochemical oxygen demand, conductivity, temperature }\end{array}$ \\
\hline $\begin{array}{l}\text { Sewage } \\
\text { treatment } \\
\text { plants }\end{array}$ & $\begin{array}{l}\text { Dissolved oxygen and biochemical oxygen demand, turbidity, conductivity, phosphorus, } \\
\text { nitrates, fecal bacteria, temperature, total solids, } \mathrm{pH}\end{array}$ \\
\hline Construction & $\begin{array}{l}\text { Turbidity, temperature, dissolved oxygen and biochemical oxygen demand, total solids, } \\
\text { and toxics }\end{array}$ \\
\hline Urban runoff & $\begin{array}{l}\text { Turbidity, phosphorus, nitrates, temperature, conductivity, dissolved oxygen and } \\
\text { biochemical oxygen demand }\end{array}$ \\
\hline
\end{tabular}




\section{VULNERABILITY ANALYSIS}

\subsection{Vulnerability Categories}

Analyzing various vulnerability categories is an important aspect of determining possible weaknesses and threats associated with the WDS. According to Haimes and colleagues (Haimes et al., 1998), the vulnerability categories are as follows.

\subsubsection{Physical Threats}

Physical threats to water facilities are physical damage to the water system. Facilities that are at risk include dams, levees, water and wastewater facilities, storage tanks, pipes, etc. These types of threats can be acts of terrorism or natural disasters.

Possible solutions to these physical threats are designing for natural disasters, fencing in vital areas, locking doors and gates, installing cameras, maintaining well lit areas, employee patrols, and using alarm systems. Other procedural controls can be implemented to deter threats such as changing access codes regularly, requiring identification cards, inventorying keys, and monitoring contractors and other temporary workers in the area. These are only a few of the solutions that could help to mitigate physical threats to critical water infrastructure.

\subsubsection{Chemical and Biological Threats}

Chemical and biological threats include both intentional and accidental contamination events that affect the water distribution system. These threats can be the most dangerous because if the contamination is not detected, thousands of people can be exposed to the harmful contaminants. Contamination events can include reservoir contamination, terrorists introducing harmful microorganisms, accidental over- or under- 
dosing chemicals in the treatment process, and groundwater or surface water contamination.

\subsubsection{Cyber Threats}

Water facilities are at risk for cyber intrusion because of their use of industrial control systems and electronic networks. These systems monitor and control intakes, sewage collection, water and sewage treatment, effluent discharge, and other processes. In the event of a cyber-attack, a hacker may use chemicals to overdose or under dose, discharge untreated sewage, disrupt water distribution, or send tampered or false data to the operators. This can have serious consequences on users who may receive contaminated drinking water or swim in waters that have untreated sewage flowing in them.

Due to several recent cyber intrusions, a more detailed description of cyber security will be provided. These intrusions include threats that ended in physical damage, the centrifuges in Iran (Sanger, 2012) where hackers were able to send false data to the centrifuges in order to make them run faster and ultimately break. Another type of cyber intrusion is information theft such as the hack on Sony (Pepitone, 2015) where hackers were able to obtain extensive personal information about individuals in the company. In recent years, there have been several important measures to reduce cybersecurity risks. In 2008, the "Roadmap to Secure Control Systems in the Water Section" was developed to provide a 10-yr vision for water facility control systems to remain functional in the event of a cyber-attack. The document expresses the need for finding ways to detect, respond to, and mitigate consequences of attacks on the control systems. In response to this, the American Water Works Association (AWWA) developed guidelines that reduce the risk 
of cyber-attack by identifying prioritized actions for water and wastewater facilities. Another measure is to promote information sharing through analysis centers, host monthly cyber threat briefings to always be informed on evolving threats, and have a Water Information Sharing and Analysis Center (ISAC) that receives reports on cyber incidents in order to relay the possible threats to facility operators.

Many techniques have been developed in recent years to ensure minimal consequences if a cyber-attack occur. The first is to employ manual overrides should critical systems be compromised. Also, storing water in the distribution system and having the capability to isolate certain systems from the Internet are important options that ensure facilities can stay operational during an attack. Another technique is for facilities to be custom designed which ensures that there are very few common processes or systems that hackers could use to spread out to multiple facilities and disrupt large water systems. Finally, chemicals cannot be remotely released and control systems do not allow operators to perform actions that may endanger containment.

Cybersecurity will always be an important topic but due to recent developments and safety procedures, it is unlikely that a cyber-attack will cause widespread contamination with adverse effects on public health or safety. However, an attack may cause a temporary disruption of normal operations in water and wastewater facilities.

For the research presented in this study, we examine the threat of intentional chemical or biological contamination in the distribution system because it is the most likely method that would be employed. This is due to the higher level of cyber security and the inherent difficulty in physically harming the water infrastructure to a level that would be significant and far reaching. 


\subsection{Points of Contamination}

Water distribution systems are large systems covering many square miles so intentional and accidental contaminations are inherent. There are numerous points where contamination is likely and some of these are more susceptible than others. Chemical or biological contamination is the most serious because of the likeliness of intentional contamination and widespread distribution. The entry points of possible contamination are highlighted and briefly discussed below.

\subsubsection{Water Treatment Plant}

Treatment plants rely on surface water for large scale water systems and groundwater for smaller, community water systems. According to the EPA, about $68 \%$ of the population is served with water from surface water sources while about $32 \%$ of the population gets their water from groundwater sources. As discussed earlier, surface water is more easily contaminated than groundwater due to its ease of access. Contaminated surface or groundwater does not mean the population is at risk due to the strict treatment and monitoring guidelines set up by the EPA. The regulations ensure that source water will be properly treated and monitored in order to ensure the safety of the public. Even if no treatment is available for a specific contaminant, a treatment plant may shutdown to stop the spread of the contaminant.

\subsubsection{Tanks and Reservoirs}

For this research, tanks and reservoirs will be a primary target for an intentional contamination event because these are the easiest to access. This ease of access is due to their remote locations and limited security. Fencing may be the only line of defense for the tanks and there is an extensive challenge in constantly surveying the entire reservoir. 
These systems are desirable as contamination sources because they could quickly affect a large population. Tanks receive water during low demand periods while delivering water during high periods which make high demand periods enticing times to contaminate.

\subsubsection{Pump Stations}

Pump stations are usually protected from tampering or sabotage by reinforced concrete, steel, and masonry wall construction with no standard windows. Occasionally some pumping equipment may be located in outside enclosures which increases the chances of tampering. However, these locations are not constantly monitored so outside access is still possible. If accessed, the shutdown or tampering of valves may cause significant problems throughout the system especially if contaminants are allowed to enter the system at these key locations.

\subsubsection{Hydrants}

Hydrants are easily accessible to people and the only current means of protection is hydrant locks which are aftermarket ad-ons. These locks are often only used in places that have experienced vandalism and are not used "preemptively over broader areas of the distributions system (Hydrant, 2011)." A possible solution is a check valve which blocks the backflow so contaminants cannot enter the system while allowing emergency services access to the hydrants for firefighting capabilities. Another difficult part of contaminating hydrants is having the proper equipment (portable tank, pump, and motor assembly) and not attracting unwanted attention which is difficult because the pumping would be loud and obvious to nearby people. The proximity of hydrants to largely populated areas is the main reason that this contamination issue is unlikely and will not be examined in this research. 


\section{METHODOLOGY}

\subsection{Terminology}

\subsubsection{Water Fraction}

$\mathrm{W}(\mathrm{i}, \mathrm{j})$ is the fraction of water that contributes to monitoring station $\mathrm{i}$ from node $\mathrm{j}$.

An example water distribution network is shown in Figure 12. It shows node J3000 contributes $85 \%$ of its water to monitoring station J4000, therefore, $\mathrm{W}(\mathrm{J} 4000, \mathrm{~J} 3000)=0.85$. It can be assumed that the water quality at $\mathrm{J} 4000$ is representative of the water quality at $\mathrm{J} 3000$ if $\mathrm{W}(\mathrm{i}, \mathrm{j})$ is greater than the coverage criterion.

\subsubsection{Coverage}

Refers to whether the water quality at a particular node is representative of the source node. If the water fraction is greater than the coverage criterion then it is covered.

In Figure 12, node $\mathrm{J} 4000$ is a coverage of $\mathrm{J} 3000$ or node $\mathrm{J} 4000$ is covered by J3000

\subsubsection{Coverage Criterion}

A pre-defined criterion to determine if the water quality at one node can represent the water quality at another.

In this study a coverage criterion of 0.50 is used. The $\mathrm{W}(\mathrm{J} 4000, \mathrm{~J} 3000)$ is 0.85 , meaning that node $\mathrm{J} 4000$ is representative of node $\mathrm{J} 3000$, or covered by $\mathrm{J} 3000$. If the water fraction were to be less than 0.50 than node $\mathrm{J} 4000$ is not representative of $\mathrm{J} 3000$. Since $\mathrm{W}(\mathrm{J} 5000, \mathrm{~J} 3000)=0.15$, the water quality at $\mathrm{J} 5000$ cannot be representative of the water quality at $\mathrm{J} 3000$ because it is less than the coverage criterion. 


\subsubsection{Coverage Ratio}

The ratio of demand covered by the selected monitoring stations to the total demand.

For example, say the set of monitoring stations covers a demand of 905 out of a total demand of 1000 . The coverage ratio of the WDS is calculated to be 0.905 which means that $90.5 \%$ of the total demand is covered by the selected monitoring stations.

\subsubsection{Demand Pattern}

The usage demands at a single node combined with a demand multiplier that changes throughout a 24 hour cycle.

Figure 13-16 show the demand patterns used in this study. Demand pattern 2.0 will raise a nodes demand in the morning and at night to simulate peak hours of water use. While demand pattern 3.0 will raise the demand during the middle of the day (Figure 14).

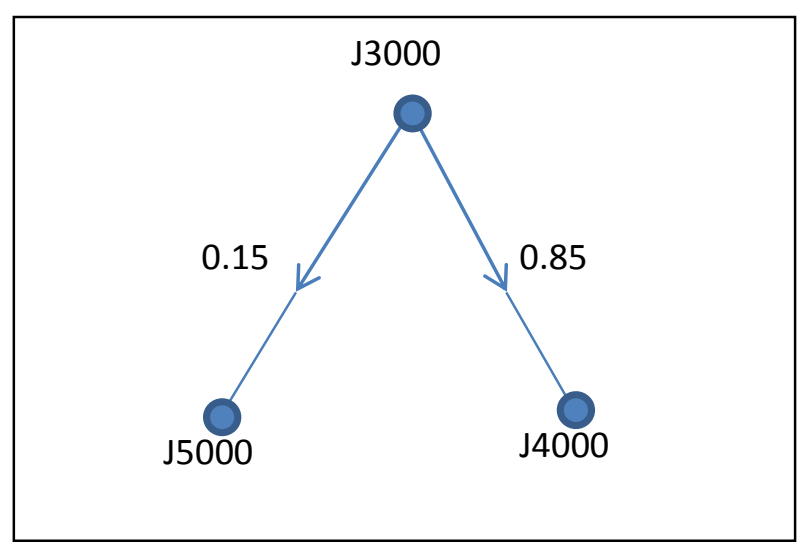

Figure 12: Example WDS 


\subsection{EPANET Theories}

EPANET is the software utilized by WaterCAD for the analysis of the system response to various demands.

\subsubsection{Advection Transport Theory}

The principal transport mechanism throughout the system is advection while longitudinal dispersion is negligible under normal operating conditions. This means that a dissolved substance will travel at the same average velocity in the pipe as the surrounding fluid while reacting (growing or decaying) at a given rate. No mixing occurs between adjacent segments of water. This transport mechanism is expressed in the following equation:

$$
\frac{\partial C_{i}}{\partial t}=-u_{i} \frac{\partial C_{i}}{\partial x}+r\left(C_{i}\right)
$$

$$
\begin{aligned}
& \text { Where: } \quad \mathrm{C}_{\mathrm{i}} \quad=\text { Concentration (mass/volume) in pipe } \mathrm{i} \\
& \mathrm{u}_{\mathrm{i}} \quad=\text { Flow velocity (length/time) in pipe } \mathrm{i} \\
& \mathrm{r}=\text { Rate of reaction (mass/volume/time) } \\
& \mathrm{t} \quad=\text { Time } \\
& \mathrm{x}=\text { Longitudinal distance in pipe } \mathrm{i}
\end{aligned}
$$




\subsubsection{Junction Mixing Theory}

The mixing of fluids at junctions that receive inflow from two or more pipes is assumed to be complete and instantaneous. Therefore, the concentration of a substance at the junction outflow is the flow-weighted sum of inflow concentrations. For a particular node $\mathrm{k}$, the equation is:

$$
C_{i \mid x=0}=\frac{\sum_{j \varepsilon I_{k}} Q_{j} C_{j \mid x=L_{j}}+Q_{k, \text { ext }} C_{k, \text { ext }}}{\sum_{j \varepsilon I_{k}} Q_{j}+Q_{k, \text { ext }}}
$$

Where: $\quad \begin{array}{ll}\mathrm{i} & =\text { Link with flow leaving node } \mathrm{k} \\ \mathrm{I}_{\mathrm{k}} \quad & \text { Set of links with flow into } \mathrm{k} \\ \mathrm{L}_{\mathrm{j}} & =\text { Length of link } \mathrm{j} \\ \mathrm{Q}_{\mathrm{j}} \quad & =\text { Flow (volume/time) in link } \mathrm{j} \\ \mathrm{Q}_{\mathrm{k}, \mathrm{ext}} \quad=\text { External source flow entering at node } \mathrm{k} \\ \mathrm{C}_{\mathrm{k}, \mathrm{ext}} \quad=\text { Concentration of external flow entering at node } \mathrm{k} \\ \mathrm{C}_{\mathrm{i} \mid \mathrm{x}=0} \quad=\text { Concentration at start of link } \mathrm{i} \\ \mathrm{C}_{\mathrm{i} \mid \mathrm{x}=\mathrm{L}} \quad=\text { Concentration at end of link } \mathrm{i}\end{array}$




\subsubsection{Storage Mixing Theory}

The contents of tanks, reservoirs, and other storage facilities are assumed to be completely mixed. This is a valid assumption because the tanks operate under fill-anddraw conditions with minimum momentum flux being conveyed to the inflow (Rossmand and Grayman, 1999). With this assumption, the contents of the tanks are a mixture of current contents and inflow water. Due to various reactions, however, the internal concentration may be changing. The equation that represents the mixing is:

$$
\frac{\partial\left(V_{s} C_{S}\right)}{\partial t}=\sum_{I \varepsilon I_{S}} Q_{i} C_{i \mid x=L_{i}}-\sum_{j \varepsilon O_{S}} Q_{j} C_{s}+r\left(C_{s}\right)
$$

Where: $\quad \begin{array}{cl}\mathrm{V}_{\mathrm{s}} & =\text { volume in storage at time } \mathrm{t} \\ \mathrm{C}_{\mathrm{s}} & =\text { concentration within the storage facility } \\ \mathrm{I}_{\mathrm{s}} & =\text { set of links providing flow into facility } \\ \mathrm{O}_{\mathrm{s}} & =\text { set of links withdrawing flow from facility }\end{array}$




\subsubsection{System of Equations}

The following conditions are applied to equation 1-3 in order to solve for the concentration in each pipe as well as the concentration in each storage facility (tank or reservoir):

- initial conditions specifying $C_{i}$ for all $x$ in each pipe $i$ and $C_{s}$ in each storage facility s at $\mathrm{t}=0$

- boundary conditions specifying values for $C_{k, e x t}$ and $Q_{k, \text { ext }}$ for all time $t$ at each node $\mathrm{k}$ which has external mass inputs

- hydraulic conditions specifying the volume $\mathrm{V}_{\mathrm{s}}$ in each storage facility s and the flow $\mathrm{Q}_{\mathrm{i}}$ in each link $\mathrm{i}$ at all times $\mathrm{t}$

\subsubsection{Bulk Flow Reactions}

These reactions occur between substances in the pipe or storage facility and the constituents in the water. For this study the bulk flow is assumed to be zero. This is a conservative approach because the study is assuming the contaminant does not degrade throughout the system but rather is primarily traveling by advection. Without degradation, the contaminant would have a higher concentration when humans consumed it so the analysis is for a worst case scenario.

\subsubsection{Lagrangian Transport Algorithm}

A Lagrangian time-based approach is used by EPANET to track discrete water parcels as they travel and mix together throughout the system. Due to the quick travel times within pipes, short water quality time steps (minutes) are used instead of the longer hydraulic time steps (hours). 


\subsection{Number of Optimal Monitoring Stations}

The optimal number of monitoring stations is difficult to determine due to limits in funding and evolving threats to the WDS. The number of monitoring stations should be at least the same as the number of tanks, if economically feasible, but more would be recommended for complete coverage. The closest nodes to the tanks will detect contamination immediately before it spreads throughout the system so these would be the bare minimum of the monitoring locations. This results in at least seven monitoring stations for the CITY in this study.

However, if contamination occurred in another point of the distribution system or along the main transmission line then the optimal locations for monitoring stations would be different and there should be an increase in the number of nodes being monitored. This makes it difficult to determine the most vulnerable aspect of the system because it is an ever-evolving threat. The ultimate number of nodes should be dependent on economic feasibility as well as inherent risk to the distribution system. In this study, the best 15 monitoring locations in the WDS are determined because these will provide significant protection at a reasonable cost for a WDS serving 30,000 to 40,000 residents. The monitoring stations are listed in order of importance in case the CITY cannot afford all 15 but must purchase fewer due to insufficient funding. 


\subsection{Chosen Model Type}

The WDS came with a wide variety of demand patterns. These help to determine if the temporal distribution affects the location of the optimal monitoring stations. Two types of demand patterns will be examined: steady state and unsteady state. The steady state analysis represents a baseline to determine if the changing temporal distribution affects the location of the best monitoring stations while unsteady state represents a more realistic examination of the WDS.

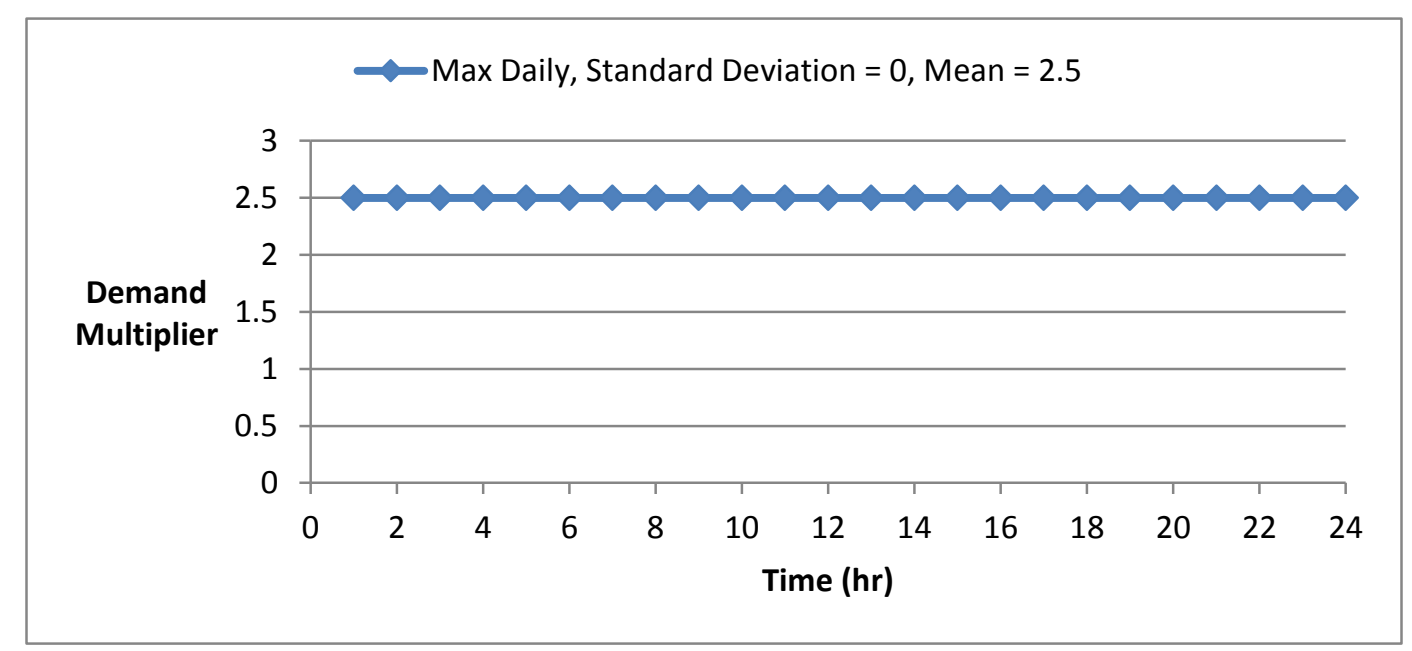

Figure 13: Max Daily Demand Pattern

Several models were developed for the CITY. Steady state and unsteady state hydraulics are used. For steady state, an average daily demand and max daily demand were available but only max daily demand will be used. Max daily demand is used in order to be conservative and assume the worst case scenario such as peak water use during a hot summer day (Figure 13). For unsteady state, patterns 2.0, 3.0, 4.0, 5.0, 6.0, \& 7.0 will be used. These patterns have varying temporal distributions to simulate different 
ways the water may be used in a given day. A more detailed description of the patterns can be seen in Figure 14-16.

The analysis disregards the nodes along the main transmission line because these are harder to contaminate and stations located throughout the distribution system would be more site specific.

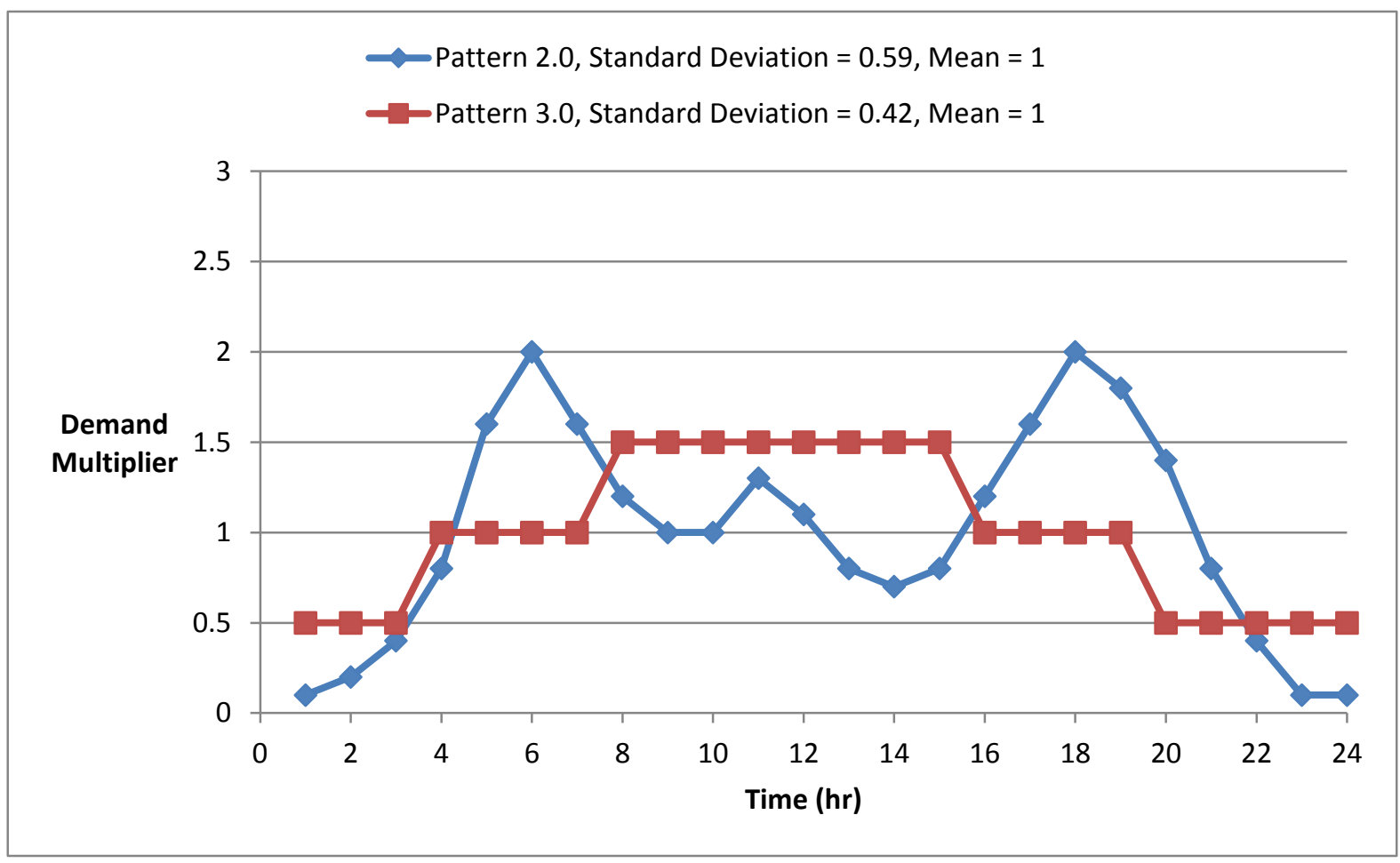

Figure 14: Demand Pattern 2.0 and 3.0 


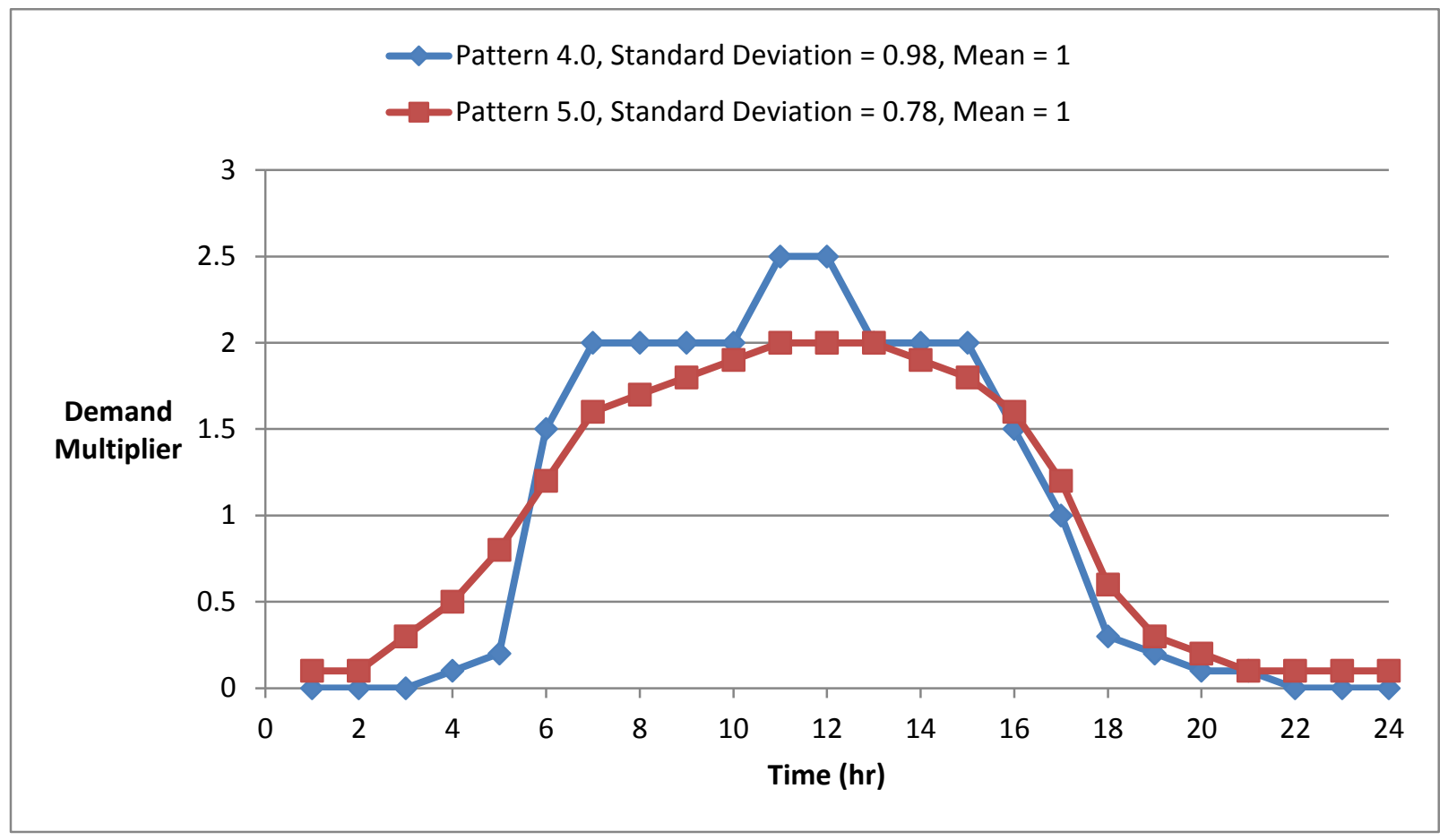

Figure 15: Demand Pattern 4.0 and 5.0

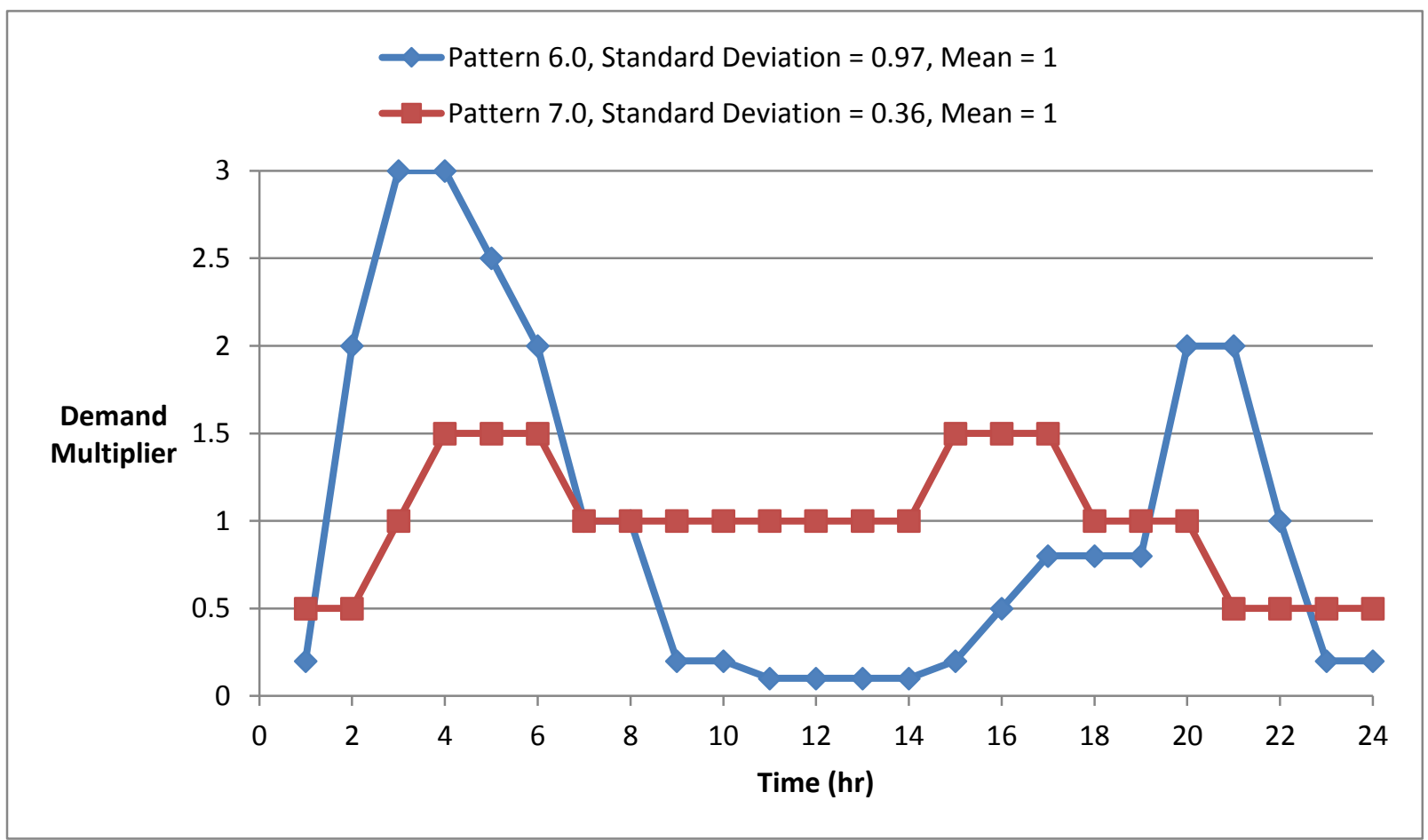

Figure 16: Demand Pattern 6.0 and 7.0 


\subsection{The "CITY" Examined}

Description: The city serves 30,000 to 40,000 residents and will remain anonymous throughout the paper to protect the WDS, as well as the users and operators of the system. It contains 654 nodes, 619 in water distribution system and 35 in the main transmission line. There are 13 pressure reducing valves located throughout the main transmission line, as well as 10 tanks and 5 wells. Figure 17 shows all the various components of the WDS. How it Works: The system starts at T-92, which we can assume is a water treatment plant or large reservoir, where the water begins flowing through the main transmission lines. This water enters the water distribution system through 13 pressure reducing valves (PRVs) and propagates throughout the network. Pressure reducing valves reduce a high pressure at the inlet to a lower, steadier pressure at the outlet. The PRV works automatically as the flow rate changes and inlet pressure varies. Water is stored in tanks and wells. The booster schedule in Table 4 shows when the tanks open their isolation valves to provide the system with water. A pump is used to pressurize the water to the current operating pressure. When the tank is closed off from the system, it does not contribute to the hydraulics. This water serves the community according to the booster schedule of the tanks. The remaining water in the main transmission lines exit the system through T-91 and T-93.

Table 4: Booster Schedule for Tanks

\begin{tabular}{|c|c|c|}
\hline Tank \# & Boost Days & Boost Times \\
\hline 1 & Thursday, Sunday & $5 \mathrm{am}-8 \mathrm{am}$ \\
\hline 2 & Tuesday, Saturday & $5 \mathrm{am}-9 \mathrm{am}$ \\
\hline 3 & Thursday, Sunday & $5 \mathrm{am}-9 \mathrm{am}$ \\
\hline 4 & Tuesday, Saturday & $5 \mathrm{am}-9 \mathrm{am}$ \\
\hline 5 & Monday, Wednesday, Friday & $4 \mathrm{am}-9 \mathrm{am}$ \\
\hline 6 & Monday, Wednesday, Friday & $5 \mathrm{am}-4 \mathrm{pm}$ \\
\hline 7 & Monday, Wednesday, Friday & $4 \mathrm{pm}-10 \mathrm{pm}$ \\
\hline
\end{tabular}




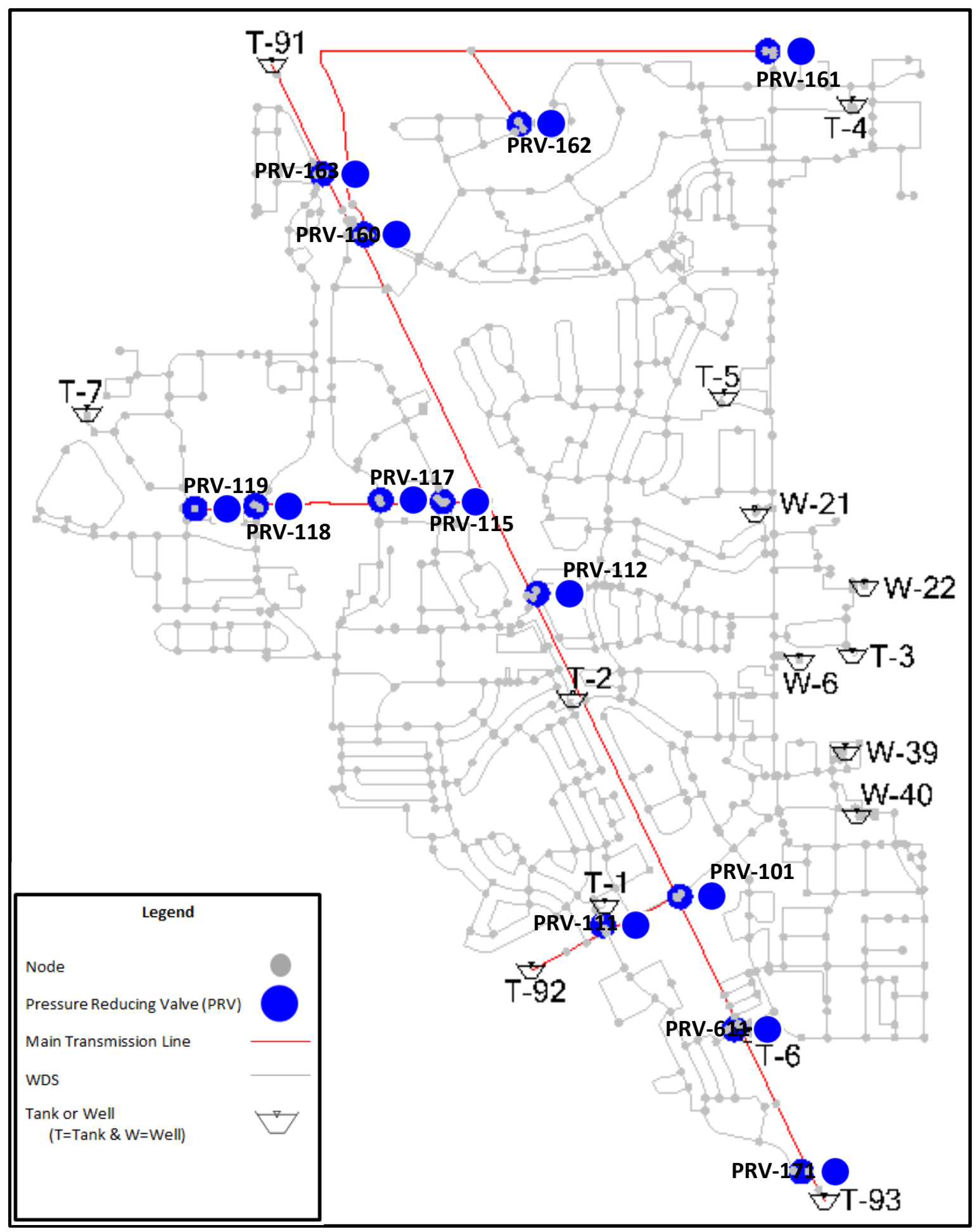

Figure 17: Water Distribution System of "the CITY" 


\subsection{Scenarios}

\subsubsection{Scenario 1: Steady State with Max Daily Demand and Cc=50\%}

Scenario 1 represents steady state conditions where demand and pump pattern are fixed. Under these conditions, a node's representativeness is constant because the system hydraulics do not change. The scenario does not accurately represent a real life scenario because the demand throughout a 24 hour duration typically fluctuates with people's changing water use. The coverage criterion is $50 \%$ for scenario 1-7.

\subsubsection{Scenario 2-7: Extended Period Simulation with $\mathrm{Cc}=50 \%$ and Pattern 2.0, 3.0, 4.0, 5.0, 6.0, and 7.0}

Scenarios 2-7 are more realistic analogs because water distribution systems run under extended periods of unsteady hydraulic conditions. The different patterns simulate varying seasons and alternate usage schedules. They are used to determine how temporal distribution may affect the optimal locations of the monitoring stations. A node's representativeness is more difficult to evaluate in these scenarios because they change with time, e.g. hourly. Important characteristics to examine with the demand patterns are the mean and standard deviations. All the means are 1.0 but the standard deviations vary considerably. This means that the temporal distribution fluctuates which may alter the demand coverage ratio of the monitoring stations. The higher the standard deviation, the more the node demand varies which can easily be seen in Figure 16 as one compares demand pattern 6.0 to 7.0. The standard deviations for pattern 6.0 and 7.0 are 0.97 and 0.36 respectively and pattern 6.0 clearly varies more than pattern 7.0.

\subsubsection{Scenario 8: Max Daily Demand and Pattern 2.0 with $\mathrm{Cc}=25 \%, 50 \%$, and $75 \%$}

This scenario demonstrates how the changing coverage criterion will affect the location and coverage ratio of monitoring stations for steady and unsteady state conditions. The coverage criterion is important to examine because if a contaminant is 
highly concentrated and dangerous in small doses, then a lower coverage criterion may be used to locate potentially contaminated locations. Note that the coverage criterion does not affect the demand pattern.

\subsubsection{Scenario 9: A Coverage Ratio of 95\% is Desired Using Pattern 2.0}

This scenario demonstrates a city requesting to have $95 \%$ coverage of their WDS. For this particular city, funds are not the limiting factor so coverage ratio is used. More monitoring stations can be afforded by some cities due to economics or growth and a 95\% coverage ratio adequately protects a city from large outbreaks due to contaminants. The demand pattern 2.0 is used because it represents the most likely pattern of a city.

\subsubsection{Scenario 10: Demand Coverage (DC) vs Demand Coverage Index (DCI) Methods}

The last scenario examines how the demand coverage method compares to the demand coverage index method. The DC method has weaknesses we have already discussed but it is still instructive to examine how the two methods compare. Components to examine are order of the monitoring stations and the demand coverage ratio. 


\subsection{Summarization of Demand Coverage Index Methodology}

This section will include a detailed description of the steps performed in this analysis as well as a simplified example of the steps required in the DCI method. The simplified example is in Table 10 and follows the exact methodology as the DCI method but with 5 nodes as opposed to 619 nodes. The exact process and equations necessary to calculate the DCI and other results can be seen in the steps preceding the example.

1. A trace analysis is employed for all nodes using EPANET 2.0 in WaterCAD to construct a water fraction matrix. The trace analysis uses a source, or trace, node to determine the percent of water contributing to all downstream nodes in the system. The trace analysis must be employed for every node and results will give an output for every hour since the water from the source node needs time to propagate through the system. Also, note a coverage criterion of $50 \%$ is used which means nodes with $50 \%$ or more water contributed to them by the source node can be assumed to represent the same water quality as that source node.

2. WaterCAD outputs are exported to excel. Refer to section VIII, Exporting WaterCAD Results to Excel, for a more detailed description and example. Table 5 shows the results of all trace analyses combined on a table for pattern 2.0 at hour 13. A similar table is created for each hour in the $24 \mathrm{hr}$ duration. The rows in Table 5 represent the source nodes with the columns showing the percent of water contributing to that downstream node.

3. WaterCAD outputs are converted to a more usable form in excel with a coverage criterion of $50 \%$. Since the results are in a percentage, the $\mathrm{Cc}=50$. If the $\mathrm{Cc} \geq$ 50 , then the node is covered and it gets a value of 1 and nodes that are not covered are 
given a 0 . Doing this also allows for an easy calculation of results if one alters the coverage criterion as in scenario 8 . The results with a coverage criterion of $50 \%$ for pattern 2.0 at hour 13 is seen in Table 6.

4. A steady state analysis or extended period simulation for hydraulic analyses is completed using WaterCAD for 7 demand patterns (max, patt 2.0, 3.0, 4.0, 5.0, 6.0, \& 7.0).

5. WaterCAD outputs are exported to excel to be used with the water fraction matrix. The demand at each hour is multiplied by the water fraction matrix for that hour in order to obtain the demand coverage matrix. The total demand is also calculated for every node at every hour. Also, note that the demand coverage will be either the demand from the pattern at that particular hour or 0 depending on if it is covered or not. Table 7 is the demand coverage matrix after being exported to excel. The demand for demand pattern 2.0 can be seen by the orange highlighted section and the total demand for every node can be seen by the yellow highlighted section. A similar table will be created for every hour, 0-24.

6. All hours of demand coverage are combined on a single table and a demand coverage ranking of the demand coverage matrix is added. This allows for a better understanding of which nodes are temporally important throughout the 24 hour duration. Table 8 shows how this set of data is organized.

7. The total demand coverage index (DCI) is calculated by first determining the total demand coverage (TDC), accumulation of demand coverage ranking (ADCR), and normalized cumulative demand coverage ranking (NCDCR) for the full 24 hour duration. The TDC is the summation of all demand coverages for a single node. The ADCR is the 
summation of the demand coverage rankings for a single node and is represented by the equation below. The NCDCR is calculated by dividing the ADCR by the minimum ADCR of all the nodes. The minimum for the figure below is 37 so for node J8205, the NCDCR is $1453 / 37=39 \cdot 27$. DCI is finally calculated for each node based on the below equations.

$$
\begin{array}{cc}
T D C=\sum_{k=0}^{k} D C_{k} & A D C R=\sum_{k=0}^{k} D C R_{k} \\
N C D C R=\frac{T D C}{A D C R_{\min }} & D C I=\frac{T D C}{A D C R}
\end{array}
$$

Note, Table 8 and 9 show hr 0-8 for simplification but hr 9-24 are also included. Add a ranking for the total DCI to determine the nodes with the highest DCI. Table 9 shows the completed results for the final step in the demand coverage index method.

The Demand Coverage Index method will now be observed in a simplified example which is seen in Table 10. The example has 4 demand patterns, each representing 6 hours for a total duration of 24 hours. It gives results for both the Demand Coverage method, where the total demand coverage (TDC) is maximized, as well as the Demand Coverage Index method, where the demand coverage index (DCI) is maximized.

The example shows a formatted results table after the trace and hydraulic analysis is exported to excel and reorganized. Therefore, the example shows a results table for step 6 and 7 and skips 1-5 because those involved exporting WaterCAD results and reformatting them into excel. The important information to examine in Table 10 is the results and how they are calculated and interpreted.

Based on the Demand Coverage method, the best location to put a node is node 3 because the total demand coverage is the highest, 105 units. However, this does not take into account the change in representativeness that occurs throughout the 24 hour time 
period. Node 3 best reflects the water quality for the first $6 \mathrm{hrs}$ as seen by the demand coverage ranking (DCR) of 1 for pattern 1 and node 4 best reflects the water quality for the remaining $18 \mathrm{hrs}$. Therefore, node 4 has a better representativeness than node 3 even though node 3 has a slightly higher TDC. The optimal location of the monitoring station should be node 4, not node 3 , and this weakness in the DC method is due to the fact that it ignores the temporal distribution and only takes into account the demand covered. The Demand Coverage Index method is the best indicator to pinpoint the optimal locations based on the temporal distribution and the total demand covered by a monitoring station. 
Table 5: Water Fraction Matrix for Pattern 2.0 at $\mathrm{Hr} 13$

\begin{tabular}{|c|c|c|c|c|c|c|c|c|c|}
\hline 4 & A & $B D$ & $\mathrm{BE}$ & BF & $B G$ & $\mathrm{BH}$ & $\mathrm{BI}$ & BJ & BK \\
\hline 1 & & J8205 & 38200 & 38070 & $J 8065$ & 38060 & 38055 & 38050 & $\mathrm{~J} 8045$ \\
\hline 2 & J8205 & 100 & 0 & 0 & 0 & 0 & 0 & 0 & 100 \\
\hline 3 & J8200 & 0 & 100 & 0 & 0 & 0 & 0 & 0 & 0 \\
\hline 4 & J8070 & 0 & 0 & 100 & 100 & 100 & 0 & 0 & 0 \\
\hline 5 & J8065 & 0 & 0 & 0 & 100 & 100 & 0 & 0 & 0 \\
\hline 6 & J8060 & 0 & 0 & 0 & 0 & 100 & 0 & 0 & 0 \\
\hline 7 & J8055 & 100 & 0 & 0 & 0 & 0 & 100 & 100 & 100 \\
\hline 8 & J8050 & 100 & 0 & 0 & 0 & 0 & 0 & 100 & 100 \\
\hline 9 & J8045 & 0 & 0 & 0 & 0 & 0 & 0 & 0 & 100 \\
\hline 10 & J8040 & 0 & 0 & 0 & 0 & 0 & 0 & 0 & 0 \\
\hline 11 & J8035 & 0 & 0 & 0 & 0 & 0 & 0 & 0 & 0 \\
\hline 12 & J8030 & 0 & 0 & 0 & 0 & 0 & 0 & 0 & 0 \\
\hline 13 & J8025 & 0 & 84.4 & 0 & 0 & 0 & 0 & 0 & 0 \\
\hline 14 & J8020 & 0 & 84.4 & 0 & 0 & 0 & 0 & 0 & 0 \\
\hline
\end{tabular}

Table 6: Coverage of Pattern 2.0 at Hr 13

\begin{tabular}{|c|c|c|c|c|c|c|c|c|c|}
\hline 4 & A & BD & $\mathrm{BE}$ & BF & BG & $\mathrm{BH}$ & $\mathrm{BI}$ & BJ & BK \\
\hline 654 & $\mathrm{Cc}=$ & \multirow{2}{*}{38205} & \multirow{2}{*}{$J 8200$} & \multirow{2}{*}{38070} & \multirow{2}{*}{38065} & \multirow{2}{*}{38060} & \multirow{2}{*}{$J 8055$} & \multirow{2}{*}{38050} & \multirow{2}{*}{$\mathrm{J} 8045$} \\
\hline 655 & 50 & & & & & & & & \\
\hline 656 & J8205 & 1 & 0 & 0 & 0 & 0 & 0 & 0 & 1 \\
\hline 657 & $\mathrm{~J} 8200$ & 0 & 1 & 0 & 0 & 0 & 0 & 0 & 0 \\
\hline 658 & $\mathrm{~J} 8070$ & 0 & 0 & 1 & 1 & 1 & 0 & 0 & 0 \\
\hline 659 & J8065 & 0 & 0 & 0 & 1 & 1 & 0 & 0 & 0 \\
\hline 660 & $\mathrm{~J} 8060$ & 0 & 0 & 0 & 0 & 1 & 0 & 0 & 0 \\
\hline 661 & J8055 & 1 & 0 & 0 & 0 & 0 & 1 & 1 & 1 \\
\hline 662 & $\mathrm{~J} 8050$ & 1 & 0 & 0 & 0 & 0 & 0 & 1 & 1 \\
\hline 663 & J8045 & 0 & 0 & 0 & 0 & 0 & 0 & 0 & 1 \\
\hline 664 & $\mathrm{~J} 8040$ & 0 & 0 & 0 & 0 & 0 & 0 & 0 & 0 \\
\hline 665 & J8035 & 0 & 0 & 0 & 0 & 0 & 0 & 0 & 0 \\
\hline 666 & J8030 & 0 & 0 & 0 & 0 & 0 & 0 & 0 & 0 \\
\hline 667 & $\mathrm{~J} 8025$ & 0 & 1 & 0 & 0 & 0 & 0 & 0 & 0 \\
\hline 668 & $\mathrm{~J} 8020$ & 0 & 1 & 0 & 0 & 0 & 0 & 0 & 0 \\
\hline 669 & J8015 & 0 & 0 & 0 & 0 & 0 & 0 & 0 & 0 \\
\hline 670 & J8010 & 0 & 0 & 0 & 0 & 0 & 0 & 0 & 0 \\
\hline 671 & J8005 & 0 & 0 & 0 & 0 & 0 & 0 & 0 & 0 \\
\hline
\end{tabular}


Table 7: Demand Coverage Matrix for Pattern 2.0 at Hr 13

\begin{tabular}{|c|c|c|c|c|c|c|c|c|c|}
\hline 4 & A & $s x$ & SY & $\mathrm{SZ}$ & TA & $\mathrm{TB}$ & TC & TD & AAF \\
\hline 1308 & Demand & 52 & 18 & 40 & 20 & 8 & 8 & 31 & \\
\hline 1310 & \multirow{2}{*}{ MS } & \multicolumn{7}{|c|}{ Nodes } & \\
\hline 1311 & & J3930 & J3925 & $J 3920$ & J3915 & J3910 & J3905 & J3900 & Total \\
\hline 1312 & J8205 & 52 & 18 & 40 & 20 & 8 & 8 & 31 & 548 \\
\hline 1313 & $J 8200$ & 0 & 0 & 0 & 0 & 0 & 0 & 0 & 22 \\
\hline 1314 & $\mathrm{~J} 8070$ & 0 & 0 & 0 & 0 & 0 & 0 & 0 & 153 \\
\hline 1315 & J8065 & 0 & 0 & 0 & 0 & 0 & 0 & 0 & 161 \\
\hline 1316 & $J 8060$ & 0 & 0 & 0 & 0 & 0 & 0 & 0 & 161 \\
\hline 1317 & J8055 & 52 & 18 & 40 & 20 & 8 & 8 & 31 & 548 \\
\hline 1318 & $J 8050$ & 52 & 18 & 40 & 20 & 8 & 8 & 31 & 548 \\
\hline 1319 & J8045 & 52 & 18 & 40 & 20 & 8 & 8 & 31 & 548 \\
\hline 1320 & $J 8040$ & 0 & 0 & 0 & 0 & 0 & 0 & 0 & 0 \\
\hline 1321 & J8035 & 0 & 0 & 0 & 0 & 0 & 0 & 0 & 0 \\
\hline 1322 & $\mathrm{~J} 8030$ & 0 & 0 & 0 & 0 & 0 & 0 & 0 & 22 \\
\hline 1323 & $J 8025$ & 0 & 0 & 0 & 0 & 0 & 0 & 0 & 0 \\
\hline 1324 & $\mathrm{~J} 8020$ & 0 & 0 & 0 & 0 & 0 & 0 & 0 & 0 \\
\hline 1325 & J8015 & 0 & 0 & 0 & 0 & 0 & 0 & 0 & 192 \\
\hline 1326 & $\mathrm{~J} 8010$ & 0 & 0 & 0 & 0 & 0 & 0 & 0 & 192 \\
\hline 1327 & $J 8005$ & 0 & 0 & 0 & 0 & 0 & 0 & 0 & 192 \\
\hline 1355 & J6061 & 0 & 0 & 0 & 0 & 0 & 0 & 0 & 160 \\
\hline
\end{tabular}

Table 8: Demand Coverage Matrix for Pattern 2.0

\begin{tabular}{|c|c|c|c|c|c|c|c|c|c|c|}
\hline 4 & A & B & C & D & E & $\mathrm{F}$ & G & H & I & J \\
\hline 1 & & Hour & $J 8205$ & $J 8200$ & $J 8070$ & J8065 & $J 8060$ & J8055 & $J 8050$ & $J 8045$ \\
\hline 2 & \multirow{9}{*}{$\begin{array}{l}\text { Demand } \\
\text { Coverage }\end{array}$} & 0 & 0 & 0 & 0 & 0 & 0 & 0 & 0 & 0 \\
\hline 3 & & 1 & 12 & 0 & 0 & 0 & 3 & 5 & 10 & 14 \\
\hline 4 & & 2 & 47 & 0 & 10 & 11 & 11 & 29 & 34 & 47 \\
\hline 5 & & 3 & 122 & 0 & 24 & 65 & 65 & 99 & 99 & 122 \\
\hline 6 & & 4 & 313 & 0 & 138 & 138 & 138 & 253 & 261 & 313 \\
\hline 7 & & 5 & 845 & 0 & 346 & 346 & 348 & 807 & 845 & 845 \\
\hline 8 & & 6 & 1071 & 18 & 431 & 435 & 435 & 1071 & 1071 & 1071 \\
\hline 9 & & 7 & 855 & 41 & 371 & 371 & 371 & 855 & 855 & 855 \\
\hline 10 & & 8 & 673 & 31 & 320 & 320 & 320 & 646 & 646 & 673 \\
\hline 27 & \multirow{9}{*}{ Rank } & 0 & 450 & 450 & 450 & 450 & 450 & 450 & 450 & 450 \\
\hline 28 & & 1 & 75 & 554 & 554 & 554 & 339 & 216 & 93 & 56 \\
\hline 29 & & 2 & 63 & 574 & 317 & 296 & 296 & 120 & 96 & 63 \\
\hline 30 & & 3 & 54 & 595 & 322 & 130 & 130 & 76 & 76 & 54 \\
\hline 31 & & 4 & 46 & 595 & 135 & 135 & 135 & 68 & 64 & 46 \\
\hline 32 & & 5 & 40 & 596 & 117 & 117 & 115 & 45 & 40 & 40 \\
\hline 33 & & 6 & 40 & 571 & 130 & 127 & 127 & 40 & 40 & 40 \\
\hline 34 & & 7 & 42 & 490 & 121 & 121 & 121 & 42 & 42 & 42 \\
\hline 35 & & 8 & 42 & 488 & 106 & 106 & 106 & 46 & 46 & 42 \\
\hline
\end{tabular}


Table 9: Results Table for Pattern 2.0

\begin{tabular}{|c|c|c|c|c|c|c|c|c|c|c|}
\hline & \multirow{2}{*}{ Hour } & \multicolumn{9}{|c|}{ Nodes } \\
\hline & & J8205 & $J 8200$ & $J 8070$ & J8065 & $J 8060$ & J8055 & $J 8050$ & J8045 & J8040 \\
\hline \multirow{9}{*}{$\begin{array}{l}\text { Demand } \\
\text { Coverage }\end{array}$} & 0 & 0 & 0 & 0 & 0 & 0 & 0 & 0 & 0 & 0 \\
\hline & 1 & 12 & 0 & 0 & 0 & 3 & 5 & 10 & 14 & 0 \\
\hline & 2 & 47 & 0 & 10 & 11 & 11 & 29 & 34 & 47 & 0 \\
\hline & 3 & 122 & 0 & 24 & 65 & 65 & 99 & 99 & 122 & 0 \\
\hline & 4 & 313 & 0 & 138 & 138 & 138 & 253 & 261 & 313 & 0 \\
\hline & 5 & 845 & 0 & 346 & 346 & 348 & 807 & 845 & 845 & 0 \\
\hline & 6 & 1071 & 18 & 431 & 435 & 435 & 1071 & 1071 & 1071 & 0 \\
\hline & 7 & 855 & 41 & 371 & 371 & 371 & 855 & 855 & 855 & 0 \\
\hline & 8 & 673 & 31 & 320 & 320 & 320 & 646 & 646 & 673 & 0 \\
\hline \multirow{9}{*}{$\begin{array}{l}\text { Demand } \\
\text { Coverage } \\
\text { Ranking }\end{array}$} & 0 & 450 & 450 & 450 & 450 & 450 & 450 & 450 & 450 & 450 \\
\hline & 1 & 75 & 554 & 554 & 554 & 339 & 216 & 93 & 56 & 554 \\
\hline & 2 & 63 & 574 & 317 & 296 & 296 & 120 & 96 & 63 & 574 \\
\hline & 3 & 54 & 595 & 322 & 130 & 130 & 76 & 76 & 54 & 595 \\
\hline & 4 & 46 & 595 & 135 & 135 & 135 & 68 & 64 & 46 & 595 \\
\hline & 5 & 40 & 596 & 117 & 117 & 115 & 45 & 40 & 40 & 596 \\
\hline & 6 & 40 & 571 & 130 & 127 & 127 & 40 & 40 & 40 & 601 \\
\hline & 7 & 42 & 490 & 121 & 121 & 121 & 42 & 42 & 42 & 601 \\
\hline & 8 & 42 & 488 & 106 & 106 & 106 & 46 & 46 & 42 & 601 \\
\hline \multirow{5}{*}{ Results } & TDC & 14131 & 256 & 5701 & 5755 & 5760 & 13958 & 14014 & 14133 & 0 \\
\hline & ADCR & 1453 & 13680 & 4074 & 3844 & 3627 & 1704 & 1548 & 1434 & 14744 \\
\hline & NCDCR & 39.27027 & 369.72973 & 110.1081 & 103.8919 & 98.02703 & 46.05405 & 41.83784 & 38.75676 & 398.4865 \\
\hline & $\mathrm{DCl}$ & 359.8396 & 0.6923977 & 51.77639 & 55.39412 & 58.75931 & 303.0786 & 334.9599 & 364.659 & 0 \\
\hline & rank & 41 & 572 & 126 & 120 & 115 & 46 & 44 & 40 & 607 \\
\hline
\end{tabular}


Table 10: Example of Demand Coverage and Demand Coverage Index Methods

\begin{tabular}{|c|ccccc|}
\hline \multirow{3}{*}{ Patterns } & \multicolumn{5}{|c|}{ Nodes } \\
\cline { 2 - 6 } & 1 & 2 & 3 & 4 & 5 \\
\hline \multirow{2}{*}{1} & 10 & 15 & 40 & 20 & 5 \\
& 4 & 3 & 1 & 2 & 5 \\
\hline \multirow{2}{*}{2} & 5 & 10 & 20 & 25 & 5 \\
& 4 & 3 & 2 & 1 & 4 \\
\hline \multirow{3}{*}{3} & 10 & 15 & 20 & 25 & 15 \\
& 4 & 3 & 2 & 1 & 3 \\
\hline \multirow{2}{*}{4} & 10 & 10 & 25 & 30 & 10 \\
& 3 & 3 & 2 & 1 & 3 \\
\hline TDC & 35 & 50 & 105 & 100 & 35 \\
ADCR & 15 & 12 & 7 & 5 & 15 \\
NCDCR & 3.0 & 2.4 & 1.4 & 1.0 & 3.0 \\
DCI & 2.33 & 4.17 & 15 & 20 & 2.33 \\
\hline
\end{tabular}

Keys to Table 5:

$$
\begin{gathered}
40 \\
1
\end{gathered} \longrightarrow \text { Demand Coverage (GPM) }
$$

TDC: Total Demand Coverage

ADCR: Accumulated Demand Coverage Ranking

NCDCR: Normalized Cumulative Demand Coverage Ranking

DCl: Demand Coverage Index 


\subsection{Optimization Procedure}

The results are optimized to maximize DCI with the minimum number of monitoring stations. The optimization procedure is meant to maximize coverage of the water distribution system with the minimum number of monitoring stations. Many different optimization methods have been utilized on the DCI method including an integer programming method (Lee and Deininger, 1992), a greedy heuristic based algorithm (Kumar et al, 1997), and a genetic algorithm (Al-Zahrani and Moied, 2001). This study uses a simple trial and error method where the total DCI of similarly covered nodes are compared to one another and the most optimal node is picked. The method is presented below:

1. Total DCI is calculated as DCI of source node plus DCI of nodes being covered by this source node. Table 12 shows the individual DCI as well as the total DCI of all source nodes.

2. The node with the highest total DCI is chosen to be a monitoring station but ensure that the same nodes are not covered by previous monitoring stations because a node cannot be covered twice. For example, in Table 11 the nodes covered by J8205 and J8050 are covered by J8055 in addition to an extra node (J8055) so nodes J8205 and J8050 are inferior monitoring stations and are represented by red numbers in Table 12 . The red nodes represent nodes that are already covered by an upstream monitoring station.

If the potential monitoring station covers the same nodes, subtract these already covered nodes and calculate the new total DCI, or adjusted DCI, for that source node. There are 
no adjusted DCIs in the top monitoring stations in Table 12 because the water distribution system is large enough that the coverage does not overlap.

3. Step 2 is repeated until the proper number of monitoring stations are determined.

Table 11: Comparison of Similarly Covered Source Nodes

\begin{tabular}{|c|c|c|c|}
\hline Node & J8205 & J8055 & $J 8050$ \\
\hline \multirow[t]{2}{*}{ TDC } & 6722 & 6651 & 6659 \\
\hline & 717 & 963 & 932 \\
\hline \multirow{2}{*}{$\begin{array}{c}\text { ADCR } \\
\text { DCl }\end{array}$} & $(2.8)$ & (3.7) & (3.6) \\
\hline & 2438 & 1796 & 1858 \\
\hline \multirow{33}{*}{$\begin{array}{l}\text { Nodes } \\
\text { Covered }\end{array}$} & \multirow[t]{3}{*}{8205} & 8205 & 8205 \\
\hline & & 8055 & \\
\hline & & 8050 & 8050 \\
\hline & 8045 & 8045 & 8045 \\
\hline & 5570 & 5570 & 5570 \\
\hline & 4130 & 4130 & 4130 \\
\hline & 4125 & 4125 & 4125 \\
\hline & 4100 & 4100 & 4100 \\
\hline & 4095 & 4095 & 4095 \\
\hline & 4090 & 4090 & 4090 \\
\hline & 4065 & 4065 & 4065 \\
\hline & 4060 & 4060 & 4060 \\
\hline & 4055 & 4055 & 4055 \\
\hline & 4050 & 4050 & 4050 \\
\hline & 4045 & 4045 & 4045 \\
\hline & 4040 & 4040 & 4040 \\
\hline & 4035 & 4035 & 4035 \\
\hline & 4005 & 4005 & 4005 \\
\hline & 4000 & 4000 & 4000 \\
\hline & 3995 & 3995 & 3995 \\
\hline & 3930 & 3930 & 3930 \\
\hline & 3925 & 3925 & 3925 \\
\hline & 3920 & 3920 & 3920 \\
\hline & 3915 & 3915 & 3915 \\
\hline & 3910 & 3910 & 3910 \\
\hline & 3905 & 3905 & 3905 \\
\hline & 3900 & 3900 & 3900 \\
\hline & 3895 & 3895 & 3895 \\
\hline & 3890 & 3890 & 3890 \\
\hline & 3885 & 3885 & 3885 \\
\hline & 3880 & 3880 & 3880 \\
\hline & 3875 & 3875 & 3875 \\
\hline & 3870 & 3870 & 3870 \\
\hline
\end{tabular}


Table 12: Final Output for Optimization Procedure for Pattern 2.0

\begin{tabular}{|c|c|c|c|c|c|}
\hline $\begin{array}{c}\text { Monitoring } \\
\text { Station \# }\end{array}$ & Node & $\begin{array}{c}\text { \# of } \\
\text { Nodes } \\
\text { Covered }\end{array}$ & $\begin{array}{c}\text { Individual } \\
\text { DCI }\end{array}$ & Total DCl & $\begin{array}{l}\text { Adjusted } \\
\text { DCl }\end{array}$ \\
\hline 1 & J3455 & 68 & 960.8 & 3969.7 & \\
\hline 2 & $\mathrm{~J} 3840$ & 54 & 727.8 & 2953.2 & \\
\hline 3 & $J 5860$ & 30 & 717.5 & 2900.4 & \\
\hline \multirow[t]{2}{*}{4} & $\mathrm{~J} 8055$ & 33 & 303.1 & 2681.2 & \\
\hline & J8050 & 32 & 335.0 & 2378.1 & \\
\hline \multirow[t]{5}{*}{5} & $J 5875$ & 46 & 654.0 & 2236.4 & \\
\hline & J8205 & 31 & 359.8 & 2043.2 & \\
\hline & J5820 & 39 & 462.3 & 1979.2 & \\
\hline & $\mathrm{J} 5825$ & 33 & 217.4 & 1804.5 & \\
\hline & $\mathrm{J} 8045$ & 30 & 364.7 & 1683.3 & \\
\hline 6 & $J 5325$ & 29 & 643.0 & 1256.1 & 1253.9 \\
\hline 7 & $J 3000$ & 30 & 298.0 & 1198.5 & \\
\hline 8 & $J 4520$ & 32 & 300.4 & 1106.7 & \\
\hline 9 & $\mathrm{~J} 4030$ & 26 & 284.6 & 1010.9 & 1001.2 \\
\hline \multirow[t]{2}{*}{10} & $J 6005$ & 13 & 502.6 & 702.9 & 646.2 \\
\hline & J3375 & 10 & 105.1 & 626.1 & 119.7 \\
\hline \multirow[t]{7}{*}{11} & $\mathrm{~J} 5175$ & 34 & 8.9 & 620.6 & \\
\hline & $J 5865$ & 8 & 152.6 & 596.5 & \\
\hline & $J 4325$ & 12 & 29.6 & 585.2 & \\
\hline & $\mathrm{J} 4330$ & 11 & 28.8 & 583.5 & \\
\hline & $\mathrm{J} 5870$ & 17 & 10.1 & 553.4 & \\
\hline & $\mathrm{J} 5415$ & 16 & 133.3 & 543.4 & \\
\hline & $\mathrm{J} 5855$ & 24 & 126.8 & 539.5 & \\
\hline 12 & $J 5085$ & 18 & 298.2 & 496.1 & 496.0 \\
\hline \multirow[t]{4}{*}{13} & $J 5475$ & 27 & 251.8 & 469.7 & 393.0 \\
\hline & J5495 & 15 & 5.2 & 463.5 & \\
\hline & $J 5490$ & 15 & 7.6 & 463.5 & \\
\hline & $\mathrm{J} 4310$ & 7 & 181.6 & 443.9 & \\
\hline \multirow[t]{3}{*}{14} & $\mathrm{~J} 5845$ & 23 & 122.8 & 406.8 & 388.6 \\
\hline & $\mathrm{J} 4490$ & 15 & 10.1 & 405.8 & 82.2 \\
\hline & $\mathrm{J} 3170$ & 22 & 73.6 & 400.0 & 64.8 \\
\hline 15 & J3210 & 14 & 71.6 & 398.7 & 380.4 \\
\hline
\end{tabular}




\subsection{Exporting WaterCAD Results to Excel}

The trace percent and demand data from WaterCAD needs to be exported into an excel file in order to perform an analysis. The first step is to modify the flex table for the junctions to include trace percent and demand when performing the steady state or extended period simulations. This is done by using the edit feature at the top of the flex table. All categories should be removed in order to limit the amount of data being analyzed and to speed up the exporting process. The categories of importance are trace (\%) when performing the trace analysis and demand (gpm) when performing the steady state or extended period simulation analysis. For the trace percent, all time steps are required to do a proper analysis. This is achieved at the top of the flextable by looking at the results options and selecting report all time steps. A report is generated but the format does not allow for proper analysis and must be exported to an excel file. Under file and export document, a few options are available to export the document but an excel file is the desired format. The WaterCAD output will look similar to Table 13.

In order to efficiently format the data, macros are necessary to rearrange the data into a useful form. Excel makes creating macros simple by selecting record macro under the developer tab and inputting a desired keystroke for that particular macro. The desired transferring of data is completed and then the stop macro button is selected. That macro will now occur every time the associated keystroke is pressed. 
Table 13: WaterCAD Output for Trace \% and Demand at Hour 12

\begin{tabular}{|c|c|c|c|}
\hline \multicolumn{2}{|c|}{$\begin{array}{l}\text { Current Time: } 12.000 \\
\text { hours }\end{array}$} & \multicolumn{2}{|c|}{$\begin{array}{l}\text { Current Time: } 12.000 \\
\text { hours }\end{array}$} \\
\hline \multirow[t]{2}{*}{ Label } & $\begin{array}{c}\text { Trace } \\
\text { (Calculated) }\end{array}$ & Label & $\begin{array}{l}\text { Demand } \\
\text { (gpm) }\end{array}$ \\
\hline & & j3445 & 10 \\
\hline J3445 & 59.7 & 33440 & 1 \\
\hline $\mathrm{J} 3440$ & 21.4 & J3435 & 4 \\
\hline $\mathrm{J} 3435$ & 53.9 & ر3430 & 17 \\
\hline $\mathrm{J} 3430$ & 0.0 & J3425 & 9 \\
\hline 33425 & 3.4 & J3420 & 1 \\
\hline 33420 & 71.8 & j3415 & 22 \\
\hline $\mathrm{J} 3415$ & 71.9 & ر3410 & 14 \\
\hline 13410 & 71.8 & J3405 & 12 \\
\hline J3405 & 73.2 & 13400 & 4 \\
\hline 33400 & 72.0 & ر3395 & 2 \\
\hline J3395 & 71.8 & |33390 & 47 \\
\hline J3390 & 100.0 & J3385 & 17 \\
\hline J3385 & 81.8 & ر3380 & 3 \\
\hline J3380 & 71.8 & |33375 & 14 \\
\hline J3375 & 71.8 & |33370 & 5 \\
\hline J3370 & 71.8 & J3365 & 6 \\
\hline J3365 & 71.8 & J3360 & 10 \\
\hline J3360 & 71.8 & ر3355 & 3 \\
\hline J3355 & 0.0 & |33350 & 6 \\
\hline J3350 & 0.0 & J3340 & 4 \\
\hline J3340 & 0.0 & J3338 & 8 \\
\hline J3338 & 0.0 & |3335 & 4 \\
\hline J3335 & 0.0 & |3330 & 4 \\
\hline 33330 & 0.0 & 13325 & 8 \\
\hline
\end{tabular}

An example macro is the trace analysis to water fraction matrix transformation.

Table 14 is the WaterCAD output of a trace analysis for node J8205 after being exported to excel. The output contains the trace analysis for hour 0-24 but only hr 13 is seen in the table. This data needs to be arranged into a more accessible table; therefore, a macro will be used due to the large amounts of data and repetitious nature of the transformation. The macro takes the WaterCAD output arranged in columns and transforms them into rows 
with each hour getting its own tab in excel. Each WaterCAD output is only for one node however so the macro has to be used 619 times. Table 15 shows the results of the macro after all nodes have been transferred. This is the water fraction matrix for hr 13 but one is created for each hour. The highlighted region of the tables show how the macro functions for hr 13 .

Table 14: WaterCAD Output in Excel (Pre-Macro)

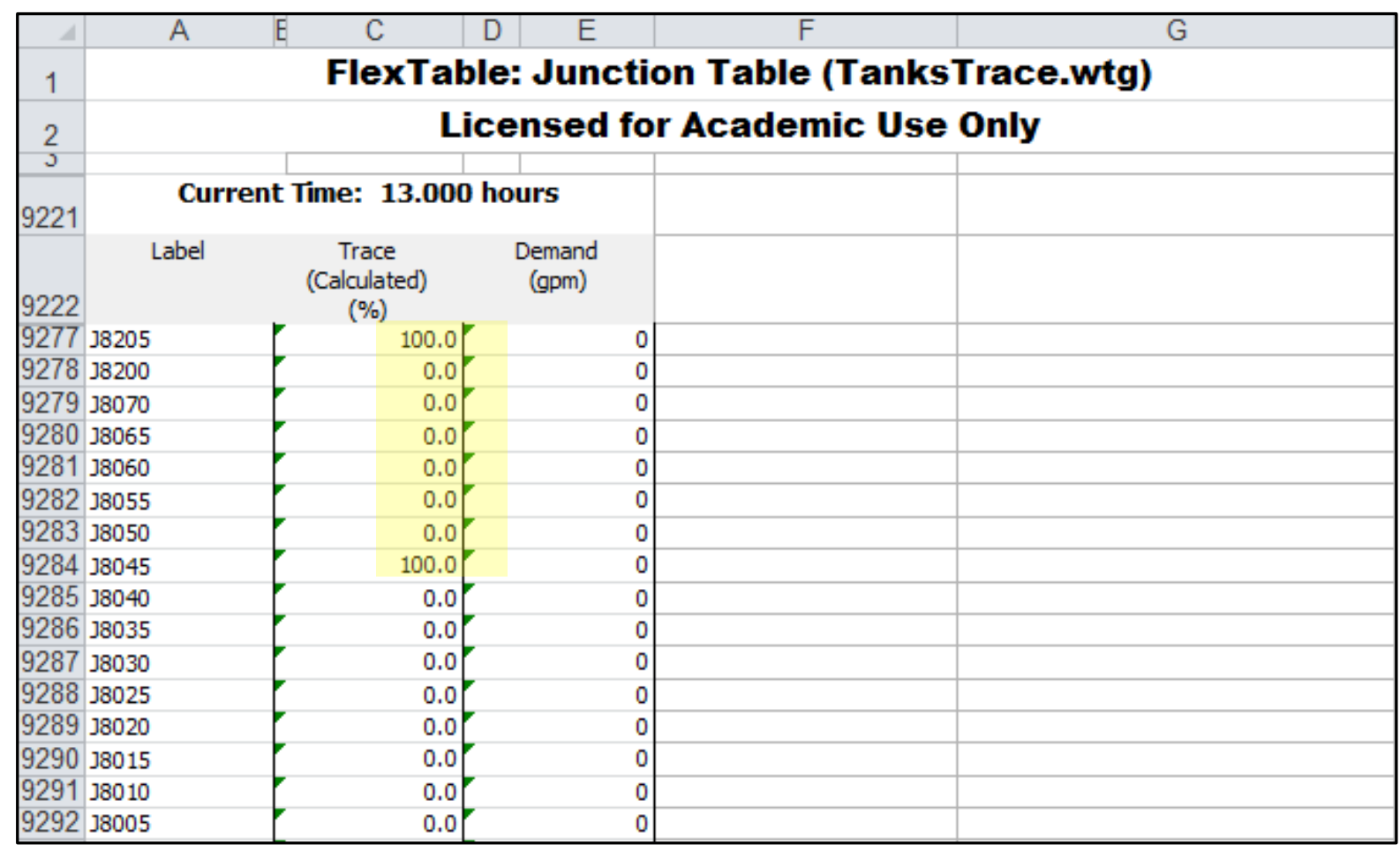


Table 15: Water Fraction Matrix for Hr 13 (Post-Macro)

\begin{tabular}{|c|c|c|c|c|c|c|c|c|c|}
\hline$\not$ & A & BD & $\mathrm{BE}$ & BF & $B G$ & $\mathrm{BH}$ & $\mathrm{BI}$ & BJ & BK \\
\hline 1 & & 38205 & 38200 & 38070 & 38065 & $\mathrm{~J} 8060$ & 38055 & $\mathrm{~J} 8050$ & 38045 \\
\hline 2 & J8205 & 100 & 0 & 0 & 0 & 0 & 0 & 0 & 100 \\
\hline 3 & $J 8200$ & 0 & 100 & 0 & 0 & 0 & 0 & 0 & 0 \\
\hline 4 & J8070 & 0 & 0 & 100 & 100 & 100 & 0 & 0 & 0 \\
\hline 5 & J8065 & 0 & 0 & 0 & 100 & 100 & 0 & 0 & 0 \\
\hline 6 & J8060 & 0 & 0 & 0 & 0 & 100 & 0 & 0 & 0 \\
\hline 7 & J8055 & 100 & 0 & 0 & 0 & 0 & 100 & 100 & 100 \\
\hline 8 & $J 8050$ & 100 & 0 & 0 & 0 & 0 & 0 & 100 & 100 \\
\hline 9 & J8045 & 0 & 0 & 0 & 0 & 0 & 0 & 0 & 100 \\
\hline 10 & J8040 & 0 & 0 & 0 & 0 & 0 & 0 & 0 & 0 \\
\hline 11 & J8035 & 0 & 0 & 0 & 0 & 0 & 0 & 0 & 0 \\
\hline 12 & J8030 & 0 & 0 & 0 & 0 & 0 & 0 & 0 & 0 \\
\hline 13 & J8025 & 0 & 84.4 & 0 & 0 & 0 & 0 & 0 & 0 \\
\hline 14 & J8020 & 0 & 84.4 & 0 & 0 & 0 & 0 & 0 & 0 \\
\hline
\end{tabular}

Problems that may occur with the macro are too much data to format and the data is automatically converted to text. The first problem is addressed by dividing the macro into several macros to reduce how much data is changed under a specific keystroke. The trace percent reformatting requires the use of 4 keystrokes to complete the macro. The text problem can be solved by changing all values formatted as text to numerical values by hand. The text values created problems because calculations cannot be done with the text data so the analysis can be temporarily delayed by this problem. 


\subsection{Summary and Discussion of Results}

\subsubsection{Scenario 1: Max Daily Demand}

The results for scenario 1 and 2-7 will be presented together due to the many similarities.

\subsubsection{Scenario 2-7 Demand Pattern 2.0, 3.0, 4.0, 5.0, 6.0, \& 7.0}

The optimal locations of the monitoring stations for max daily demand, demand pattern 2.0, 3.0, 4.0, 5.0, 6.0, \& 7.0 are identical; however, the order of importance is slightly different for several of the patterns. This is only relevant if funding is limited and fewer than 15 monitoring stations will be built. Tables 16-22 give a detailed look at the monitoring stations and corresponding coverage ratio for the desired number of monitoring stations.

The result verifies that the temporal distribution of the different patterns does not affect the representativeness of a significant node. A monitoring station location will be the same regardless if the peak demand is in the middle of the day or if it peaks in the morning and at night. This is an ideal result because throughout a year, the demand pattern may change with seasons and varying usage schedule but this method shows that the location of the monitoring stations will remain the same and provide significant monitoring capabilities.

The coverage ratios vary from about $88 \%$ to $91 \%$ which means about $90 \%$ of the total network demand can be monitored depending on the demand pattern being used. This is an important result because if one demand pattern had a coverage ratio that is significantly less, then the monitoring stations would be significantly less effective for that day or season. This would be a huge weakness that could be exploited to disrupt or infect the whole system without detection. Depending on the funding available for a 
30,000 to 40,000 resident city, the number of monitoring stations may differ and Figure 18 shows the results for the top 15 monitoring stations. Figure 19-21 show the individual coverage of these monitoring stations and Figure 22 shows the entire coverage from the 15 monitoring stations.

The 15 stations cover 455 nodes of the possible 619 , which is $73.5 \%$ of the nodes.

There appears to be a significant number of nodes that are not covered but many of the remaining nodes have a DCI of less than 5 . Remember, none of the nodes are covered twice, but rather the higher ranked monitoring station will cover it and the other remaining nodes will not.

Table 16: Summary of Results Using the DCI Method and Max Daily Demand (Total DCI = 23351.5)

\begin{tabular}{|c|c|c|c|}
\hline $\begin{array}{c}\text { Number } \\
\text { of MS }\end{array}$ & Optimal Locations of MS for Max Daily Demand Pattern & $\begin{array}{c}\text { Total } \\
\text { DCI }\end{array}$ & $\begin{array}{c}\text { Coverage } \\
\text { Ratio }\end{array}$ \\
\hline 1 & 3455 & 3643.1 & 0.1560 \\
2 & 3455,3840 & 6432.9 & 0.2755 \\
3 & $3455,3840,5860$ & 9117.1 & 0.3904 \\
4 & $3455,3840,5860,8055$ & 11579.3 & 0.4959 \\
5 & $3455,3840,5860,8055,5875$ & 13614.3 & 0.5830 \\
6 & $3455,3840,5860,8055,5875,5325$ & 14823.7 & 0.6348 \\
7 & $3455,3840,5860,8055,5875,5325,3000$ & 15956.1 & 0.6833 \\
8 & $3455,3840,5860,8055,5875,5325,3000,4520$ & 17003.7 & 0.7282 \\
9 & $3455,3840,5860,8055,5875,5325,3000,4520,4030$ & 17956.2 & 0.7690 \\
10 & $3455,3840,5860,8055,5875,5325,3000,4520,4030,6005$ & 18592.6 & 0.7962 \\
11 & $3455,3840,5860,8055,5875,5325,3000,4520,4030,6005,5175$ & 19176.4 & 0.8212 \\
12 & $3455,3840,5860,8055,5875,5325,3000,4520,4030,6005,5175,5085$ & 19651.9 & 0.8416 \\
13 & $3455,3840,5860,8055,5875,5325,3000,4520,4030,6005,5175,5085,5475$ & 20038.4 & 0.8581 \\
& $3455,3840,5860,8055,5875,5325,3000,4520,4030,6005,5175,5085,5475$, & & \\
14 & 3210 & 20408.8 & 0.8740 \\
15 & $3455,3840,5860,8055,5875,5325,3000,4520,4030,6005,5175,5085,5475$, & 20772.5 & 0.8896 \\
\hline
\end{tabular}


Table 17: Summary of Results Using the DCI Method and Demand Pattern 2.0 (Total DCI = 24867.8)

\begin{tabular}{|c|c|c|c|}
\hline $\begin{array}{c}\text { Number } \\
\text { of MS }\end{array}$ & Optimal Locations of MS for Demand Pattern 2.0 & $\begin{array}{l}\text { Total } \\
\text { DCI }\end{array}$ & $\begin{array}{c}\text { Coverage } \\
\text { Ratio }\end{array}$ \\
\hline 1 & 3455 & 3969.8 & 0.1596 \\
\hline 2 & 3455,3840 & 6923.0 & 0.2784 \\
\hline 3 & $3455,3840,5860$ & 9823.4 & 0.3950 \\
\hline 4 & $3455,3840,5860,8055$ & 12504.6 & 0.5028 \\
\hline 5 & $3455,3840,5860,8055,5875$ & 14741.0 & 0.5928 \\
\hline 6 & $3455,3840,5860,8055,5875,5325$ & 15994.9 & 0.6432 \\
\hline 7 & $3455,3840,5860,8055,5875,5325,3000$ & 17193.5 & 0.6914 \\
\hline 8 & $3455,3840,5860,8055,5875,5325,3000,4520$ & 18300.2 & 0.7359 \\
\hline 9 & $3455,3840,5860,8055,5875,5325,3000,4520,4030$ & 19026.5 & 0.7651 \\
\hline 10 & $3455,3840,5860,8055,5875,5325,3000,4520,4030,6005$ & 19672.6 & 0.7911 \\
\hline 11 & $3455,3840,5860,8055,5875,5325,3000,4520,4030,6005,5175$ & 20293.2 & 0.8160 \\
\hline 12 & $3455,3840,5860,8055,5875,5325,3000,4520,4030,6005,5175,5085$ & 20789.2 & 0.8360 \\
\hline 13 & $3455,3840,5860,8055,5875,5325,3000,4520,4030,6005,5175,5085,5475$ & 21182.2 & 0.8518 \\
\hline 14 & $3455,3840,5860,8055,5875,5325, \underset{5845}{3000,4520,4030,6005,5175,5085,5475}$ & 21570.8 & 0.8674 \\
\hline 15 & $\begin{array}{c}3455,3840,5860,8055,5875,5325,3000,4520,4030,6005,5175,5085,5475 \\
5845,3210\end{array}$ & 21951.2 & 0.8827 \\
\hline
\end{tabular}

Table 18: Summary of Results Using the DCI Method and Demand Pattern 3.0 (Total DCI = 24109.6)

\begin{tabular}{|c|c|c|c|}
\hline $\begin{array}{c}\text { Number } \\
\text { of MS }\end{array}$ & Optimal Locations of MS for Demand Pattern 3.0 & $\begin{array}{c}\text { Total } \\
\text { DCI }\end{array}$ & $\begin{array}{c}\text { Coverage } \\
\text { Ratio }\end{array}$ \\
\hline 1 & 3455 & 3816.4 & 0.1582 \\
2 & 3455,3840 & 6720.2 & 0.2787 \\
3 & $3455,3840,5860$ & 9475.7 & 0.3930 \\
4 & $3455,3840,5860,8055$ & 12049.5 & 0.4998 \\
5 & $3455,3840,5860,8055,5875$ & 14213.3 & 0.5895 \\
6 & $3455,3840,5860,8055,5875,5325$ & 15440.8 & 0.6404 \\
7 & $3455,3840,5860,8055,5875,5325,3000$ & 16596.1 & 0.6884 \\
8 & $3455,3840,5860,8055,5875,5325,3000,4520$ & 17668.2 & 0.7328 \\
9 & $3455,3840,5860,8055,5875,5325,3000,4520,4030$ & 18672.3 & 0.7745 \\
10 & $3455,3840,5860,8055,5875,5325,3000,4520,4030,6005$ & 19310.6 & 0.8010 \\
11 & $3455,3840,5860,8055,5875,5325,3000,4520,4030,6005,5175$ & 19901.9 & 0.8255 \\
12 & $3455,3840,5860,8055,5875,5325,3000,4520,4030,6005,5175,5085$ & 20390.3 & 0.8457 \\
13 & $3455,3840,5860,8055,5875,5325,3000,4520,4030,6005,5175,5085,5475$ & 20773.0 & 0.8616 \\
& $3455,3840,5860,8055,5875,5325,3000,4520,4030,6005,5175,5085,5475$, & & \\
14 & 3210 & 21145.3 & 0.8771 \\
& $3455,3840,5860,8055,5875,5325,3000,4520,4030,6005,5175,5085,5475$, & & \\
15 & 3210,5845 & 21516.3 & 0.8924 \\
\hline
\end{tabular}


Table 19: Summary of Results Using the DCI Method and Demand Pattern 4.0 (Total DCI $=11582.7$ )

\begin{tabular}{|c|c|c|c|}
\hline $\begin{array}{c}\text { Number } \\
\text { of MS }\end{array}$ & Optimal Locations of MS for Demand Pattern 4.0 & $\begin{array}{l}\text { Total } \\
\text { DCI }\end{array}$ & $\begin{array}{c}\text { Coverage } \\
\text { Ratio }\end{array}$ \\
\hline 1 & 3455 & 2222.2 & 0.1919 \\
\hline 2 & 3455,5860 & 3715.8 & 0.3208 \\
\hline 3 & $3455,5860,8055$ & 5149.4 & 0.4446 \\
\hline 4 & $3455,5860,8055,5875$ & 6381.4 & 0.5509 \\
\hline 5 & $3455,5860,8055,5875,3840$ & 7601.6 & 0.6563 \\
\hline 6 & $3455,5860,8055,5875,3840,3000$ & 8096.9 & 0.6991 \\
\hline 7 & $3455,5860,8055,5875,3840,3000,4520$ & 8567.4 & 0.7397 \\
\hline 8 & $3455,5860,8055,5875,3840,3000,4520,5325$ & 9020.9 & 0.7788 \\
\hline 9 & $3455,5860,8055,5875,3840,3000,4520,5325,4030$ & 9467.7 & 0.8174 \\
\hline 10 & $3455,5860,8055,5875,3840,3000,4520,5325,4030,5175$ & 9736.7 & 0.8406 \\
\hline 11 & $3455,5860,8055,5875,3840,3000,4520,5325,4030,5175,6005$ & 9961.9 & 0.8601 \\
\hline 12 & $3455,5860,8055,5875,3840,3000,4520,5325,4030,5175,6005,5085$ & 10151.1 & 0.8764 \\
\hline 13 & $3455,5860,8055,5875,3840,3000,4520,5325,4030,5175,6005,5085,5845$ & 10314.6 & 0.8905 \\
\hline 14 & $\begin{array}{c}3455,5860,8055,5875,3840,3000,4520,5325,4030,5175,6005,5085,5845, \\
3210\end{array}$ & 10453.3 & 0.9025 \\
\hline 15 & $\begin{array}{c}\begin{array}{c}3455,5860,8055,5875,3840,3000,4520,5325,4030,5175,6005,5085,5845 \\
3210,5475\end{array}\end{array}$ & 10587.2 & 0.9141 \\
\hline
\end{tabular}

Table 20: Summary of Results Using the DCI Method and Demand Pattern 5.0 (Total DCI = 10591.4)

\begin{tabular}{|c|c|c|c|}
\hline $\begin{array}{l}\text { Number } \\
\text { of MS }\end{array}$ & Optimal Locations of MS for Demand Pattern 5.0 & $\begin{array}{l}\text { Total } \\
\text { DCI }\end{array}$ & $\begin{array}{l}\text { Coverage } \\
\text { Ratio }\end{array}$ \\
\hline 1 & 3455 & 1652.7 & 0.1560 \\
\hline 2 & 3455,3840 & 2897.5 & 0.2736 \\
\hline 3 & $3455,3840,5860$ & 4128.4 & 0.3898 \\
\hline 4 & $3455,3840,5860,8055$ & 5303.2 & 0.5007 \\
\hline 5 & $3455,3840,5860,8055,5875$ & 6398.4 & 0.6041 \\
\hline 6 & $3455,3840,5860,8055,5875,5325$ & 6907.2 & 0.6522 \\
\hline 7 & $3455,3840,5860,8055,5875,5325,3000$ & 7409.6 & 0.6996 \\
\hline 8 & $3455,3840,5860,8055,5875,5325,3000,4520$ & 7866.2 & 0.7427 \\
\hline 9 & $3455,3840,5860,8055,5875,5325,3000,4520,4030$ & 8311.1 & 0.7847 \\
\hline 10 & $3455,3840,5860,8055,5875,5325,3000,4520,4030,6005$ & 8575.5 & 0.8097 \\
\hline 11 & $3455,3840,5860,8055,5875,5325,3000,4520,4030,6005,5175$ & 8827.4 & 0.8335 \\
\hline 12 & $3455,3840,5860,8055,5875,5325,3000,4520,4030,6005,5175,5085$ & 9035.6 & 0.8531 \\
\hline 13 & $\begin{array}{l}3455,3840,5860,8055,5875,5325,3000,4520,4030,6005,5175,5085,5845 \\
3455,3840,5860,8055,5875,5325,3000,4520,4030,6005,5175,5085,5845\end{array}$ & 9206.4 & 0.8692 \\
\hline 14 & 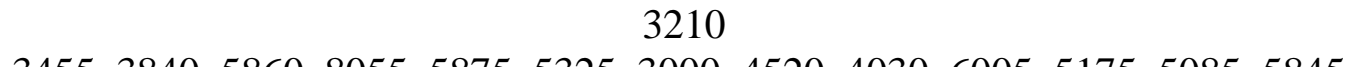 & 9363.0 & 0.8840 \\
\hline 15 & $\begin{array}{c}3455,3840,5860,8055,5875,5325,3000,4520,4030,6005,5175,5085,5845 \\
3210,5475\end{array}$ & 9516.2 & 0.8985 \\
\hline
\end{tabular}


Table 21: Summary of Results Using the DCI Method and Demand Pattern 6.0 (Total DCI $=9114.5$ )

\begin{tabular}{|c|c|c|c|}
\hline $\begin{array}{l}\text { Number } \\
\text { of MS }\end{array}$ & Optimal Locations of MS for Demand Pattern 6.0 & $\begin{array}{l}\text { Total } \\
\text { DCI }\end{array}$ & $\begin{array}{l}\text { Coverage } \\
\text { Ratio }\end{array}$ \\
\hline 1 & 3455 & 1336.8 & 0.1467 \\
\hline 2 & 3455,5860 & 2421.0 & 0.2656 \\
\hline 3 & $3455,5860,3840$ & 3489.0 & 0.3828 \\
\hline 4 & $3455,5860,3840,8055$ & 4430.5 & 0.4861 \\
\hline 5 & $3455,5860,3840,8055,5875$ & 5247.1 & 0.5757 \\
\hline 6 & $3455,5860,3840,8055,5875,5325$ & 5723.3 & 0.6279 \\
\hline 7 & $3455,5860,3840,8055,5875,5325,3000$ & 6175.2 & 0.6775 \\
\hline 8 & $3455,5860,3840,8055,5875,5325,3000,4520$ & 6597.2 & 0.7238 \\
\hline 9 & $3455,5860,3840,8055,5875,5325,3000,4520,4030$ & 6971.4 & 0.7649 \\
\hline 10 & $3455,5860,3840,8055,5875,5325,3000,4520,4030,6005$ & 7224.4 & 0.7926 \\
\hline 11 & $3455,5860,3840,8055,5875,5325,3000,4520,4030,6005,5175$ & 7462.1 & 0.8187 \\
\hline 12 & $3455,5860,3840,8055,5875,5325,3000,4520,4030,6005,5175,5085$ & 7654.8 & 0.8399 \\
\hline 13 & $3455,5860,3840,8055,5875,5325,3000,4520,4030,6005,5175,5085,5475$ & 7806.8 & 0.8565 \\
\hline 14 & $3455,5860,3840,8055,5875,5325,3000,4520,4030,6005,5175,5085,5475$, & 7954.5 & 0.8727 \\
\hline 15 & $\begin{array}{c}3455,5860,3840,8055,5875,5325,3000,4520,4030,6005,5175,5085,5475 \\
5845,3210\end{array}$ & 8102.1 & 0.8889 \\
\hline
\end{tabular}

Table 22: Summary of Results Using the DCI Method and Demand Pattern 7.0 (Total DCI = 9654.5)

\begin{tabular}{|c|c|c|c|}
\hline $\begin{array}{c}\text { Number } \\
\text { of MS }\end{array}$ & Optimal Locations of MS for Demand Pattern 7.0 & $\begin{array}{c}\text { Total } \\
\text { DCI }\end{array}$ & $\begin{array}{c}\text { Coverage } \\
\text { Ratio }\end{array}$ \\
\hline 1 & 3455 & 1509.3 & 0.1563 \\
2 & 3455,3840 & 2660.9 & 0.2756 \\
3 & $3455,3840,5860$ & 3780.9 & 0.3916 \\
4 & $3455,3840,5860,8055$ & 4820.9 & 0.4993 \\
5 & $3455,3840,5860,8055,5875$ & 5689.4 & 0.5893 \\
6 & $3455,3840,5860,8055,5875,5325$ & 6171.8 & 0.6393 \\
7 & $3455,3840,5860,8055,5875,5325,3000$ & 6631.2 & 0.6869 \\
8 & $3455,3840,5860,8055,5875,5325,3000,4520,4030$ & 7065.3 & 0.7318 \\
9 & $3455,3840,5860,8055,5875,5325,3000,4520,4030,6005$ & 7462.8 & 0.7730 \\
10 & $3455,3840,5860,8055,5875,5325,3000,4520,4030,6005,5175,5085$ & 7917.5 & 0.7994 \\
11 & $3455,3840,5860,8055,5875,5325,3000,4520,4030,6005,5175,5085,5475$ & 8304.4 & 0.8602 \\
12 & $3455,3840,5860,8055,5875,5325,3000,4520,4030,6005,5175,5085,5475$, & & 0.8242 \\
13 & 5845 & 8455.9 & 0.8759 \\
14 & $3455,3840,5860,8055,5875,5325,3000,4520,4030,6005,5175,5085,5475$, & & \\
& 5845,3210 & 8605.4 & 0.8913 \\
\hline
\end{tabular}




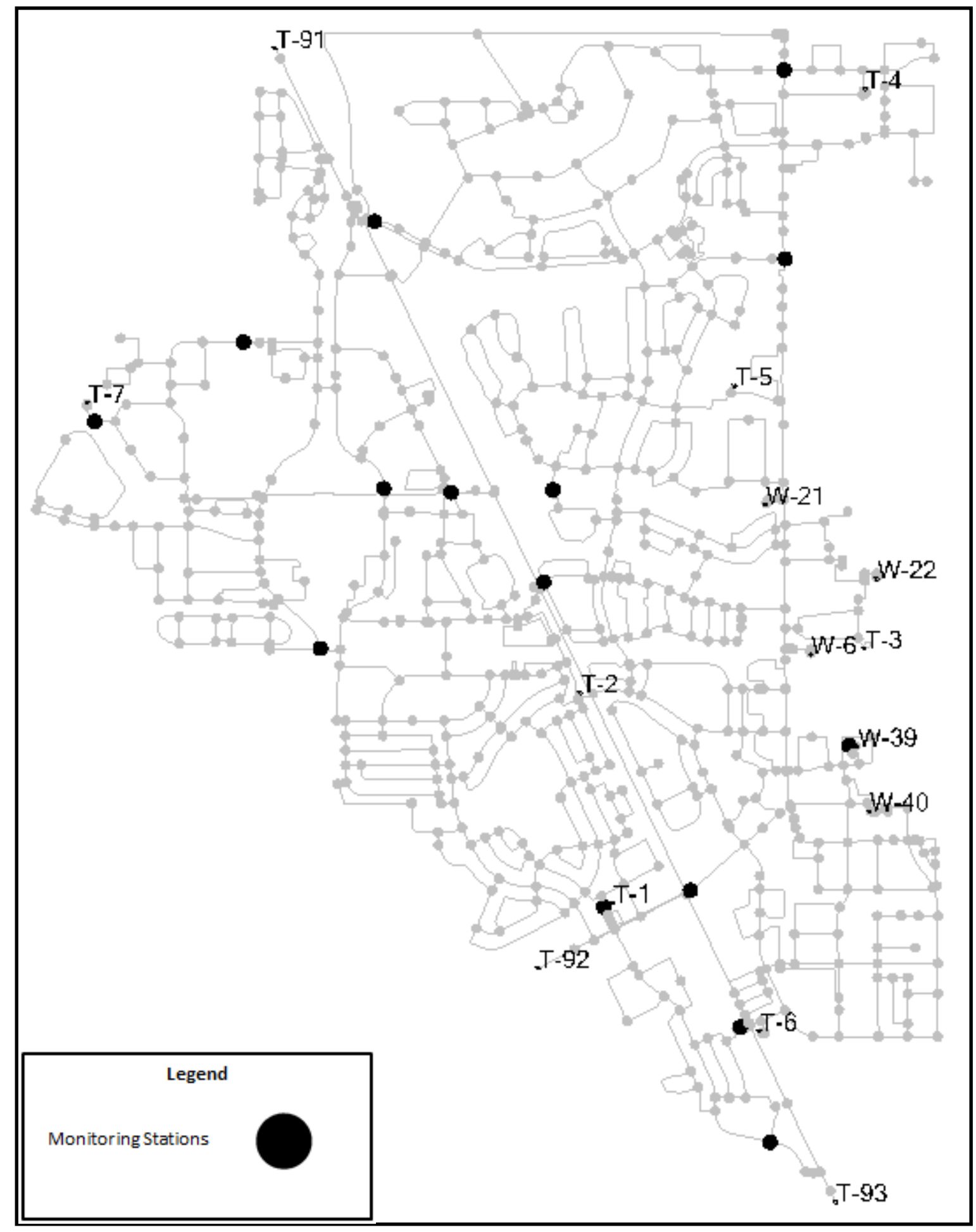

Figure 18: Top 15 Monitoring Stations 


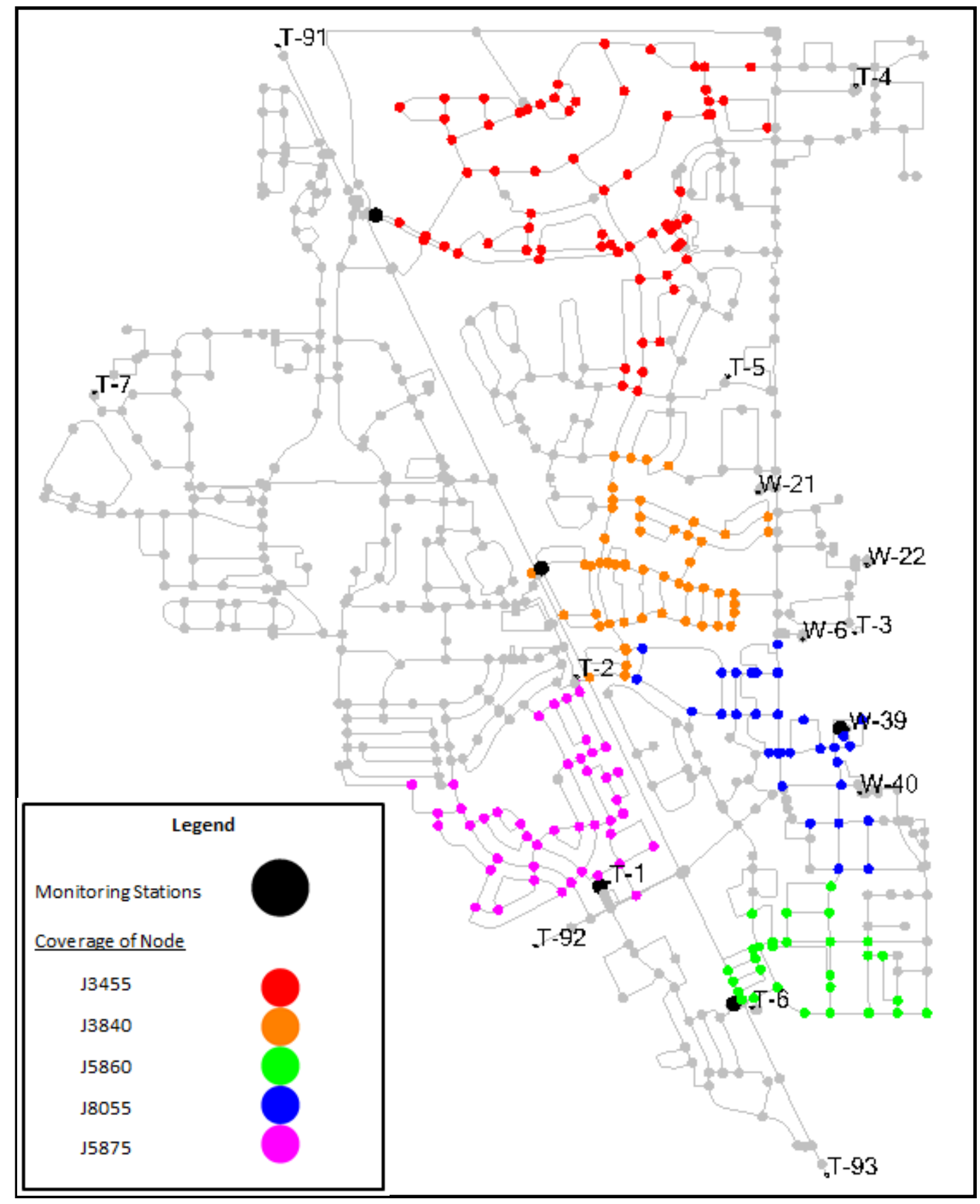

Figure 19: Monitoring Station 1-5 with Corresponding Coverages 


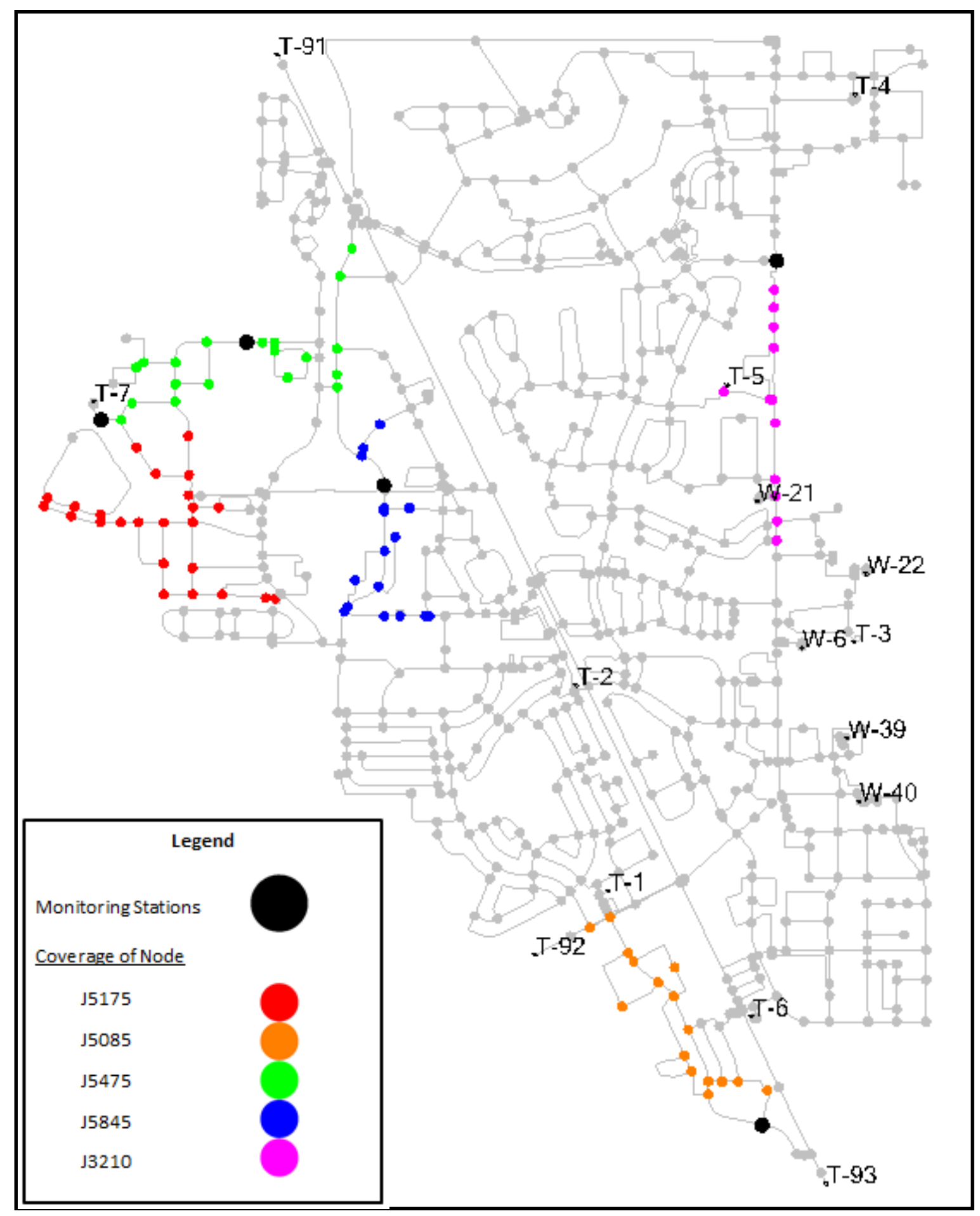

Figure 20: Monitoring Stations 6-10 with Corresponding Coverages 


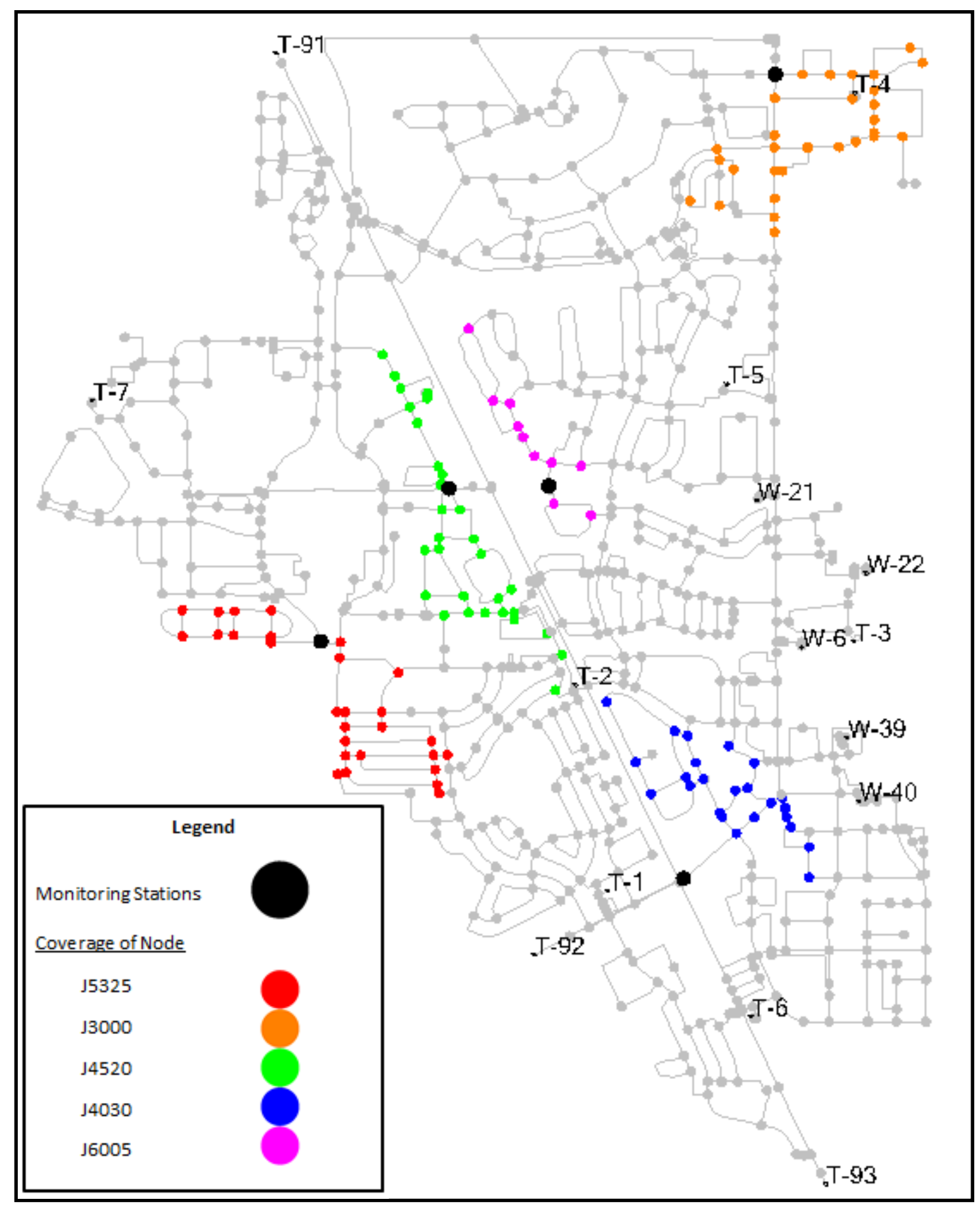

Figure 21: Monitoring Stations 11-15 with Corresponding Coverages 


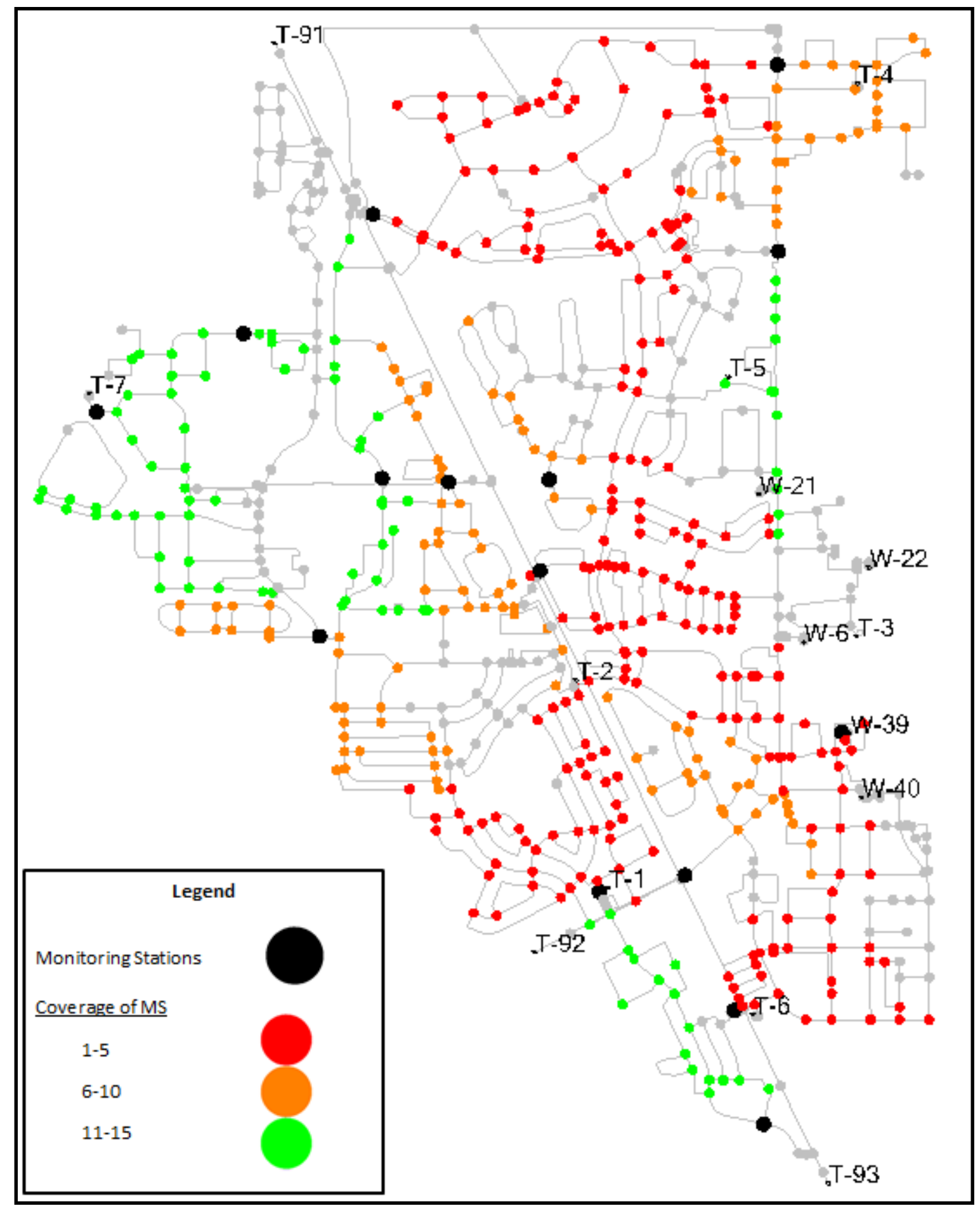

Figure 22: Top 15 Monitoring Stations with Corresponding Coverages 


\subsubsection{Scenario 8: Pattern 2.0 with $\mathrm{Cc}=25 \%, 50 \%$, and $75 \%$}

The monitoring stations will cover more nodes with a lower coverage criterion.

Table 23 demonstrates how the coverage decreases as the coverage criterion increase. A coverage criterion of $50 \%$ should be used because it makes sense that if half of the water in a node downstream came from an upstream node, than the downstream node is representative of the upstream node. Another aspect that the coverage criterion affects is the coverage ratio. The coverage ratio will increase with the decreasing coverage criterion. This is because more nodes are being covered under a single monitoring station. Figure 23-25 show the varying coverages of the 5 monitoring stations.

Table 23: Results of Changing Coverage Criterion

\begin{tabular}{|c|c|c|c|}
\hline \multirow{2}{*}{ Node } & \multicolumn{3}{|c|}{ No. of Nodes Covered } \\
\cline { 2 - 4 } & $\mathbf{C C}=\mathbf{2 5 \%}$ & $\mathbf{C C}=\mathbf{5 0 \%}$ & $\mathbf{C C}=\mathbf{7 5 \%}$ \\
\hline 3455 & 75 & 68 & 17 \\
3840 & 57 & 54 & 47 \\
5860 & 31 & 30 & 20 \\
8055 & 47 & 33 & 22 \\
5875 & 48 & 46 & 32 \\
\hline
\end{tabular}




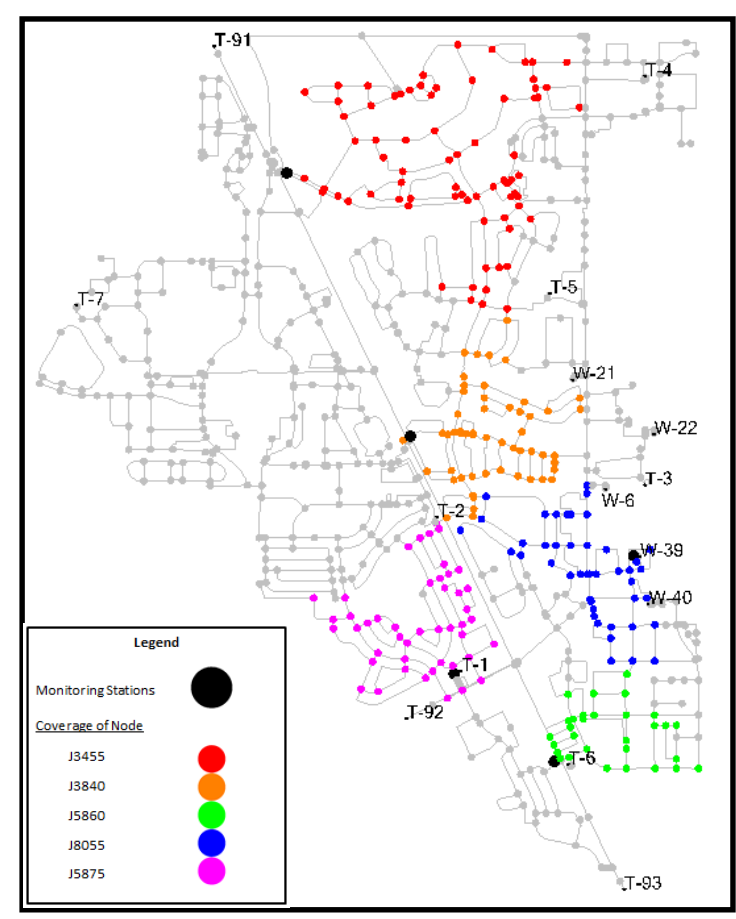

Figure 23: MSs 1-5 with $\mathrm{Cc}=25 \%$

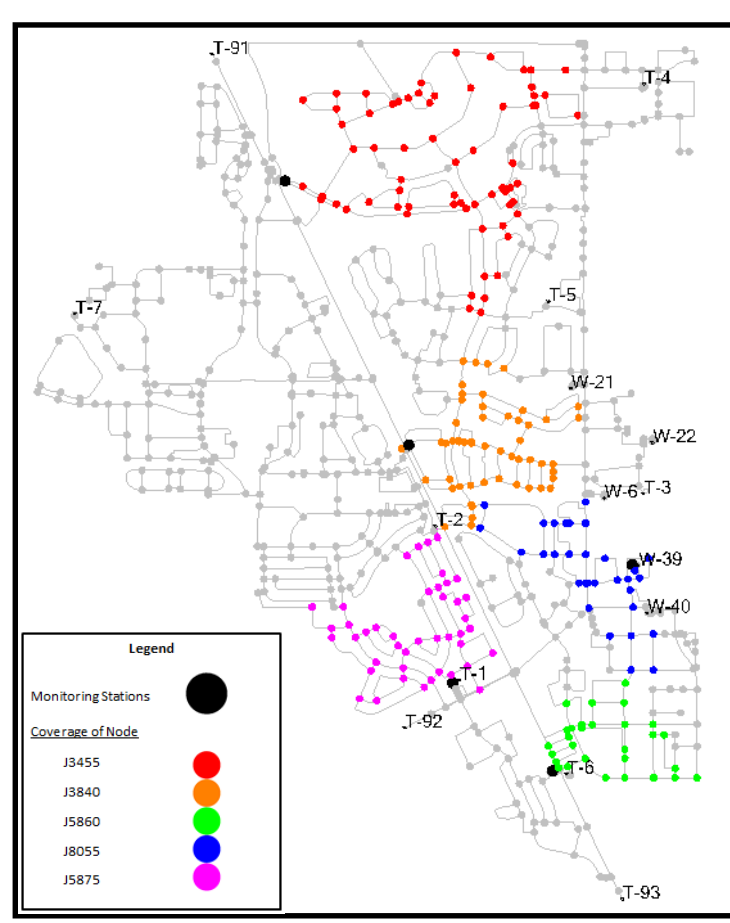

Figure 24: MSs 1-5 with $\mathrm{Cc}=50 \%$

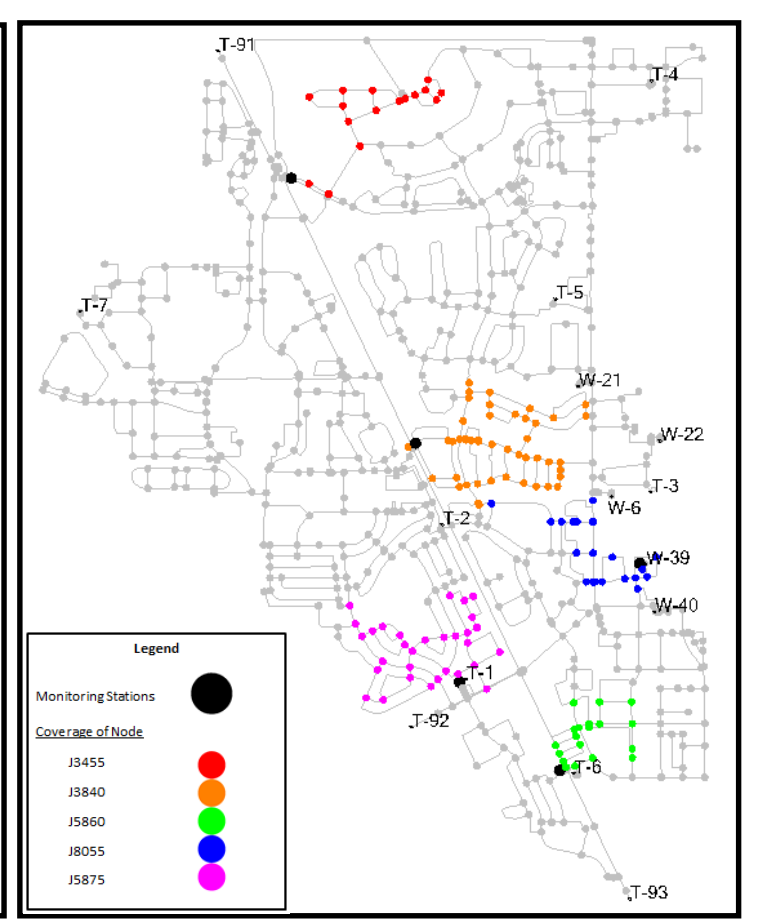

Figure 25: MSs 1-5 with Cc=75\% 


\subsubsection{Scenario 9: 95\% Coverage Ratio}

In reply to a city's request for added protection due to increased funds, 22

monitoring stations would be needed to achieve a coverage ratio of $95.3 \%$ as seen in table 24. Demand pattern 2.0 was used in this analysis but the different temporal distributions will not vary significantly as demonstrated by the results of scenario $1-7$. These additional monitoring stations represent enhanced protection a city can employ in the WDS if funds are available. 549 of the 619 nodes are covered, or $88.7 \%$, with all but 17 having a DCI of less than 5. Figure 26 and 27 show the additional coverage of monitoring stations 16-22. Figure 28 shows all 22 monitoring stations for this city with corresponding coverages.

Table 24: Results for Additional MS's in Order to Achieve a 95\% Coverage Ratio (Total $\mathrm{DCI}=24867.8$ )

\begin{tabular}{|c|c|c|c|}
\hline $\begin{array}{c}\text { Number } \\
\text { of MS }\end{array}$ & Additional Optimal Locations of MS for Demand Pattern 2.0 & $\begin{array}{c}\text { Total } \\
\text { DCI }\end{array}$ & $\begin{array}{c}\text { Coverage } \\
\text { Ratio }\end{array}$ \\
\hline 16 & 8005 & 22276.7 & 0.8958 \\
17 & 8005,8070 & 22567.4 & 0.9075 \\
18 & $8005,8070,3662$ & 22834.7 & 0.9182 \\
19 & $8005,8070,3662,4580$ & 23097.6 & 0.9288 \\
20 & $8005,8070,3662,4580,5850$ & 23326.2 & 0.9380 \\
21 & $8005,8070,3662,4580,5850,5840$ & 23532.6 & 0.9463 \\
22 & $8005,8070,3662,4580,5850,5840,6015$ & 23697.1 & 0.9529 \\
\hline
\end{tabular}




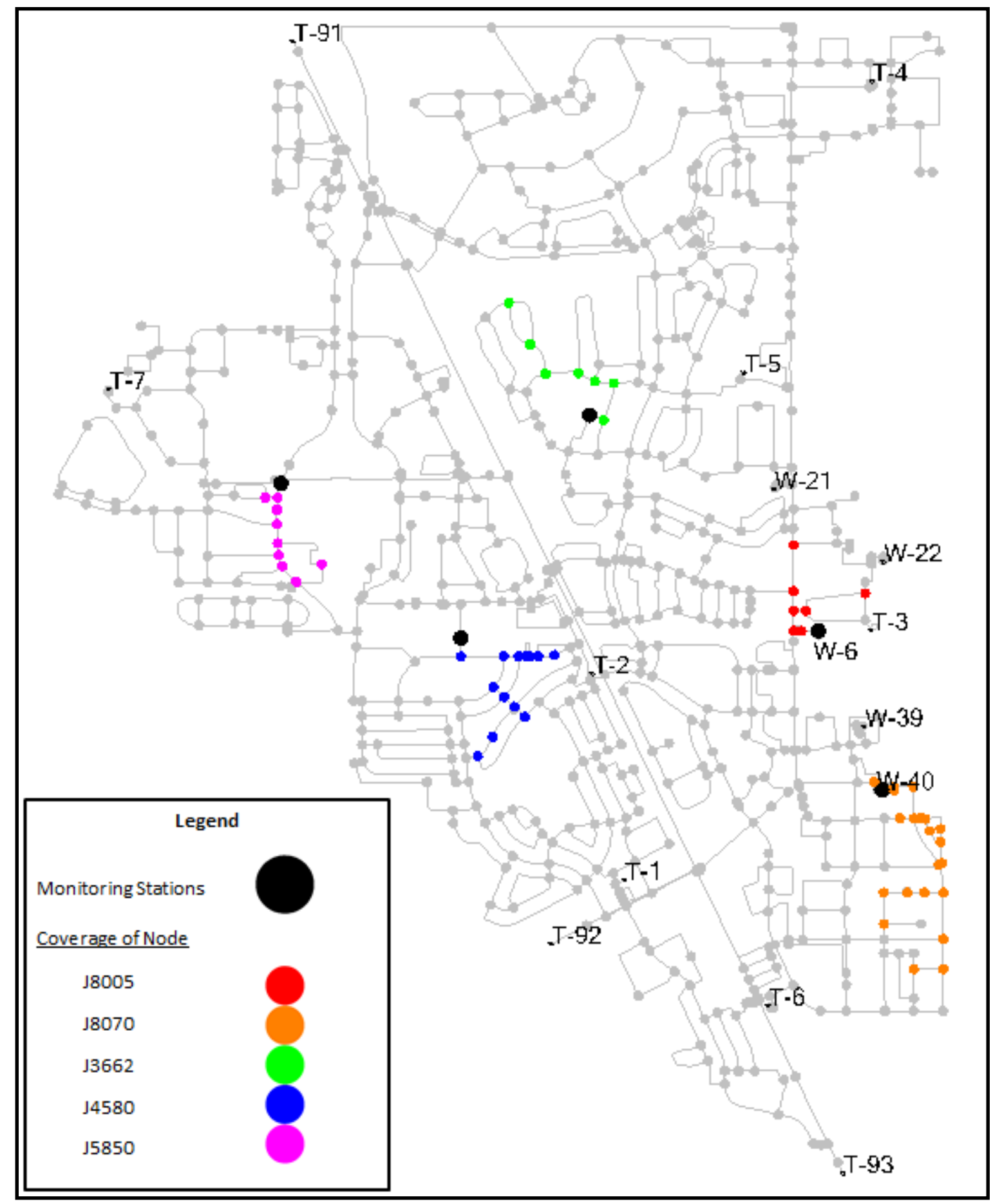

Figure 26: MS 16-20 with Corresponding Coverages 


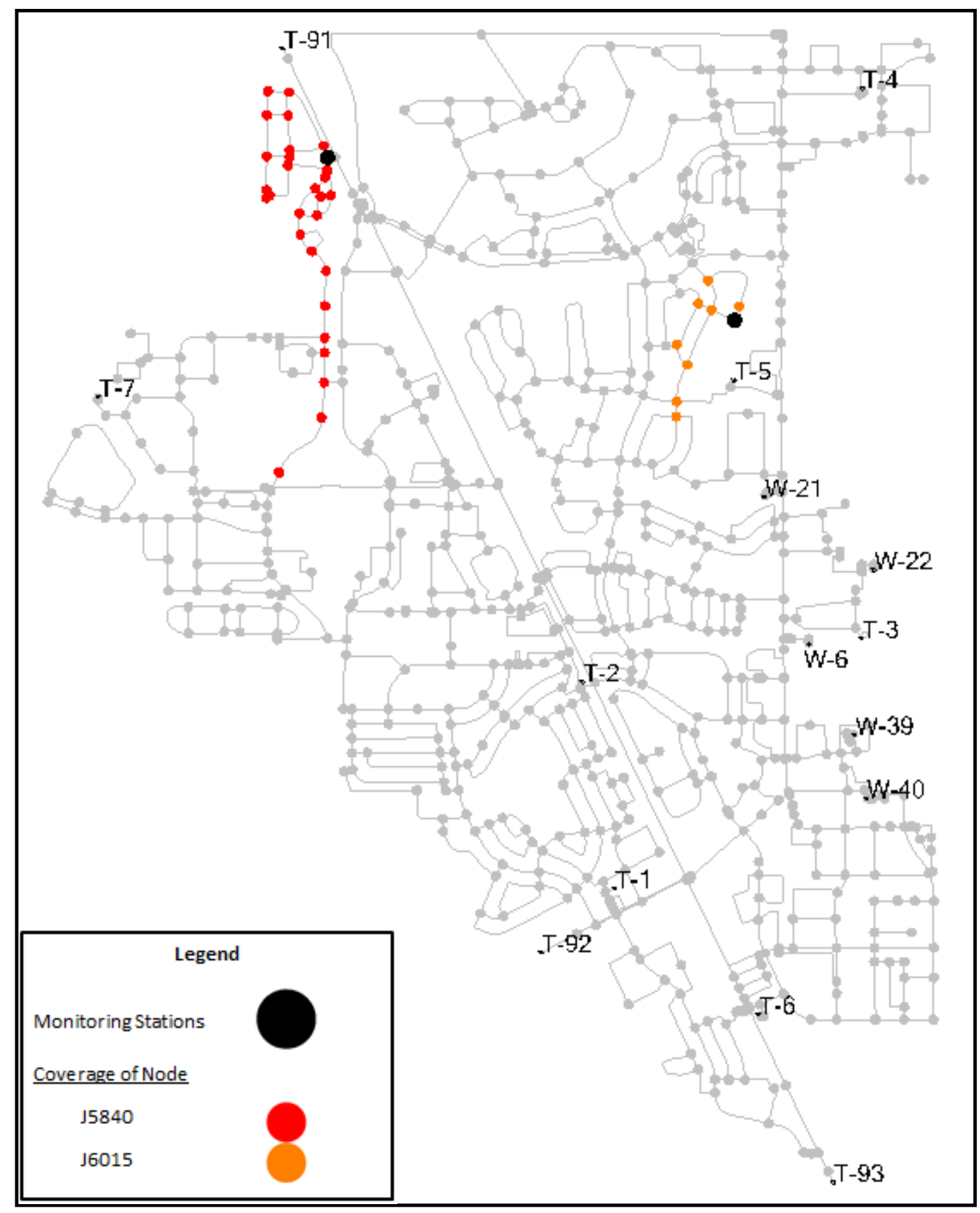

Figure 27: MS 21-22 with Corresponding Coverages 


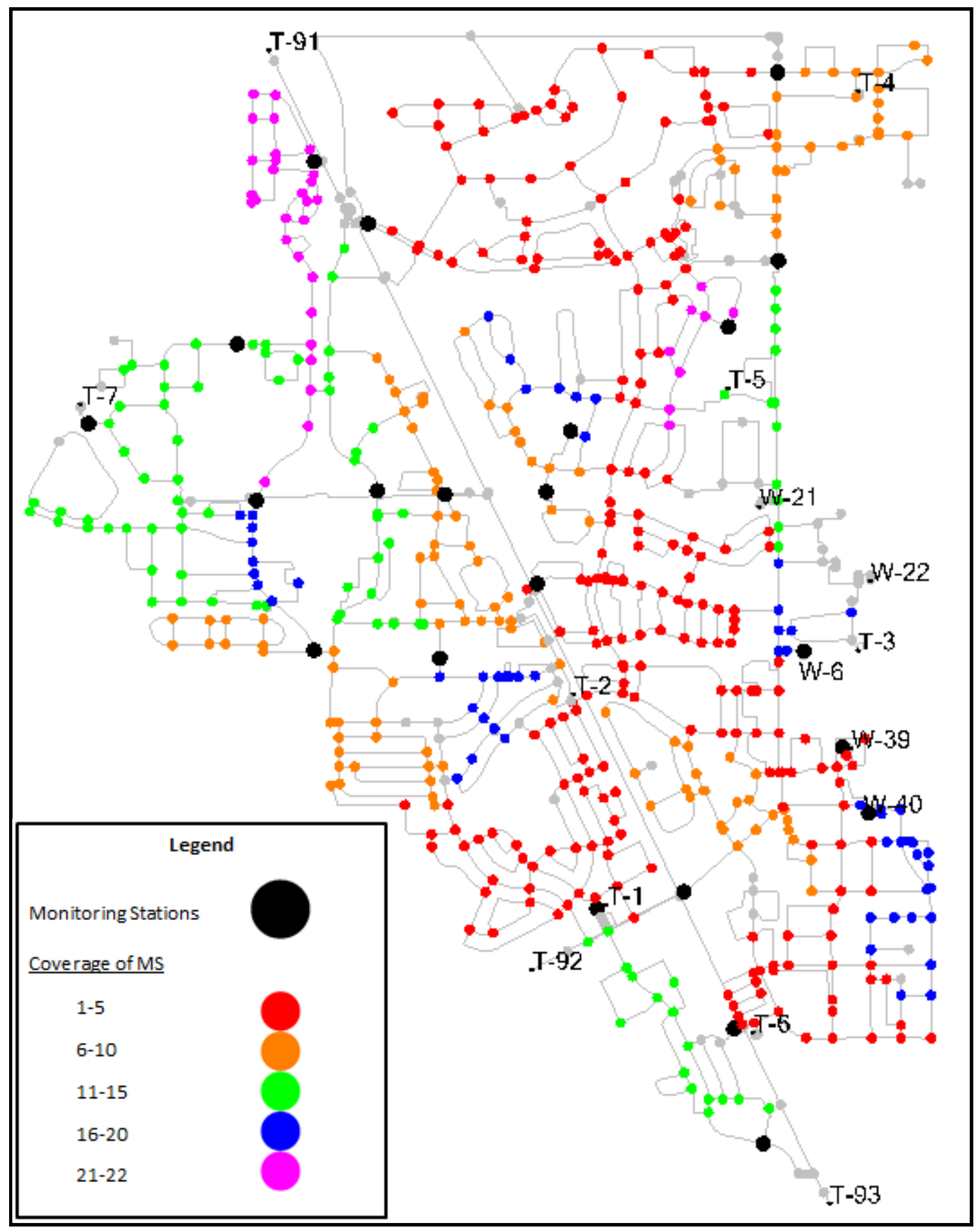

Figure 28: Top 22 Monitoring Stations with Corresponding Coverages 


\subsubsection{Scenario 10: Demand Coverage vs Demand Coverage Index}

The DC results are similar to the DCI results but there are several of the lower ranked monitoring stations that differ. Another big difference is the lower coverage ratio. Table 25 and 26 shows the results of the DC method while table 16 and 17 shows the DCI method. The average for the DC method is about $84 \%$ while for the DCI method it is about $90 \%$. The DCI has a better coverage ratio and can be applied to a changing temporal distribution, thus the DCI method can be used for more scenarios with a higher level of accuracy.

Table 25: Results Using the Demand Coverage Method for Max Daily Demand Pattern

\begin{tabular}{|c|c|c|c|}
\hline \multicolumn{4}{|c|}{ Max Daily Demand Pattern } \\
\hline $\begin{array}{l}\text { Number } \\
\text { of MS }\end{array}$ & Optimal Locations of MS for Max Daily Demand Pattern & $\begin{array}{l}\text { Total } \\
\text { TDC }\end{array}$ & $\begin{array}{l}\text { Coverage } \\
\text { Ratio }\end{array}$ \\
\hline 1 & 3455 & 224160 & 0.1334 \\
\hline 2 & 3455,3840 & 405739 & 0.2415 \\
\hline 3 & $3455,3840,8055$ & 555266 & 0.3304 \\
\hline 4 & $3455,3840,8055,5860$ & 694513 & 0.4133 \\
\hline 5 & $3455,3840,8055,5860,5875$ & 812113 & 0.4833 \\
\hline 6 & $3455,3840,8055,5860,5875,3000$ & 909536 & 0.5413 \\
\hline 7 & $3455,3840,8055,5860,5875,3000,4520$ & 1004870 & 0.5980 \\
\hline 8 & $3455,3840,8055,5860,5875,3000,4520,4030$ & 1078139 & 0.6416 \\
\hline 9 & $3455,3840,8055,5860,5875,3000,4520,4030,5175$ & 1151368 & 0.6852 \\
\hline 10 & $3455,3840,8055,5860,5875,3000,4520,4030,5175,5325$ & 1220845 & 0.7265 \\
\hline 11 & $3455,3840,8055,5860,5875,3000,4520,4030,5175,5325,5840$ & 1266839 & 0.7539 \\
\hline 12 & $3455,3840,8055,5860,5875,3000,4520,4030,5175,5325,5840,5845$ & 1306295 & 0.7774 \\
\hline 13 & $\begin{array}{l}3455,3840,8055,5860,5875,3000,4520,4030,5175,5325,5840,5845,8070 \\
3455,3840,8055,5860,5875,3000,4520,4030,5175,5325,5840,5845,8070,\end{array}$ & 1343785 & 0.7997 \\
\hline 14 & $\begin{array}{c}5085 \\
3455,3840,8055,5860,5875,3000,4520,4030,5175,5325,5840,5845,8070\end{array}$ & 1380138 & 0.8213 \\
\hline 15 & 5085,6005 & 1415314 & 0.8423 \\
\hline
\end{tabular}


Table 26: Results Using the Demand Coverage Method for Demand Pattern 2.0

\begin{tabular}{|c|c|c|c|}
\hline \multicolumn{4}{|c|}{ Pattern 2.0 Demand Pattern } \\
\hline $\begin{array}{c}\text { Number } \\
\text { of MS }\end{array}$ & Optimal Locations of MS for Pattern 2.0 Demand Pattern & $\begin{array}{c}\text { Total } \\
\text { TDC }\end{array}$ & $\begin{array}{c}\text { Coverage } \\
\text { Ratio }\end{array}$ \\
\hline 1 & 3455 & 234282 & 0.1350 \\
2 & 3455,3840 & 420047 & 0.2420 \\
3 & $3455,3840,8055$ & 575226 & 0.3315 \\
4 & $3455,3840,8055,5860$ & 718892 & 0.4142 \\
5 & $3455,3840,8055,5860,5875$ & 840810 & 0.4845 \\
6 & $3455,3840,8055,5860,5875,3000$ & 944970 & 0.5445 \\
7 & $3455,3840,8055,5860,5875,3000,4520$ & 1042487 & 0.6007 \\
8 & $3455,3840,8055,5860,5875,3000,4520,5175$ & 1116860 & 0.6436 \\
9 & $3455,3840,8055,5860,5875,3000,4520,5175,5325$ & 1188147 & 0.6846 \\
10 & $3455,3840,8055,5860,5875,3000,4520,5175,5325,4030$ & 1253629 & 0.7224 \\
11 & $3455,3840,8055,5860,5875,3000,4520,5175,5325,4030,5840$ & 1303579 & 0.7511 \\
12 & $3455,3840,8055,5860,5875,3000,4520,5175,5325,4030,5840,5845$ & 1344083 & 0.7745 \\
13 & $3455,3840,8055,5860,5875,3000,4520,5175,5325,4030,5840,5845,8070$ & 1383591 & 0.7972 \\
& $3455,3840,8055,5860,5875,3000,4520,5175,5325,4030,5840,5845,8070$, & & \\
14 & 3210 & 1420673 & 0.8186 \\
& $3455,3840,8055,5860,5875,3000,4520,5175,5325,4030,5840,5845,8070$, & & \\
15 & 3210,5085 & 1457661 & 0.8399 \\
\hline
\end{tabular}




\subsection{Comparison of Results}

Laurence (Johnson, 2012) performed an analysis on this same model to determine optimal locations for monitoring stations using a heuristic method. His method involved counting how many times a node detected contamination when the tanks were contaminated during their particular booster schedule (Table 5). This was a simple method and his results are seen in figure 29. The results show 3 areas of significance where monitoring stations should be placed. He simulated tanks being contaminated because that is the most likely delivery point if intentional contamination were to occur. It was also assumed that there would be fewer monitoring stations than the number of tanks which is 7 . This is a major difference between our results because this study suggested at least 15 monitoring stations.

Results of this study vary significantly from Laurence because his method accounted for contamination events of the tanks only which is the most likely event but all nodes should be assumed likely candidates for contamination. This should be done because people looking to contaminate a WDS will not always pick the most likely location but instead will be intelligent and look for weak spots in the system. This study's method assumes that any node can be contaminated so monitoring stations are strategically scattered around the WDS while his are clustered in three areas of

significance. These three areas are covered by three monitoring stations in this study but this still leaves a huge number of nodes not being monitoring.

Laurence also did not analyze multiple demand patterns which can affect the locations of monitoring stations. Using multiple demand patterns is important because 
cities may have different demand patterns depending on location, usage, and seasons which will affect where monitoring stations should be located.

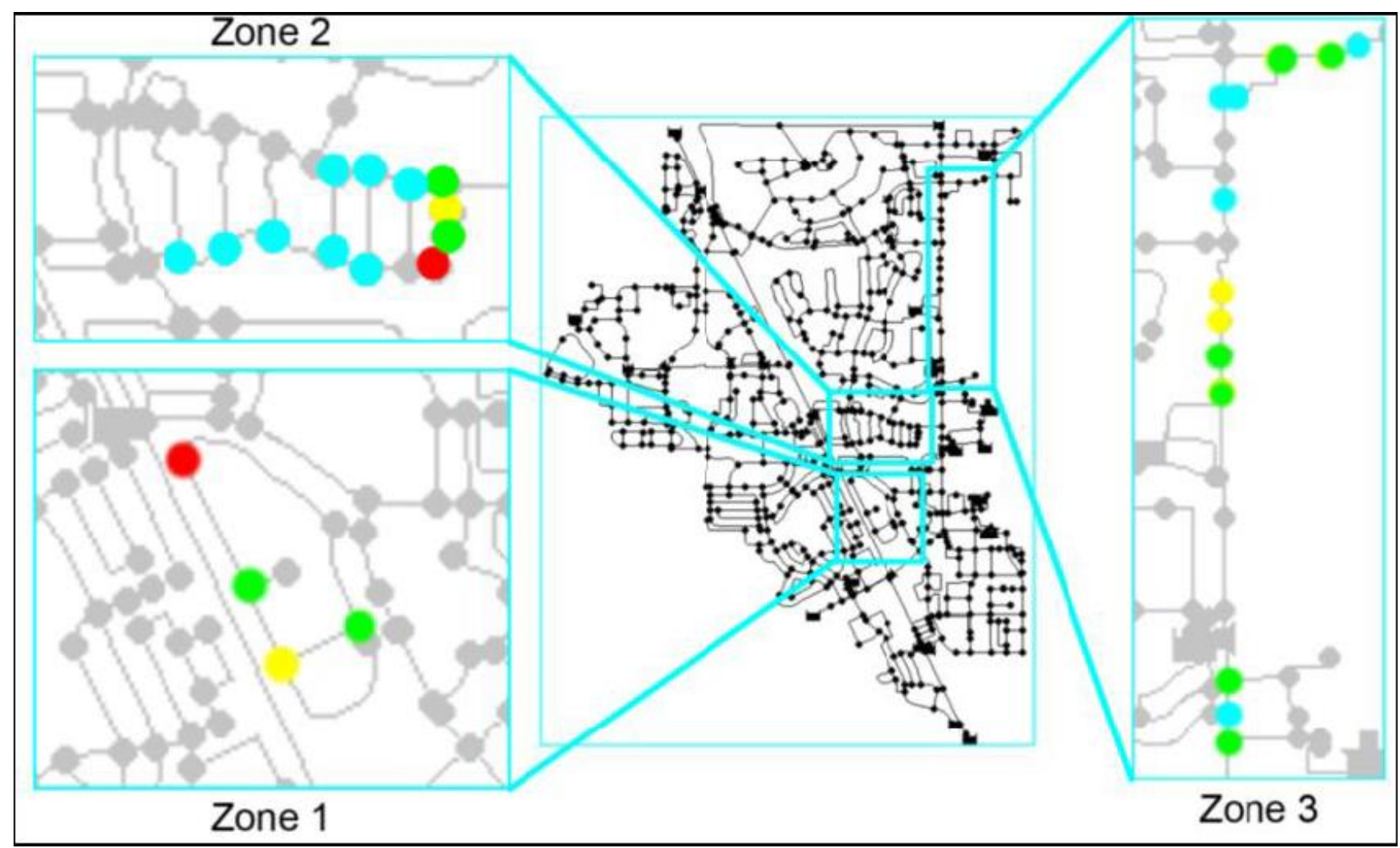

Figure 29: Areas of Significance Determined by Laurence (Johnson, 2012) 


\subsection{Weaknesses of the DCI Method}

The DCI method is a great way to determine the optimal location of monitoring stations but it does have some significant weaknesses. A flaw in the method is that at PRV-118, PRV-119, and PRV-162 there should be monitoring stations to monitor water entering the WDS from the main transmission line. The entire WDS can be seen in figure 30 with the location of the PRV's and top 15 monitoring stations being indicated. The flaw will be examined more closely by looking at PRV-162 in figure 31 . This figure shows that water from the main line enters the WDS at PRV-160, PRV-161, and PRV162 but since there is a monitoring station near PRV-160 that covers the nodes downstream of PRV-162, the DCI method does not indicate that there should be a monitoring station there. This flaw is relatively easy to fix by including monitoring stations near PRV-162. Other locations where this flaw is repeated is at PRV-118 and PRV-119 which are also connected to the main transmission line.

Another flaw is that the DCI method does not take into consideration the water from the tanks being used by the distribution systems. The method only accounts for water being used from the main line. These tanks store water that will ultimately be used by consumers but this water can be contaminated and spread throughout the system. Therefore, there should be a monitoring station near every tank. Tank 2,3 , and 5 are the only tanks without monitoring stations nearby where this flaw would occur.

These flaws are easy to overcome but it is hard to determine how important these extra monitoring stations are compared to the top 15 monitoring station of the WDS. An additional study should be performed to determine if these stations would be in the top 15 monitoring locations. 


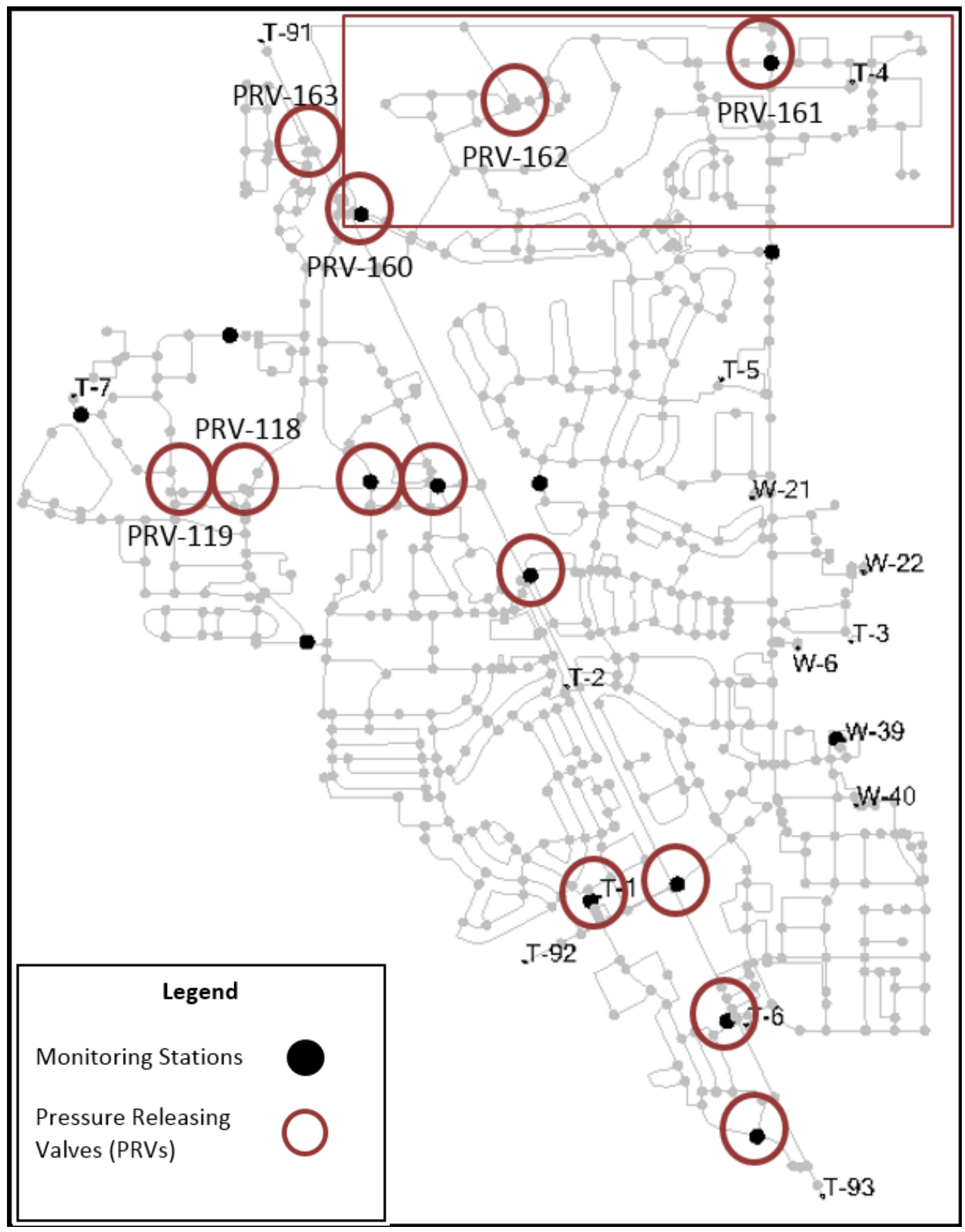

Figure 30: Locations of the Pressure Release Valves (PRVs) Connecting to the Main Transmission Line 


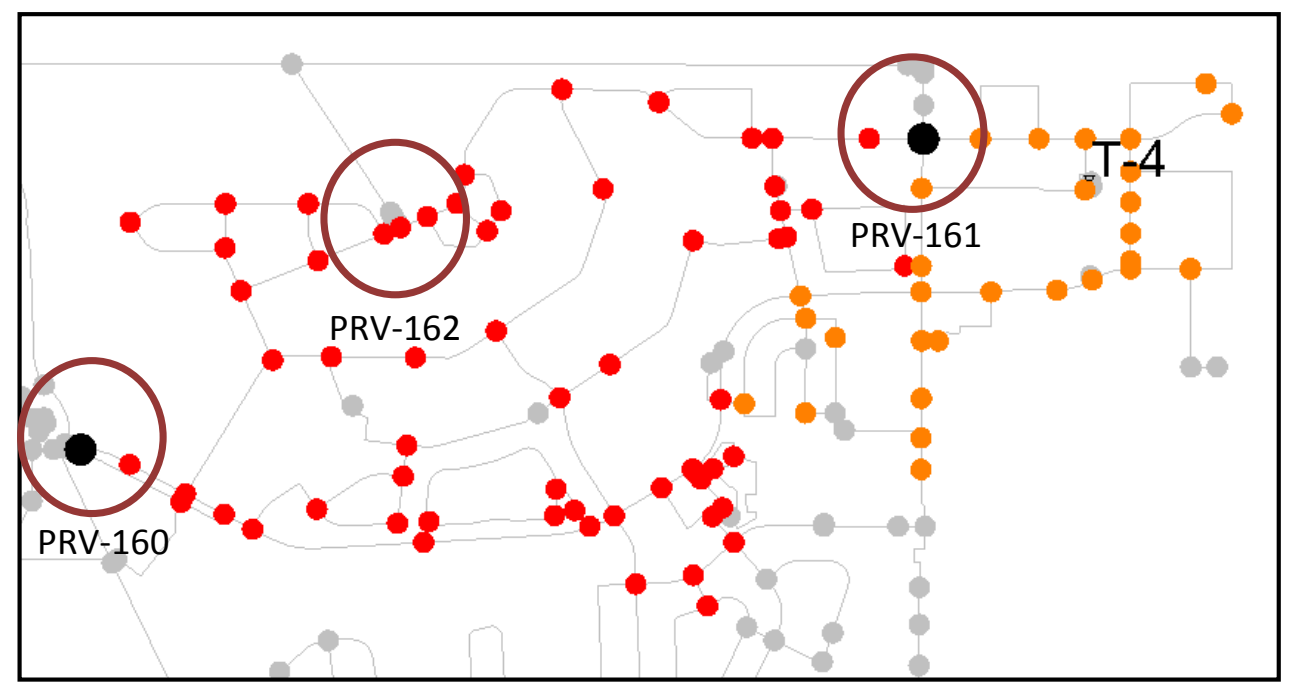

Figure 31: Close Up of PRV-162 


\section{WORKS CITED}

Al-Zahrani M A, Moied K. Locating optimum water quality monitoring stations in water distribution system, in Bridging the Gap: Meeting the World's Water and Environmental Resources Challenges. In Proceedings of the ASCE annual conference on Water Resources Planning and Management. Virginia: Reston, 2001

“An Introduction to Water Quality Monitoring." United States Environmental Protection Agency. EPA, 2 Oct. 2012. Web. 08 Mar. 2014.

<http://water.epa.gov/type/watersheds/monitoring/monintr.cfm>.

"Basic Information about Disinfectants in Drinking Water: Chloramine, Chlorine and Chlorine Dioxide." United States Environmental Protection Agency. EPA, 13 Dec. 2013. Web. 06 Mar. 2014.

<http://water.epa.gov/drink/contaminants/basicinformation/disinfectants.cfm>.

"Bioterrorism Act of 2002." US Food and Drug Administration. U.S. Department of Health and Human Services, 12 June 2002. Web. 10 June 2014.

<http://www.fda.gov/RegulatoryInformation/Legislation/ucm148797.htm.>

"Bright Lights of Madison Avenue Shine on Trenchless Rehab Project." Trenchless Technology. Benjamin Media, Inc, June 2010. Web. May 2014.

$<$ http://trenchlessonline.com/bright-lights-of-madison-avenue-shine-on-trenchlessrehab-project/>.

Brumbelow, Kelly, Jacob Torres, Seth Guikema, Elizabeth Bristow, and Lufthansa Kanta. Virtual Cities For Water Distribution and Infrastructure System Research. World Environmental and Water Resources Congress 2007: Restoring Our Natural Habitat (2007). Print.

Chastain, James R., A heuristic methodology for locating monitoring stations to detect contamination events in potable water distribution systems. (2004). Theses and Dissertations. Paper 988.

"Cryptosporidium." Minnesota Department of Health. Minnesota.gov, Mar. 2014. Web. May 2014.

<http://www.health.state.mn.us/divs/eh/water/factsheet/com/cryptosporidium.html>

Cybersecurity Executive Order: EPA Response on Adoption of the Cybersecurity Framework by the Water Sector (n.d.): n. pag.United States Environmental Protection Agency. USEPA. Web. May 2014.

<http://water.epa.gov/infrastructure/watersecurity/upload/EO_13696_10-b_EPA_response.pdf $>$. 
"Cyber Security 101 for Water Utilities." (n.d.): n. pag. United States Environmental Protection Agency. USEPA, July 2012. Web. Aug. 2014.

<http://water.epa.gov/infrastructure/watersecurity/features/upload/epa817k12004.pd $\mathrm{f}>$.

"Drinking Water D." 2013 Report Card for America's Infrastructure. American Society of Civil Engineers, 2013. Web. Dec. 2014.

$<\mathrm{http} / /$ infrastructurereportcard.org/drinking-water/>.

"Filter Backwash Recycling Rule." United States Environmental Protection Agency. EPA, 11 Sept. 2013. Web. 7 Mar. 2014. <http://water.epa.gov/lawsregs/rulesregs/sdwa/filterbackwash.cfm>.

"Groundwater Under the Direct Influence of Surface Water." Oregon.gov. Oregon Public Health Division, n.d. Web. Apr. 2014.

$<$ http://public.health.oregon.gov/HealthyEnvironments/DrinkingWater/SourceWate r/Pages/gwudi.aspx $>$.

"Hack Attack Causes 'Massive Damage' at Steel Works." BBC News. BBC, 22 Dec. 2014. Web. 28 Jan. 2015. <http://www.bbc.com/news/technology-30575104>.

Haimes, Y. Y., Matalas, N. C., Lambert, J. H., Jackson, B. A., \& Fellows, J. F. (1998). Reducing vulnerability of water supply systems to attack. Journal of Infrastructure Systems, 4(4), 164-177.

Hall, John S., and Jeffrey G. Szabo. Distribution System Water Quality Monitoring: Sensor Technology Evaluation Methodology and Results. USEPA, Oct. 2009. PDF.

"Home." Aqua-Pipe: Water Main Rehabilitation. Aqua-Pipe, n.d. Web. 30 Apr. 2015. $<$ http://www.aqua-pipe.com/>.

"Homeland Security Presidential Directive 5." Department of Homeland Security. 28 Feb. 2003. Web. 10 June 2014. <http://www.dhs.gov/publication/homelandsecurity-presidential-directive-5.>

Hydrant Security: Taking the First Step. Chattanooga: Mueller Co., Apr. 2011. PDF.

Johnson, Lawrence D. "Application of a Heuristic Method to a Water Distribution System for Determining Optimal Water Quality Monitoring Locations." Thesis. San Luis Obispo, 2012. Print.

Kumar A, Kansal M L, Arora G. Identification of monitoring stations in water distribution system. Journal of Environmental Engineering-ASCE, 1997, 123(8): $746-752$ 
Lee B H, Deininger R A. Optimal locations of monitoring stations in water distribution system. Journal of Environmental Engineering-ASCE, 1992, 118(1): 4-16

Liu, Shuming, Wenjun Liu, Jinduan Chen, and Qi Wang. “Optimal Locations of Monitoring Stations in Water Distribution Systems Under Multiple Demand Patterns: A Flaw of Demand Coverage Method and Modification." Frontiers of Environmental Science and Engineering 6.2 (2012): 204-12. Print.

"Long Term 1 Enhanced Surface Water Treatment Rule." United States Environmental Protection Agency. EPA, 8 Dec. 2014. Web. 07 Mar. 2014. <http://water.epa.gov/lawsregs/rulesregs/sdwa/mdbp/lt1/lt1eswtr.cfm>.

Pepitone, Julianne. "Sony Hack: 'Critical' Systems Won't Be Back Online Until February.” NBC News. NBC, 23 Jan. 2015. Web. 28 Jan. 2015. <http://www.nbcnews.com/storyline/sony-hack/sony-hack-critical-systems-wontbe-back-online-until-february-n292126>.

Perlman, Howard. "Runoff (Surfacewater Runoff)." United States Geological Survey. USDI and USGS, Mar. 2014. Web. Apr. 2014. <http://water.usgs.gov/edu/runoff.html>.

"Nature Wildlife." BBC News. BBC, Oct. 2014. Web. 15 June 2014. <http://www.bbc.co.uk/nature/habitats/Brackish>.

Rossman, Lewis A. "EPANET 2 Users Manual." United States Environmental Protection Agency. N.p., Sept. 2000. Web. Feb. 2014. $<$ ftp2.bentley.com/dist/collateral/docs/EPANET/EPANET_Manual.pdf>.

Rossman, L.A. and Grayman, W.M., "Scale-model studies of mixing in drinking water storage tanks," Journal of Environmental Engineering, Vol. 125, No. 8, pp. 755$761,1999$.

"Safe Drinking Water Act (SDWA)." United States Environmental Protection Agency. EPA, 30 July 2014. Web. 21 Mar. 2014. <http://water.epa.gov/lawsregs/rulesregs/sdwa/index.cfm>.

Sanger, David E. “Obama Order Sped Up Wave of Cyberattacks Against Iran.” The New York Times. The New York Times Company, 1 June 2012. Web. 28 Mar. 2014. <http://www.nytimes.com/2012/06/01/world/middleeast/obama-ordered-wave-ofcyberattacks-against-iran.html?pagewanted=all> .

"Summary of the Clean Water Act." United States Environmental Protection Agency. EPA, 12 Nov. 2014. Web. 7 Mar. 2014. <http://www2.epa.gov/lawsregulations/summary-clean-water-act>. 
Surface Water Treatment Rules: What Do They Mean to You? (n.d.): n. pag. United States Environmental Protection Agency. USEPA, Oct. 2011. Web. Mar. 2014. $<$ http://water.epa.gov/lawsregs/rulesregs/sdwa/swtr/upload/SWTRPlainEnglishGuid eFinal.pdf >.

The Cadmus Group, Inc., and USEPA Office of Groundwater and Drinking Water. The Effectiveness of Disinfectant Residuals in the Distribution System, March 2007 (n.d.): n. pag. United States Environmental Protection Agency. May 2014. Web. Aug. 2014. <http://www.epa.gov/ogwdw/disinfection/tcr/pdfs/issuepaper_effectiveness.pdf >.

Todd, David K., and Larry W. Mays. Groundwater Hydrology. $3^{\text {rd }}$ ed. N.p.: Argosy, 2005. Print.

"Water: Basic Information about Regulated Drinking Water Contaminants." United States Environmental Protection Agency. USEPA, Dec. 2013. Web. Apr. 2014. <http://water.epa.gov/drink/contaminants/basicinformation/disinfectants.cfm>.

Tryby M E, Uber J G. Representative water quality sampling in water distribution systems, in Bridging the Gap: Meeting the World's Water and Environmental Resources Challenges. In Proceedings of the ASCE annual conference on Water Resources Planning and Management. Virginia: Reston, 2001

"Water: Drinking Water Contaminants." United States Environmental Protection Agency. USEPA, Oct. 2014. Web. May 2014. <http://water.epa.gov/drink/contaminants/>.

"Water: Drinking Water Strategy." United States Environmental Protection Agency. USEPA, Oct. 2012. Web. May 2014. <http://water.epa.gov/lawsregs/rulesregs/sdwa/dwstrategy/>.

"Water: Interim Enhanced Surface Water Treatment Rule." United States Environmental Protection Agency. USEPA, Mar. 2012. Web. May 2014. <http://water.epa.gov/lawsregs/rulesregs/sdwa/ieswtr/>.

"Water: Key Features of an Active and Effective Security Program." United States Environmental Protection Agency. USEPA, May 2014. Web. Jan. 2014. <http://water.epa.gov/infrastructure/watersecurity/features/index.cfm\#one>.

"Water: Long Term 2 Enhanced Surface Water Treatment Rule (LT2)." United States Environmental Protection Agency. USEPA, Sept. 2013. Web. May 2014. <http://water.epa.gov/lawsregs/rulesregs/sdwa/lt2/index.cfm>.

"Water: Monitoring and Assessment." United States Environmental Protection Agency. USEPA, Mar. 2012. Web. June 2014. <http://water.epa.gov/type/rsl/monitoring/vms50.cfm>. 
"Water: Surface Water Treatment Rule." United States Environmental Protection Agency. USEPA, Mar. 2012. Web. Apr. 2014.

$<$ http://water.epa.gov/lawsregs/rulesregs/sdwa/swtr/>.

"2.2 Designing the Stream Study." United States Environmental Protection Agency. EPA, 6 Mar. 2012. Web. 09 Mar. 2014.

<http://water.epa.gov/type/rsl/monitoring/vms22.cfm>. 
APPENDICES 


\section{APPENDIX A}

The contents of Appendix A include visual representations of the locations of monitoring stations with their corresponding coverages. The coverage criterion is assumed to be $50 \%$ unless otherwise stated. 


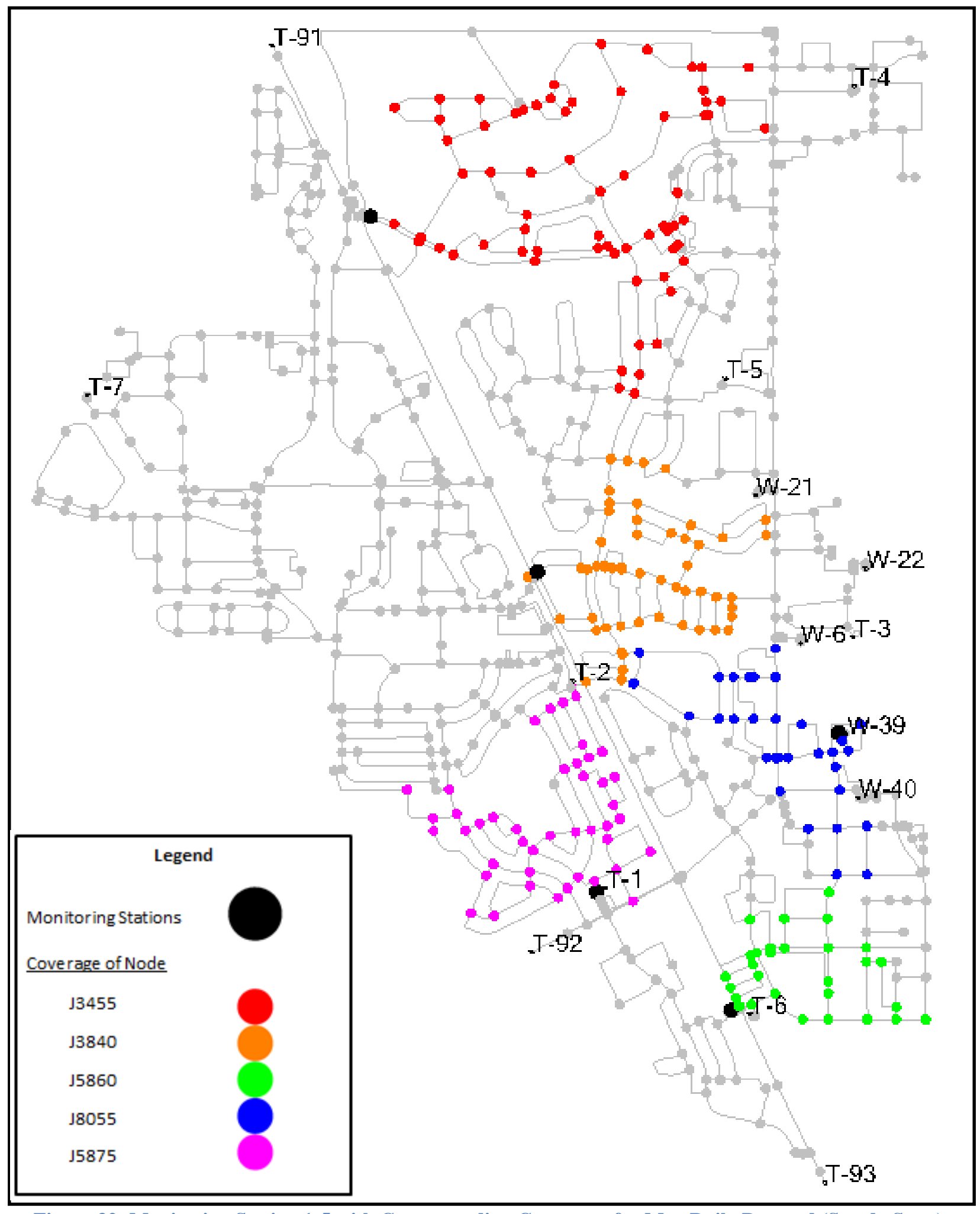

Figure 32: Monitoring Station 1-5 with Corresponding Coverages for Max Daily Demand (Steady State) 


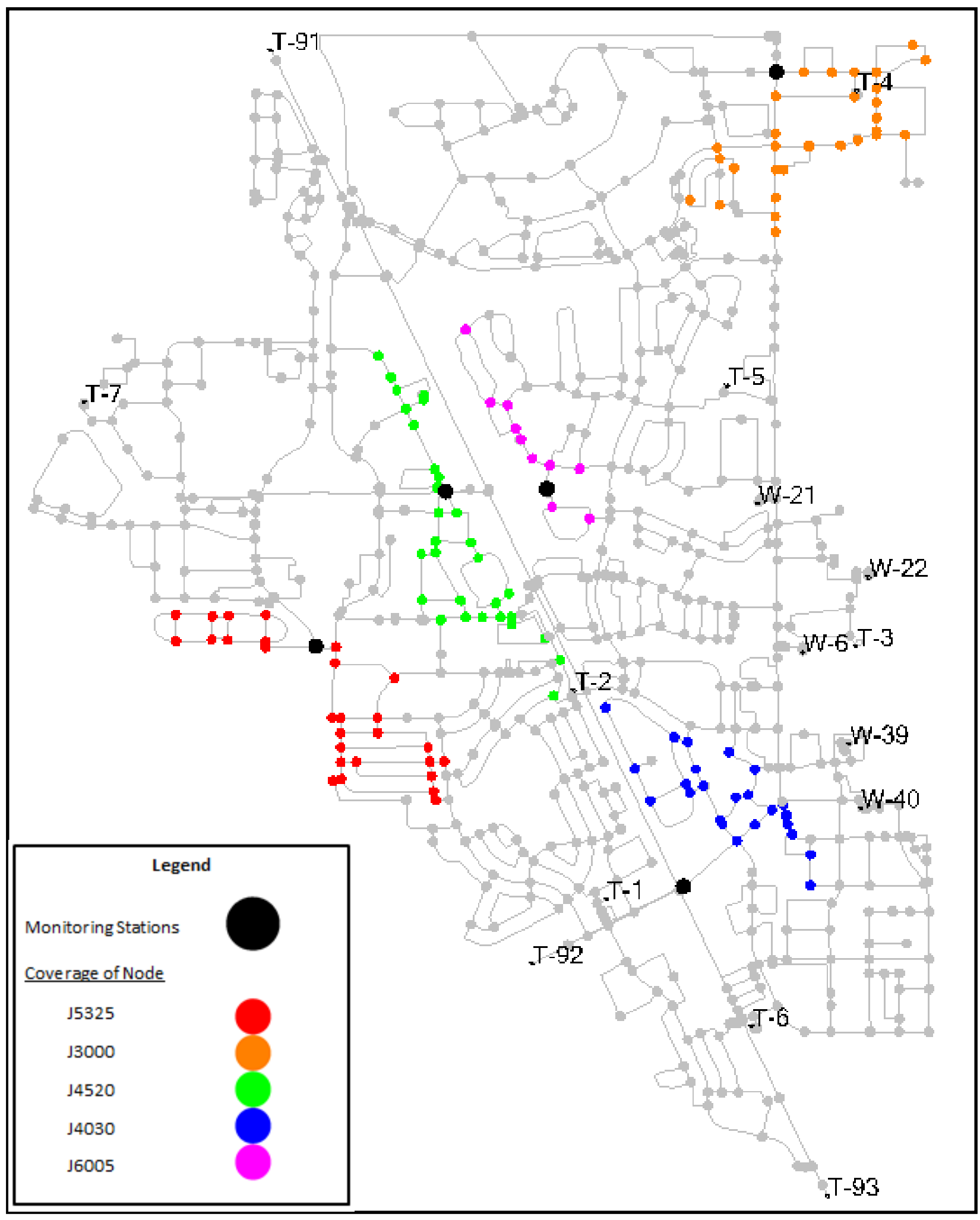

Figure 33: Monitoring Station 6-10 with Corresponding Coverages for Max Daily Demand (Steady State) 


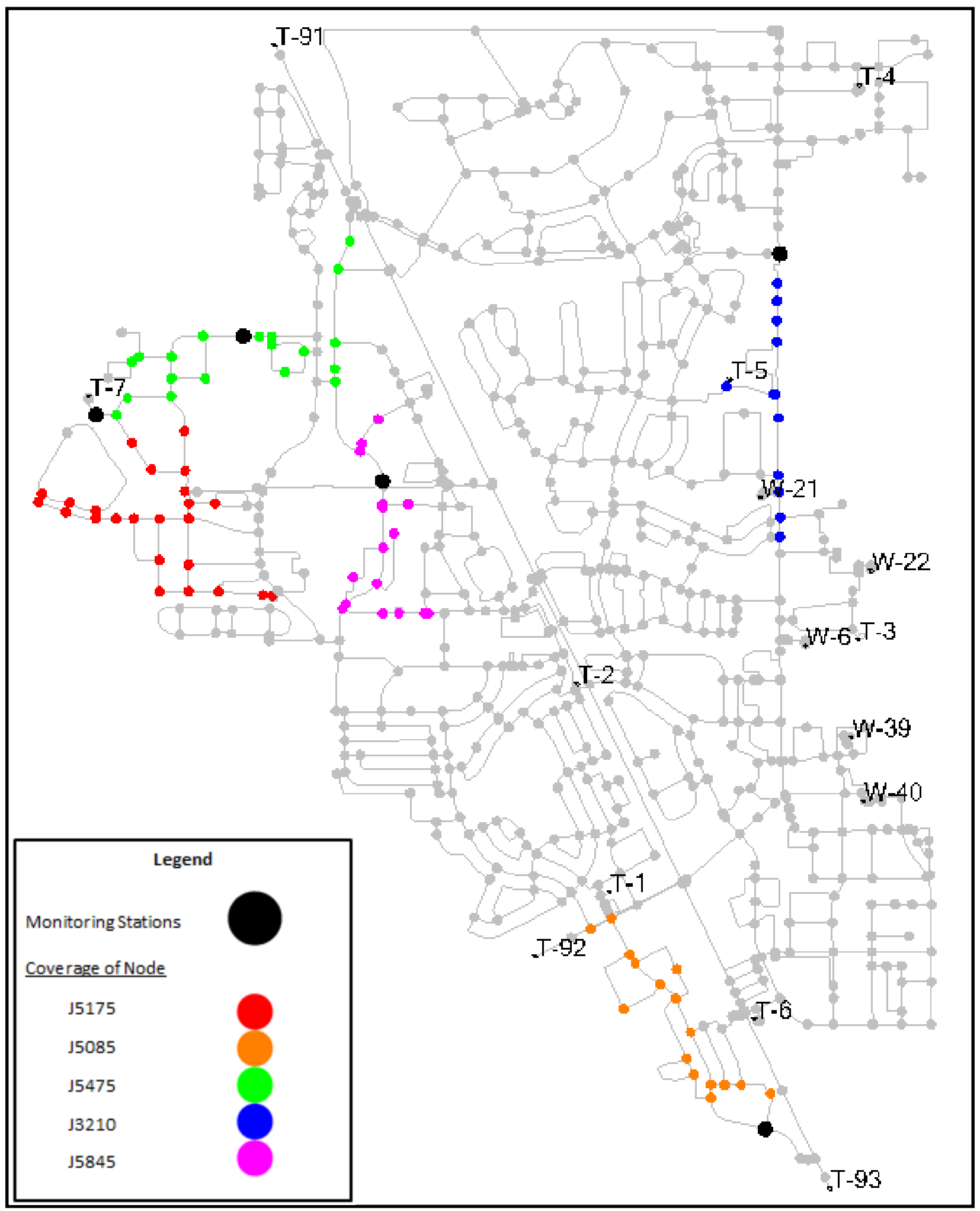

Figure 34: Monitoring Station 11-15 with Corresponding Coverages for Max Daily Demand (Steady State) 


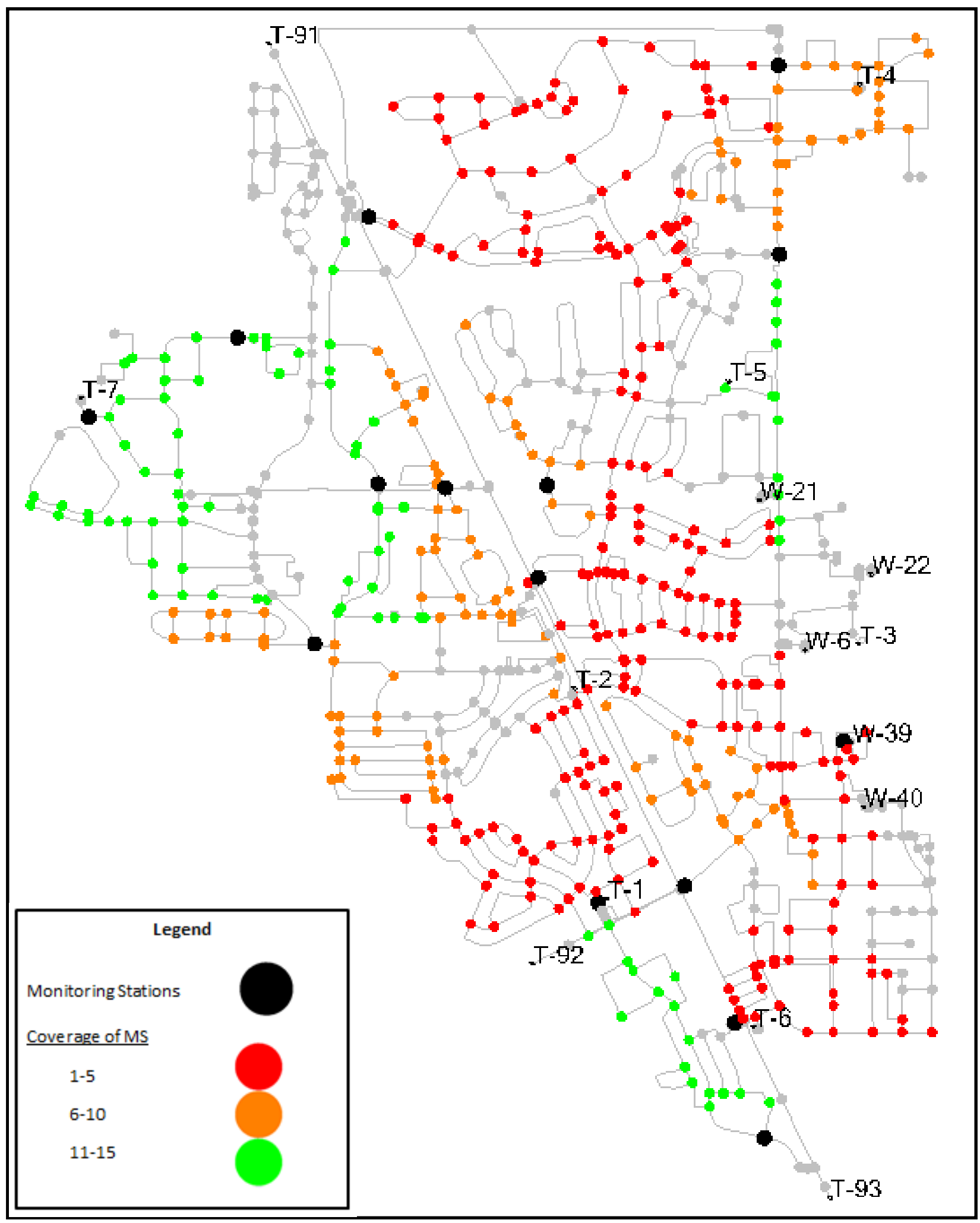

Figure 35: Top 15 Monitoring Stations with Corresponding Coverages for Max Daily Demand (Steady State) 


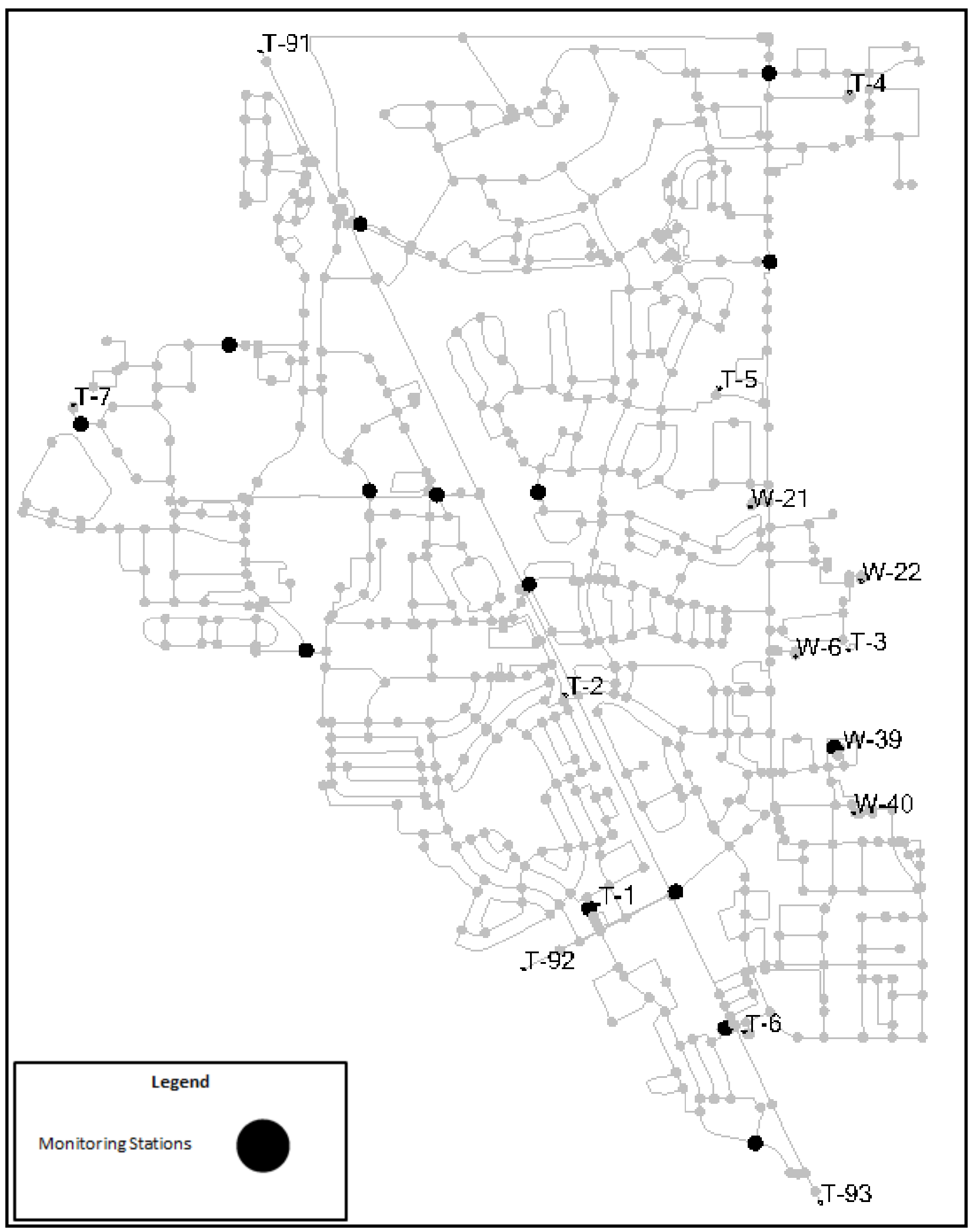

Figure 36: Top 15 Monitoring Stations for Max Daily Demand (Steady State) 


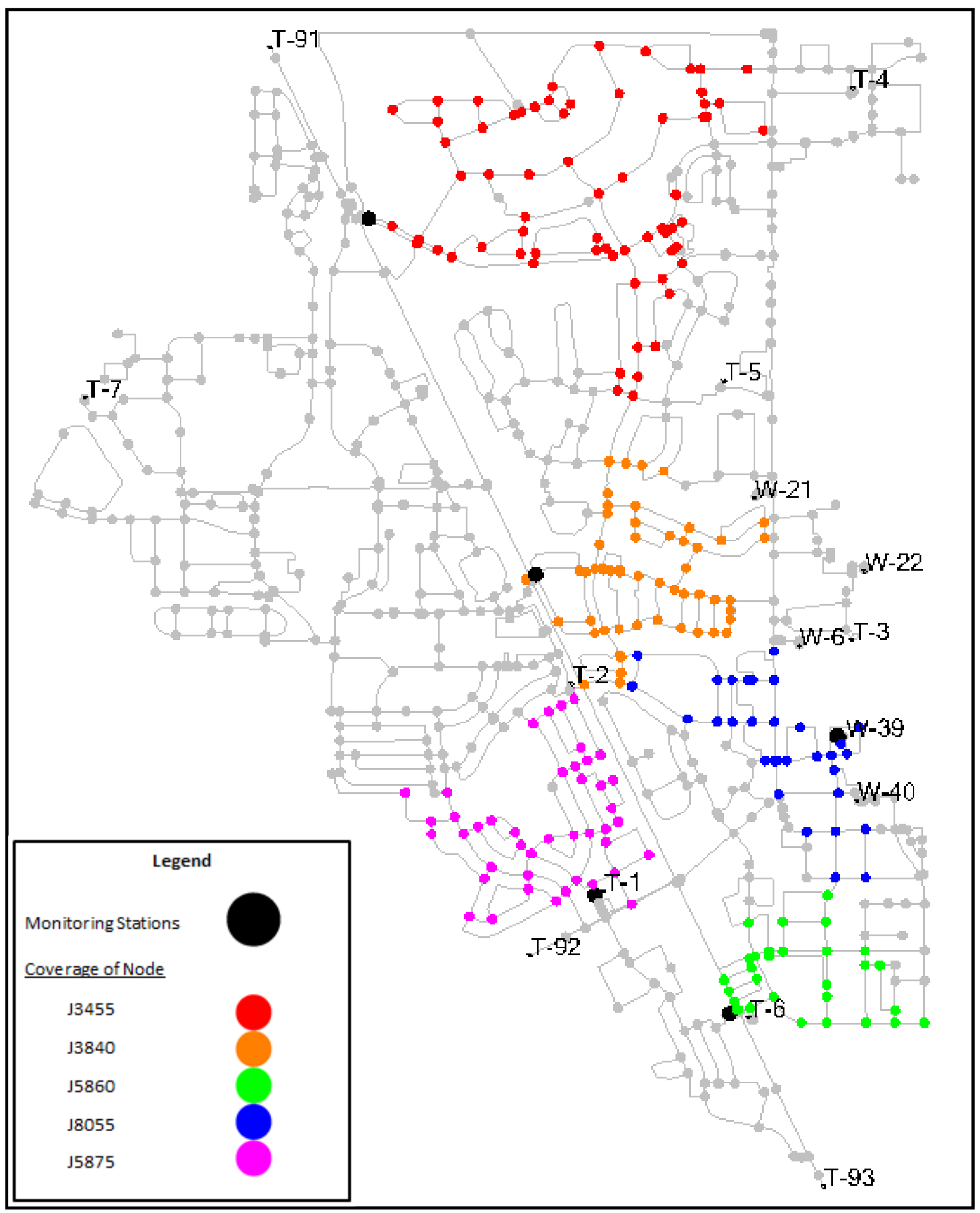

Figure 37: Monitoring Station 1-5 with Corresponding Coverages for Demand Pattern 2.0 (Unsteady State) 


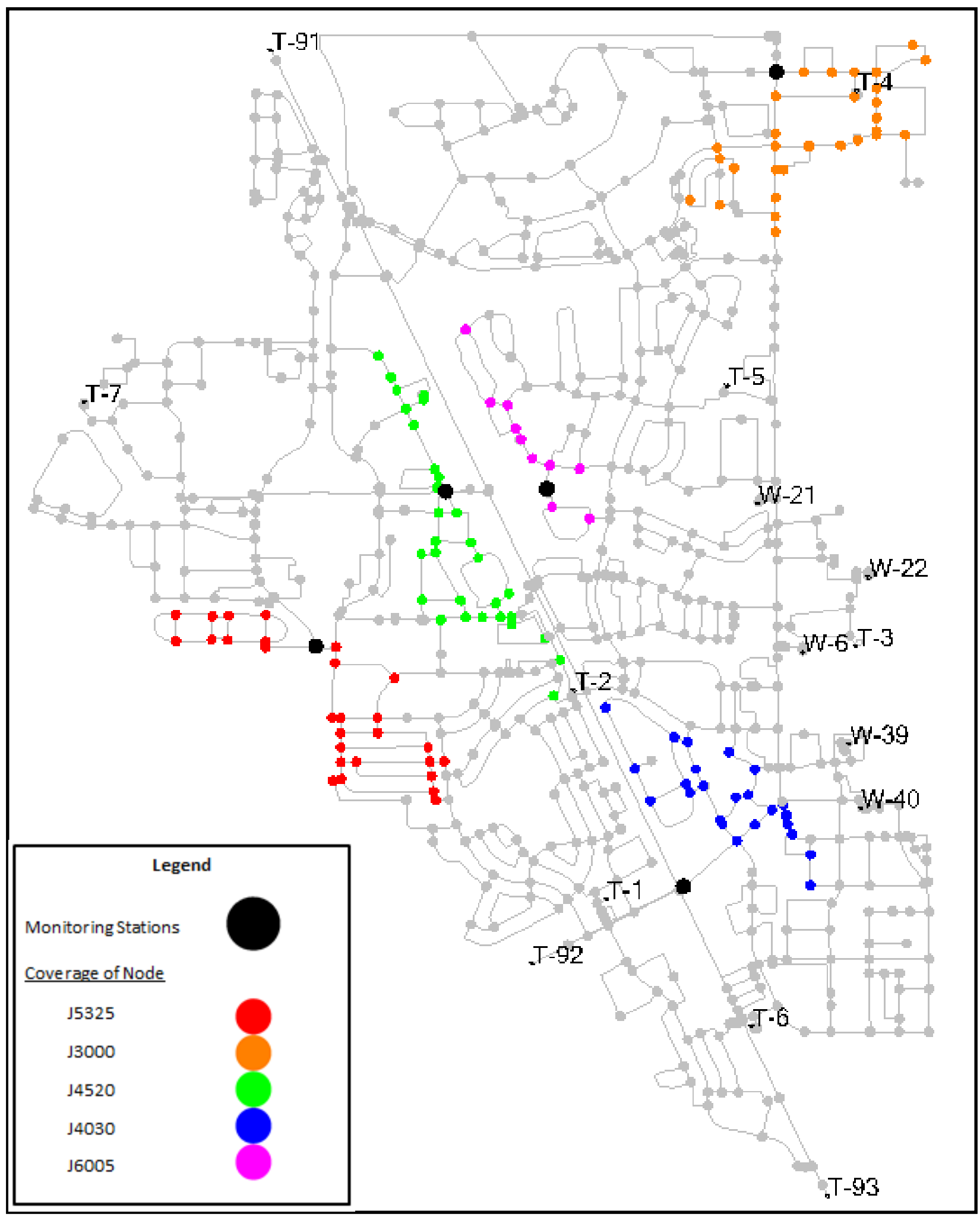

Figure 38: Monitoring Station 6-10 with Corresponding Coverages for Demand Pattern 2.0 (Unsteady State) 


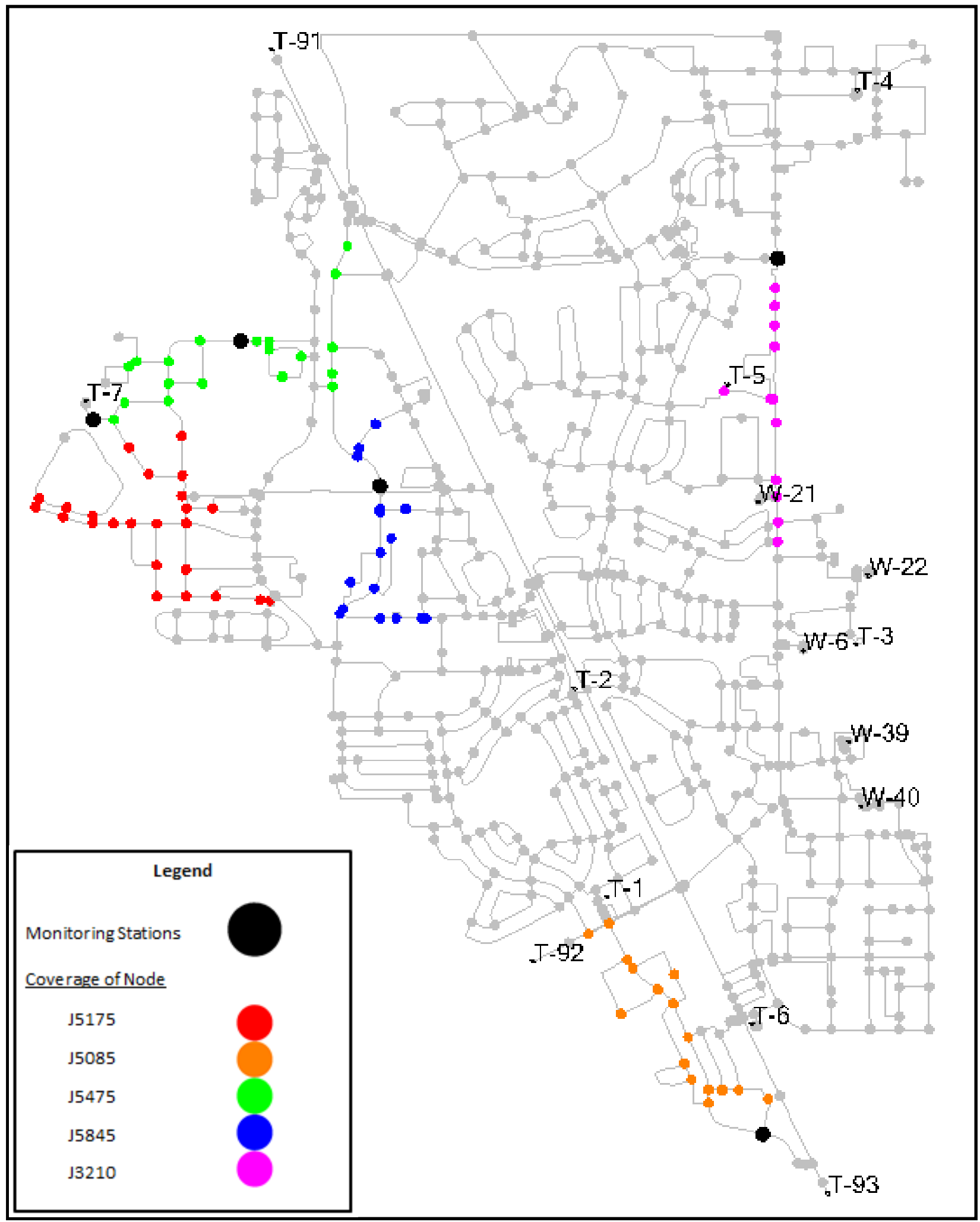

Figure 39: Monitoring Station 11-15 with Corresponding Coverages for Demand Pattern 2.0 (Unsteady State) 


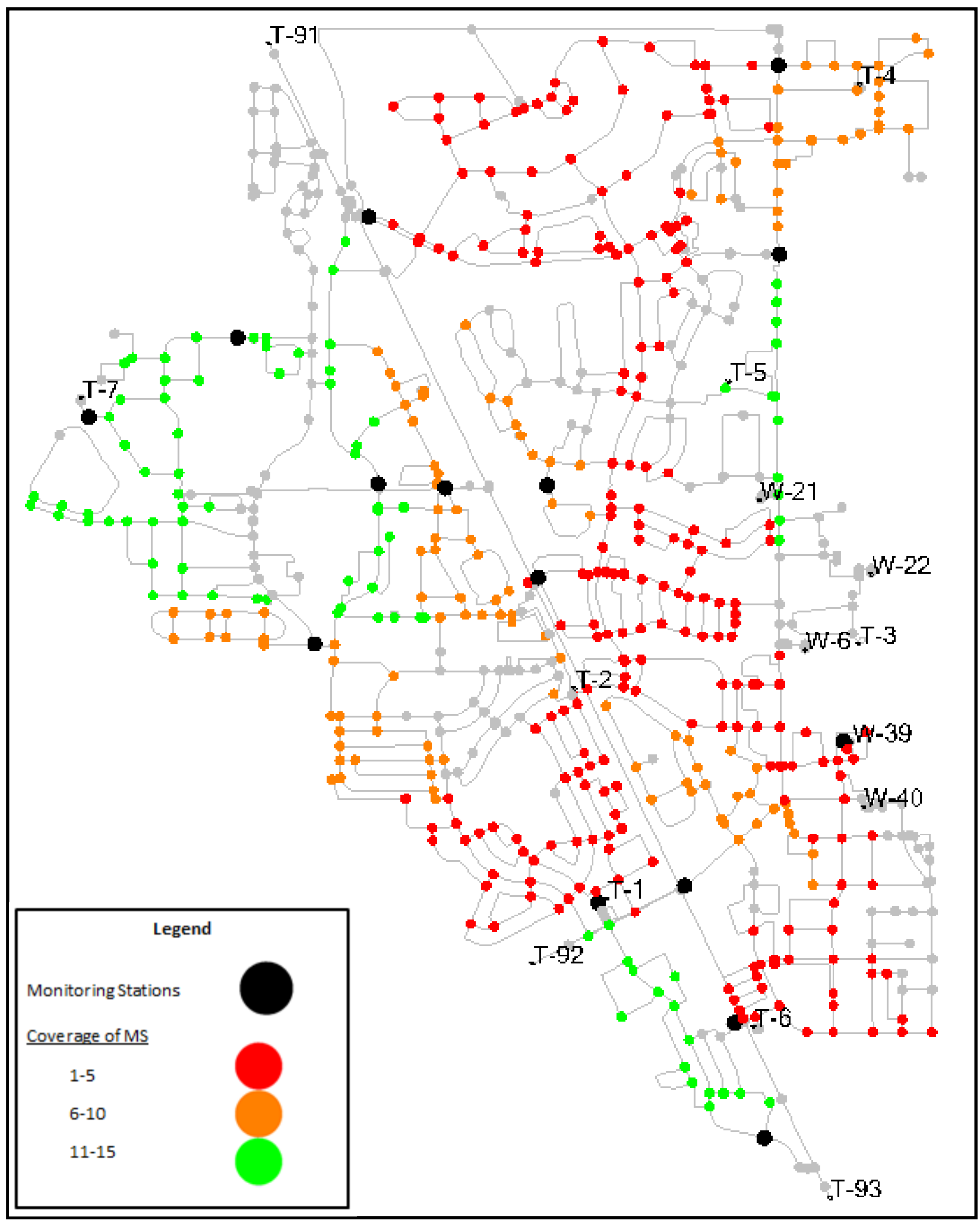

Figure 40: Top 15 Monitoring Stations with Corresponding Coverages for Demand Pattern 2.0 (Unsteady State) 


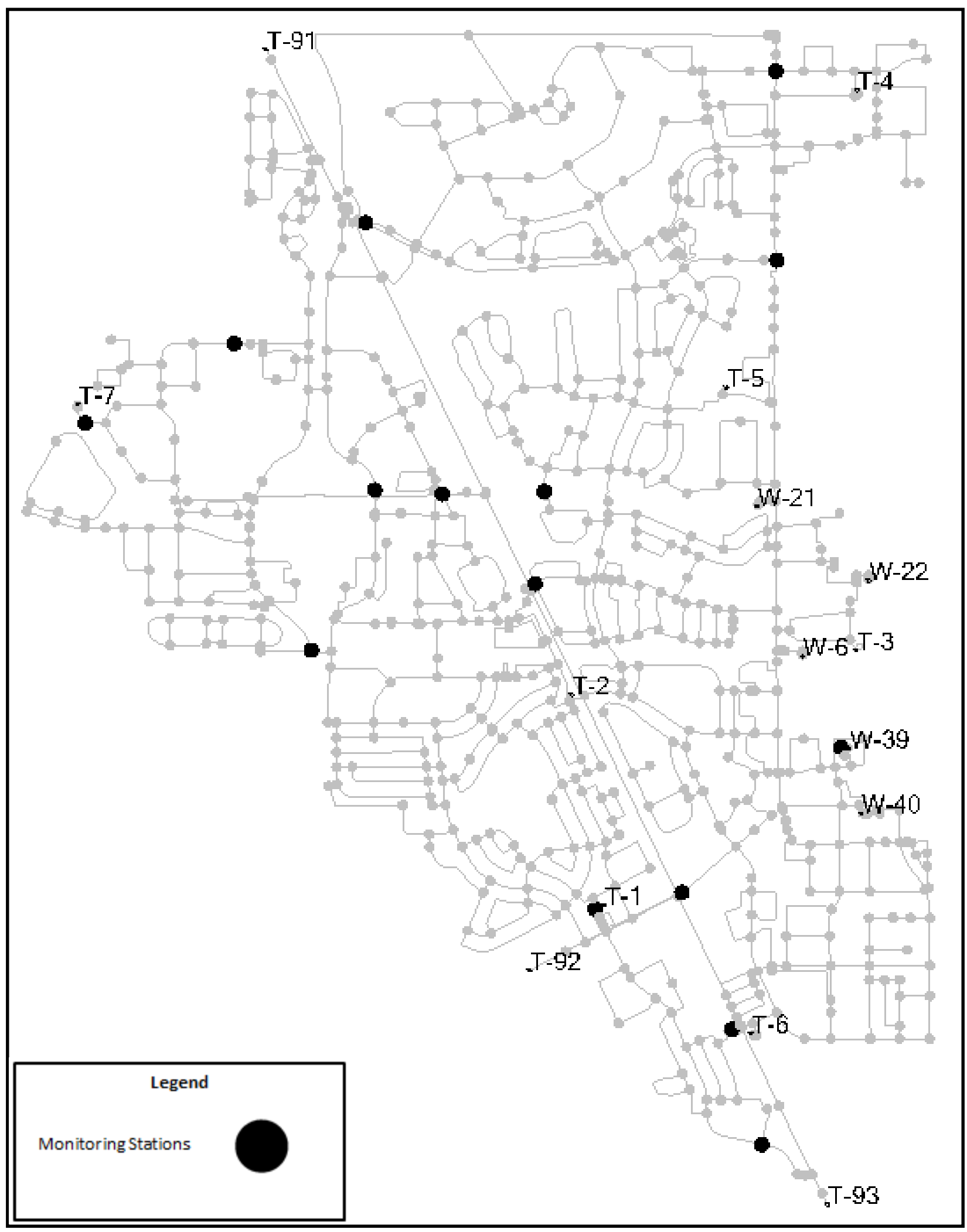

Figure 41: Top 15 Monitoring Stations for Demand Pattern 2.0 (Unsteady State) 


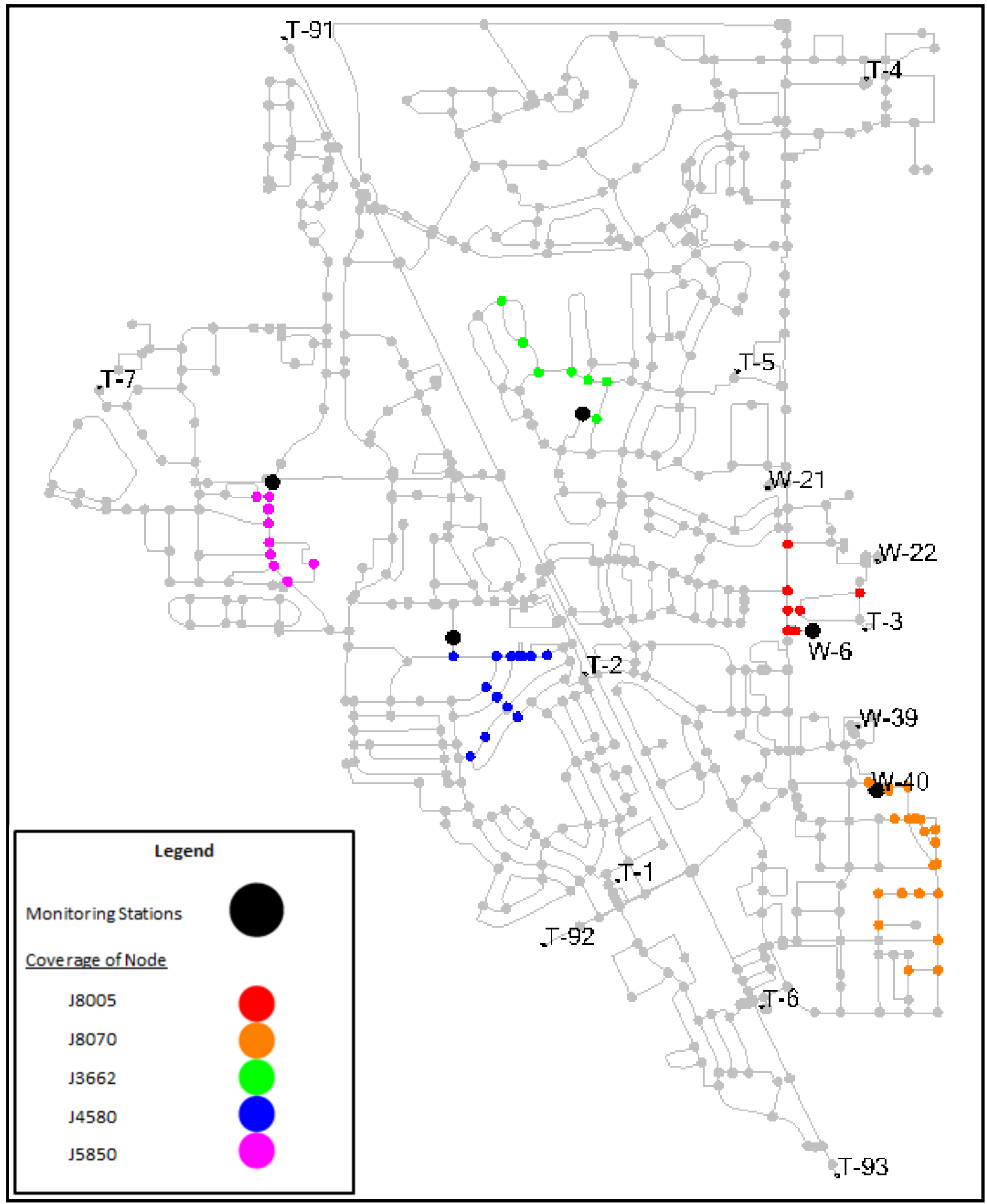

Figure 42: Monitoring Station 16-20 with Corresponding Coverages for Demand Pattern 2.0 (Unsteady State) 


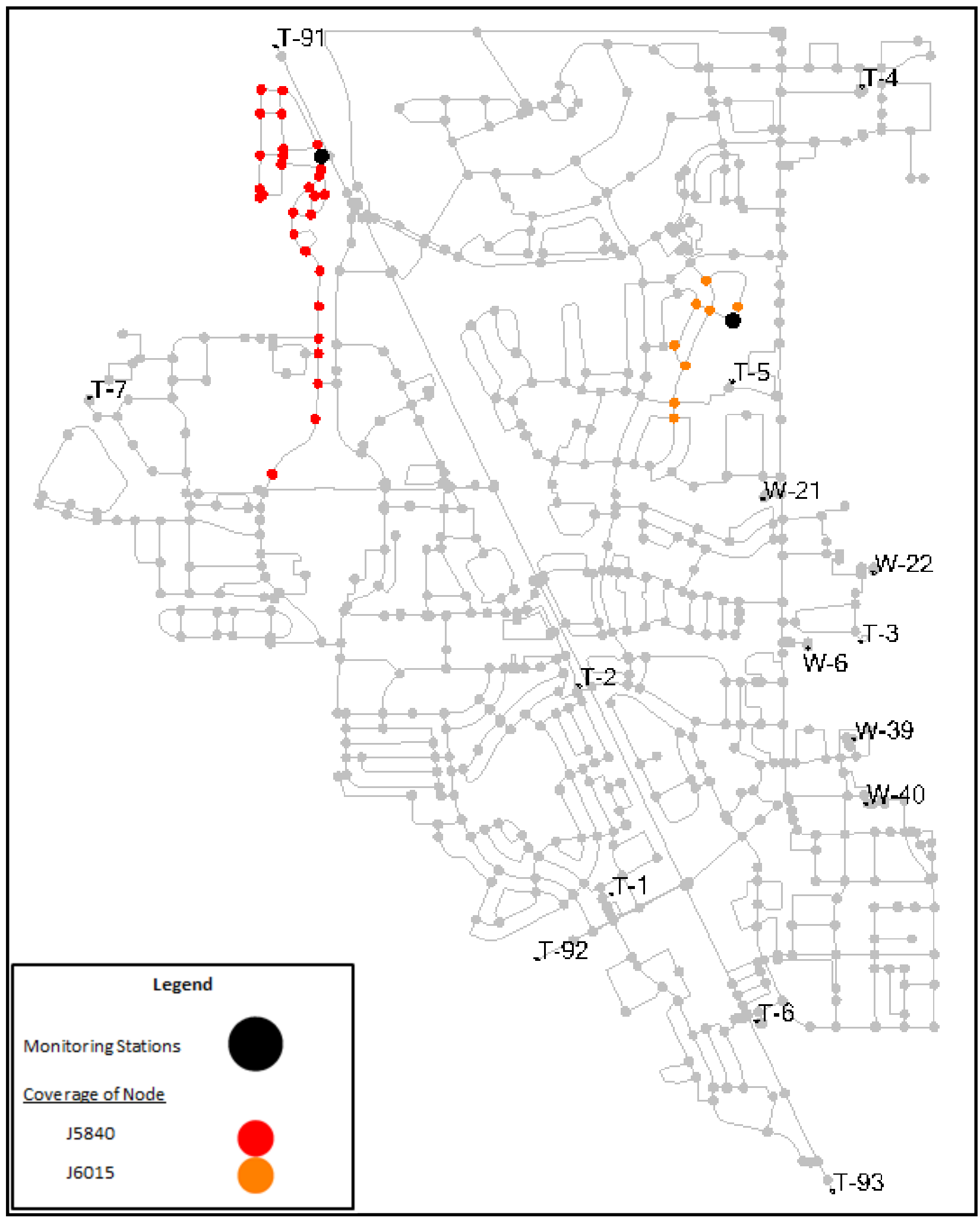

Figure 43: Monitoring Station 21-22 with Corresponding Coverages for Demand Pattern 2.0 (Unsteady State) 


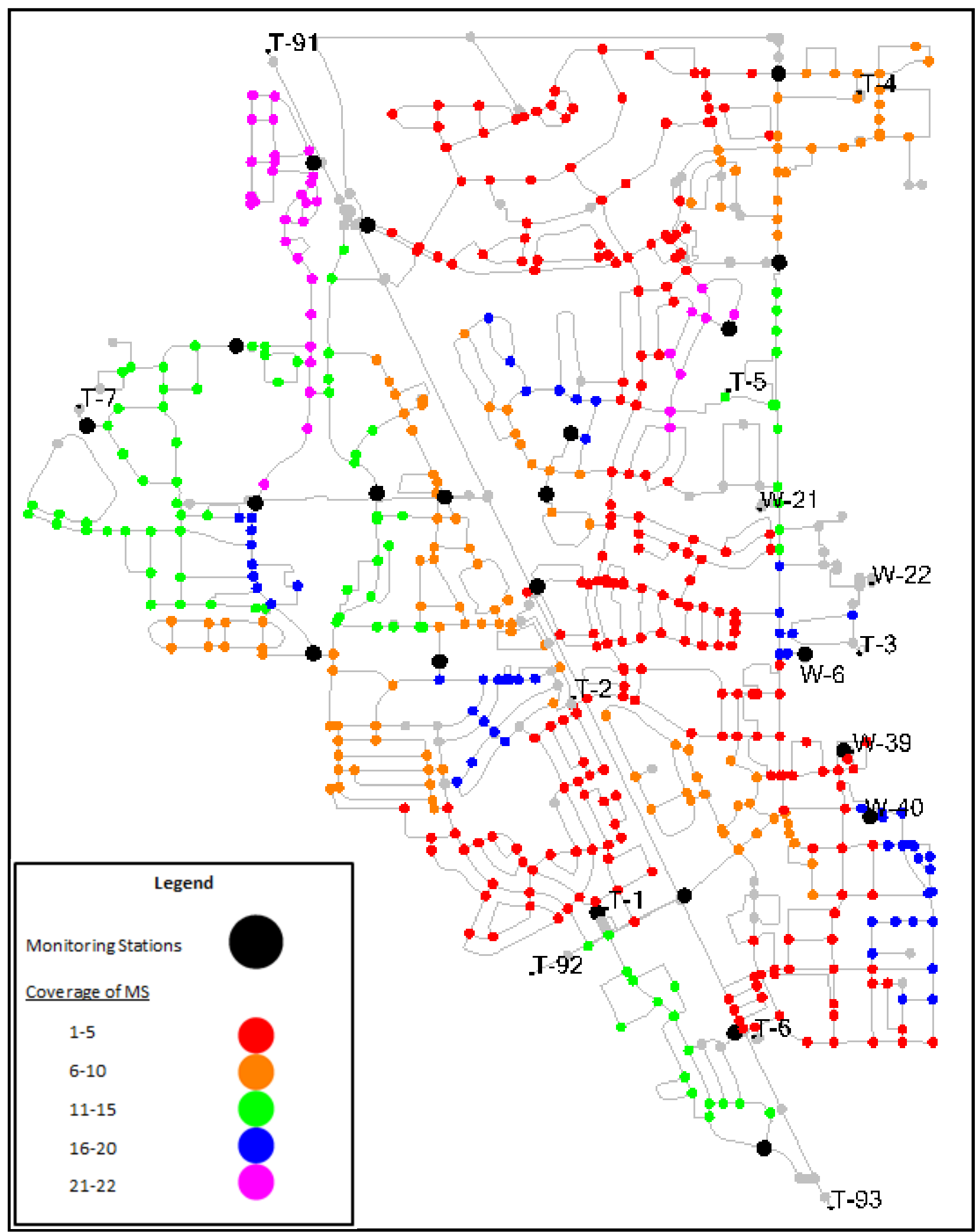

Figure 44: Top 22 Monitoring Stations with Corresponding Coverages for Demand Pattern 2.0 (Unsteady State) 


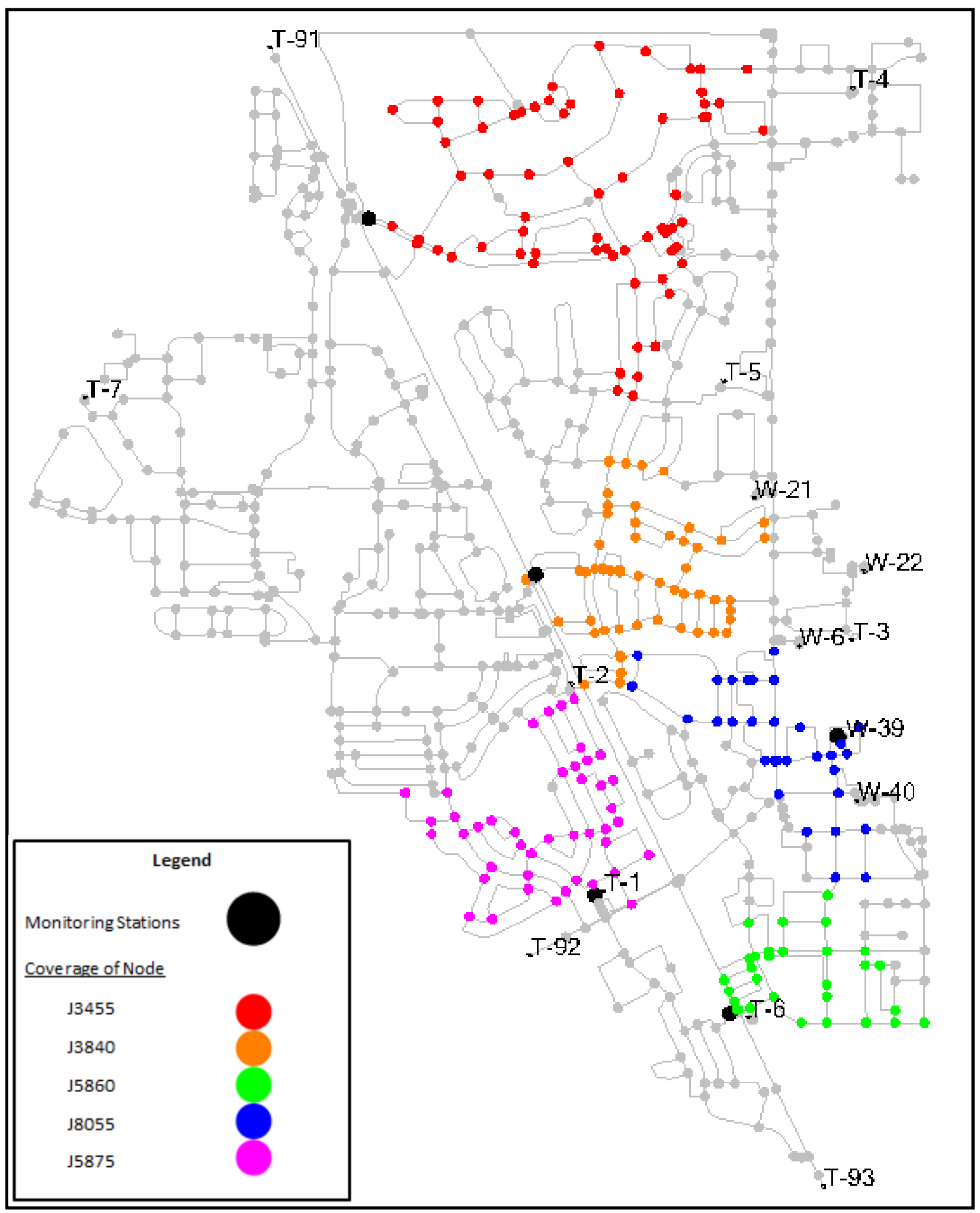

Figure 45: Monitoring Station 1-5 with Corresponding Coverages for Demand Pattern 3.0 (Unsteady State) 


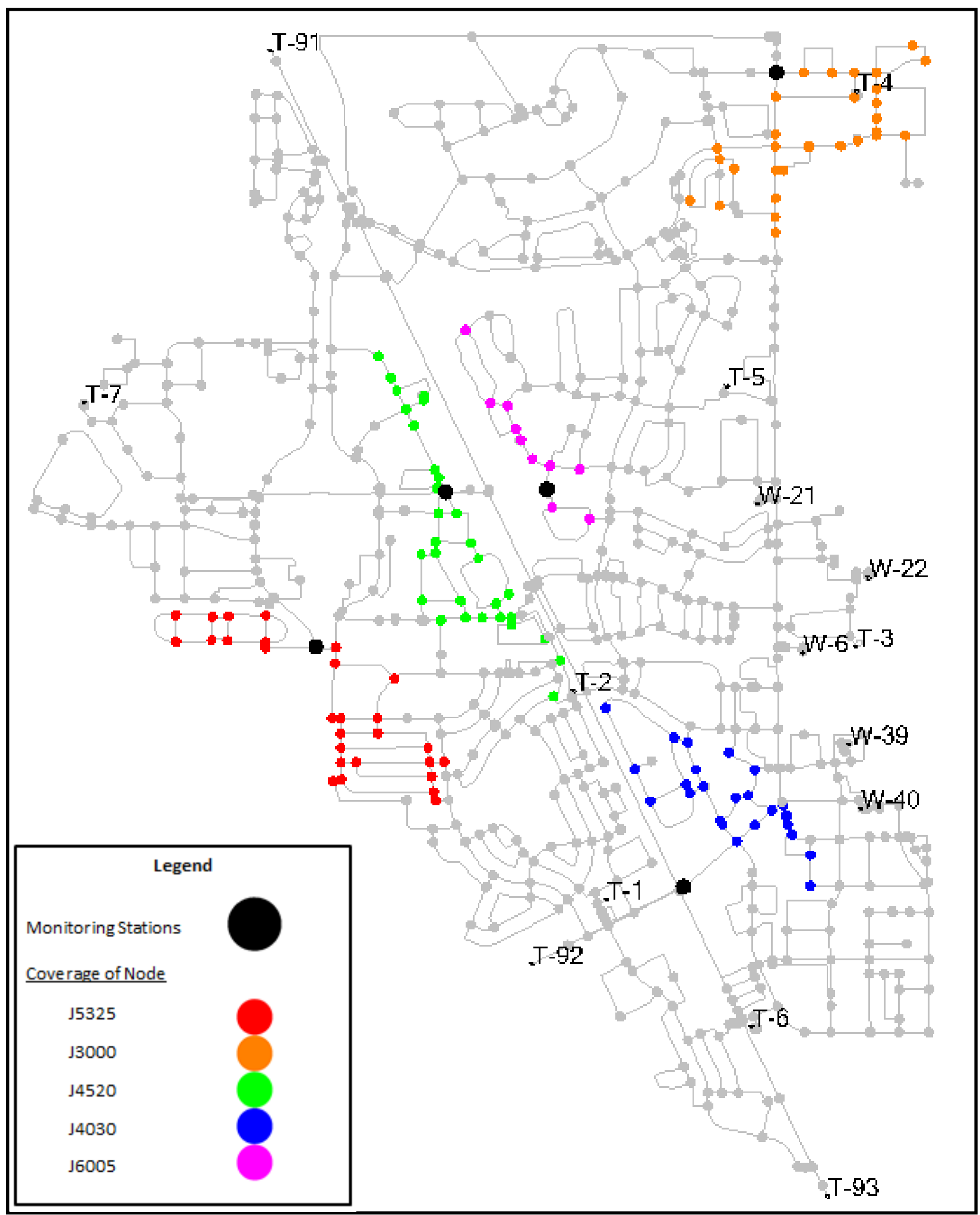

Figure 46: Monitoring Station 6-10 with Corresponding Coverages for Demand Pattern 3.0 (Unsteady State) 


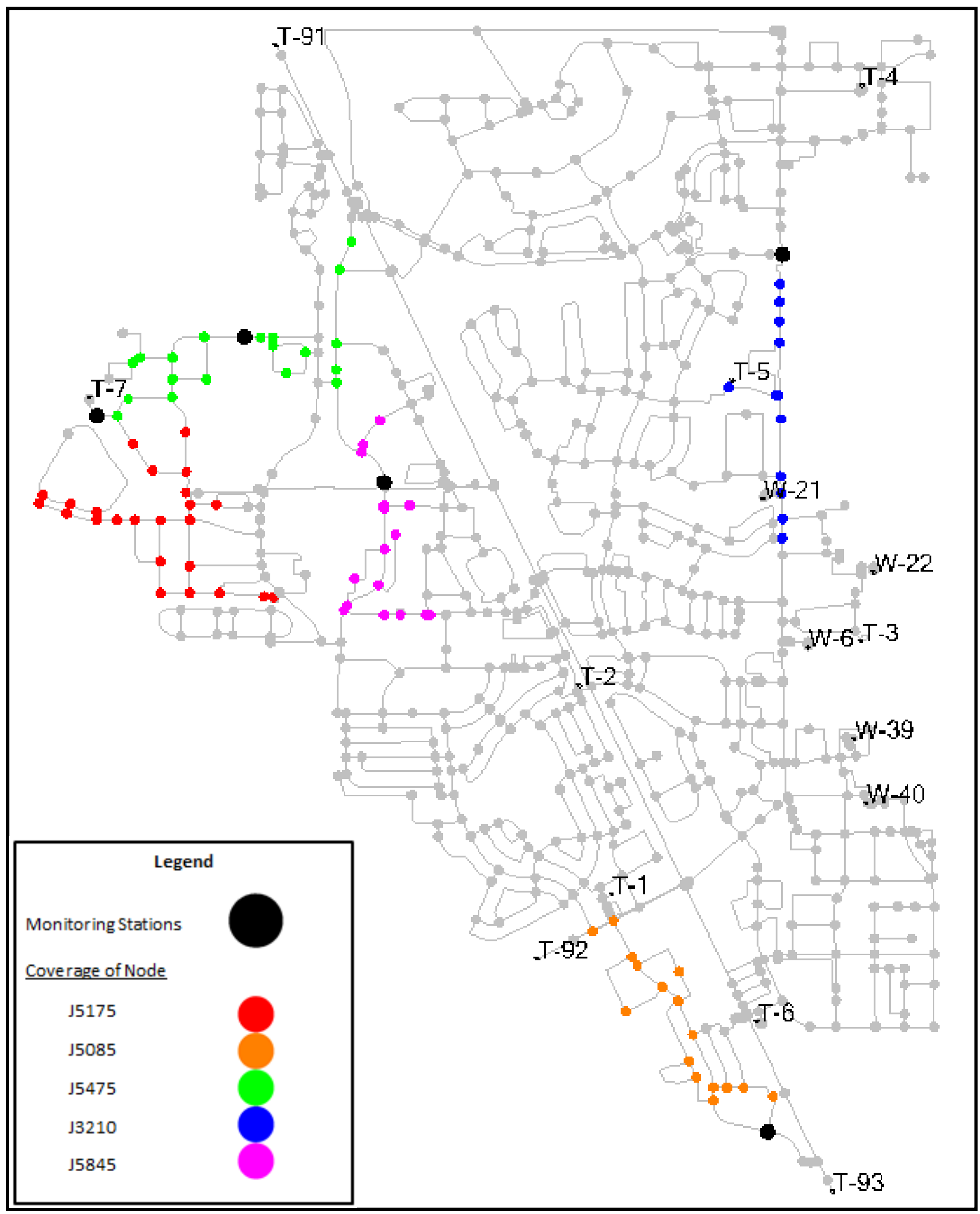

Figure 47: Monitoring Station 11-15 with Corresponding Coverages for Demand Pattern 3.0 (Unsteady State) 


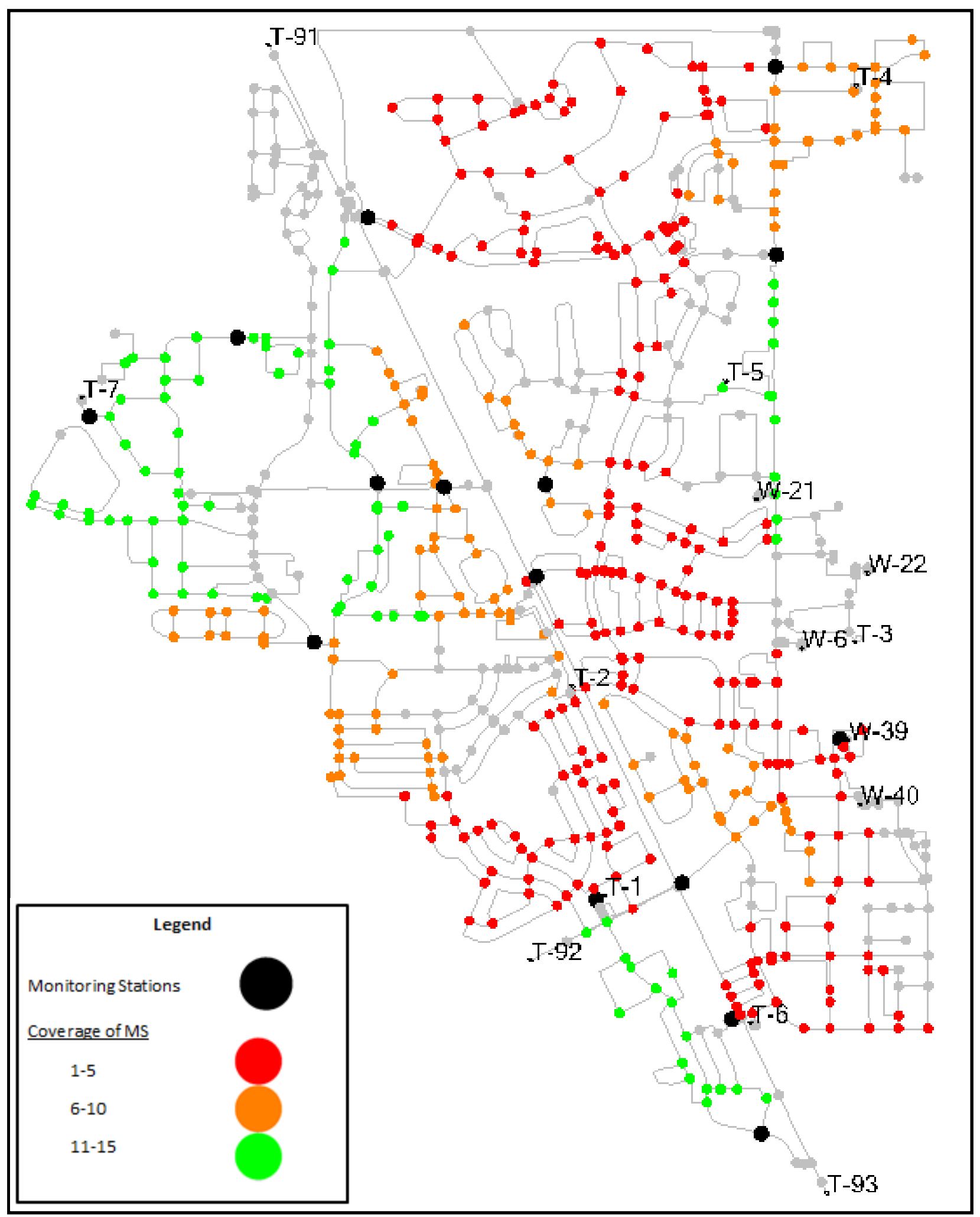

Figure 48: Top 15 Monitoring Stations with Corresponding Coverages for Demand Pattern 3.0 (Unsteady State) 


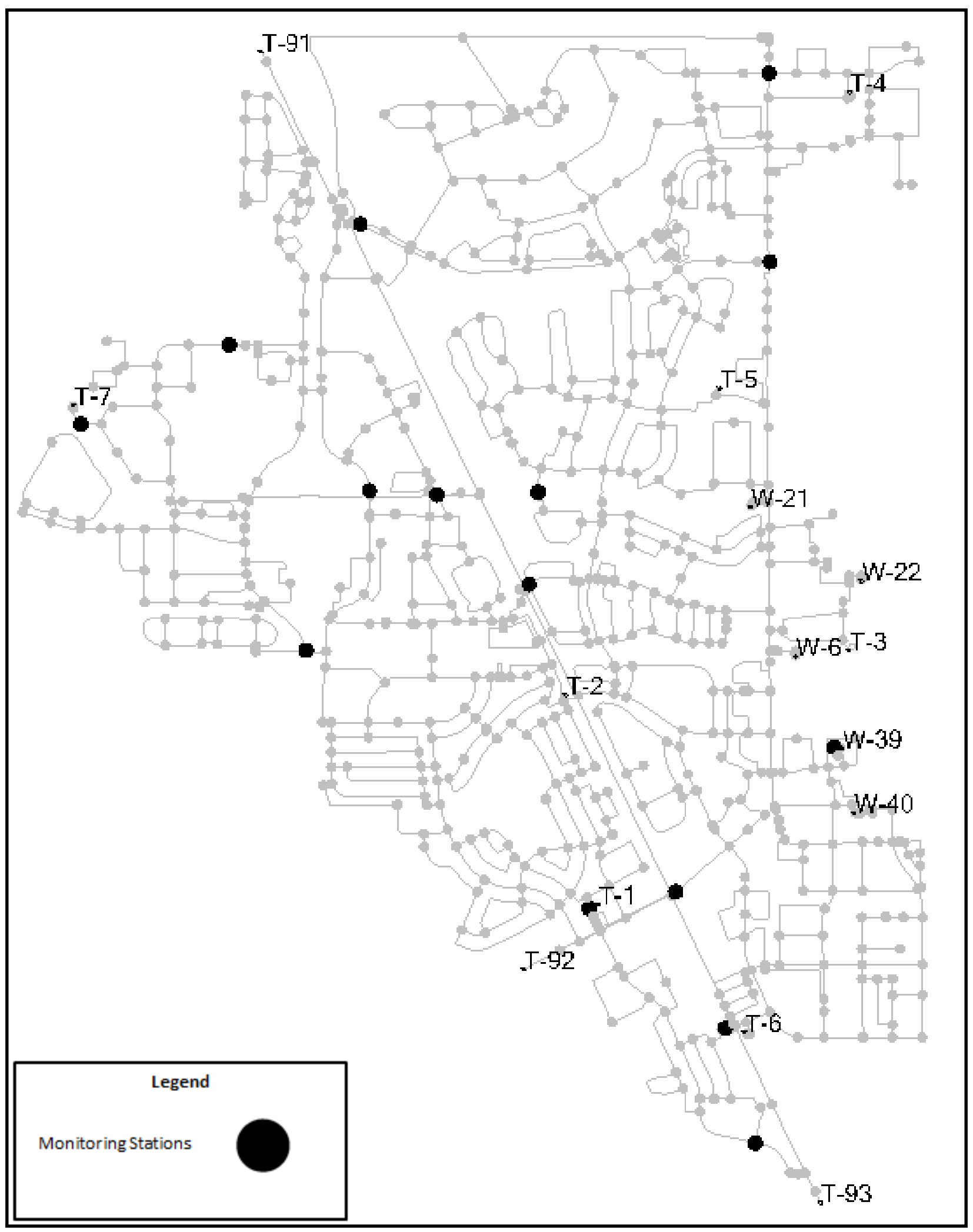

Figure 49: Top 15 Monitoring Stations for Demand Pattern 3.0 (Unsteady State) 


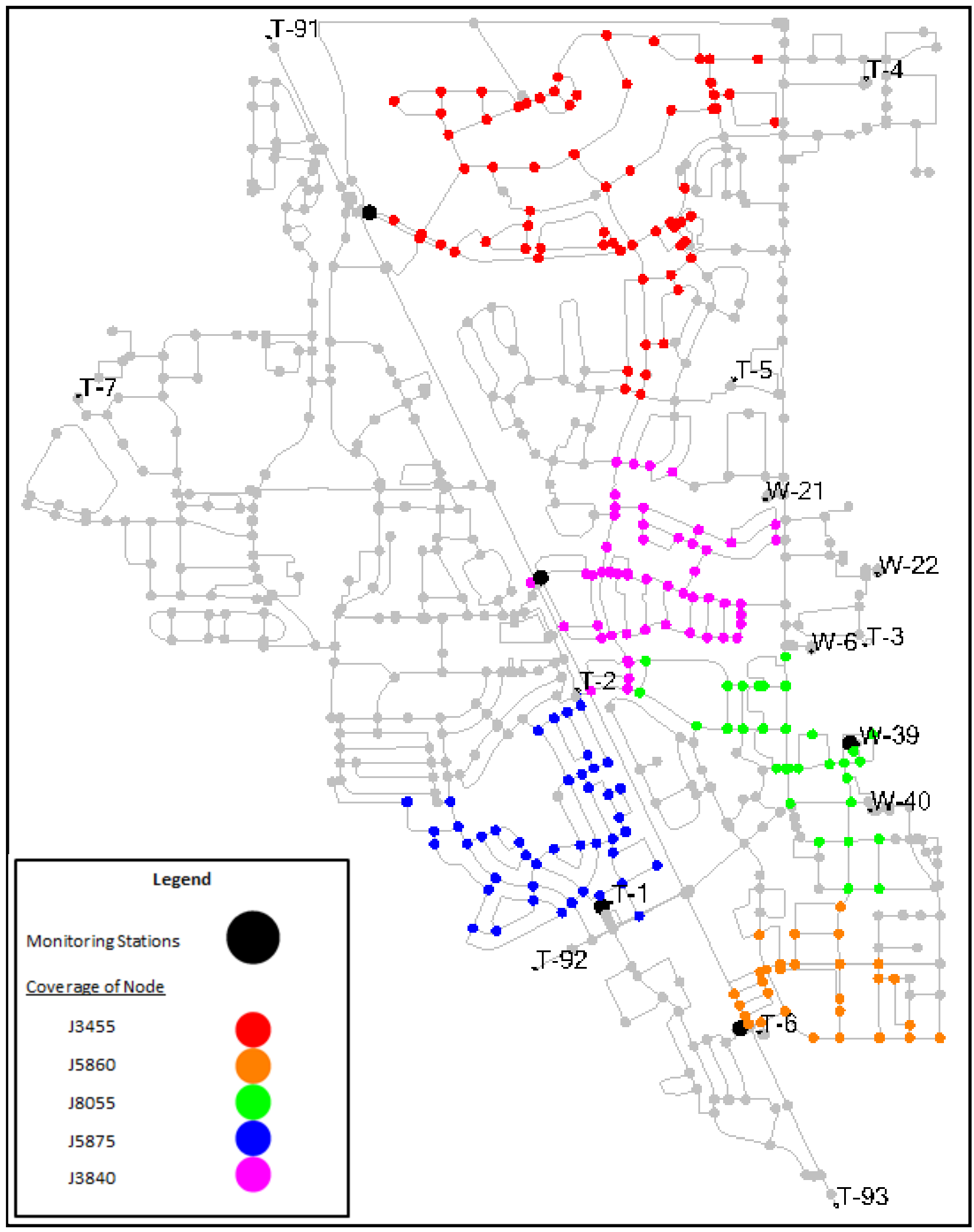

Figure 50: Monitoring Station 1-5 with Corresponding Coverages for Demand Pattern 4.0 (Unsteady State) 


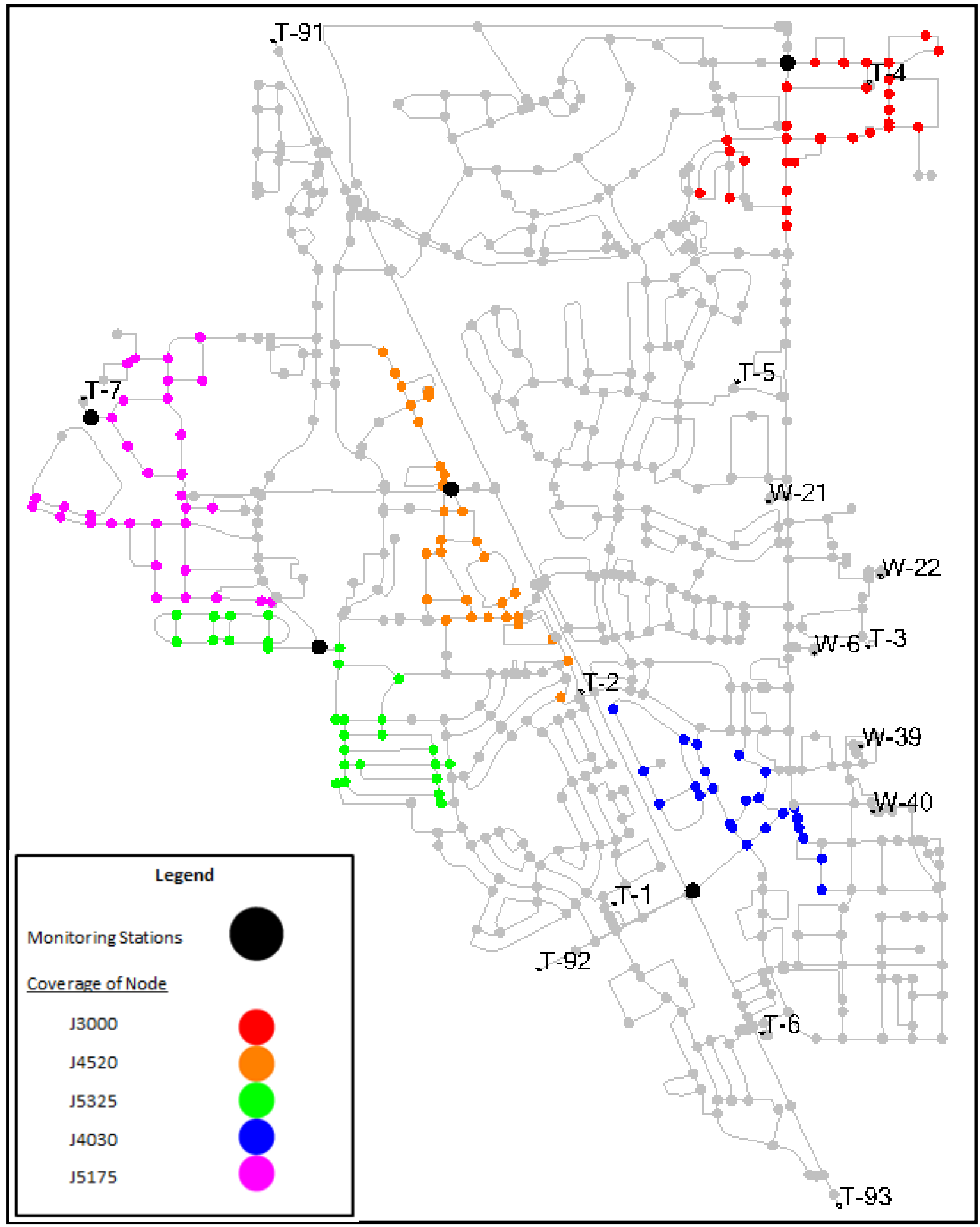

Figure 51: Monitoring Station 6-10 with Corresponding Coverages for Demand Pattern 4.0 (Unsteady State) 


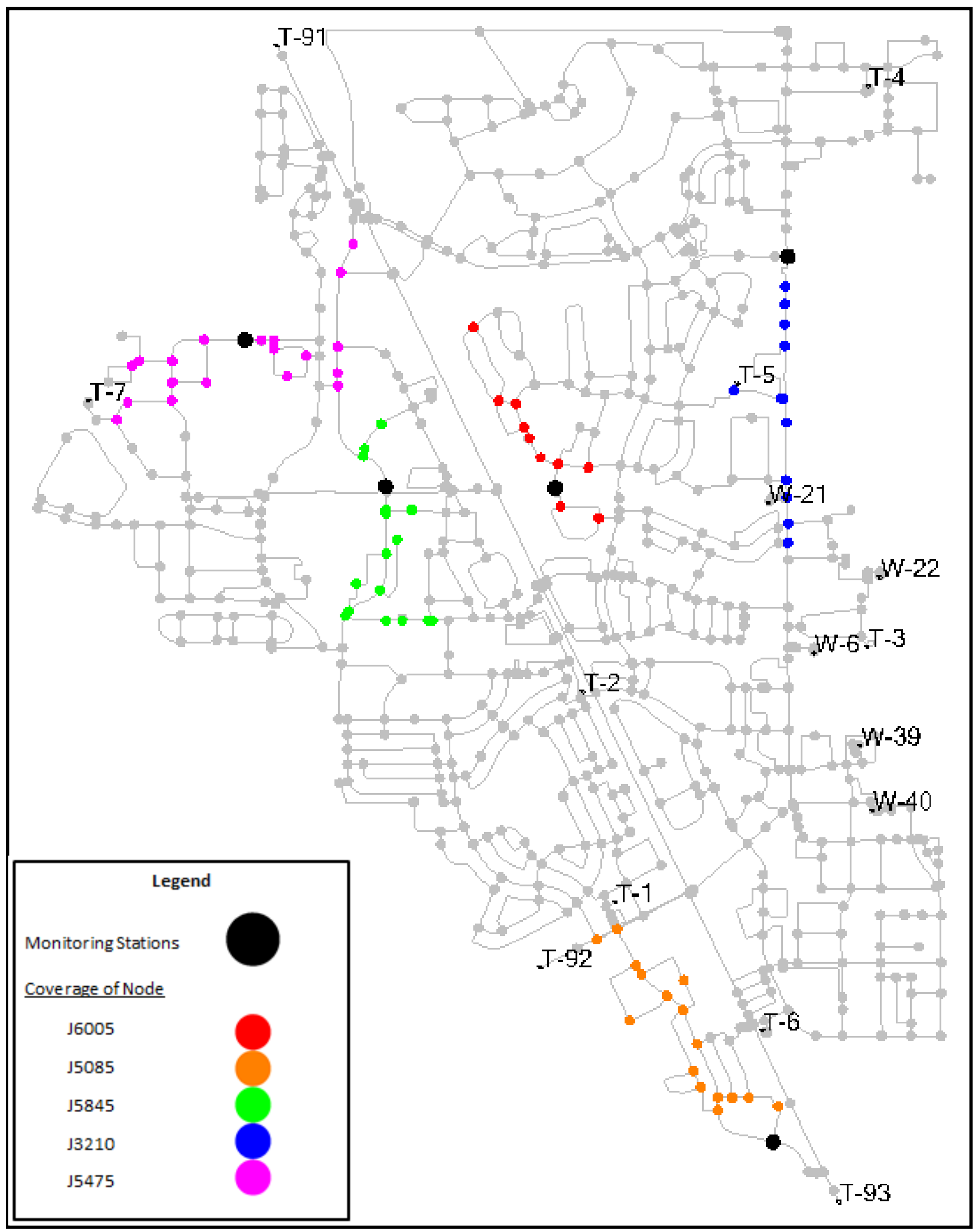

Figure 52: Monitoring Station 11-15 with Corresponding Coverages for Demand Pattern 4.0 (Unsteady State) 


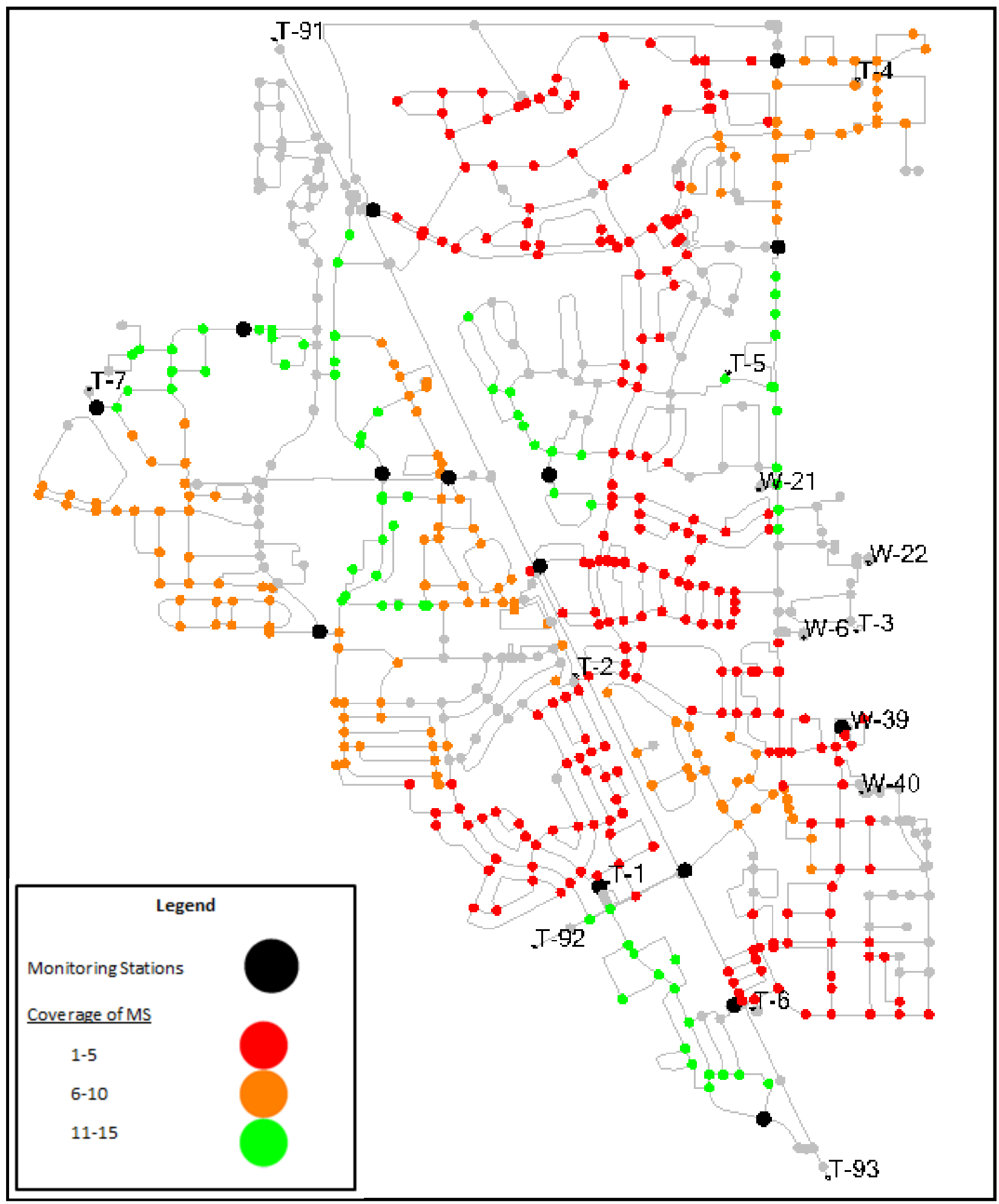

Figure 53: Top 15 Monitoring Stations with Corresponding Coverages for Demand Pattern 4.0 (Unsteady State) 


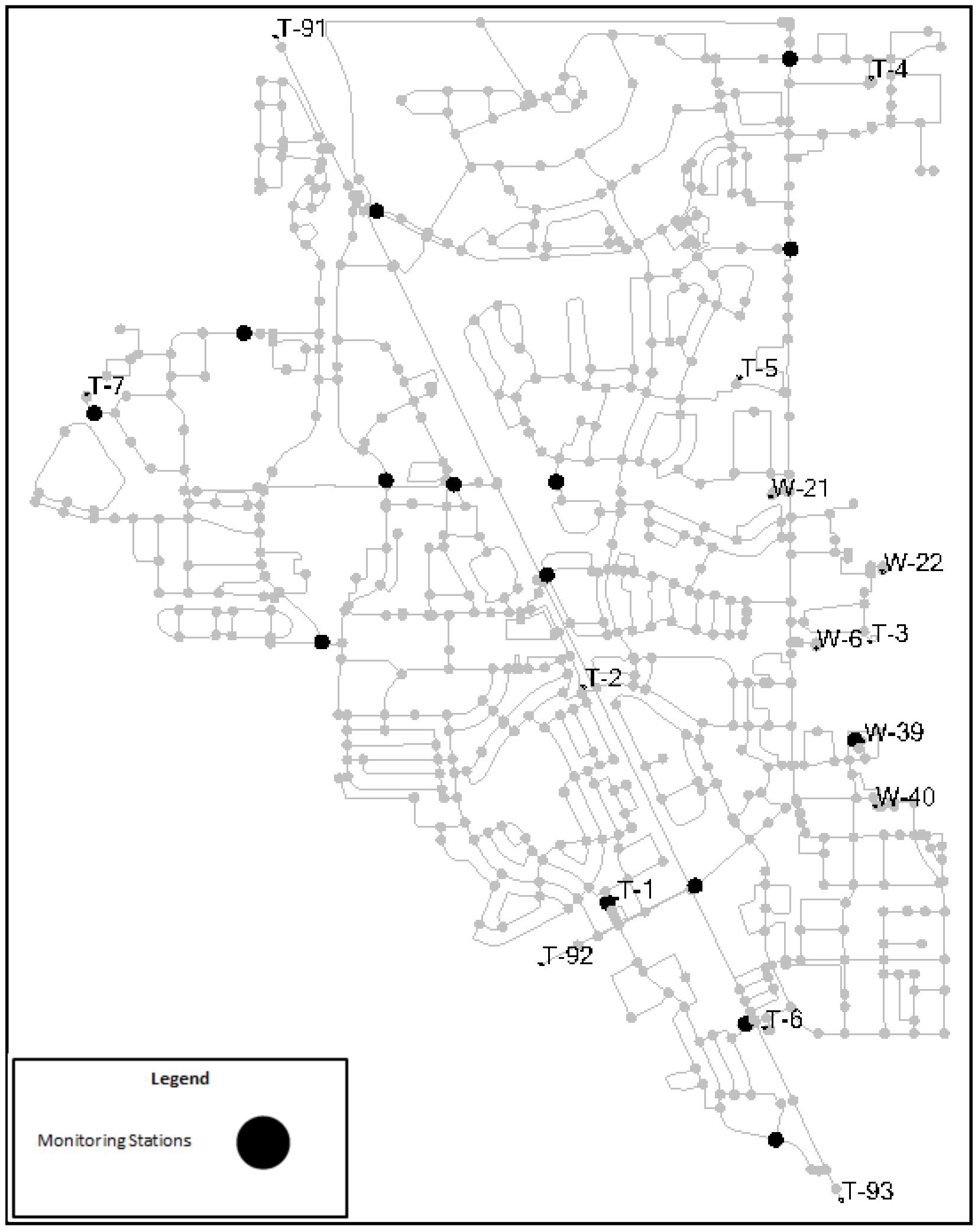

Figure 54: Top 15 Monitoring Stations for Demand Pattern 4.0 (Unsteady State) 


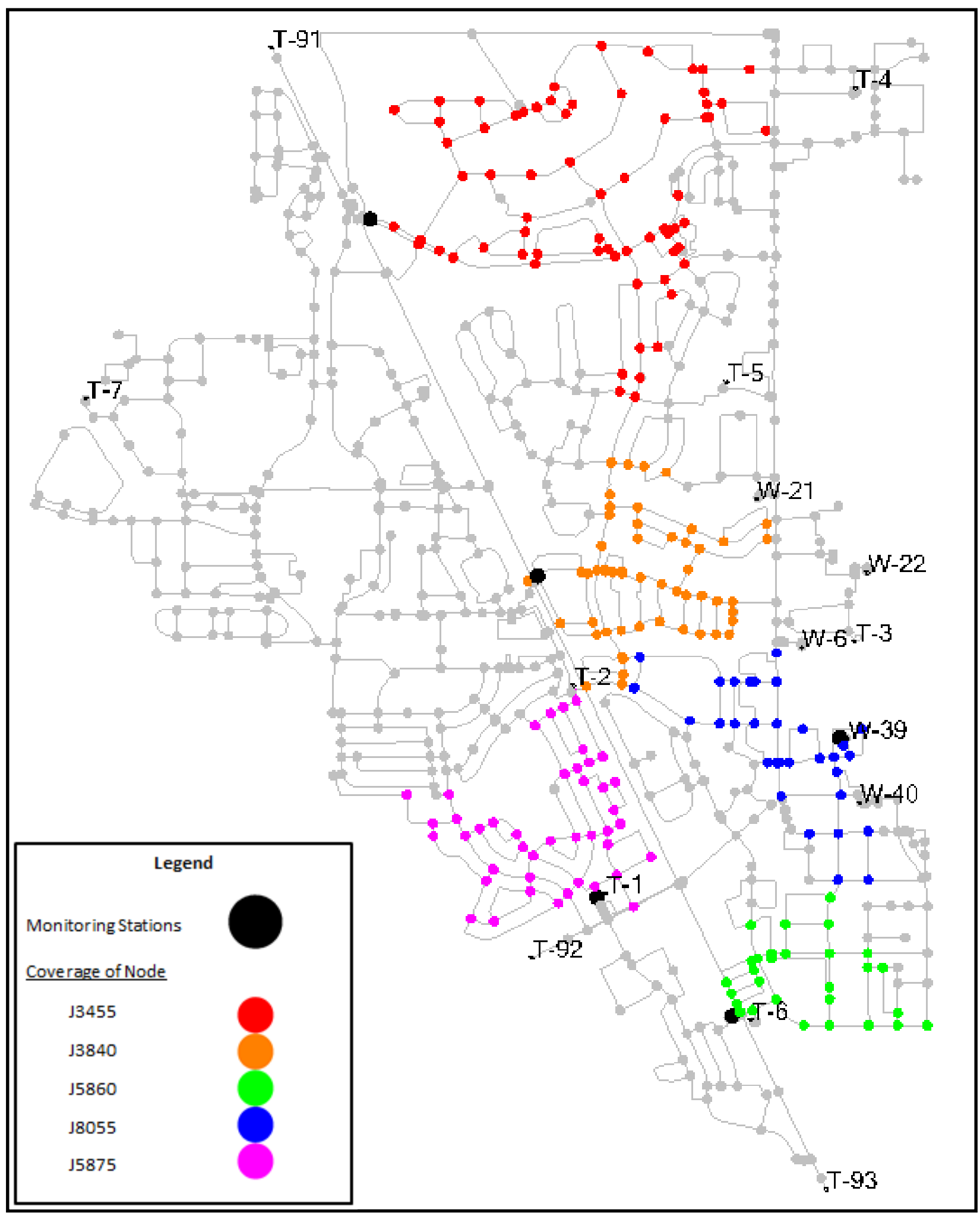

Figure 55: Monitoring Station 1-5 with Corresponding Coverages for Demand Pattern 5.0 (Unsteady State) 


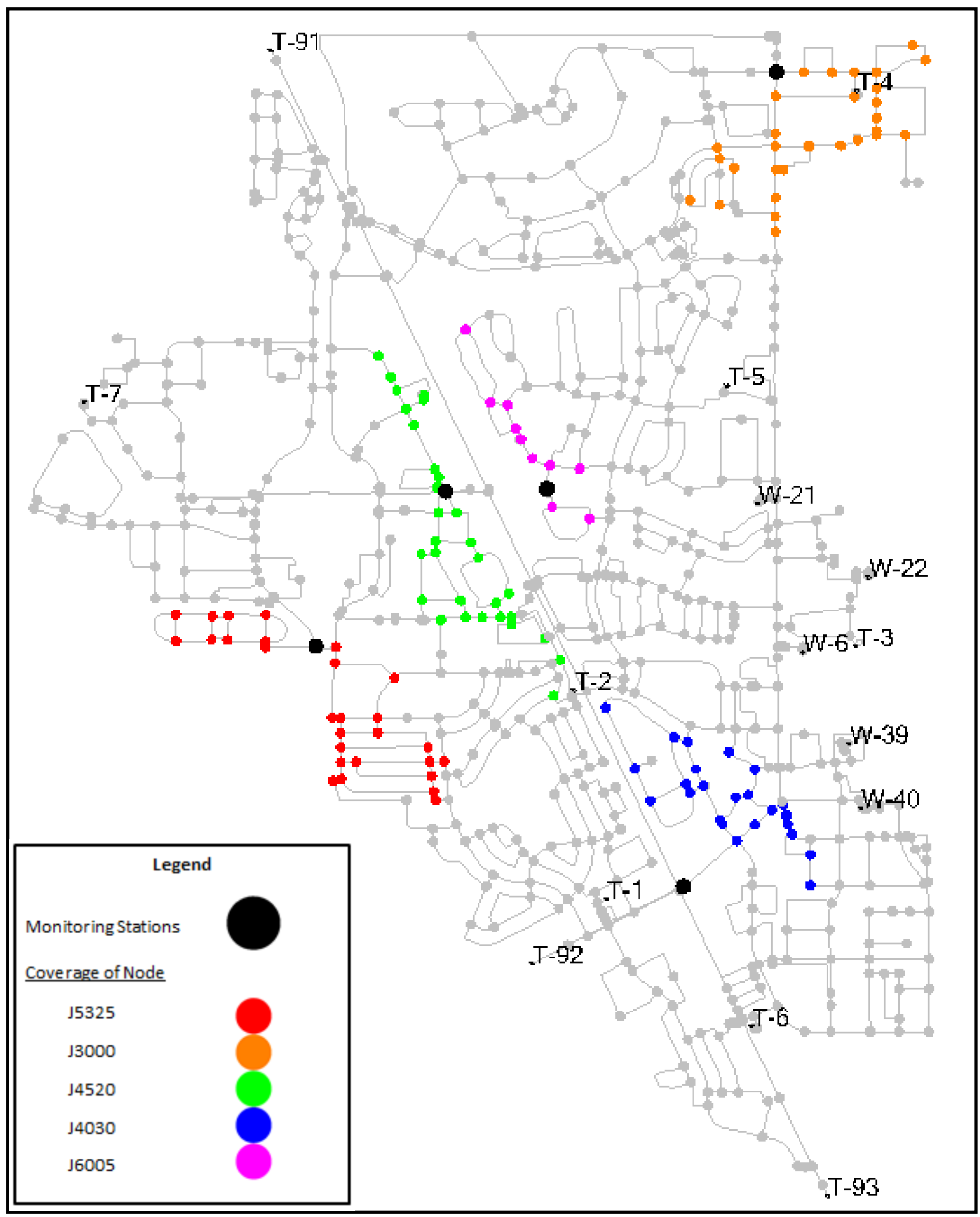

Figure 56: Monitoring Station 6-10 with Corresponding Coverages for Demand Pattern 5.0 (Unsteady State) 


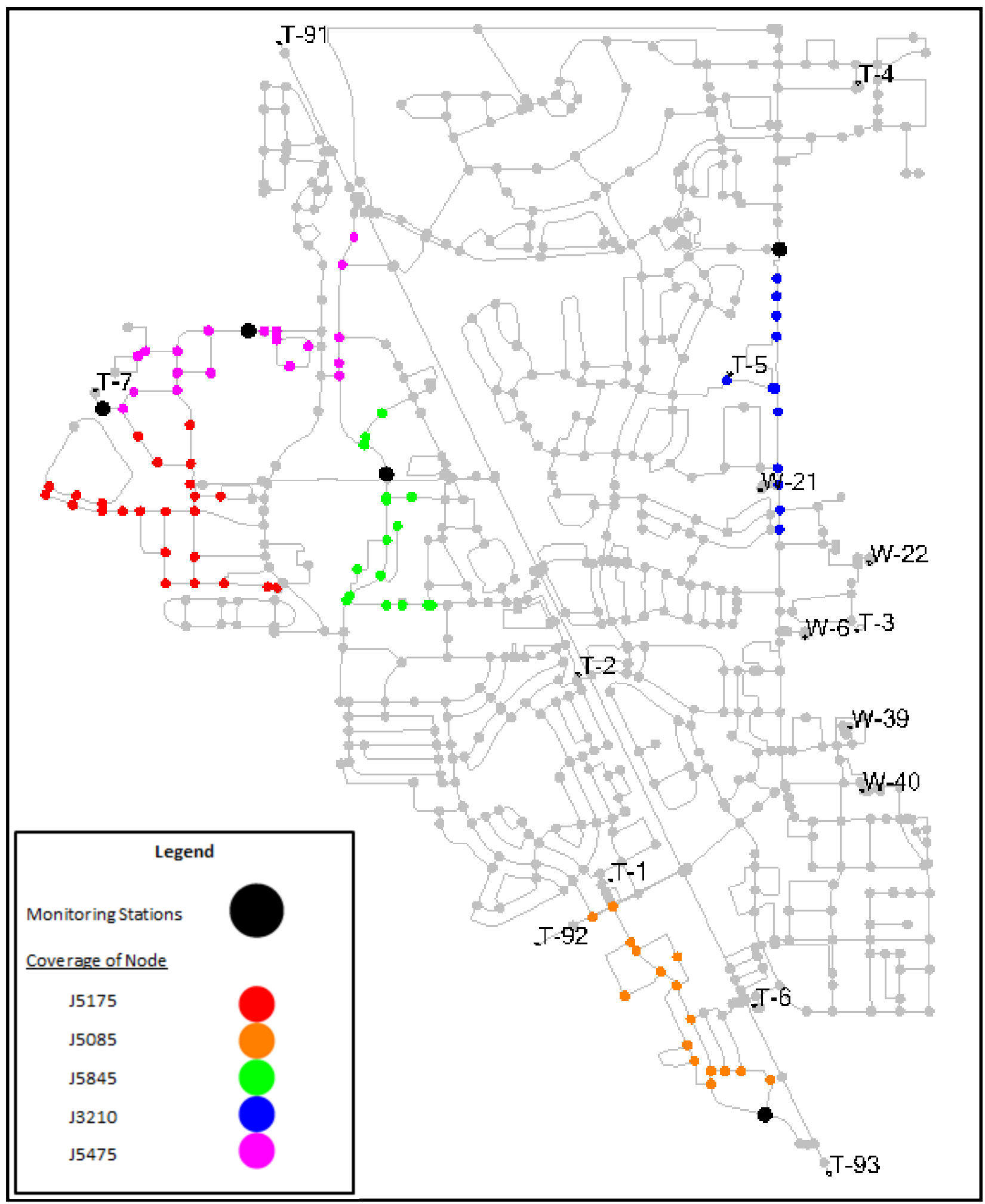

Figure 57: Monitoring Station 11-15 with Corresponding Coverages for Demand Pattern 5.0 (Unsteady State) 


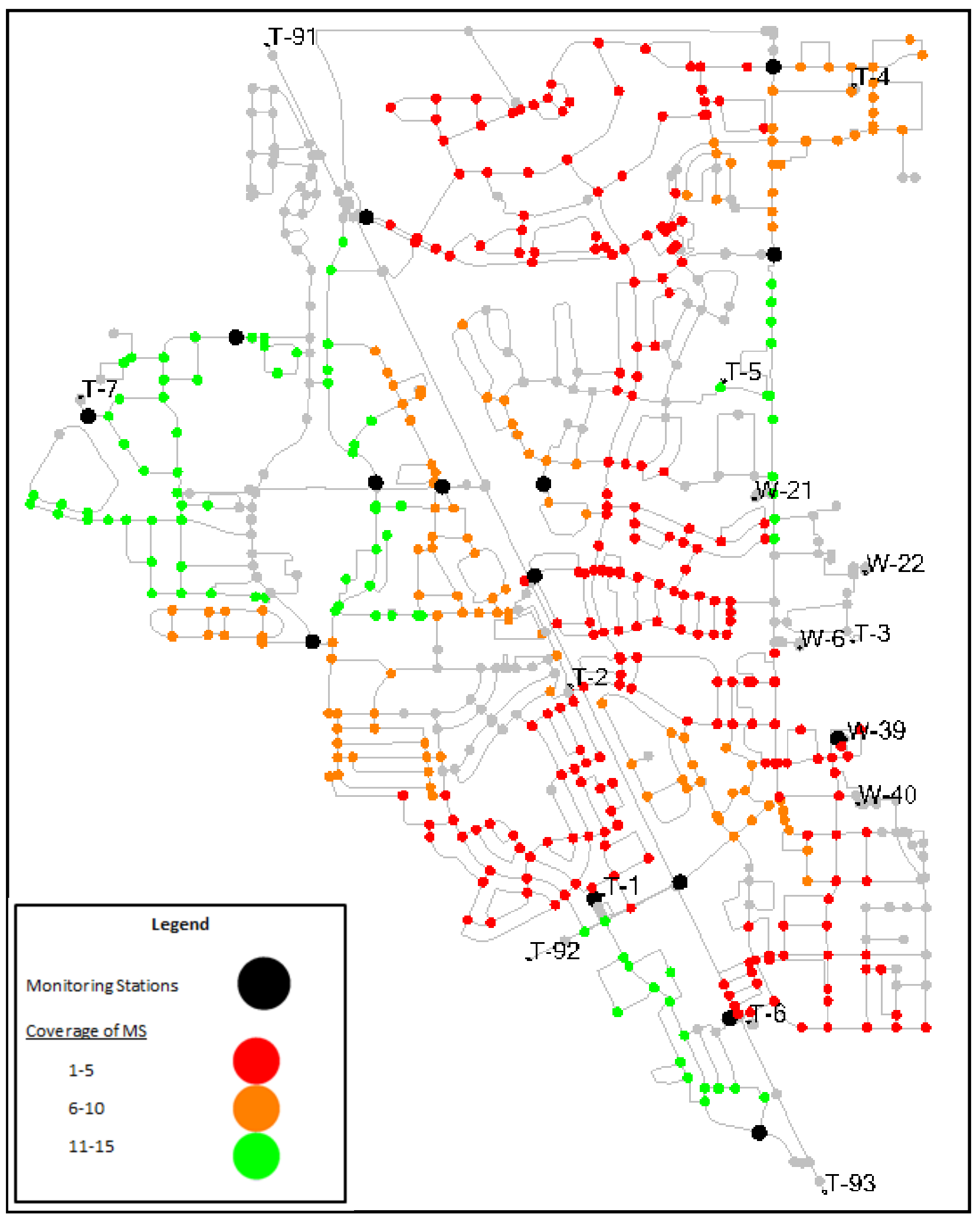

Figure 58: Top 15 Monitoring Stations with Corresponding Coverages for Demand Pattern 5.0 (Unsteady State) 


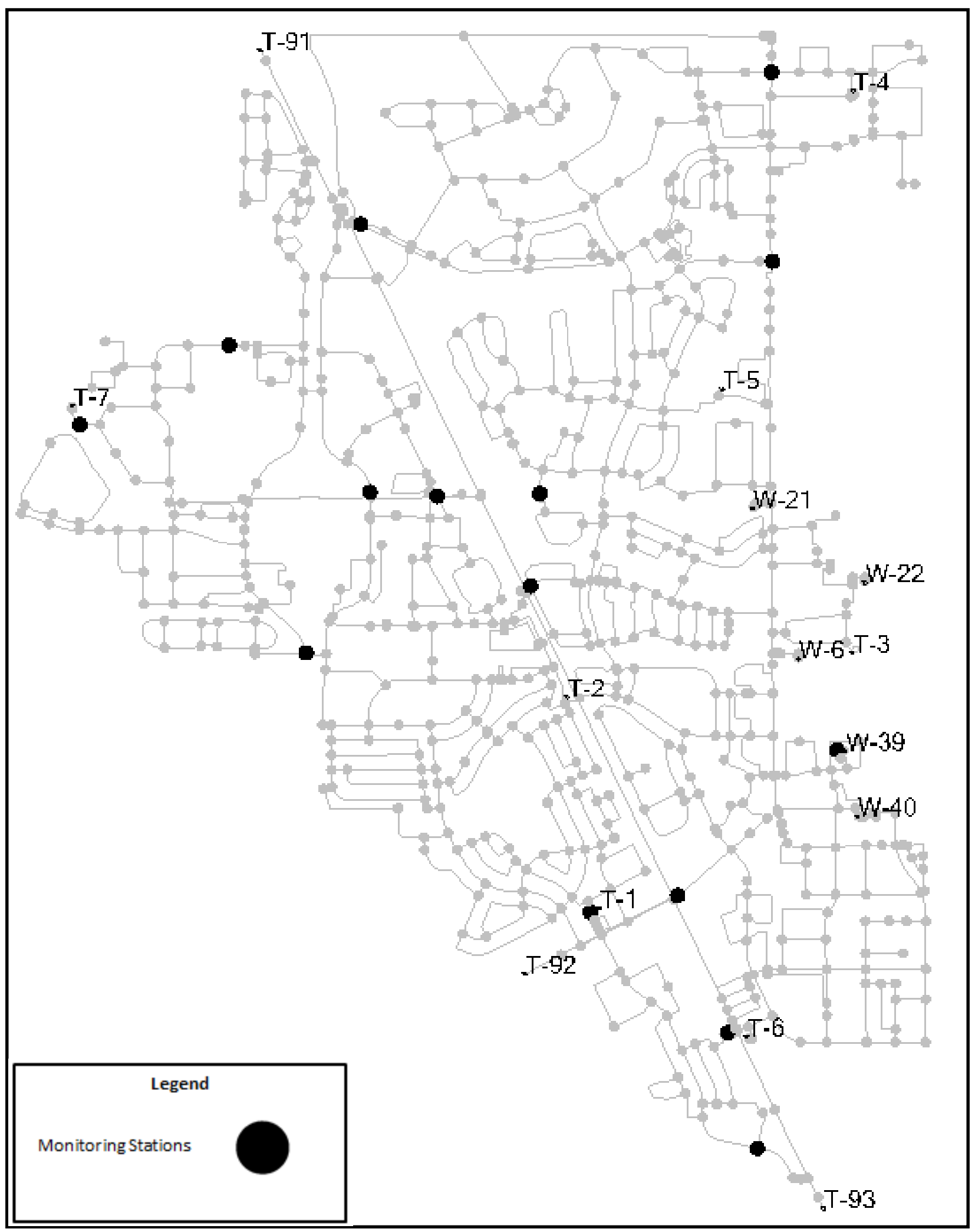

Figure 59: Top 15 Monitoring Stations for Demand Pattern 5.0 (Unsteady State) 


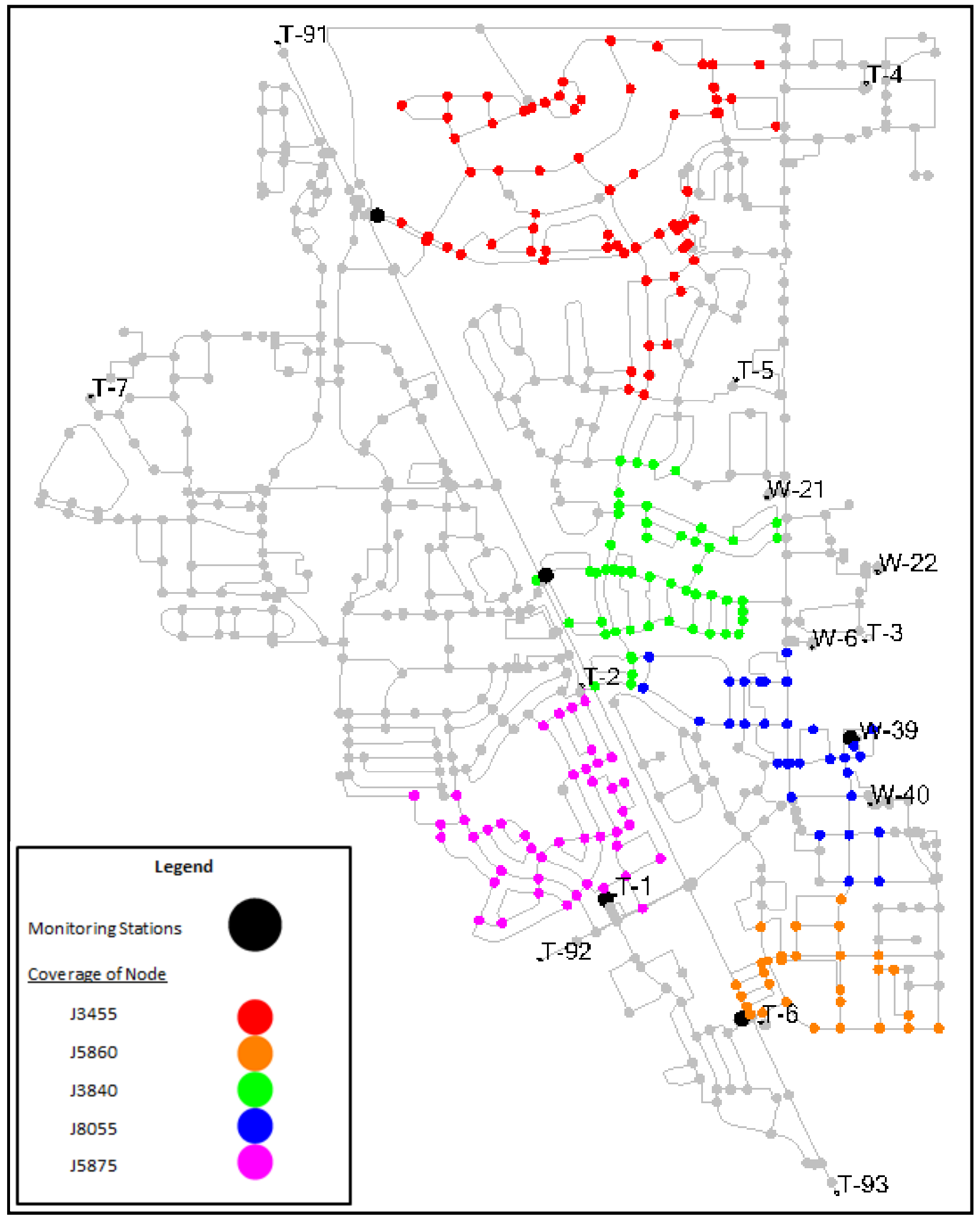

Figure 60: Monitoring Station 1-5 with Corresponding Coverages for Demand Pattern 6.0 (Unsteady State) 


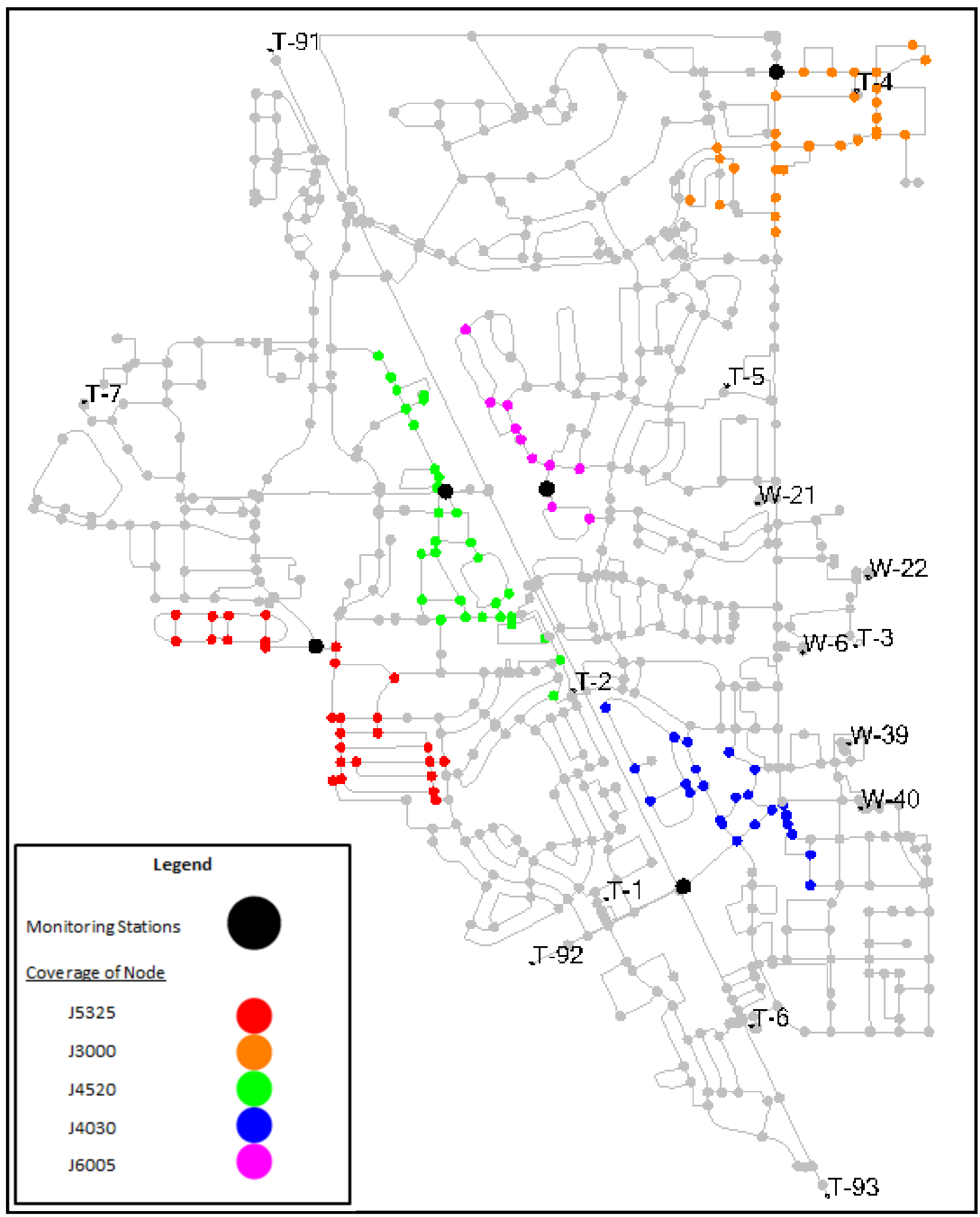

Figure 61: Monitoring Station 6-10 with Corresponding Coverages for Demand Pattern 6.0 (Unsteady State) 


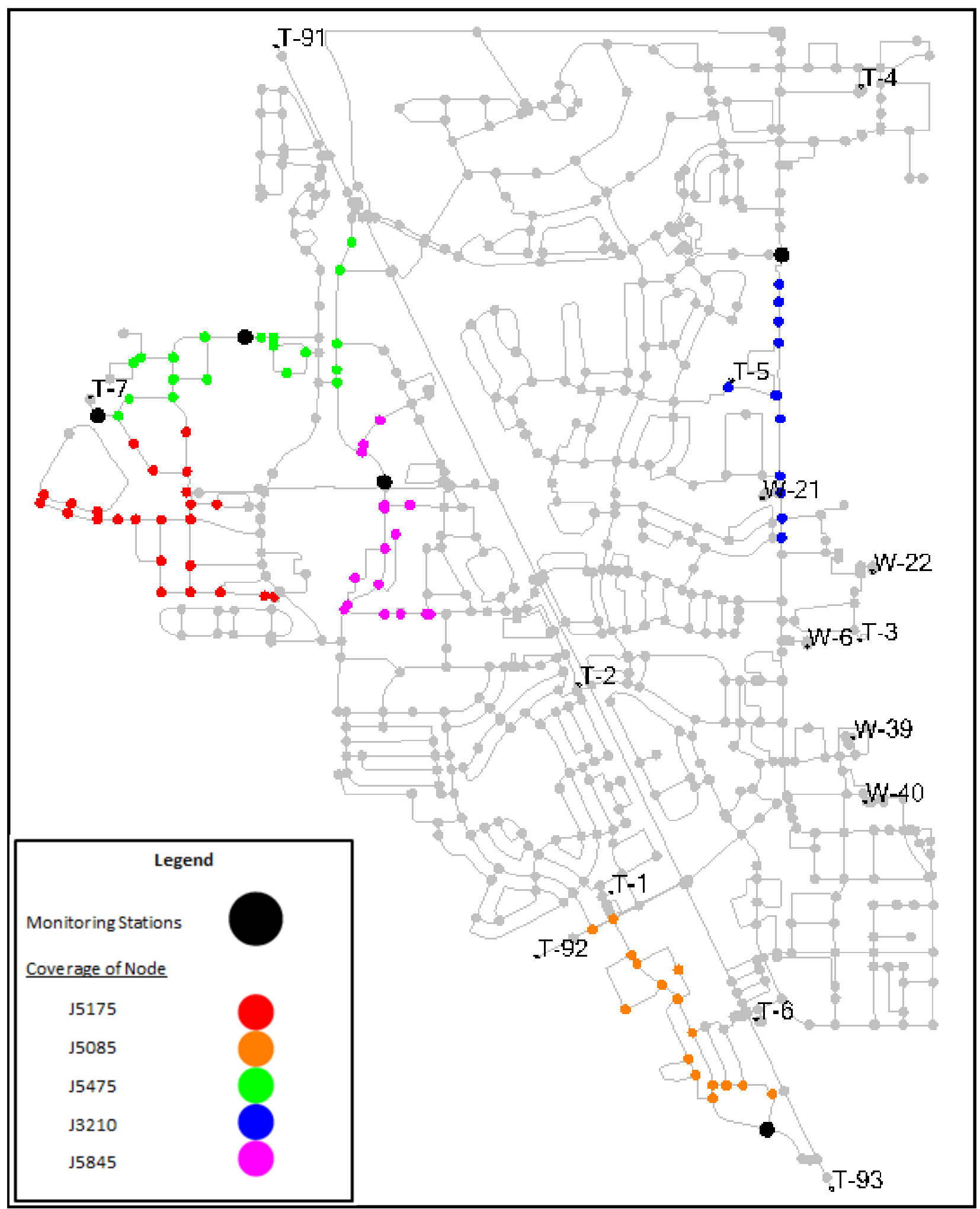

Figure 62: Monitoring Station 11-15 with Corresponding Coverages for Demand Pattern 6.0 (Unsteady State) 


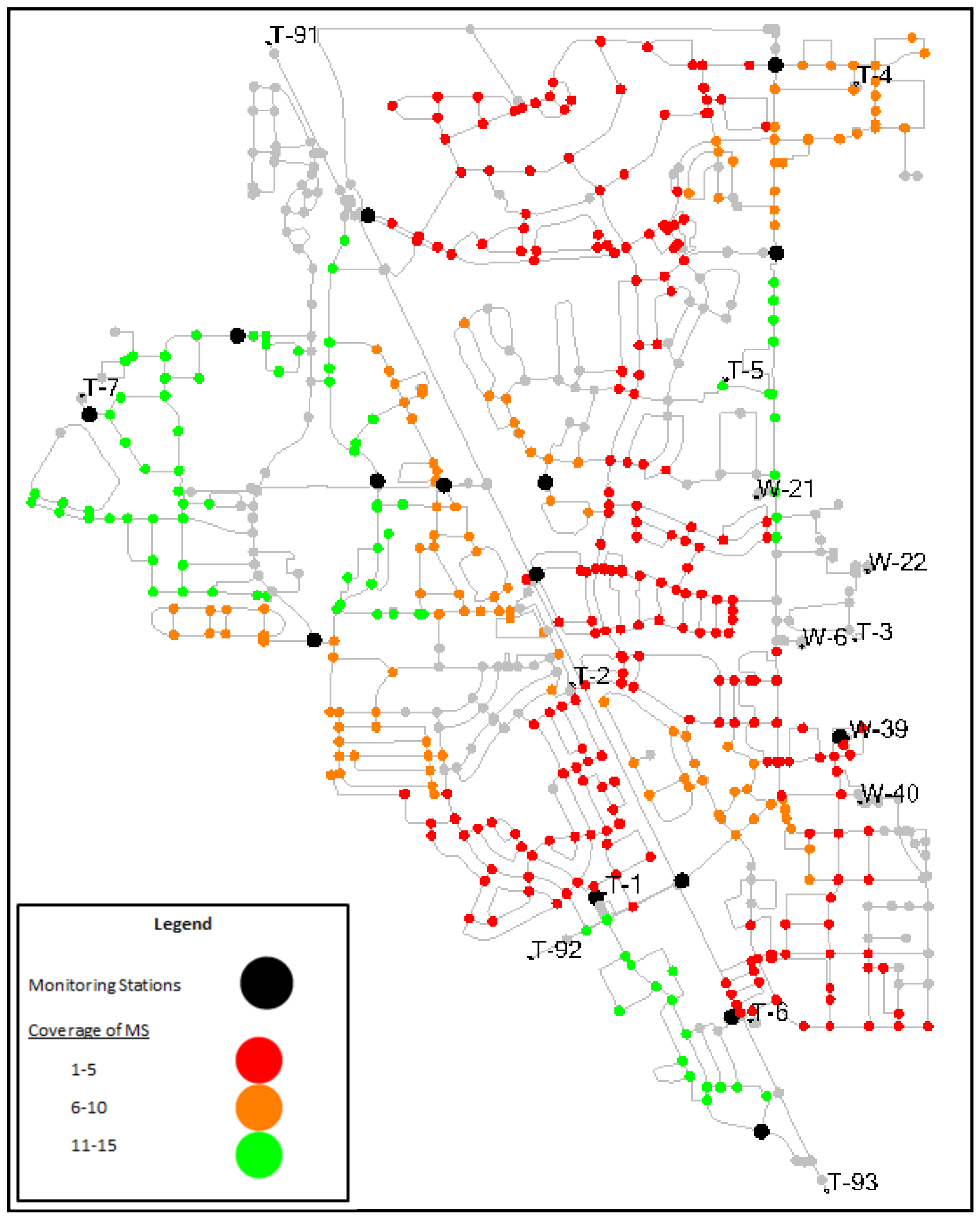

Figure 63: Top 15 Monitoring Stations with Corresponding Coverages for Demand Pattern 6.0 (Unsteady State) 


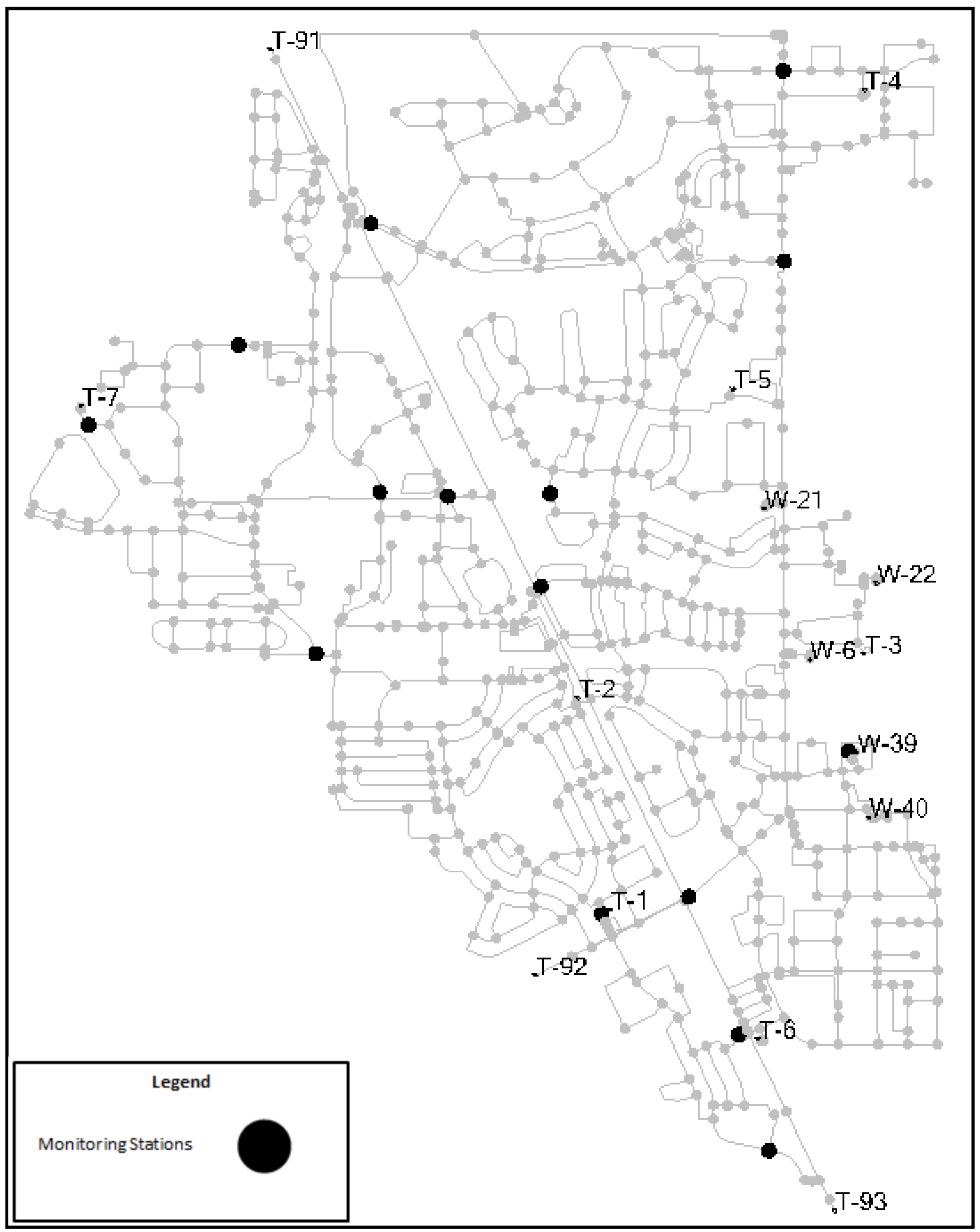

Figure 64: Top 15 Monitoring Stations for Demand Pattern 6.0 (Unsteady State) 


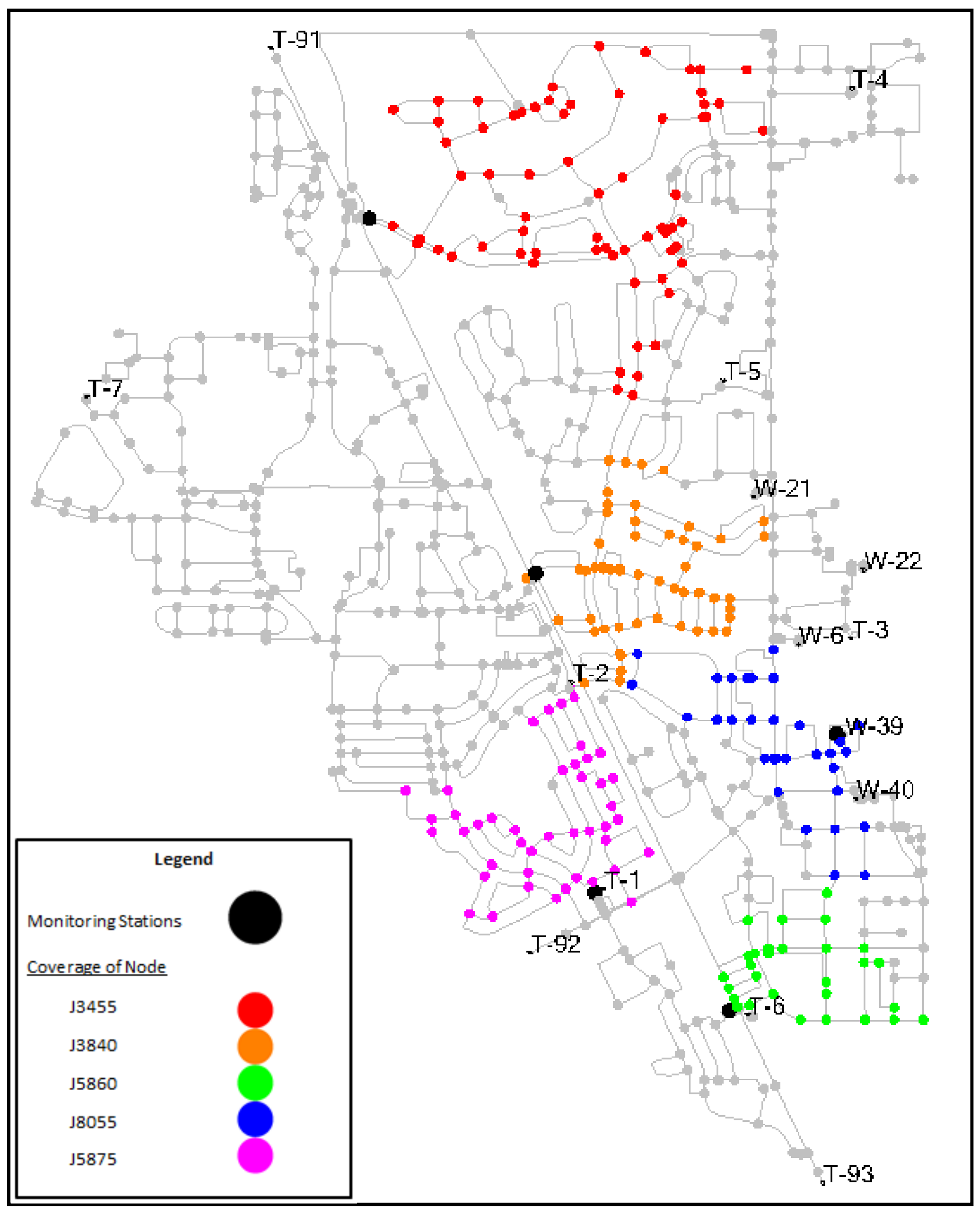

Figure 65: Monitoring Station 1-5 with Corresponding Coverages for Demand Pattern 7.0 (Unsteady State) 


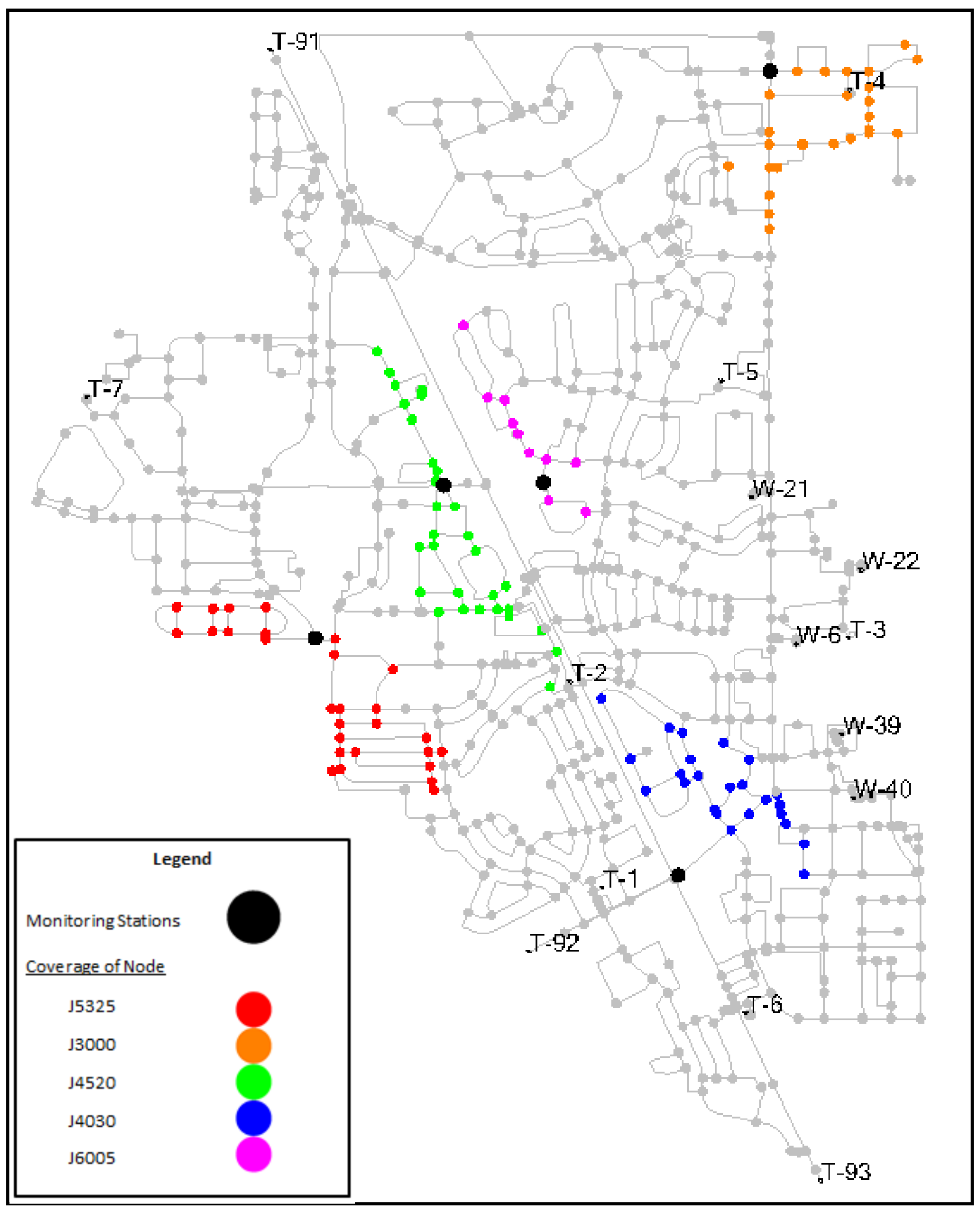

Figure 66: Monitoring Station 6-10 with Corresponding Coverages for Demand Pattern 7.0 (Unsteady State) 


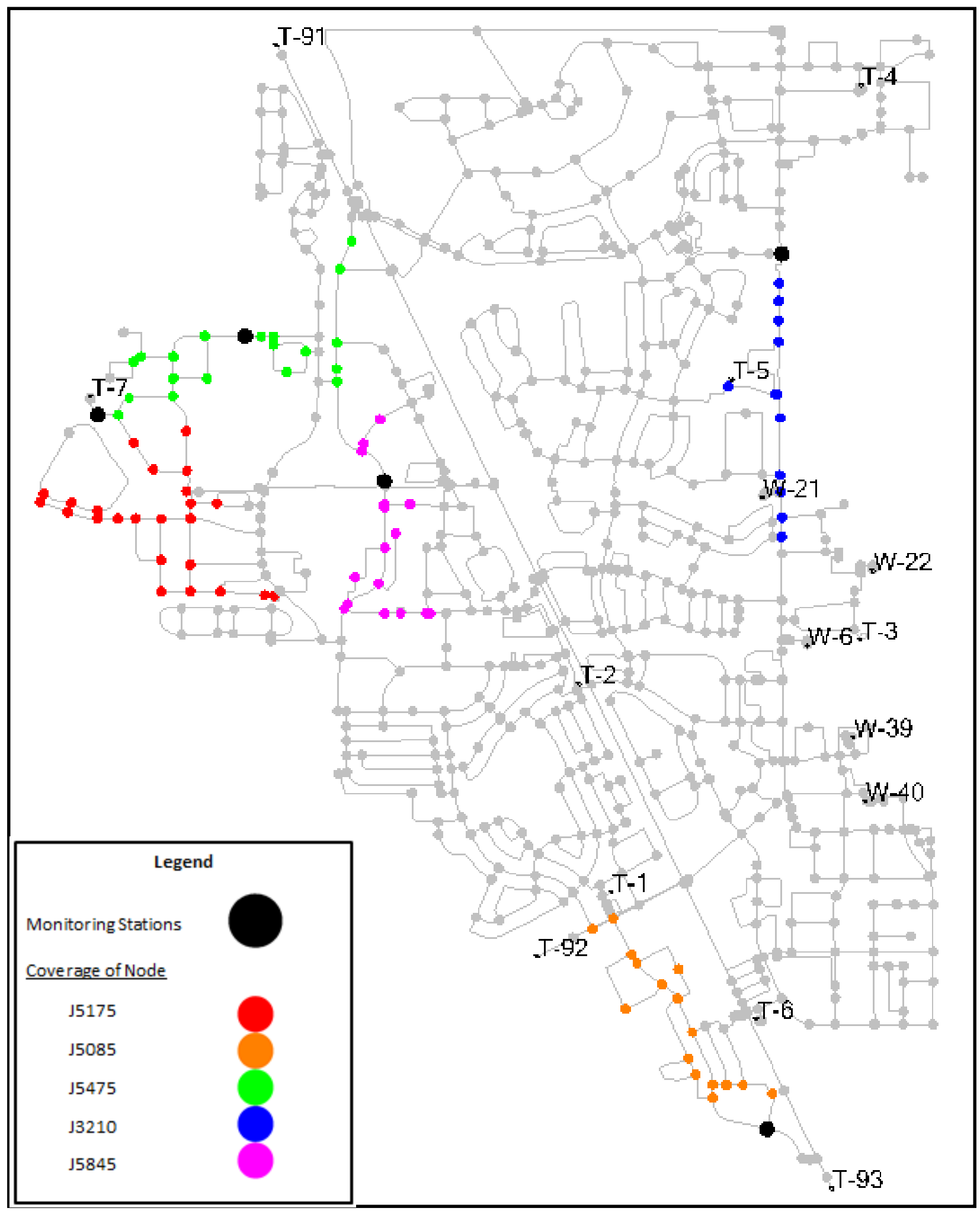

Figure 67: Monitoring Station 11-15 with Corresponding Coverages for Demand Pattern 7.0 (Unsteady State) 


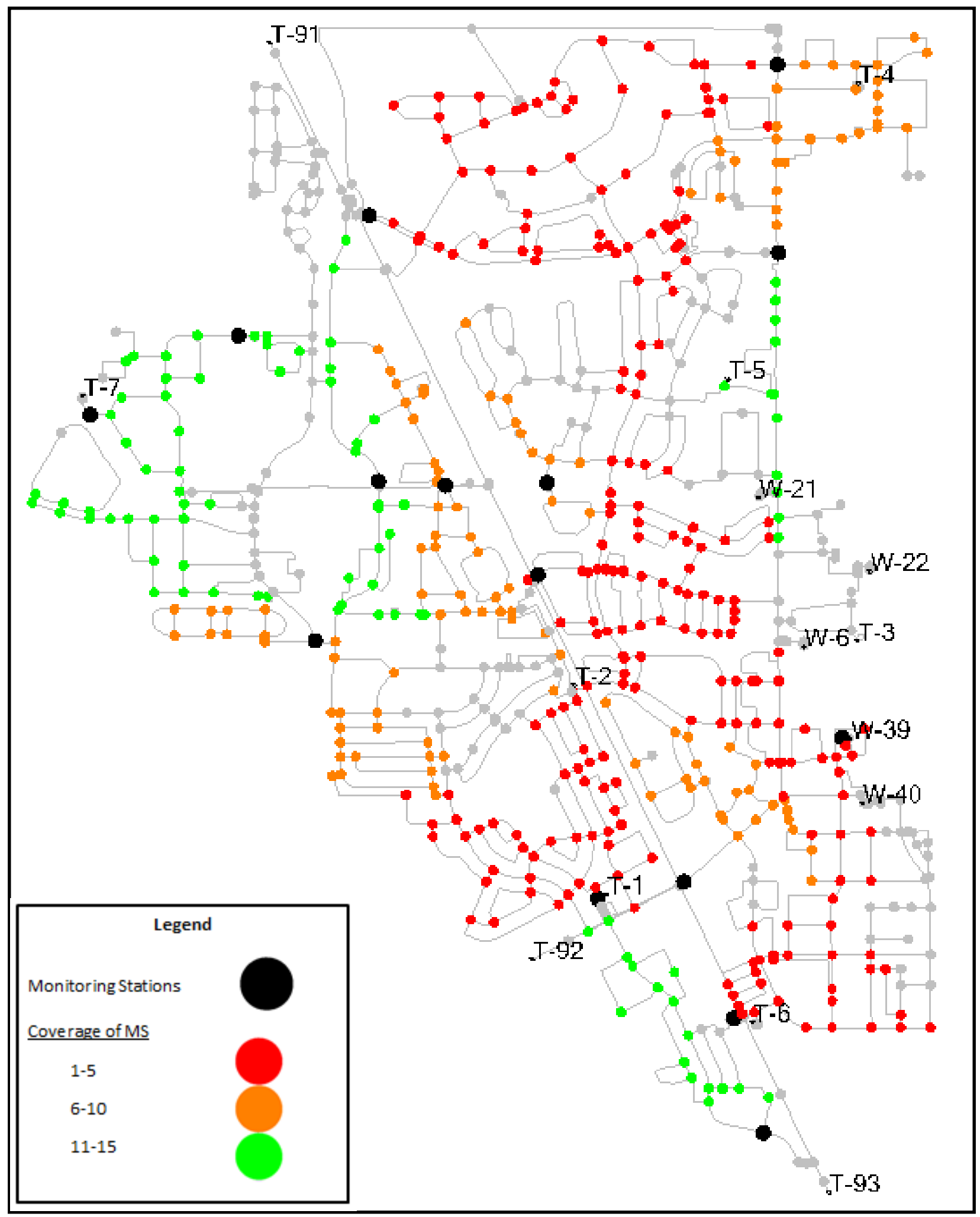

Figure 68: Top 15 Monitoring Stations with Corresponding Coverages for Demand Pattern 7.0 (Unsteady State) 


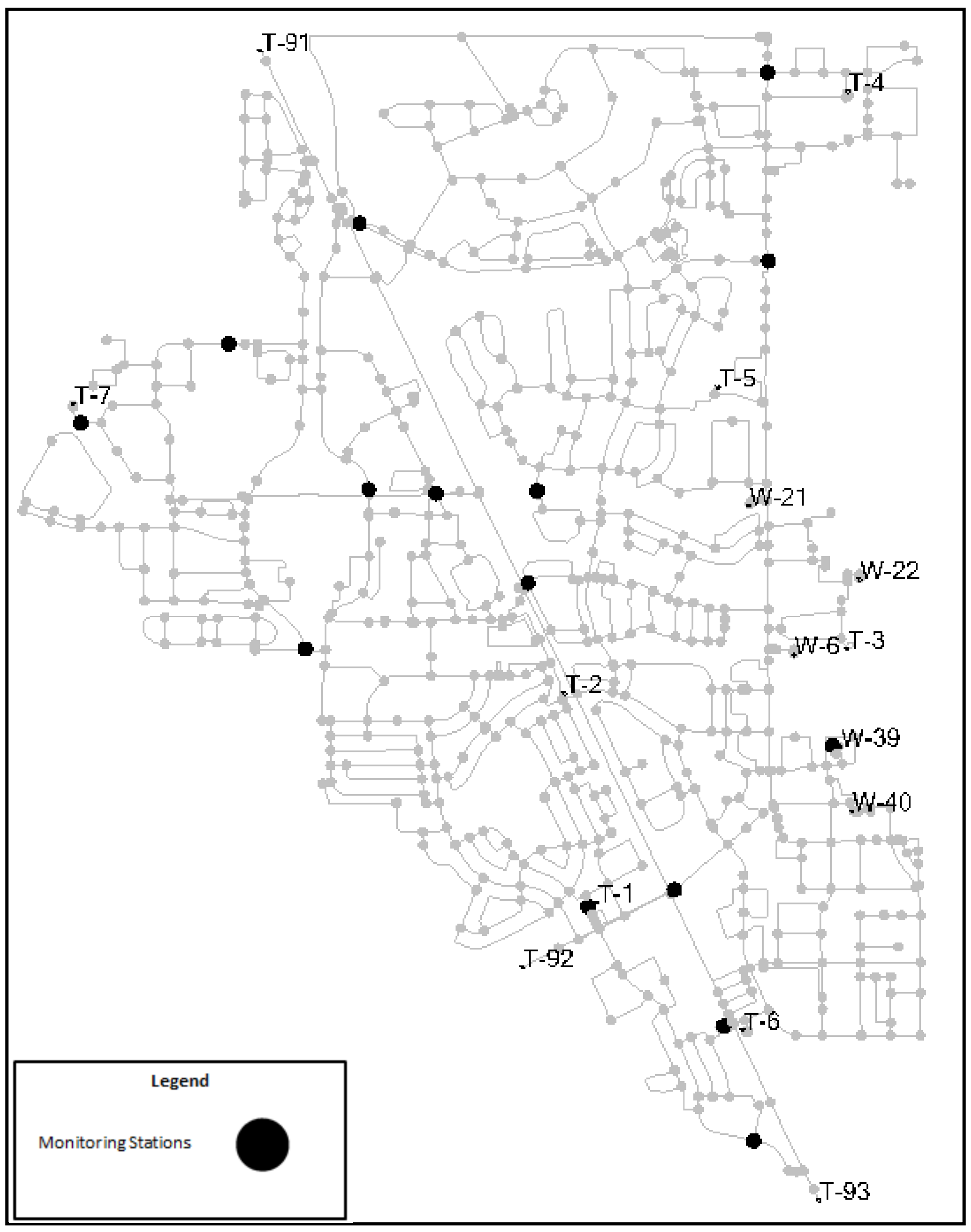

Figure 69: Top 15 Monitoring Stations for Demand Pattern 7.0 (Unsteady State) 


\section{APPENDIX B}

The contents of Appendix B contain a list compiled by the Environmental Protection Agency of contaminants, including microorganisms, disinfection byproducts, disinfectants, inorganic chemicals, organic chemicals, and radionuclides. 


\begin{tabular}{|c|c|c|c|c|}
\hline \multicolumn{5}{|l|}{ Microorganisms } \\
\hline Contaminant & $\begin{array}{l}\mathrm{MCLG}^{1} \\
(\mathrm{MG} / \mathrm{L})^{2}\end{array}$ & $\begin{array}{l}\text { MCL } \\
\text { or } \mathrm{TT}^{2} \\
(\mathrm{MC} / \mathrm{L})^{2}\end{array}$ & $\begin{array}{l}\text { Potential Health Effects from Long-Term Exposure Above } \\
\text { the MCL (unless specified as short-term) }\end{array}$ & $\begin{array}{l}\text { Sources of } \\
\text { Contaminant in } \\
\text { Drinking Water }\end{array}$ \\
\hline Cryptosporidium & zero & $\mathrm{TT}^{3}$ & $\begin{array}{l}\text { Gastrointestinal illness (such as diarrhea, vomiting, and } \\
\text { cramps) }\end{array}$ & $\begin{array}{l}\text { Human and animal } \\
\text { fecal waste }\end{array}$ \\
\hline Giardia lamblia & zero & $\mathrm{TT}^{3}$ & $\begin{array}{l}\text { Gastrointestinal illness (such as diarrhea, vomiting, and } \\
\text { cramps) }\end{array}$ & $\begin{array}{l}\text { Human and animal } \\
\text { fecal waste }\end{array}$ \\
\hline $\begin{array}{l}\text { Heterotrophic } \\
\text { plate count } \\
\text { (HPC) }\end{array}$ & $\mathrm{n} / \mathrm{a}$ & $\mathrm{TT}^{3}$ & $\begin{array}{l}\text { HPC has no health effects; it is an analytic method used to } \\
\text { measure the variety of bacteria that are common in water. } \\
\text { The lower the concentration of bacteria in drinking water, the } \\
\text { better maintained the water system is. }\end{array}$ & $\begin{array}{l}\text { HPC measures a } \\
\text { range of bacteria } \\
\text { that are naturally } \\
\text { present in the } \\
\text { environment }\end{array}$ \\
\hline Legionella & zero & $\mathrm{TT}^{3}$ & Legionnaire's Disease, a type of pneumonia & $\begin{array}{l}\text { Found naturally in } \\
\text { water; multiplies in } \\
\text { heating systems }\end{array}$ \\
\hline $\begin{array}{l}\text { Total Coliforms } \\
\text { (including fecal } \\
\text { coliform and } E \text {. } \\
\text { Coli) }\end{array}$ & zero & $5.0 \%{ }^{4}$ & $\begin{array}{l}\text { Not a health threat in itself; it is used to indicate whether } \\
\text { other potentially harmful bacteria may be present }\end{array}$ & $\begin{array}{l}\text { Coliforms are } \\
\text { naturally present in } \\
\text { the environment; as } \\
\text { well as feces; fecal } \\
\text { coliforms and } E \text {. } \\
\text { colionly come from } \\
\text { human and animal } \\
\text { fecal waste. }\end{array}$ \\
\hline Turbidity & $n / a$ & $\mathrm{TT}^{3}$ & $\begin{array}{l}\text { Turbidity is a measure of the cloudiness of water. It is used } \\
\text { to indicate water quality and filtration effectiveness (such as } \\
\text { whether disease-causing organisms are present). Higher } \\
\text { turbidity levels are often associated with higher levels of } \\
\text { disease-causing microorganisms such as viruses, parasites } \\
\text { and some bacteria. These organisms can cause symptoms } \\
\text { such as nausea, cramps, diarrhea, and associated headaches. }\end{array}$ & Soil runoff \\
\hline Viruses (enteric) & zero & $\mathrm{TT}^{3}$ & $\begin{array}{l}\text { Gastrointestinal illness (such as diarrhea, vomiting, and } \\
\text { cramps) }\end{array}$ & $\begin{array}{l}\text { Human and animal } \\
\text { fecal waste }\end{array}$ \\
\hline
\end{tabular}




\begin{tabular}{|c|c|c|c|c|c|}
\hline \multicolumn{6}{|c|}{ Disinfection Byproducts } \\
\hline Contaminant & $\begin{array}{l}\mathrm{MCLG}^{1} \\
(\mathrm{MG} / \mathrm{L})^{2}\end{array}$ & $\begin{array}{l}\text { MCL or } \\
\mathrm{TT}^{1} \\
(\mathrm{MG} / \mathrm{L})^{2}\end{array}$ & \multicolumn{2}{|c|}{$\begin{array}{l}\text { Potential Health Effects from Long-Term Exposure } \\
\text { Above the MCL (unless specified as short-term) }\end{array}$} & $\begin{array}{l}\text { Sources of } \\
\text { Contaminant in } \\
\text { Drinking Water }\end{array}$ \\
\hline Bromate & zero & 0.010 & \multicolumn{2}{|c|}{ Increased risk of cancer } & $\begin{array}{l}\text { Byproduct of drinking } \\
\text { water disinfection }\end{array}$ \\
\hline Chlorite & 0.8 & 1.0 & \multicolumn{2}{|c|}{$\begin{array}{l}\text { Anemia; infants and young children: nervous system } \\
\text { effects }\end{array}$} & $\begin{array}{l}\text { Byproduct of drinking } \\
\text { water disinfection }\end{array}$ \\
\hline $\begin{array}{l}\text { Haloacetic acids } \\
\text { (HAA5) }\end{array}$ & $\mathrm{n} / \mathrm{a}^{6}$ & $0.060^{7}$ & \multicolumn{2}{|c|}{ Increased risk of cancer } & $\begin{array}{l}\text { Byproduct of drinking } \\
\text { water disinfection }\end{array}$ \\
\hline $\begin{array}{l}\text { Total } \\
\text { Trihalomethanes } \\
\text { (TTHMs) }\end{array}$ & $n / a^{6}$ & $-->7$ & \multicolumn{2}{|c|}{$\begin{array}{l}\text { Liver, kidney or central nervous system problems; } \\
\text { increased risk of cancer }\end{array}$} & $\begin{array}{l}\text { Byproduct of drinking } \\
\text { water disinfection }\end{array}$ \\
\hline \multicolumn{6}{|l|}{ 仓̂Top of page } \\
\hline \multicolumn{6}{|l|}{ Disinfectants } \\
\hline Contaminant & \multicolumn{2}{|c|}{$\begin{array}{l}\mathrm{MCLG}_{2}^{1} \\
(\mathrm{MG} / \mathrm{L})^{2}\end{array}$} & $\begin{array}{l}\text { MCL or } T^{1} \\
(\mathrm{MG} / \mathrm{L})^{2}\end{array}$ & $\begin{array}{l}\text { Potential Health Effects from Long-Term } \\
\text { Exposure Above the MCL (unless specified as } \\
\text { short-term) }\end{array}$ & $\begin{array}{l}\text { Sources of } \\
\text { Contaminant in } \\
\text { Drinking Water }\end{array}$ \\
\hline $\begin{array}{l}\text { Chloramines (as } \\
\mathrm{CL}_{2} \text { ) }\end{array}$ & \multicolumn{2}{|c|}{ MRDLG $=4^{1}$} & MRDL $=4.0^{1}$ & $\begin{array}{l}\text { Eye/nose irritation; stomach discomfort, } \\
\text { anemia }\end{array}$ & $\begin{array}{l}\text { Water additive used to } \\
\text { control microbes }\end{array}$ \\
\hline Chlorine (as $\mathrm{CL}_{2}$ ) & \multicolumn{2}{|c|}{ MRDLG $=4^{1}$} & MRDL $=4.0^{1}$ & Eye/nose irritation; stomach discomfort & $\begin{array}{l}\text { Water additive used to } \\
\text { control microbes }\end{array}$ \\
\hline $\begin{array}{l}\text { Chlorine dioxide } \\
\text { (as } \mathrm{CLO}_{2} \text { ) }\end{array}$ & \multicolumn{2}{|c|}{ MRDLG $=0.8^{1}$} & $\mathrm{MRDL}=0.8^{1}$ & $\begin{array}{l}\text { Anemia; infants and young children: nervous } \\
\text { system effects }\end{array}$ & $\begin{array}{l}\text { Water additive used to } \\
\text { control microbes }\end{array}$ \\
\hline
\end{tabular}




\begin{tabular}{|c|c|c|c|c|}
\hline \multicolumn{5}{|c|}{ Inorganic Chemicals } \\
\hline Contaminant & $\begin{array}{l}\mathrm{MCLG}_{2}^{1} \\
(\mathrm{MG} / \mathrm{L})^{2}\end{array}$ & $\begin{array}{l}\text { MCL or } T^{1} \\
(\mathrm{MG} / \mathrm{L})^{2}\end{array}$ & $\begin{array}{l}\text { Potential Health Effects from Long-Term } \\
\text { Exposure Above the MCL (unless specified as } \\
\text { short-term) }\end{array}$ & $\begin{array}{l}\text { Sources of } \\
\text { Contaminant in } \\
\text { Drinking Water }\end{array}$ \\
\hline Antimony & 0.006 & 0.006 & $\begin{array}{l}\text { Increase in blood cholesterol; decrease in blood } \\
\text { sugar }\end{array}$ & $\begin{array}{l}\text { Discharge from } \\
\text { petroleum refineries; } \\
\text { fire retardants; } \\
\text { ceramics; electronics; } \\
\text { solder }\end{array}$ \\
\hline Arsenic & 0 & $\begin{array}{l}0.010 \text { as of } \\
01 / 23 / 06\end{array}$ & $\begin{array}{l}\text { Skin damage or problems with circulatory } \\
\text { systems, and may have increased risk of getting } \\
\text { cancer }\end{array}$ & $\begin{array}{l}\text { Erosion of natural } \\
\text { deposits; runoff from } \\
\text { orchards, runoff from } \\
\text { glass and } \\
\text { electronicsproduction } \\
\text { wastes }\end{array}$ \\
\hline $\begin{array}{l}\text { Asbestos (fiber } \\
>10 \\
\text { micrometers) }\end{array}$ & $\begin{array}{l}7 \text { million } \\
\text { fibers per } \\
\text { liter (MFL) }\end{array}$ & $7 \mathrm{MFL}$ & $\begin{array}{l}\text { Increased risk of developing benign intestinal } \\
\text { polyps }\end{array}$ & $\begin{array}{l}\text { Decay of asbestos } \\
\text { cement in water mains; } \\
\text { erosion of natural } \\
\text { deposits }\end{array}$ \\
\hline Barium & 2 & 2 & Increase in blood pressure & $\begin{array}{l}\text { Discharge of drilling } \\
\text { wastes; discharge from } \\
\text { metal refineries; } \\
\text { erosion of natural } \\
\text { deposits }\end{array}$ \\
\hline Beryllium & 0.004 & 0.004 & Intestinal lesions & $\begin{array}{l}\text { Discharge from metal } \\
\text { refineries and coal- } \\
\text { burning factories; } \\
\text { discharge from } \\
\text { electrical, aerospace, } \\
\text { and defense industries }\end{array}$ \\
\hline Cadmium & 0.005 & 0.005 & Kidney damage & $\begin{array}{l}\text { Corrosion of } \\
\text { galvanized pipes; } \\
\text { erosion of natural } \\
\text { deposits; discharge } \\
\text { from metal refineries; } \\
\text { runoff from waste } \\
\text { batteries and paints }\end{array}$ \\
\hline
\end{tabular}




\begin{tabular}{|c|c|c|c|c|}
\hline $\begin{array}{l}\text { Chromium } \\
\text { (total) }\end{array}$ & 0.1 & 0.1 & Allergic dermatitis & $\begin{array}{l}\text { Discharge from steel } \\
\text { and pulp mills; erosion } \\
\text { of natural deposits }\end{array}$ \\
\hline Copper & 1.3 & $\begin{array}{l}\mathrm{TT}^{7} ; \text { Action } \\
\text { Level }=1.3\end{array}$ & $\begin{array}{l}\text { Short term exposure: Gastrointestinal distress } \\
\text { Long term exposure: Liver or kidney damage } \\
\text { People with Wilson's Disease should consult their } \\
\text { personal doctor if the amount of copper in their } \\
\text { water exceeds the action level }\end{array}$ & $\begin{array}{l}\text { Corrosion of household } \\
\text { plumbing systems; } \\
\text { erosion of natural } \\
\text { deposits }\end{array}$ \\
\hline $\begin{array}{l}\text { Cyanide (as free } \\
\text { cyanide) }\end{array}$ & 0.2 & 0.2 & Nerve damage or thyroid problems & $\begin{array}{l}\text { Discharge from } \\
\text { steel/metal factories; } \\
\text { discharge from plastic } \\
\text { and fertilizer factories }\end{array}$ \\
\hline Fluoride & 4.0 & 4.0 & $\begin{array}{l}\text { Bone disease (pain and tenderness of the bones); } \\
\text { Children may get mottled teeth }\end{array}$ & $\begin{array}{l}\text { Water additive which } \\
\text { promotes strong teeth; } \\
\text { erosion of natural } \\
\text { deposits; discharge } \\
\text { from fertilizer and } \\
\text { aluminum factories }\end{array}$ \\
\hline Lead & zero & $\begin{array}{l}\mathrm{TT}^{7} ; \text { Action } \\
\text { Level }=0.015\end{array}$ & $\begin{array}{l}\text { Infants and children: Delays in physical or mental } \\
\text { development; children could show slight deficits } \\
\text { in attention span and learning abilities } \\
\text { Adults: Kidney problems; high blood pressure }\end{array}$ & $\begin{array}{l}\text { Corrosion of household } \\
\text { plumbing systems; } \\
\text { erosion of natural } \\
\text { deposits }\end{array}$ \\
\hline $\begin{array}{l}\text { Mercury } \\
\text { (inorganic) }\end{array}$ & 0.002 & 0.002 & Kidney damage & $\begin{array}{l}\text { Erosion of natural } \\
\text { deposits; discharge } \\
\text { from refineries and } \\
\text { factories; runoff from } \\
\text { landfills and croplands }\end{array}$ \\
\hline $\begin{array}{l}\text { Nitrate } \\
\text { (measured as } \\
\text { Nitrogen) }\end{array}$ & 10 & 10 & $\begin{array}{l}\text { Infants below the age of six months who drink } \\
\text { water containing nitrate in excess of the } \mathrm{MCL} \\
\text { could become seriously ill and, if untreated, may } \\
\text { die. Symptoms include shortness of breath and } \\
\text { blue-baby syndrome. }\end{array}$ & $\begin{array}{l}\text { Runoff from fertilizer } \\
\text { use; leaking from } \\
\text { septic tanks, sewage; } \\
\text { erosion of natural } \\
\text { deposits }\end{array}$ \\
\hline
\end{tabular}




\begin{tabular}{|c|c|c|c|c|}
\hline $\begin{array}{l}\text { Nitrite } \\
\text { (measured as } \\
\text { Nitrogen) }\end{array}$ & 1 & 1 & $\begin{array}{l}\text { Infants below the age of six months who drink } \\
\text { water containing nitrite in excess of the } \mathrm{MCL} \\
\text { could become seriously ill and, if untreated, may } \\
\text { die. Symptoms include shortness of breath and } \\
\text { blue-baby syndrome. }\end{array}$ & $\begin{array}{l}\text { Runoff from fertilizer } \\
\text { use; leaking from } \\
\text { septic tanks, sewage; } \\
\text { erosion of natural } \\
\text { deposits }\end{array}$ \\
\hline Selenium & 0.05 & 0.05 & $\begin{array}{l}\text { Hair or fingernail loss; numbness in fingers or } \\
\text { toes; circulatory problems }\end{array}$ & $\begin{array}{l}\text { Discharge from } \\
\text { petroleum refineries; } \\
\text { erosion of natural } \\
\text { deposits; discharge } \\
\text { from mines }\end{array}$ \\
\hline Thallium & 0.0005 & 0.002 & $\begin{array}{l}\text { Hair loss; changes in blood; kidney, intestine, or } \\
\text { liver problems }\end{array}$ & $\begin{array}{l}\text { Leaching from ore- } \\
\text { processing sites; } \\
\text { discharge from } \\
\text { electronics, glass, and } \\
\text { drug factories }\end{array}$ \\
\hline
\end{tabular}




\begin{tabular}{|c|c|c|c|c|}
\hline \multicolumn{5}{|l|}{ Organic Chemicals } \\
\hline Contaminant & ${ }_{(\mathrm{MC} / \mathrm{L})^{2}}^{\mathrm{MCLG}^{1}}$ & $\begin{array}{l}\mathrm{MCL} \text { or } \mathrm{TT}^{1} \\
(\mathrm{MG} / \mathrm{L})^{2}\end{array}$ & $\begin{array}{l}\text { Potential Health Effects from Long- } \\
\text { Term Exposure Above the MCL } \\
\text { (unless specified as short-term) }\end{array}$ & $\begin{array}{l}\text { Sources of Contaminant in } \\
\text { Drinking Water }\end{array}$ \\
\hline Acrylamide & zero & $\mathrm{TT}^{8}$ & $\begin{array}{l}\text { Nervous system or blood problems; } \\
\text { increased risk of cancer }\end{array}$ & $\begin{array}{l}\text { Added to water during } \\
\text { sewage/wastewater } \\
\text { treatment }\end{array}$ \\
\hline Alachlor & zero & 0.002 & $\begin{array}{l}\text { Eye, liver, kidney or spleen problems; } \\
\text { anemia; increased risk of cancer }\end{array}$ & $\begin{array}{l}\text { Runoff from herbicide used } \\
\text { on row crops }\end{array}$ \\
\hline Atrazine & 0.003 & 0.003 & $\begin{array}{l}\text { Cardiovascular system or reproductive } \\
\text { problems }\end{array}$ & $\begin{array}{l}\text { Runoff from herbicide used } \\
\text { on row crops }\end{array}$ \\
\hline Benzene & zero & 0.005 & $\begin{array}{l}\text { Anemia; decrease in blood platelets; } \\
\text { increased risk of cancer }\end{array}$ & $\begin{array}{l}\text { Discharge from factories; } \\
\text { leaching from gas storage } \\
\text { tanks and landfills }\end{array}$ \\
\hline Benzo(a)pyrene (PAHs) & zero & 0.0002 & $\begin{array}{l}\text { Reproductive difficulties; increased } \\
\text { risk of cancer }\end{array}$ & $\begin{array}{l}\text { Leaching from linings of } \\
\text { water storage tanks and } \\
\text { distribution lines }\end{array}$ \\
\hline Carbofuran & 0.04 & 0.04 & $\begin{array}{l}\text { Problems with blood, nervous system, } \\
\text { or reproductive system }\end{array}$ & $\begin{array}{l}\text { Leaching of soil fumigant } \\
\text { used on rice and alfalfa }\end{array}$ \\
\hline Carbon tetrachloride & zero & 0.005 & $\begin{array}{l}\text { Liver problems; increased risk of } \\
\text { cancer }\end{array}$ & $\begin{array}{l}\text { Discharge from chemical } \\
\text { plants and other industrial } \\
\text { activities }\end{array}$ \\
\hline Chlordane & zero & 0.002 & $\begin{array}{l}\text { Liver or nervous system problems; } \\
\text { increased risk of cancer }\end{array}$ & $\begin{array}{l}\text { Residue of banned } \\
\text { termiticide }\end{array}$ \\
\hline Chlorobenzene & 0.1 & 0.1 & Liver or kidney problems & $\begin{array}{l}\text { Discharge from chemical } \\
\text { and agricultural chemical } \\
\text { factories }\end{array}$ \\
\hline $2,4-D$ & 0.07 & 0.07 & $\begin{array}{l}\text { Kidney, liver, or adrenal gland } \\
\text { problems }\end{array}$ & $\begin{array}{l}\text { Runoff from herbicide used } \\
\text { on row crops }\end{array}$ \\
\hline Dalapon & 0.2 & 0.2 & Minor kidney changes & $\begin{array}{l}\text { Runoff from herbicide used } \\
\text { on rights of way }\end{array}$ \\
\hline
\end{tabular}




\begin{tabular}{|c|c|c|c|c|}
\hline $\begin{array}{l}\text { 1,2-Dibromo-3- } \\
\text { chloropropane (DBCP) }\end{array}$ & zero & 0.0002 & $\begin{array}{l}\text { Reproductive difficulties; increased } \\
\text { risk of cancer }\end{array}$ & $\begin{array}{l}\text { Runoff/leaching from soil } \\
\text { fumigant used on } \\
\text { soybeans, cotton, } \\
\text { pineapples, and orchards }\end{array}$ \\
\hline o-Dichlorobenzene & 0.6 & 0.6 & $\begin{array}{l}\text { Liver, kidney, or circulatory system } \\
\text { problems }\end{array}$ & $\begin{array}{l}\text { Discharge from industrial } \\
\text { chemical factories }\end{array}$ \\
\hline p-Dichlorobenzene & 0.075 & 0.075 & $\begin{array}{l}\text { Anemia; liver, kidney or spleen } \\
\text { damage; changes in blood }\end{array}$ & $\begin{array}{l}\text { Discharge from industrial } \\
\text { chemical factories }\end{array}$ \\
\hline 1,2-Dichloroethane & zero & 0.005 & Increased risk of cancer & $\begin{array}{l}\text { Discharge from industrial } \\
\text { chemical factories }\end{array}$ \\
\hline 1,1-Dichloroethylene & 0.007 & 0.007 & Liver problems & $\begin{array}{l}\text { Discharge from industrial } \\
\text { chemical factories }\end{array}$ \\
\hline cis-1,2-Dichloroethylene & 0.07 & 0.07 & Liver problems & $\begin{array}{l}\text { Discharge from industrial } \\
\text { chemical factories }\end{array}$ \\
\hline $\begin{array}{l}\text { trans-1,2- } \\
\text { Dichloroethylene }\end{array}$ & 0.1 & 0.1 & Liver problems & $\begin{array}{l}\text { Discharge from industrial } \\
\text { chemical factories }\end{array}$ \\
\hline Dichloromethane & zero & 0.005 & $\begin{array}{l}\text { Liver problems; increased risk of } \\
\text { cancer }\end{array}$ & $\begin{array}{l}\text { Discharge from drug and } \\
\text { chemical factories }\end{array}$ \\
\hline 1,2-Dichloropropane & zero & 0.005 & Increased risk of cancer & $\begin{array}{l}\text { Discharge from industrial } \\
\text { chemical factories }\end{array}$ \\
\hline Di(2-ethylhexyl) adipate & 0.4 & 0.4 & $\begin{array}{l}\text { Weight loss, liver problems, or } \\
\text { possible reproductive difficulties. }\end{array}$ & $\begin{array}{l}\text { Discharge from chemical } \\
\text { factories }\end{array}$ \\
\hline Di(2-ethylhexyl) phthalate & zero & 0.006 & $\begin{array}{l}\text { Reproductive difficulties; liver } \\
\text { problems; increased risk of cancer }\end{array}$ & $\begin{array}{l}\text { Discharge from rubber and } \\
\text { chemical factories }\end{array}$ \\
\hline Dinoseb & 0.007 & 0.007 & Reproductive difficulties & $\begin{array}{l}\text { Runoff from herbicide used } \\
\text { on soybeans and } \\
\text { vegetables }\end{array}$ \\
\hline
\end{tabular}




\begin{tabular}{|c|c|c|c|c|}
\hline Dioxin $(2,3,7,8-\mathrm{TCDD})$ & zero & 0.00000003 & $\begin{array}{l}\text { Reproductive difficulties; increased } \\
\text { risk of cancer }\end{array}$ & $\begin{array}{l}\text { Emissions from waste } \\
\text { incineration and other } \\
\text { combustion; discharge } \\
\text { from chemical factories }\end{array}$ \\
\hline Diquat & 0.02 & 0.02 & Cataracts & Runoff from herbicide use \\
\hline Endothall & 0.1 & 0.1 & Stomach and intestinal problems & Runoff from herbicide use \\
\hline Endrin & 0.002 & 0.002 & Liver problems & $\begin{array}{l}\text { Residue of banned } \\
\text { insecticide }\end{array}$ \\
\hline Epichlorohydrin & zero & $T^{8}$ & $\begin{array}{l}\text { Increased cancer risk, and over a long } \\
\text { period of time, stomach problems }\end{array}$ & $\begin{array}{l}\text { Discharge from industrial } \\
\text { chemical factories; an } \\
\text { impurity of some water } \\
\text { treatment chemicals }\end{array}$ \\
\hline Ethylbenzene & 0.7 & 0.7 & Liver or kidneys problems & $\begin{array}{l}\text { Discharge from petroleum } \\
\text { refineries }\end{array}$ \\
\hline Ethylene dibromide & zero & 0.00005 & $\begin{array}{l}\text { Problems with liver, stomach, } \\
\text { reproductive system, or kidneys; } \\
\text { increased risk of cancer }\end{array}$ & $\begin{array}{l}\text { Discharge from petroleum } \\
\text { refineries }\end{array}$ \\
\hline Glyphosate & 0.7 & 0.7 & $\begin{array}{l}\text { Kidney problems; reproductive } \\
\text { difficulties }\end{array}$ & Runoff from herbicide use \\
\hline Heptachlor & zero & 0.0004 & Liver damage; increased risk of cancer & $\begin{array}{l}\text { Residue of banned } \\
\text { termiticide }\end{array}$ \\
\hline Heptachlor epoxide & zero & 0.0002 & Liver damage; increased risk of cancer & Breakdown of heptachlor \\
\hline Hexachlorobenzene & zero & 0.001 & $\begin{array}{l}\text { Liver or kidney problems; } \\
\text { reproductive difficulties; increased } \\
\text { risk of cancer }\end{array}$ & $\begin{array}{l}\text { Discharge from metal } \\
\text { refineries and agricultural } \\
\text { chemical factories }\end{array}$ \\
\hline Hexachlorocyclopentadiene & 0.05 & 0.05 & Kidney or stomach problems & $\begin{array}{l}\text { Discharge from chemical } \\
\text { factories }\end{array}$ \\
\hline Lindane & 0.0002 & 0.0002 & Liver or kidney problems & $\begin{array}{l}\text { Runoff/leaching from } \\
\text { insecticide used on cattle, } \\
\text { lumber, gardens }\end{array}$ \\
\hline
\end{tabular}




\begin{tabular}{|c|c|c|c|c|}
\hline Methoxychlor & 0.04 & 0.04 & Reproductive difficulties & $\begin{array}{l}\text { Runoff/leaching from } \\
\text { insecticide used on fruits, } \\
\text { vegetables, alfalfa, } \\
\text { livestock }\end{array}$ \\
\hline Oxamyl (Vydate) & 0.2 & 0.2 & Slight nervous system effects & $\begin{array}{l}\text { Runoff/leaching from } \\
\text { insecticide used on apples, } \\
\text { potatoes, and tomatoes }\end{array}$ \\
\hline $\begin{array}{l}\text { Polychlorinated biphenyls } \\
\text { (PCBs) }\end{array}$ & zero & 0.0005 & $\begin{array}{l}\text { Skin changes; thymus gland } \\
\text { problems; immune deficiencies; } \\
\text { reproductive or nervous system } \\
\text { difficulties; increased risk of cancer }\end{array}$ & $\begin{array}{l}\text { Runoff from landfills; } \\
\text { discharge of waste } \\
\text { chemicals }\end{array}$ \\
\hline Pentachlorophenol & zero & 0.001 & $\begin{array}{l}\text { Liver or kidney problems; increased } \\
\text { cancer risk }\end{array}$ & $\begin{array}{l}\text { Discharge from wood } \\
\text { preserving factories }\end{array}$ \\
\hline Picloram & 0.5 & 0.5 & Liver problems & Herbicide runoff \\
\hline Simazine & 0.004 & 0.004 & Problems with blood & Herbicide runoff \\
\hline Styrene & 0.1 & 0.1 & $\begin{array}{l}\text { Liver, kidney, or circulatory system } \\
\text { problems }\end{array}$ & $\begin{array}{l}\text { Discharge from rubber and } \\
\text { plastic factories; leaching } \\
\text { from landfills }\end{array}$ \\
\hline Tetrachloroethylene & zero & 0.005 & $\begin{array}{l}\text { Liver problems; increased risk of } \\
\text { cancer }\end{array}$ & $\begin{array}{l}\text { Discharge from factories } \\
\text { and dry cleaners }\end{array}$ \\
\hline Toluene & 1 & 1 & $\begin{array}{l}\text { Nervous system, kidney, or liver } \\
\text { problems }\end{array}$ & $\begin{array}{l}\text { Discharge from petroleum } \\
\text { factories }\end{array}$ \\
\hline Toxaphene & zero & 0.003 & $\begin{array}{l}\text { Kidney, liver, or thyroid problems; } \\
\text { increased risk of cancer }\end{array}$ & $\begin{array}{l}\text { Runoff/leaching from } \\
\text { insecticide used on cotton } \\
\text { and cattle }\end{array}$ \\
\hline 2,4,5-TP (Silvex) & 0.05 & 0.05 & Liver problems & $\begin{array}{l}\text { Residue of banned } \\
\text { herbicide }\end{array}$ \\
\hline 1,2,4-Trichlorobenzene & 0.07 & 0.07 & Changes in adrenal glands & $\begin{array}{l}\text { Discharge from textile } \\
\text { finishing factories }\end{array}$ \\
\hline
\end{tabular}




\begin{tabular}{|l|l|l|l|l|}
\hline $1,1,1$-Trichloroethane & 0.20 & 0.2 & $\begin{array}{l}\text { Liver, nervous system, or circulatory } \\
\text { problems }\end{array}$ & $\begin{array}{l}\text { Discharge from metal } \\
\text { degreasing sites and other } \\
\text { factories }\end{array}$ \\
\hline Trichlo-Trichloroethane & 0.003 & 0.005 & $\begin{array}{l}\text { Liver, kidney, or immune system } \\
\text { problems }\end{array}$ & $\begin{array}{l}\text { Discharge from industrial } \\
\text { chemical factories }\end{array}$ \\
\hline Vinyl chloride & zero & 0.005 & $\begin{array}{l}\text { Liver problems; increased risk of } \\
\text { cancer }\end{array}$ & $\begin{array}{l}\text { Discharge from metal } \\
\text { degreasing sites and other } \\
\text { factories }\end{array}$ \\
\hline Xylenes (total) & zero & 0.002 & Increased risk of cancer & $\begin{array}{l}\text { Leaching from PVC pipes; } \\
\text { discharge from plastic } \\
\text { factories }\end{array}$ \\
\hline & 10 & 10 & Nervous system damage & $\begin{array}{l}\text { Discharge from petroleum } \\
\text { factories; discharge from } \\
\text { chemical factories }\end{array}$ \\
\hline
\end{tabular}

\begin{tabular}{|c|c|c|c|c|}
\hline \multicolumn{5}{|l|}{ Radionuclides } \\
\hline Contaminant & $\begin{array}{l}\mathrm{MCLG}^{1} \\
(\mathrm{MG} / \mathrm{L})^{2}\end{array}$ & $\begin{array}{l}\text { MCL or } \\
\pi^{1} \\
(M G / L)^{2}\end{array}$ & $\begin{array}{l}\text { Potential Health Effects from } \\
\text { Long-Term Exposure Above the } \\
\text { MCL (unless specified as short- } \\
\text { term) }\end{array}$ & Sources of Contaminant in Drinking Water \\
\hline $\begin{array}{l}\text { Alpha } \\
\text { particles }\end{array}$ & $\begin{array}{l}\text { none }^{7} \\
----- \\
--- \\
\text { zero }\end{array}$ & $\begin{array}{l}15 \\
\text { picocuries } \\
\text { per Liter } \\
(\mathrm{PCl} / \mathrm{L})\end{array}$ & Increased risk of cancer & $\begin{array}{l}\text { Erosion of natural deposits of certain } \\
\text { minerals that are radioactive and may emit a } \\
\text { form of radiation known as alpha radiation }\end{array}$ \\
\hline $\begin{array}{l}\text { Beta particles } \\
\text { and photon } \\
\text { emitters }\end{array}$ & $\begin{array}{l}\text { none }^{7} \\
---- \\
--- \\
\text { zero }\end{array}$ & $\begin{array}{l}4 \\
\text { millirems } \\
\text { per year }\end{array}$ & Increased risk of cancer & $\begin{array}{l}\text { Decay of natural and man-made deposits of } \\
\text { certain minerals that are radioactive and } \\
\text { may emit forms of radiation known as } \\
\text { photons and beta radiation }\end{array}$ \\
\hline $\begin{array}{l}\text { Radium } 226 \\
\text { and Radium } \\
228 \\
\text { (combined) }\end{array}$ & $\begin{array}{l}\text { none }^{7} \\
----- \\
--- \\
\text { zero }\end{array}$ & $5 \mathrm{PCl} / \mathrm{L}$ & Increased risk of cancer & Erosion of natural deposits \\
\hline Uranium & zero & $\begin{array}{l}30 \mathrm{UC} / \mathrm{L} \\
\text { as of } \\
12 / 08 / 03\end{array}$ & $\begin{array}{l}\text { Increased risk of cancer, kidney } \\
\text { toxicity }\end{array}$ & Erosion of natural deposits \\
\hline
\end{tabular}




\section{Notes}

Definitions:

- Maximum Contaminant Level Goal (MCLG) - The level of a contaminant in drinking water below which there is no known or expected risk to health. MCLGs allow for a margin of safety and are non-enforceable public health goals.

- Maximum Contaminant Level (MCL) - The highest level of a contaminant that is allowed in drinking water. MCLs are set as close to MCLGs as feasible using the best available treatment technology and taking cost into consideration. MCLs are enforceable standards.

- Maximum Residual Disinfectant Level Goal (MRDLG) - The level of a drinking water disinfectant below which there is no known or expected risk to health. MRDLGs do not reflect the benefits of the use of disinfectants to control microbial contaminants.)

- Treatment Technique (TT) - A required process intended to reduce the level of a contaminant in drinking water.

- Maximum Residual Disinfectant Level (MRDL) - The highest level of a disinfectant allowed in drinking water. There is convincing evidence that addition of a disinfectant is necessary for control of microbial contaminants.

- Units are in milligrams per liter (MC/L) unless otherwise noted. Milligrams per liter are equivalent to parts per million (PPM).

3 EPA's surface water treatment rules require systems using surface water or ground water under the direct influence of surface water to

(1) disinfect their water, and

(2) filter their water or

meet criteria for avoiding filtration so that the following contaminants are controlled at the following levels:

- Cryptosporidium: Unfiltered systems are required to include Cryptosporidium in their existing watershed control provisions

- Giardia lamblia. $99.9 \%$ removal/inactivation.

- Viruses: $99.99 \% \mathrm{removal} /$ inactivation.

- Legione/la: No limit, but EPA believes that if Giardia and viruses are removed/inactivated, according to the treatment techniques in the Surface Water Treatment Rule, Legionel/a will also be controlled.

- Turbidity: For systems that use conventional or direct filtration, at no time can turbidity (cloudiness of water) go higher than 1 Nephelometric Turbidity Unit (NTU), and samples for turbidity must be less than or equal to 0.3 NTUs in at least 95 percent of the samples in any month. Systems that use filtration other than the conventional or direct filtration must follow state limits, which must include turbidity at no time exceeding 5 NTUs.

- Heterotrophic Plate Count (HPC): No more than 500 bacterial colonies per milliliter.

- Long Term 1 Enhanced Surface Water Treatment: Surface water systems or groundwater under the direct influence (GWUDI) systems serving fewer than 10,000 people must comply with the applicable Long Term 1 Enhanced Surface Water Treatment Rule provisions (such as turbidity standards, individual filter monitoring, Cryptosporidium removal requirements, updated watershed control requirements for unfiltered systems).

- Long Term 2 Enhanced Surface Water Treatment Rule: This rule applies to all surface water systems or ground water systems under the direct influence of surface water. The rule targets additional Cryptosporidium treatment requirements for higher risk systems and includes provisions to reduce risks from uncovered finished water storage facilities and to ensure that the systems maintain microbial protection as they take steps to reduce the formation of disinfection byproducts.

- Filter Backwash Recycling: The Filter Backwash Recycling Rule requires systems that recycle to return specific recycle flows through all processes of the system's existing conventional or direct filtration system or at an alternate location approved by the state. 
${ }^{4}$ No more than $5.0 \%$ samples total coliform-positive (TC-Positive) in a month. (For water systems that collect fewer than 40 routine samples per month, no more than one sample can be total coliform-positive per month.) Every sample that has total coliform must be analyzed for either fecal coliforms or $E$. coli if two consecutive TCpositive samples, and one is also positive for E.coli fecal coliforms, system has an acute MCL violation.

Fecal coliform and E. coli are bacteria whose presence indicates that the water may be contaminated with human or animal wastes. Disease-causing microbes (pathogens) in these wastes can cause diarrhea, cramps, nausea, headaches, or other symptoms. These pathogens may pose a special health risk for infants, young children, and people with severely compromised immune systems.

Although there is no collective MCLG for this contaminant group, there are individual MCLGs for some of the individual contaminants:

- Trihalomethanes: bromodichloromethane (zero); bromoform (zero); dibromochloromethane (0.06 MC/L): chloroform $(0.07 \mathrm{MG} / \mathrm{L}$.

- Haloacetic acids: dichloroacetic acid (zero); trichloroacetic acid (0.02 Mc/L); monochloroacetic acid (0.07 MC/L). Bromoacetic acid and dibromoacetic acid are regulated with this group but have no MCLGs.

Lead and copper are regulated by a treatment technique that requires systems to control the corrosiveness of their water. If more than $10 \%$ of tap water samples exceed the action level, water systems must take additional steps. For copper, the action level is $1.3 \mathrm{Mc} / \mathrm{L}$, and for lead is $0.015 \mathrm{MC} / \mathrm{L}$.

8

Each water system must certify, in writing, to the state (using third-party or manufacturer's certification) that when acrylamide and epichlorohydrin are used to treat water, the combination (or product) of dose and monomer level does not exceed the levels specified, as follows:

- Acrylamide $=0.05 \%$ dosed at $1 \mathrm{MC} / \mathrm{L}$ (or equivalent)

- Epichlorohydrin $=0.01 \%$ dosed at $20 \mathrm{mG} / \mathrm{L}$ (or equivalent) 